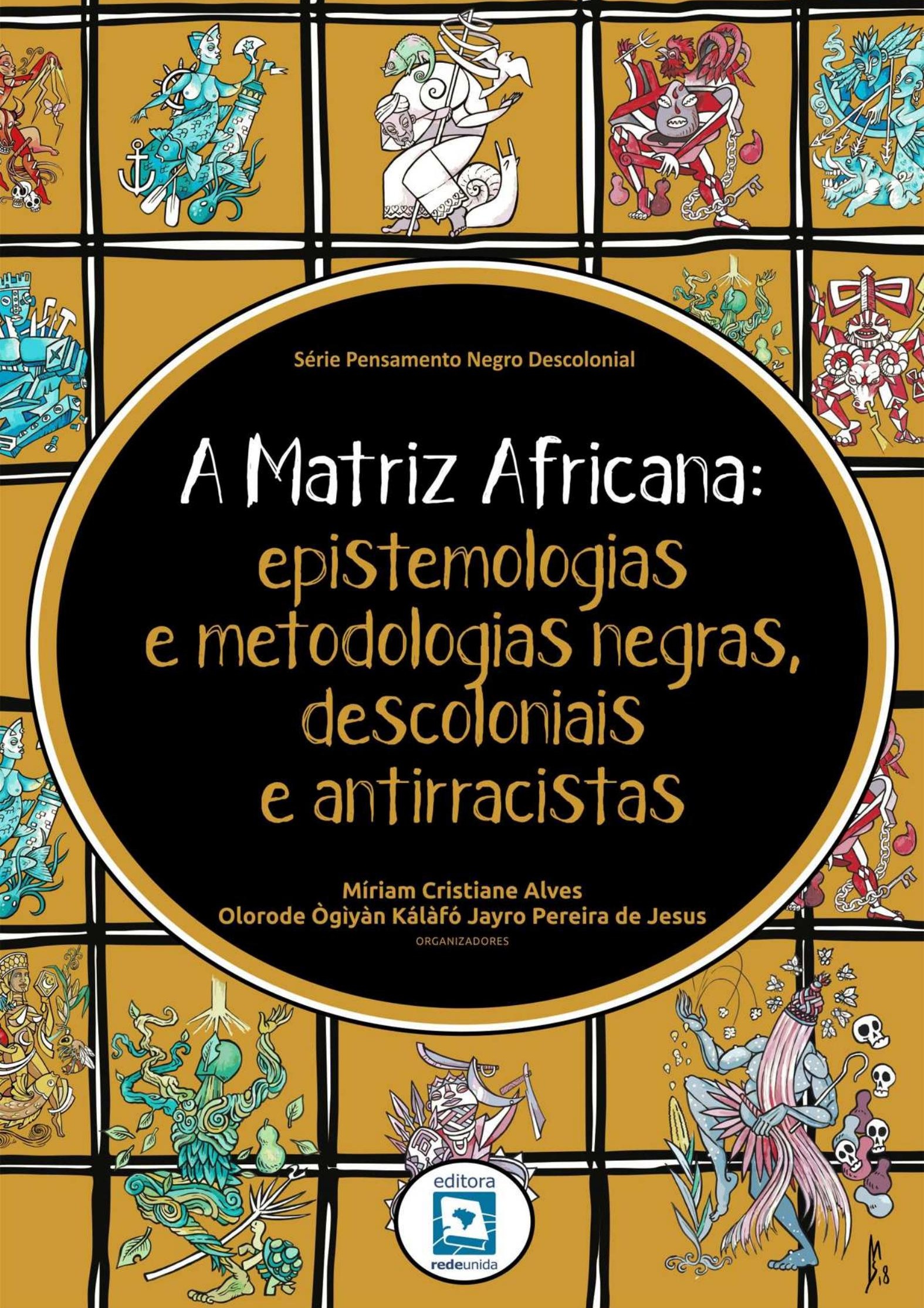




\section{A Matriz Africana: epistemologias e metodologias negras, descoloniais e antirracistas}

www.redeunida.org.br

Volume 2 
Copyright $\odot 2020$ by Associação Brasileira da Rede UNIDA

Coordenador Nacional da Rede UNIDA

Túlio Batista Franco

Coordenação Editoria

Editor-Chefe: Alcindo Antônio Ferla

Editores Associados: Gabriel Calazans Baptista, Ricardo Burg Ceccim, Cristian Fabiano Guimarães, Márcia Fernanda Mello Mendes, Júlio César Schweickardt, Sônia Lemos, Fabiana Mânica Martins.

Conselho Editorial

Adriane Pires Batiston - Universidade Federal de Mato Grosso do Sul, Brasil. Alcindo Antônio Ferla - Universidade Federal do Rio Grande do Sul, Brasil. Àngel Martínez-Hernáez - Universitat Rovira i Virgili, Ardigó Martino - Università di Bologna, Itália, Ialia. Paz Lorido - Universitat de les Illes Balears, Espanha. Celia Beatriz Iriart - University of New Mexico, Estados Unidos da América. Denise Bueno - Universidade Federal do Rio Grande do Sul, Brasil. Emerson Elias Merhy - Universidade Federal do Rio de Janeiro, Brasil. Erica Rosalba Mallmann Duarte - Universidade Federal do Rio Grande do Sul, Brasil. Francisca Valda Silva de Oliveira - Universidade Federal do Rio Grande do Norte, Brasil. Izabella Barison Matos - Universidade Federal da Fronteira Sul, Brasil. Hêider Aurélio Pinto João Henrique Lara do Amaral - Universidade Federal de Minas Gerais, Brasil. Júlio César Schweickard - Fundação Oswaldo Cruz/Amazonas, Brasil. Laura Camargo Macruz Feuerwerker - Universidade de São Paulo, Brasil. Laura Serrant-Green - University of Wolverhampton, Inglaterra. Leonardo Federico Universidad Nacional de Lanús, Argentina. Lisiane Böer Possa - Universidade Federal de Santa Maria, Brasil. Liliana Santos - Universidade Federal da Bahia, Brasil. Pará́ba Brasil. Mara Lisiane dos Santos - Universidade Federal de Mato Grosso do Sul, Brasil. Márcia Regina Cardoso Torres - Secretaria Municipal de Saúde do Rio de Janeiro, Brasil. Marco Akerman - Universidade de São Paulo, Brasil. Maria Luiza Jaeger - Associação Brasileira da Rede UNIDA, Brasil. Maria Rocineide Ferreira da Silva - Universidade Estadual do Ceará, Brasil. Paulo de Tarso Ribeiro de Oliveira - Universidade Federa do Pará, Brasil. Ricardo Burg Ceccim - Universidade Federal do Rio Grande do sul, Brasil. Rodrigo Tobias de Sol Ra Lima Stavie Baduy - Universidade Estadual de Londrina Brasil. Simone Edi Chaves - Ideia e Método, Brasil. Sueli Terezinha Goi Barrios - Ministério da Saúde, Brasil. Túlio Batista Franco - Universidade Federal Fluminense, Brasil. Vanderléia Laodete Pulga Universidade Federal da Fronteira Sul, Brasil. Vera Lucia Kodjaoglanian - Fundação Oswaldo Cruz/Pantanal, Brade UNIDA Brasil.
A Série Pensamento Negro Descolonial apresenta produçôes autorais com narrativas de intelectuais, em sua maioria de pesquisadoras/es negra/os, tendo como centralidade a insurgência de epistemologia e metodologias negras no campo das ciências humanas e da saúde. Busca em torno de um eixo, o antirracismo, cujos deslocamentos, desdobramentos e agenciamentos epistêmicos têm o intuito de estimular reflexões sobre nossos usos e interpretações de matrizes do pensamento negro, assim como sobre a necessidade de formação de novas redes intelectuais na produção do conhecimento. Assinalamos o caráte político de tal escolha (o antirracismo como nossa em distintos níve como uma prenissa a congrega Pensamento Negros Descolonial: o lugar de epistemologias e metodologias negras $\mathrm{m}$ nossas produções e difusões de conhecimento.

Coordenação da Série

Míriam Cristiane Alves
Comissão Executiva Editorial

Gabriel Calazans Baptista

Márcia Regina Cardoso Torres

Arte Capa | Projeto Gráfico | Diagramação

Lucia Pouchain

Ilustrações

Bolivar Marin

DADOS INTERNACIONAIS DE CATALOGACCÃO NA PUBLICAČ̃̃-CIP

A474m Alves, Míriam Cristiane (org.)

A Matriz Africana: Epistemologias e Metodologias Negras, Descoloniais e Antirracistas / Organizadores: Míriam Cristiane Alves e Olorode Ògiyàn Kálàfó Jayro Pereira de Jesus - - 1. ed. Porto Alegre : Rede Unida, 2020

p. il.; (Série Pensamento Negro Descolonial, v.2).

E-book: $5.23 \mathrm{Mb}$; PDF

Inclui bibliografia

SBN: 978-65-87180-32-8

DOI: $10.18310 / 9786587180328$

1. Colonialismo. 2. Comportamento e Mecanismos Comportamentais. 3. Fatores Raciais. 4. Grupo com Ancestrais do Continente Africano. I. Título. II. Assunto. III. Organizadores.

$21-30180029$

CDD 305.56:960.981 CDU $342.724(6)(81)$

INDICE PARA CATALOGO SISTEMATICO

1. Grupos sociais e questões raciais; História da África; História do Brasil.

2. Minorias étnicas e Igualdade racial; Brasil; África

Catalogação elaborada pelo bibliotecário Pedro Anizio Gomes CRB-8 8846

Todos os direitos desta edição reservados à Associação Brasileira Rede UNIDA Rua São Manoel, no 498 - CEP 90620-110, Porto Alegre - RS. Fone: (51) 3391-1252

\section{www.redeunida.org.br}

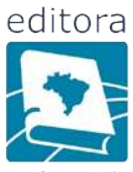




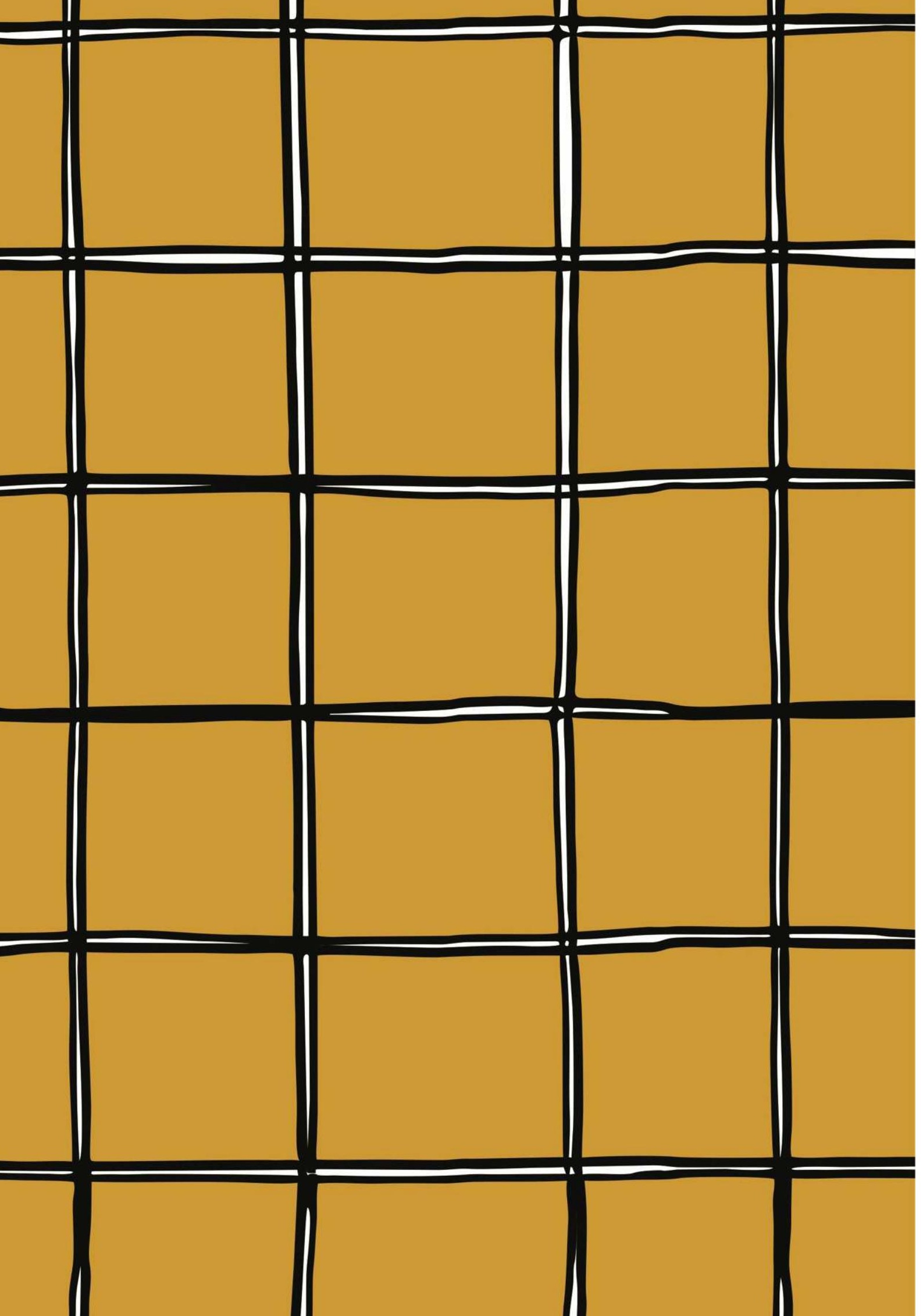

ÉṢÙ ... 7

PREFÁCIO

Kaká Portilho

ÒGÚN

APRESENTAÇ̃̃O.

Olorode Ògiyán Kálàfó Jayro Pereira de Jesus e Míriam Cristiane Alves

YÁNSÀN-OYA

DISCURSIVIDADES AMOROSAS: AGENCIAMENTOS ÉTICOS AFRICANOS E DESCOLONIAIS

Monique Navarro e Míriam Cristiane Alves

ȘÀNGÓ. .. .42

AFROTEOLOGIA DO ORÒ

Hendrix Silveira

ODE E OTIN .. .70

REFLEXÕES SOBRE A FALSA UNIVERSALIDADE DA TEOLOGIA JUDAICOCRISTÃ: EPISTEMICÍDIO E A CONSTRUÇÃO DO “OUTRO”.................................72 Valéria Fernandes de Carvalho

$O B A ̀$

PADÊ DE EXÚ ABOLICIONISTA: INSURGÊNCIA NEGRA POR UM ABOLICIONISMO PENAL AFRODIASPÓRICO …………………………………….....90 Luciano Góes 


$$
\text { És } \grave{u}^{1}
$$

\section{Éșù! Senhor da existência.}

$$
\text { Pai-ancestre, }
$$

representaç̃o coletiva de todos os Éșù individuais.

Que na dinâmica social e cosmológica negro-africana

tem a prerrogativa da circulação de àșe que dinamiza o ciclo vital da existência.

$$
\text { Senhor da ordem cosmológica }
$$

toda ação e movimento depende de sua atuação, Éşù. Aquele que está atento à produção de vida

é responsável pela interação de princípios masculinos e femininos.

É aquele que cuida das vias de circulação do interior do corpo, suas cavidades - Éșù Bara.

Aquele que introjeta substâncias necessárias

ao desenvolvimento do feto, do Orí. Ligado à placenta,

Éșù, é aquele que realiza o processo capaz de engendrar a passagem e o nascimento

de um ser do Örun para o Àiyé e vice-versa.

òkòtó, multiplicação e crescimento! Senhor dos ẹbo,

pois é o encarregado e transportador de oferendas. Senhor do erù (carrego)

pois é ele quem mobiliza o Cosmos

para possibilitar as manifestações das divindades e manter a harmonia do Cosmos.

Éșù, aquele que é intérprete e explicitador de mensagens do oráculo divinatório.
Laroyê. Caminhos complementares integrativos e interconectados, abertos! Nos cruzos da encruza (re) encontro escrevivências bioafroancestrálicas de existencialidades comunais. 0 mensageiro que por vezes, macho e outras fêmea, se apresenta nas narrativas que compõem a Série Pensamento Negro Descolonial: Epistemologias e Metodologias Negras, Descoloniais e Antirracistas. Partindo de dentro da academia - locus de enunciação da ideologia genocida proposta na suposição de superioridade de uma etnia recente e minoritária, sobre todas as outras; e de uma das cidades que fazem parte do conglomerado sul do Brasil, por seu histórico-local de concentração de muitos imigrantes oriundos das políticas de branqueamento no país; este pode ser considerado um trabalho pioneiro e desafiador, pois (re)estabelece a comunicação integralista: escrita, emoção, encantaria, ritual, ressonante em múltiplas vozes que se fundem num grito estridente e desestabilizador da pretensiosa tentativa de absolutização de uma "verdade universal", gerada na incubadora fálico-patriarcalista-ocidentalizada-brasileira.

Os caminhos traçados nas encruzilhadas da pluralidade afroepistemológica, reequacionados na experiência diaspórico-brasileira, nos reconduz "para dentro", ao ventre das multilogias ulterinas de nossa(s) matriz(es), advinda(s) do continente africano.

Com a comunicação estabelecida, abrem-se os portais de (re)conexão com o Todo, o Cosmo, a Mãe, cocriadora do multiverso, sem nunca ter deixado de lado seu par complementar. A outra metade da cabaça trina da existência divina.

No livro, uma viagem, mergulho profundo à diversas formas de existir no mundo, incluindo a nossa, a matriarcal. Os textos seguem uma espécie de caminhada de retorno "A Casa da Minha Mãe", a África mitontológica, impulsionadora das sobrevivências, e ancestralicamente, ventre nutridor de nossas existencialidades, reorientadas para "ser o que nos impossibilitam ser", ou apenas, as tentativas de nos impossibilitar ser, todavia, sem êxito absoluto.

Cada página em suas dolorosas e profundas fissuras, desvendam enganos, subliminaridades, materializações democraticamente racializadas, dissimulações neocoloniais, legitimadas nos mecanismos de poder, estruturantes da racista 
sociedade brasileira. 0 descortinar evidencia domínios, antes imperceptíveis à alienação, doença pandêmica que acomete a população negra mundial.

Serpenteada no infinito círculo de início, meio e início, meu/nosso multiverso cognitivo, aliado à minha/nossa genealogia cósmica e ancestral, materializa a cena e eleva às narinas o perfume das ervas, quinadas no coração, a pedra fundamental onde o sangue é espargido. Os autores ritualizam e nos oferecem potência ao ligare por meio do sangue verde das ervas. Ao ler cada trecho, um banho cristaliniza nossos mecanismos sensoriais. Quinadas pelas mãos que nos escrevem, a pulsão do verde intenso evoca vida, não sobrevivência. Hálitos divinamente sankofaquiniano, unificando neste livro, o Egbé (comunidade física, ancestral e cósmica), oracularmente reunido, para continuar o processo da cura. Agonizantes, percebemos que nunca fomos abandonados aos envenenamentos sutis da socialização primária, reforçados pelos mecanismos secundários de socialização.

Neste ritual, o banho antecede as benzeduras contra o mau-olhado dos que invejam a riqueza material e imaterial das melano-existencialidades. Daí em diante, incorporando a malemolência elegante de malandros; as contagiantes gargalhadas do "povo de rua"; os escritos (des)ordenam espacialidades, cortando como punhais as demandas da ideologia racial, abrindo o caminho aos encantados que manifestam suas vozes das profundezas da Mãe-Terra - onde rios, mares, raízes, rizomas, depositam suas memórias cosmoancestrais - e nos trazem as mensagens aqui contidas.

Mensagens que vibram no vermelho da emoção e da força de realização, representado pelo sangue afropindorâmico vertido no chão onde se ergueram os pilares de uma nação feita por povos melanodérmicos, mas para o bem-estar de povos despiguimentados. Tal expiação, retorna pelo princípio matriarcal da troca, ou da reciprocidade. 0 líquido sanguíneo afropindorâmico, que regou e rega a Terra, retornado, implode - nos escritos aqui narrados - os "pilares" falseados, fabricadas no próprio veneno que os indo-europeus-norte-americanos tentaram usar para nos aniquilar. Com pilares abalados, os portais cognitivos se abrem e as brilhantes sistematizações afrontomitoepistemilógicas narradas na primeira e na terceira pessoa, do Eu ao Nós, sintonia mutuamente cooperativa, suleada pelos valores civilizatórios africanos, legados pela nossa ancestralidade.

Proliferam-se e prosperam conceitos emergidos das fissuras e nutridos no ventre ancestral. Tais conceitos vibram como ventos de Oya, movimentado a emoção racionalmente físico-cósmica do segundo volume da Série Pensamento Negro Descolonial - A Matriz Africana: Epistemologias e Metodologias Negras, Descoloniais e Antirracistas -, sobrepondo às lentes da ocidentologia. 0 que necessariamente amplia a pluralidade de valores civilizatórios baseados no bem-estar da comunidade e não no indivíduo, unicamente.

Cada coautor traz, intrínseco, valores civilizatórios bioafroancestrálicos matriarcais. Um deles, a complementariedade, implode paradigmas embutidos nas tramas acadêmico-institucionais, que capturam e internalizam verdades cristalizadas. Transitando, simultaneamente, em dois planos dimensionais distintos, integrados e complementares, as percepções sensitivas das autoras e dos autores, ultrapassam as fronteiras da cosmovisão. E materializam em suas escrevivências, nossas próprias experiências afroexistenciais. Dos dois mundos, "suas vozes" nos refazem em Orí. Indivíduos não individualizados, mas comunais, fenomenalmente ubuntu. Comunidade sociocentrada, ressignificada no processo árduo e doloroso da reontologização bioafroancestrálica, disseminado desde a década de 80 pelo Projeto Tradição dos Orixás, partindo de um dos mestres coautores desta obra, Olorode Jayro de Jesus. Precedido por muitos movimentadores da emancipação, e sucedido, por aqueles que formam e formarão um continnum Circulo Ininterrupto. Voraz como um búfalo e serpenteador como a Kundalini, Besen, Òsùmàrè, nossa serpente cósmica nutridora de tais descobertas.

Em cada linha dos textos sentimos a repetição do ato cósmico cadenciado ritmicamente na circularidade temporal onde realiza-se presente, passado e futuro numa mesma espacialidade/temporalidade. Segredos inteligíveis aos originários da experiência matricêntrica, uterocêntrica, matripontemente, força realizadora do ato aquilombar, verbo materializado nas concretudes belamente apresentadas nas linhas e entrelinhas, das benzeduras às encantarias, do candomblé ao batuque, dos cruzos de norte ao sul do Brasil. Vivências pulsantes nos orientam no caminho do nosso cosmo-afroexistencializador de nós por, e para nós.

Profícuas problematizações dos conceitos e categorias solidificadas nos imaginários sociopolíticos ocidentalizados que propõem: a) uma revisão e apreensão de antigos conceitos para dentro de uma experiência civilizatória africano-diaspórica. o que amplia possibilidades pluriversais de investigação científica; b) a criação e sistematização de "novos conceitos" baseados emantigas experiências afropindorâmicas; 
c) o reconhecimento das mitologias africanas como formas bioafroacentrálica de existencialidades no mundo material, e para além dele.

Um livro necessário, urgente que nos serve um banquete - na grande roda de celebração da vida - oportunizando a re-existência, ancorada na memória coletiva ancestral, evocada na tessitura dos cruzos textuais.

Ah, o amor! Questões como a natureza e as formas de experienciar o amor. Da ideologia do desejo objetificante e separatista de Platão, aos modos de relacionalidades poli-comunais que divide responsabilidades das relações. Amores que intimamente reconhecem o divino em tudo, saudáveis para o bem-estar das relações sociais e ampliação da energia curadora de tudo à nossa volta. Ou o amor idealista, criteriosamente negacionista das vibrações do corpo, à conquistar a conduta purificada, demonstração de domínio próprio, negação e o redirecionamento do desejo. 0 amor como valor sublime supremamente separado do corpo. 0 paradoxo do amor, em perspectivas individualizada e coletiva a apresentar a negação da corporeidade, da emoção, do instinto e da intuição. A objetificação e o distanciamento da Natureza, para a superioridade do eu idealizado na perfeição evolucionista.

Reinscrevendo sentidos da teologia apropriada pelo cristianismo incorporando a exunêutica, na análise; colocando em xeque o abolicionismo, a (in) justiça brasileira; e estreitando, por vezes aniquilando as fronteiras entre a racionalidade e os mecanismos sensoriais... interrupção brusca no continuo e mais perverso Holocausto Maáfico de todos os tempos: genocídios, epistemicídios, menticídios, semiocídio... que em comum tem o alvo, o corpo negro.

Nos giros onde o início é o meio e o meio é o início, a organicidade do saber que constitui minha afropindorâmico existencialidade, move a gratidão pelo convite para prefaciar a presente obra e reforçar o êxtase do encontro de tão belas e encantadas vozes que ecoam no âmago da minha coletividade, pulsando o reencontrar de antigas e atuais experienciais, repetidas em cada linha. Evocando um protagonismo que vem de dentro, o mergulho uterino na placenta ancestrálica, alimentada astrofísica e metafisicamente, com magia encantada das mais belas vozes reais que são apresentadas neste espaço de afro existencialidades, tornando-me intimamente ligada a tudo que aqui me reconecta ao sentido primordial da relação comunitária que vivencio desde o momento que meu Orí foi parido pela vagina da deusa que possibilitou meu retorno ao Ayé.
Que este seja o segundo de muitos outros livros desta série reontologizante que vem de encontro aos nossos anseios, provocados pela repressão genocida e holocáustica, tão nociva a nossa cosmo-afroexistencializção. Sinto aqui o particularismo provinciano europeu e suas redes influenciadas por sua matriz civilizatória, se esvaindo de sentido e de certeza, pois os portais adentram o mundo, ou os mundos pluriversais aqui expostos. A restituição organizada e sistematizada de saberes ancestrais e tradicionais, e seus modos operativos nos faz viajar pelo mundo africano e diaspórico, geográfico e principalmente, aquela parte conectada ao espírito cósmico que está enraizada no nosso cotidiano.

Ogum Yiê!

Okê Arô!

Atotô!

Ewe oo!

Aroboboy!

Kaô Kabiecile!

Saluba!

Ora Iyê Iyê oo!

Obá Siré!

Ri Ro Yewa!

Eparey Oyá!

Loci loci Logun!

Ayrá Lê !

Odoya!

Epao, èpa Bàbá! 


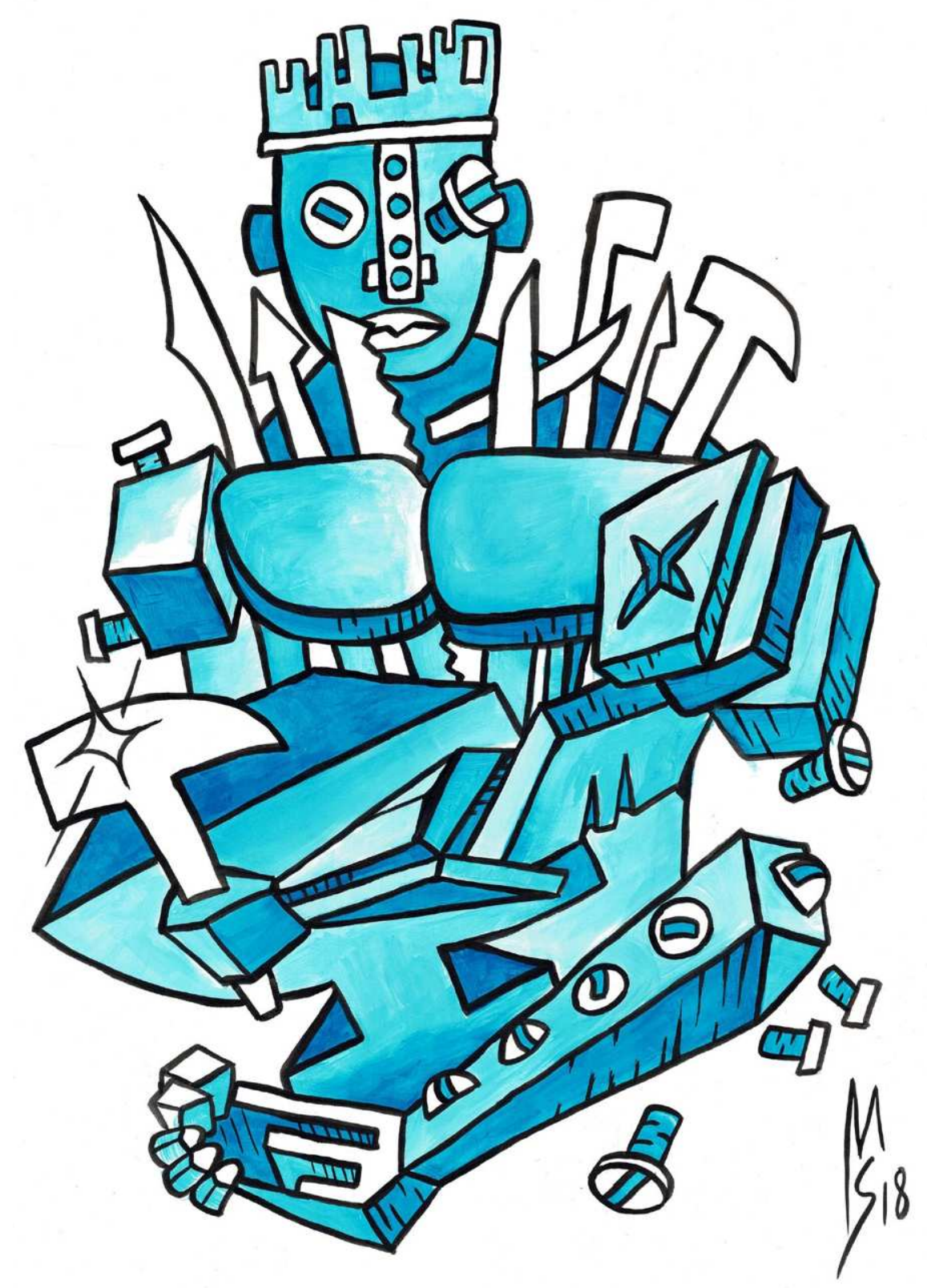

\section{Ògún ${ }^{2}$}

Ògún! Aquele que abre os caminhos para a civilização. Òrișà Asiwajú - aquele que toma a vanguarda, que vai à frente,

abrindo os caminhos em prol da coletividade.

Ògún - o desbravador

Está ligado ao princípio físico químico e fenomenológico do ferro.

- Ele caracteriza a passagem da civilização da pedra

para a civilização dos metais.

Outrora, se fez destemido caçador e conhecedor do segredo das folhas. Agora, é ferreiro e soldado.

Senhor da tecnologia,

do transporte,

da mineralogia

da agricultura.

Dono de dois facões,

com um colhe a horta

com o outro abre os caminhos.

Na diáspora, tem sua prerrogativa mítico-social ressignificada assumindo o papel de estrategista e guerreiro

com importante presença nas mudanças sociais, políticas e tecnológicas. Ogún, aquele que desacomoda e, incessantemente,

luta pelo bem comum, pela justiça social.

2 Oríkì (louvação) para Ògún, construído a partir das obras: "Agadá: dinâmica da civilização africano-brasileira", de Marco Aurélio Luz (2000), "Os Nàgô e a Morte: Pàde, Asèsè e o culto Égun na Bahia", de Juana Elbein dos Santos (2012); e “Dicionário yorubá-português”, de José Beniste (2011). 
APRESENTAÇÃO ${ }^{3}$

Olorode Ògìyán Kálàfó Jayro Pereira de Jesus Míriam Cristiane Alves

“[...] a diversidade do mundo é inesgotável [...] e essa diversidade continua desprovida de uma epistemologia adequada. [...], a diversidade do mundo continua por construir" (SANTOS, 2010, p. 51).

Este segundo volume da Série Pensamento Negro Descolonial, "A Matriz Africana - Epistemologias e Metodologias Negras, Descolonial e Antirracistas", está carregado de questões-vida que emergiram e emergem em nossa caminhada, enquanto afroativistas, intelectuais, pesquisador e pesquisadora na e da diáspora africana no Brasil. Com foco na Matriz Africana, esse volume se reveste de incomensurável importância, residindo na tarefa de concretizá-lo a explicitação de saberes dialógicos com os demais conhecimentos civilizacionais edificadores da sociedade brasileira. Para que vocês, leitora e leitor, nos acompanhem no ideário deste volume, explicitaremos alguns elementos de nossa caminhada, na perspectiva de compartilhar os motivos pelos quais focamos na Matriz Africana.

No contexto da Cosmo-Afroexistencialização e condição bioafroancestrálica de ser-existir, inerente às/aos africanas/os e afrodescendentes dispersados pela "migração forçada" (SODRÉ, 2017, p. 90), tivemos a possibilidade de vivenciar um conjunto de experiências que nos subsidiaram na organização desse volume.

Uma experiência de grande relevo para mim, Olorode Ògìyán Kálàfó Jayro Pereira de Jesus, foi integrar um coletivo formado por mulheres e homens de correlata afroancestralidade, com os quais tive um proeminente afroativismo na década de 1980, através do Instituto de Pesquisas e Estudos da Língua e Cultura Yorubá (IPELCY). Naquela ocasião, realizamos uma ação inovadora e de impacto social junto às comunidades-terreiros, inicialmente da Baixada Fluminense, 3 Essa coletânea tem apoio do Departamento de Apoio à Gestão Participativa e ao Controle Social da Secretaria de Gestão Estratégica e Participativa do Ministério da Saúde (DAGEP/SGEP/MS), por meio do projeto RENAFRO Saúde e da interiorização da Política Nacional de Saúde Integral da População Negra (PNSIPN): programa de capacitação afrocentrada, do curso de Psicologia, da Faculdade de Medicina, da Universidade Federal de Pelotas (UFPel); bem como, do Programa de Apoio à Pós-Graduação da Coordenação de Aperfeiçoamento Psicologia Social e Institucional da Universidade Federal do Rio Grande do Sul (PPGPSI-UFRGS).
Estado do Rio de Janeiro, mediante uma política verdadeiramente "contra colonial" (SANTOS, 2019, p. 19).

Na contralógica do "racismo colonial" (HENRIQUE, 2016, p.15), o IPELCY desencadeou, na Baixada Fluminense, todo um processo seminal de dialogia acerca da "colonização e contra colonização" (SANTOS, 2019, p. 19), encetando uma luta verdadeira contra "o racismo cultural religioso" (JESUS, 2003). Na ocasião, foram produzidas ações de mobilização e articulação dos espaços de realizações de cultos afros e seus vivenciadores/ as, atuando também no campo jurídico de criminalização da intolerância religiosa, na perspectiva dos direitos humanos. Já naquele momento o empenho se voltava para o que entendíamos como afroepistemologia, reiterando-a, por compreender o modo como nós, povo de pertencimento afroancestrálico, nos constituímos em agentes da exacerbação dos pressupostos conceituais afroepistemológicos civilizacionais da Matriz Africana em meio à sociedade abrangente. Já exacerbávamos apologeticamente um arsenal afroaxiológico que singulariza o projeto, sobretudo, junto aos meios de comunicação.

O projeto "Tradição dos Orixás" (GOMES; OLIVEIRA, 2019), como foi inicialmente denominado, expandiu-se por quase todo o país, encetando, por conseguinte, um movimento nacional contra o "racismo religioso" (DEUS, 2019), perpetrado desta feita pelas igrejas do campo neopentecostal, que volumosamente continuam crescendo e se expandindo Brasil afora, numa estratégia georeferencial de desestabilização de territórios afroancestrálicos.

Importa denotar que o projeto acima referido se desencadeou em face da dinâmica de "resistência ativa, política e epistemológica" (SANTOS, 2010, p. 49), consubstanciado nos seus primórdios pelas e com as narrativas afroepistemológicas engendradoras de Lélia Gonzalez ${ }^{4}$, Beatriz do Nascimento ${ }^{5}$, Luiza Bairros ${ }^{6}$, Makota Valdina Pinto ${ }^{7}$, Jaime Sodré, Mestre Didi, da Autoridade Afroancestrálica İyá Beatriz

4 Lembrança significativa de uma escuta conceitual de Lélia Gonzalez no Centro de Formação de Líderes, no bairro Mesquita, Nova Iguaçu, que na memória recordo das presenças de dois fotógrafos: Januário 5 Com a historiadora Beatriz Nascimento estivemos por algumas vezes juntos nas reuniões do Grupo de Trabalho André Rebouças, composto por estudantes da Universidade Federal Fluminense (UFF), na de Trabalho André Rebouças, composto por estudantes da Universidade Federal Fluminense (UFF), na
cidade de RJ, entre tantos outros momentos singulares.

6 Uma das consultoras preferenciais do projeto “Tradição dos Orixás”. Nas minhas consecutivas viagens TECAB com Mestre Didi, Juana Elbein dos Santos e Jaime Sodré, os encontros eram agendados com Luiza TECAB com Mestre Didi, Juana Elbein dos Santos e Jaime Sodré, os encontros eram agendados com Luiza Bairros, com a qual, por último como ministra da SEPPIR, estivemos muito juntos, relação que continu na sua dimensão ancestral, depois que voltou para casa como nos recobra Dirk Louw (2010, p.6). rância religiosa, enquanto presencialmente esteve entre nós afrodiaspóricos. 
Moreira Consta $^{8}$, professora Gésia de Oliveira ${ }^{9}$, İyá Vanda Ferreira ${ }^{10}$, Florinda de Souza Ferreira (Mãe Flor de Oya-Iyasan), Sueli Carneiro ${ }^{11}$, José Flávio Pessoa de Barros, Tania Maria Salles Moreira, Carlos Nobre, Bàbáláwo Ivanir dos Santos, entre tantos, outras e outros, tendo alguns voltado à massa de origem. Assim como outras e outros que prosseguem por aqui na Terra, entre nós, cuja extensa lista torna-se improvável mencionar a cabo.

Dinamizado e dinamizada existencialmente por uma anima bioafroancestrálica, empreendemos uma jornada de maneira a edificar intersubjetivações desnorteadoras, encontrando com e corroborando efetivamente processos de descolonização epistêmica, contra o apartheid epistêmico (BALDI, 2004), contra o racismo epistêmico (BRUNO, 2019), desconstruindo o epistemicídio, lutando contra o eurocentrismo (CARVALHO,1997) e incidindo para a descolonização do conhecimento (MIGLIEVICH-RIBEIRO; ROMERA, 2018) e das práticas.

Um dos principais desafios da perspectiva descolonial é o de pensar na dimensão civilizacional, não como retórica ou tergiversação. 0 determinante numa prática descolonial é a tarefa irrevogável de pensar fazer-sendo numa concretude afroaxiológica e/ou afrofilosófica, traduzindo-se numa comportamentalidade pretaexistencial, nas dispersões transatlânticas.

Neste sentido, indubitavelmente, não podemos nos referir à Série Pensamento NegroDescolonialsemnosdeteraumbrevehistóricodanossadinâmicaBioafroancestrálicaExistencial, que igualmente encontra afro-sintonia-ancestrálica com a "escrevivência" de Conceição Evaristo (2017). Afinal, a escrevivência tem visceral imbricamento com todo

8 Proeminente Autoridade Ancestral, fundadora do Território Ancestrálico de Matriz Africana Ile 0m Oju Aro, potencial engendradora do projeto "Tradição dos Orixás", na atualidade uma Ilustre Ancestral. 9 Uma proeminente colaboradora do projeto "Tradição dos Orixás", cuja relação se deu a partir do curso de língua e cultura yoruba, ofertado pelo IPELCY, em 1987, na atual cidade de Mesquita, na Baixada Fluminense, RJ. Uma fiel escudeira, afroepistemologicamente falando, por de pronto perscrutar a complexidade filosófica existencial da Cosmo-Afroexistencialização. Uma ilustre ancestral.

10 Outra mulher preta de cabedal importância, de notória capacidade organizacional, uma espécie de terapeuta do projeto "Tradição dos Orixás", junto com sua İyá (mãe uterocêntrica - Mãe Flor de Oya-Iyasan), e sua imã Vera Ferreira, outra fortaleza, ainda bem jovem, do projeto "Tradição dos Orixás , guardiã do racismo religioso ou da intolerância religiosa no Brasil a exemplo do livro "Marchar não é caminhar:

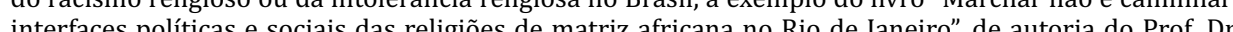
Bàb́lámo Ivanir dos Santos e do próprio "A Tradič̃o dos Orix́s", organizados por Edhine de Can. Dros Bàbáláwo I UNIRIO, e Lú́ Cló dio proprio 'A Tradição dos 0 11 Uma das docentes do curso de especializaça qu

que eu e Jorge Moraes organizamos na Faculdade Espírita do Paraná, no ano de 1998. Um lato sensu versando sobre um conteúdo teórico-metodológico intitulado "Culturas Africanas e Relações Interétnicas na Educac̃̃o Brasileira"; contando com oudros professores, a exemplo de José Flávio Pessoa de Barros, Nei Lopes, Wilson Roberto de Mattos, da UNEB, José Carlos Gomes dos Anjos, da UFRGS. esse processo contemporâneo hodierno, em que metodologias e epistemologias negras se dimensionam nas estruturas do Estado-Nação, de forma a incidir com prevalência, na direção oposta à Colonialidade do Saber (LANDER, 2005) que permeia as relações sociais das "Américas". Colonialidade cuja visão de mundo se inscreve nos ditames do "berço civilizatório matricial" (MOORE, 2012, p. 124) nomeado por Cheikh Anta Diop como "berço setentrional", que possui como substancialidade dos seus pressupostos a xenofobia, em detrimento do "berço meridional, que tem na xenofilia sua sustentabilidade como fundamento humano-existencial inarredável". Importante se faz essa demarcação para que não se tenha dúvidas da intencionalidade da coletânea proposta.

Diop, em conversa com Carlos Moore durante entrevista realizada em Dakar, Senegal, no ano de 1976, assevera que:

A história da humanidade permanecerá na escuridão até que seja vislumbrada a existência de dois grandes berços - o meridional, que inclui toda África e o setentrional, que corresponde ao espaço euro-asiático onde o clima forjou atitudes e mentalidades específicas (MOORE, 2012, p.119).

Como prognóstico prenunciado pelo complexo aparato afro-oracular, onde todo um descricionamento das prerrogativas do nosso "nexo ontogenético" Bioafroancestrálico-Existencial foi dimensionado, crescemos tomando conhecimento do devir constitutivo do nosso projeto-mítico-afrossocial, já estando pré-estabelecida toda uma jornada que foi se configurando, com os ritos de passagem civilizacional, de acordo com as fases etárias bioafroancestrálicas-existenciais e não estritamente religiosas, ou ainda, iniciática como se configurou na diáspora afro-brasileira.

Assim, eu, Olorode Ògìán Kálàfó Jayro Pereira de Jesus, nascido na Ilha de Itaparica, BA, cedo saí de Jiribatuba - distrito da referida ilha - migrando após a admissão ao ginásio, inicialmente para a cidade sede do município, Itaparica, em seguida para a capital soteropolitana, depois Itambé (região sul da Bahia), Riachão do Jacuípe e, finalmente, transferindo-me para Jequitibá, distrito de Mundo Novo, região Centro-Norte baiano. Toda essa peregrinação se justificava por conta de estudos que possibilitassem reflexão face aos questionamentos, por conta do que compreendo como destroços existenciais decorrentes da promiscuidade civilizatória a que fomos e estamos submetidos afrodiasporicamente. 
Quanto a mim, Míriam Cristiane Alves Obà Olórí-Ọba, nascida no sul do país, em Porto Alegre, RS, me ative com maior propriedade e encharcamento à minha questão-vida - que me acompanha desde o momento em que me percebi negra pelo olhar do outro (branco), aos sete anos de idade -, após minha conexão ancestrálica afrodiaspórica possibilitada pelo curso Pedagogia do Àșe, em 2005. Esse curso foi coordenado pelo meu professor, mestre e amigo Olorode Ògìyán Kálàfó Jayro Pereira de Jesus e pelo Bàbá Diba de Iyemonjá que, desde 2006, passou a ser meu Bàbálórìșà.

Nossas questões-vida se expressam na seguinte problematização: o que fomos e/ou éramos (África pré-colonial); o que fizeram de nós e/ou nos tornaram (colonialismo/imperialismo); o que poderemos voltar a ser ou vir a Ser (póscolonialismo/decolonial).

Essa problematização suleadora remete-nos a pensar sobre a afroancestralidade arrolada a uma afroepistemologia, partindo para uma ação junto e com o que nomeamos afrodiasporicamente de Territórios Ancestrálicos de Matriz Africana, despindo-nos da expressão "terreiro", como continua sendo ainda chamado na diáspora afro-brasileira. A expressão "terreiro" está imersa na arapuca e nas armadilhas do colonialismo e da vigente colonialidade, de modo que a sociedade a compreende a partir do maniqueísmo judaico-cristão, desde o lugar da religião, impondo-lhe a lógica ocidentalizante do dualismo bem versus mal, cuja visão está arraigada no imaginário social.

O ideário dessa afroepistemologia, constituidora do projeto "Tradição dos Orixás”, espraiou-se pelo Rio de Janeiro, nacionalizando-se por quase todo o Brasil, mediante atividades significativas com destaque para os estados do Sul, em particular o Rio Grande do Sul. Neste contexto de espraiamento, inauguramos em 2010, o DidáArá - Encontro Nacional de Tradições de Matriz Africana e Saúde, enquanto uma das ações da Rede Nacional de Religiões Afro-Brasileiras e Saúde, cujas reflexões envolvendo a afrobioética tornou-se mote suleador do encontro de 2012 e da última edição, em 2014. Discussão sobre afrobioética que retorna ao contexto nacional a partir o projeto RENAFRO Saúde e da interiorização da Política Nacional de Saúde Integral da População Negra (PNSIPN): programa de capacitação afrocentrada, de 2017, em parceria com o Departamento de Apoio à Gestão Participativa e ao Controle Social da Secretaria de Gestão Estratégica e Participativa do Ministério da Saúde (DAGEP/SGEP/MS), cuja presente publicação é fruto.
Ainda no âmbito do Rio Grande do Sul, nessa mesma perspectiva afroepistemológica, não poderíamos deixar de mencionar o projeto IléẸkớ- Formação Político-Pedagógica a partir da Filosofia e Teologia de Matriz Africana, de 2012, realizado em parceria com a Associação Remanescente de Quilombo Chácara das Rosas a partir de edital da Secretaria Especial de Políticas de Promoção da Igualdade Racial (SEPPIR). E o modo como incidimos sobre o processo de implementação da Política de Saúde da População Negra, por meio da Coordenação Estadual da Saúde da População Negra da Secretaria de Saúde do Estado do Rio Grande do Sul, onde estivemos na coordenação e assessoria (2011-2014), imprimindo a matriz civilizatória africana e toda sua bioafroancestralidade no pensar-fazer saúde coletiva.

A escrevivência acima desenvolvida se justifica, intentando explicitar conexão ancestrálica afrodiaspóricas, encontrando sintonia no que nos ensina a bioafroancestralizada Sueli Carneiro, recobrando que: "os passos vêm de longe”. Essa consigna explicita o que hoje encontramos no Núcleo de Estudos e Pesquisa E’LÉÉKÒ locus depositário de uma demanda afroepistêmica-ancestrálica, reprimida devido à colonialidade do saber, imperativa e determinante nas universidades públicas brasileiras, apesar das concessões como estratégia histórica e secular do EstadoNação. No E'LÉÉKÒ, nos colocamos a fomentar e potencializar redes intelectuais negras na perspectiva de enunciar "desde dentro" (SANTOS, 1976) metodologias e epistemologias nas quais o lugar preto, de matriz africana, afrodiaspórico importa.

No, com e pelo ÉLÉÉKÒ, estamos nos empenhando a criar possibilidades, deslocamentos e aberturas para "uma descolonização ao mesmo tempo ética e epistêmica" (SODRÉ, 2017, p. 15), para o que chamamos de uma Ciência Preta por meio da bioafroancestralidade e intersubjetivação nacional. E é nesse contexto que o segundo volume da Série Pensamento Negro Descolonial se insere.

Referências

BALDI, César Augusto. Para reinventar a imaginação jurídica. [Entrevista cedida a] Luciano Gallas Ricardo Machado. IHU Online, Revista do Instituto Humanitas Unisinos, São Leopoldo, n. 431, p. 1420, nov. 2013. Disponivel em: http://www.ihuonline.unisinos.br/artigo/5252-cesar-augusto-baldi.

BRUNO, Jessica Santana. Racismo epistêmico, tensionamentos e desafios à Universidade. In: Revista Nós Cultura, Estética e Linguagens, v.4, n.2, p. 34-61, 2019.

CARVALHO, José Carlos de Paula. Etnocentrismo: inconsciente, imaginário e preconceito no universo das organizaç̃es educativas. Interface, Botucatu, v. 1, n. 1, p. 181-186, ago. 1997. 
DEUS, Lucas Obalera de. Por uma perspectiva afrorreligiosa: estratégia de enfrentamento ao racismo religioso. Rio de Janeiro: Fundação Heinrich Böll, 2019.

EVARISTO, Conceição. Conceição Evaristo no Encontro Conexões Itaú Cultural 2017. [Entrevista concedida a] Thiago Rosenberg. Rio de Janeiro, RJ: Itaú Cultural, mar. 2017. Disponível em: https://www. itauculturalorg br/conceicao-evaristo-estara-no-encontro-conexoes-itau-cultural-2017. Acesso em: 10 fev. 2021.

GOMES, Edilaine Campos de; OLIVEIRA, Luís Cláudio de. A tradição dos orixás: valores civilizatórios afrocentrados. Rio de Janeiro: Mar de Idéias - Navegação Cultural; IPEAFRO - Instituto de Pesquisa Estudos Afro-brasileiros, 2019.

HENRIQUE, Joana Gorjão. Racismo em português: o lado esquecido do colonialismo. Rio de Janeiro: Tintada-China Brasil, 2016

JESUS, Jayro Pereira de. Terreiro e cidadania: um projeto de combate ao racismo cultural religioso afro e de implementação de ações sociais em comunidades-terreiros. In: ASHOKA EMPREENDEDORES SOCIAIS E TAKANO CIDADANIA (orgs.). Racismos contemporâneos. Rio de Janeiro: Takano, 2003. p. 185-212.

LANDER, Edgardo (org.). A colonialidade do saber: eurocentrismo e ciências sociais. Perspectivas latinoamericanas. Buenos Aires: CLACSO, 2005. Coleccion Sur Sur. Disponível em: http://bibliotecavirtual. clacso.org.ar.

LOUW, Dirk. Ser por meio dos outros: ubuntu como cuidado e partilha. [Entrevista cedida a] Moisés Sbardelotto. Tradução Luís Marcos Sander. IHU Online, Revista do Instituto Humanitas Unisinos, São Leopoldo, n. 353, p. 5-7, dez. 2010. Disponível em: http://www.ihuonline.unisinos.br/artigo/3687dirk-louw.

MIGLIEVICH-RIBEIRO, Adelia; ROMERA, Edison Orientaç̃es para uma descolonizaç̃o do conhecimento: um diálogo entre Darcy Ribeiro e Enrique Dussel. Sociologias, Porto Alegre, ano 20. n. 47, p.108-137, jan./abr., 2018.

MOORE, Carlos. Racismo e sociedade: novas bases para entender o racismo. 2. ed. Belo Horizonte: Nandyala, 2012.

SANTOS, Antônio Bispo dos. Colonização, quilombos: modos e significações. 2. ed. Brasília: Ayó, 2019.

SANTOS, Boaventura de Sousa. Para além do pensamento abissal: das linhas globais e uma ecologia dos saberes. In: SANTOS, Boaventura de Sousa; MENESES, Maria Paula (orgs.). Epistemologia do sul. São Paulo: Cortez, 2010. p. 32-83.

SANTOS, Juana Elbein dos. Os nagô e a morte: Pàdé, Àsèsè e o culto Égun na Bahia. Traduzido pela Universidade Federal da Bahia. Petrópolis: Vozes, 1976.

SODRÉ, Muniz. Pensar nagô. Petrópolis, RJ: Vozes, 2017.

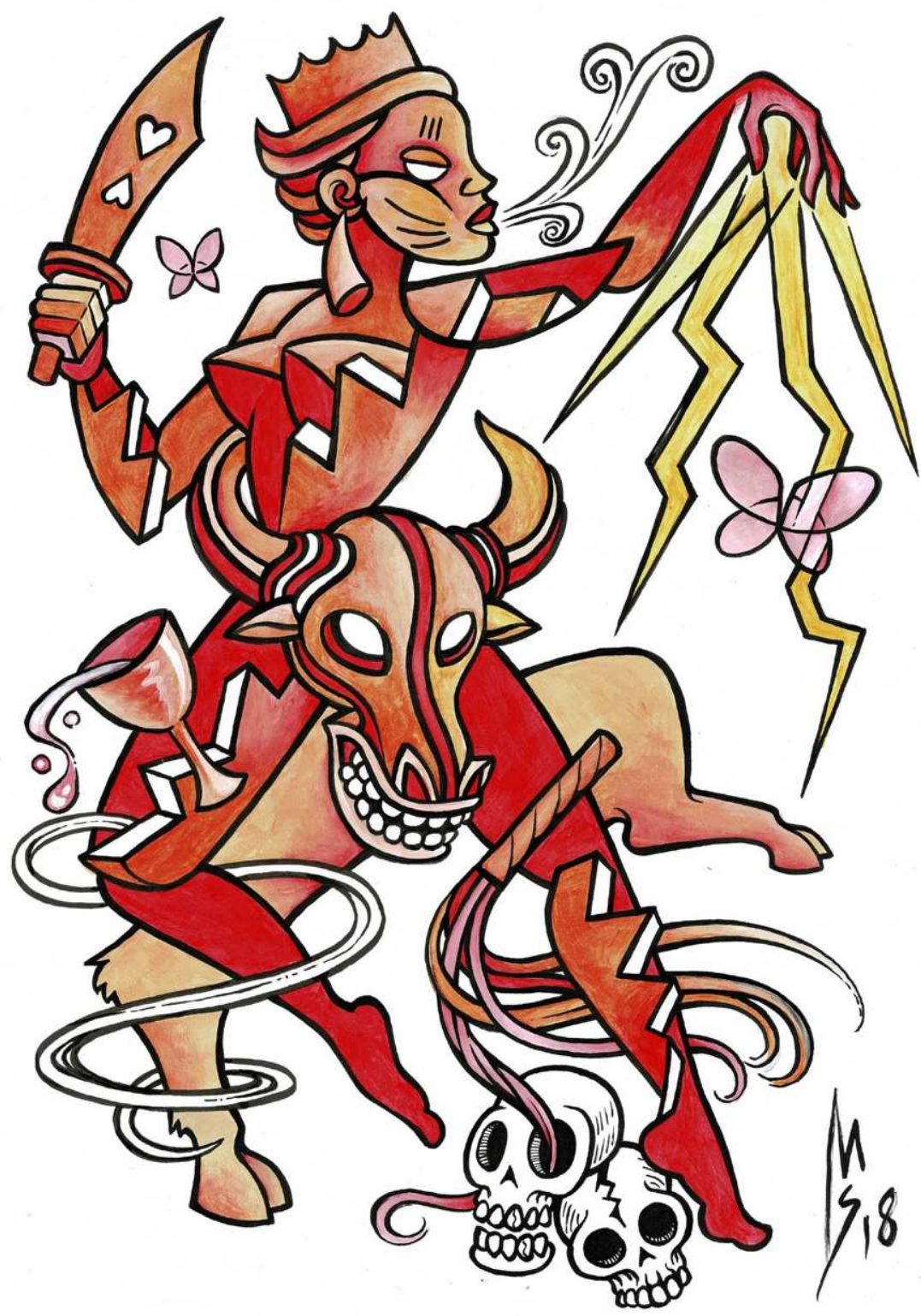


Yánsàn-Oya ${ }^{12}$

Oya, princípio feminino do fogo.

Única ebora-filha entre as Òrìsà femininas da esquerda.

Aquela que está ligada ao princípio físico e fenomenológico

do ar,

do vento,

da tempestade,

do relâmpago - ar mais movimento igual a fogo.

Oya é o aspecto feminino de Sàngó,

vermelho individualizado

vermelho-descendência no Àiyé e no ọ̀run.

Aquela que está associada à água,

à floresta e à terra,

$$
\text { aos animais, }
$$

aos espíritos - Egúngún.

Yánsàn-Ọa, aquela que possui como prerrogativa

a organização dos nove espaços do ộrun

- İyá-Mesan-Örun.

Princípio de vida no Àiyé

- só é possível a continuidade da vida, da existência,

através dos princípios de ancestralidade e descendência.

12 Oríkì (louvação) para OOya, construído a partir das obras: "Agadá: dinâmica da civilização africano-brasileira”, de Marco Aurélio Luz (2000); “Os Nàgô e a Morte: Pàde, Àsèsè e o culto Égun na Bahia”, de Juana Elbein dos Santos (2012); e "Dicionário yorubá-português", de José Beniste (2011).
Pretendemos aqui elaborar reflexões sobre a temática do amor. Partimos de problematizações sobre os livros "O Banquete", de Platão (2011), e "O Espírito da Intimidade - Ensinamentos Ancestrais Africanos sobre Maneiras de se Relacionar", de Sobonfu Somé (2007).

Platão, nascido na Grécia Antiga, expõe em seu texto as suas concepções sobre o amor por meio de diálogos entre os personagens. E Sobonfu Somé, por meio da tradição oral $^{13}$ transferida entre as gerações do povo Dagara, compartilha suas sabedorias acerca dos modos de relacionamento de sua comunidade. Portanto, as duas obras diferem-se em relação à compreensão e o sentido dado para as relações amorosas. Dessa forma, tais leituras nos auxiliam a complexificar os modos de ver e perceber o dispositivo ${ }^{14}$ do amor.

Dentre essas discursividades, vale salientar que são os princípios platônicos que carregam a legitimidade hegemônica em suas concepções sobre os modos de amar na modernidade/colonialidade ${ }^{15}$. Assim, nos termos dessa concepção, temos a produção de uma conduta que rejeita o mundo e os sentidos dos corpos para chegar a uma suposta verdade demarcada pela natureza do amor, alcançada pelo sujeito em sua ascese ${ }^{16}$ purificadora.

Esses pressupostos demonstram em seus sentidos uma crença na existência de uma epistemologia universal de mundo. A naturalização dessas 13 Na Tribo de Dagara, os ensinamentos e sabedoria dos mais velhos são transmitidos através da oraidade. "Uma das características fundamentais das culturas tradicionais africanas é a palavra, a tradição oral (Aguessy). Dito de outro modo, a palavra é um elemento fundamental para a compreensão do pensa14 É

14 É um conjunto de cadeias de variáveis que disputam entre si; são

15 A modernidade emerge de um determinado contexto sócio-histórico, em que a sua condição de possibilidade se tornou possivel enquanto discursividade por mérito da colonialidade (MALDONADO-TORRES, 2007). Ainda conforme esse autor, a partir da modernidade/colonialidade, emergem novas classifi16 Conjunto de práticas de domínio de si, considerados 16 do corpo em relação ao mundo. (PLATÃO, 2011) 
tramas institucionais captura e internaliza verdades cristalizadas acerca das existências, e sobre o fenômeno do amor ao longo dos séculos. Os efeitos destas noções ressoam em sociedades ocidentalizadas por meio de conjuntos de discursos que produzem realidades baseadas em enunciados racistas, machistas, patriarcais, cisheteronormativos, eurocêntrico e colonial, que instituem verdades, produzem opressões e delimitações de modos de vida. Por sua vez, concepções éticas, ontológicas e epistemológicas oriundas de produções discursivas não ocidentalizadas têm a potência de abrir fissuras sobre essas verdades instituídas, ao produzir outras condições de possibilidades de vivenciar o amor.

Com isso, o presente ensaio teórico tem como objetivos problematizar discursos instituídos pelo eurocentrismo ${ }^{17}$ sobre o dispositivo do amor e produzir um olhar crítico a esse modelo, ao expandirmos as reflexões a partir da ética do viver africano, na tentativa de reaprender sentidos descolonizados para o fenômeno amoroso.

Deste modo, o ensaio desdobra-se em três movimentos. 0 primeiro, intitulado "Amar a Falta", em que discutiremos a concepção de amor a partir de Platão (2011) ao salientar tal discursividade como base epistemológica na produção do pensamento colonial no Ocidente. No segundo, nomeado de "O Amor em Comunidade", trata-se de trazer para o texto discursos não ocidentais acerca dos modos de relacionamentos, ao compreender o amor enquanto uma experiência compartilhada e vivenciada coletivamente, ao nos direcionarmos para a ética do viver africano. No terceiro movimento "Descolonizar o Amor", busca-se, através das discursividades apresentadas, questionar os pressupostos epistemológicos que fundam os conhecimentos instituídos, ao problematizá-los a partir do pensamento descolonial, na tentativa de descolonizar os modos de compreender e experienciar as relações amorosas. Enfatiza-se, também, a importância de inventar modos possíveis de entendimento e de experiências sobre o dispositivo do amor no contemporâneo, ao afirmar as pluralidades de concepções de mundo, ou de cosmopercepções ${ }^{18}$ fora do Ocidente para esse fenômeno na existência humana.

17 Para Mignolo (2008), eurocentrismo é o nome dado à hegemonia de uma forma de pensar fundamentad no mundo grego, latino e nas seis línguas europeias e imperiais da modernidade; isto é, da modernidade/ no mundo grego, latino e nas seis linguas europelas e impeliais da modernidade, isto é, da modernidade/
colonida

coloca em discuss̃̃ùmí (2017, p.39) ao debruçar-se sobre as discussões de gênero na sociedade Yorubá nando, portanto, o conceito de "cosmovisão" do Ocidonte que privile conimaña a da visão, e apresenta o conceito cosmopercepc̃̃o ou cosmosensaç̃o marcando as culturas que privilegiam outros sentidos ou o conceito cosmopercepção ou cosmosensação, marcando as culturas que privilegiam outros sentidos ou com maior abertura para descrever a concepc̃̃o de mundo por parte de diferentes grupos culturais.
Amar a falta

O filósofo grego Platão (2011), em seu livro “O Banquete”, propõe-se a percorrer a temática do amor. A partir do diálogo dos personagens postos nessa obra, acontecem as exposições das concepções sobre o tema. Cada um dos participantes, homens brancos e gregos, manifestam aquilo que pensam sobre o amor, suas particularidades e suas implicações na vida dos sujeitos. Isso acontece, no contexto da obra, para apresentar as principais concepções filosóficas de Platão. Cada um deles salienta os diversos sentidos do amor e como ele se faz presente tanto nas práticas afetivas entre os amantes, como também na prática da filosofia, no exercício de uma profissão, entre outras.

Sócrates, personagem de Platão (2011), afirma que o amor está intimamente relacionado ao desejo, pois para ele o amor consiste na inclinação resultante de um desejo. Sendo assim, o amor exige que, quando se ama algo, exista o desejo por determinado imaginário suposto no objeto amoroso. Portanto, o amor sempre se direciona a algum objeto. Entretanto, como enfatiza esse personagem, o objeto do amor só pode ser desejado quando existe uma falta e não quando se possui.

0 amor, nesse sentido, seria a falta, pois, segundo Sócrates, ninguém deseja aquilo de que não precisa ou que já tenha. Sócrates declara que o que se ama é unicamente aquilo que não se tem. 0 objeto do amor está ausente, mas é solicitado. Ainda, Sócrates menciona a verdade como um exemplo. Para ele, o desejo pela verdade, que é o objeto da filosofia, aponta que ela se mostra como uma falta e que, portanto, deve sempre ser buscada. Mas, por sua natureza engenhosa, a verdade é algo que está sempre mais distante, porque quando se acredita tê-la alcançado, ela nos escorre entre os dedos (PLATÃO, 2011)

O amor em Platão, então, está relacionado a uma tendência natural que visa atingir uma perfeição ética pela busca e encontro do Bem ${ }^{19}$. Seria esse amor que encaminha os sujeitos a modos de vida e de consciência mais evoluídos ${ }^{20}$. Desse 19 Em Platão as noções de Bem e Mal estão diretamente ligadas à moral e tem metafisicamente um sentido fundam formas abolutas e universais desde Sócrates o Platão [ ] Nesse caso tais noç̃̃es têm um sentido metafísico. formas absolutas e universais desde Sócrates e Platão [..... Nesse caso, tais noçôes têm úm sentido metafisico. filósofo com a pretensão de instituir um sentido considerado mais elevado da existência humana; um certo tipo de "tendência" natural. 20 Aqui a ideia de evoluídos, em Platão (2011), é entendida enquanto homens que alcançam deter (c) 
modo, toda ação humana tem como objetivo final alcançar o Bem. 0 amor, em sua compreensão mais elevada, consiste na inclinação em chegar a esse Bem. Este é um dos sentidos do amor para Platão, e que se institui nas tramas relacionais a partir de noções de ideal de amor produzido na Modernidade/Colonialidade.

Entretanto, podemos perguntar: como esse amor ideal produz sentidos no contemporâneo povoado por multiplicidades de expressões?

0 amor em Platão só pode ser compreendido se levadas em consideração suas concepções filosóficas e o terreno histórico no qual elas emergiram, se desenvolveram e se tornaram possíveis. Para nos aproximarmos da compreensão dessa noção que se institui como modelo para experiência amorosa, vamos partir de uma abertura proposta por Foucault (2012), em sua obra História da Sexualidade: o uso dos prazeres.

Nesse livro, Foucault (2012) realiza uma análise das questões relacionadas ao modo como os sujeitos se constituem enquanto sujeitos de desejo e de prazer na Grécia Antiga. 0 autor parte do termo sexualidade para analisar o contexto teórico e prático ao qual ela é associada. Desta forma, verifica que o uso da palavra foi estabelecido em relação a outros fenômenos que possibilitaram e desenvolveram campos de conhecimentos diversos.

A instauração de um conjunto de regras, normas, instituiç̃̃es e as mudanças no modo pelo qual os sujeitos são levados a dar um determinado sentido e valor a sua conduta, prazeres, sentimentos e sensações constituem modos de subjetivação, e é essa dinâmica da relação consigo e com o outro que acaba sendo objeto de reflexão para os gregos.

Dizendo de outro modo, não seria propriamente o ato, e sim o conjunto dessa dinâmica do desejo que seria levado à ação, e essa ação, por sua vez, estaria ligada ao prazer, com a qual finalmente seria possível considerar que o prazer ocasionaria o desejo. Assim, trata-se de analisar a formação e o desenvolvimento das práticas pelas quais tais homens foram levados a prestarem atenção em si e a se reconhecerem enquanto sujeitos de desejo, constituindo uma experiência da sexualidade.

Na Grécia Antiga, a atividade sexual era entendida como parte da natureza humana, ou seja, não poderia ser considerada má (FUGANTI, 2008). Os prazeres, nessa perspectiva, são problematizados moralmente, justamente por serem considerados naturalmente ${ }^{21}$ necessários, pois é por meio deles que os seres vivos podem se são aqueles que acessam um pensamento posto como "verdadeiro" nesses termos.

21 A palavra Natural, no contexto platônico, representa a condição do corpo humano em buscar o pra- reproduzir e perpetuar a espécie. Todavia, por ser tomado como inteiramente dependente do corpo e comum a todos os animais, o prazer é considerado inferior ${ }^{22}$ A impetuosidade, que também lhe é própria, leva a atitude sexual a transbordar na sua atuação com o desejo. Sendo assim, isso pede uma delimitação: em que medida e até que ponto é cabível praticar a atividade sexual?

A solução dada por Platão (2011) seria de que é preciso discriminar moralmente tal atividade, impondo freios: o temor, a lei e o discurso verdadeiro. Ou seja, se no pensamento grego clássico o prazer constituía demasiada força natural, para Platão seria necessário o enfrentamento de tais forças através da moral, a fim de dominá-las e garantir sua adequada economia, para que assim fosse possível viver honrosamente (FUGANTI, 2008). Esse enunciado nos posiciona diante de uma problemática ética: a preocupação grega de como se conduzir. Para Platão, essa ética e o amor constituem uma relação intrínseca.

Nessa perspectiva, a relação entre rapazes ${ }^{23}$ era vista na Grécia Antiga como algo arrebatador e comum entre os corpos. Também, por isso, os gregos procuravam exercer essas práticas de forma a constituir condutas dignas, para não desonrar suas famílias e a polis, entre outros. Percebe-se aí a produção de uma subjetividade que passa a questionar o uso dos prazeres e como se conduzir nessa relação com o ser amado.

Havia também uma preocupação com a honra, devido aos vexames oriundos da atração dos mais velhos pelos rapazes e vice-versa; e, portanto, uma forma de modificar esse modo de relacionar-se com o outro a partir de um cuidado de si (FOUCAULT, 2012). Emergem cuidados de si, e noções que, nesse contexto, se baseiam em critérios que negam o corpo a partir da abstenção como um tipo de demonstração de domínio próprio. Acontece, portanto, uma inversão da situação: zer na reprodução da espécie. Dessa forma, por ser natural, torna-se comum aos corpos, e, portanto deve-se controlar e dominar tal "ímpeto natural", pois o filósofo acreditava que em demasia, tal praze levara ao dispêndio excessivo de energia. 0 intuito era a economia dessa energia, para direcioná-la em um investimento em si.

位 mans, o que difo, pela

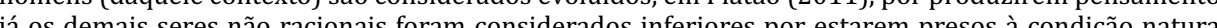
do corpo. dicotomias e dualismos, ao diferenciar a populac̃o do mundo entre inferiores e superiores, irracionas e racionais, primitivos e civilizados (QUUANO, 1991). Dessa forma, essa lógica classifica e objetifica os (

23 Nessa dinâmica que direciona e constitui o sujeito dito ideal para o amor, eram considerados sujeitos de direitos apenas os homens brancos, que representavam a maior parte constituinte da cidade gestão da polis não considerava, ou ainda, desumanizava outras formas de estar em comunidade. 
de uma dominação estabelecida pelos rapazes através da provocação aos corpos decadentes que os levam ao excesso e ao arrebatamento, para um domínio de si, a partir da abstenção dos prazeres do corpo, da negação e do redirecionamento do desejo (FUGANTI, 2008). Assim sendo, os homens devem estar preparados para serem os senhores de seus prazeres. Aqueles que sabem o que querem e como se portar de maneira dita honrosa na relação com o outro, demonstrando o prazer que exercem sobre si, de acordo com a moral do cuidado de si platônico.

O discurso idealista, a partir das reflexões sobre a conduta, surge com o intuito de alcançar algo que era entendido como um pressuposto existente para o filósofo: a verdade; e que para chegar nela é preciso conquistar uma conduta purificada. E é essa relação com a verdade que irá estruturar o discurso do filósofo.

Não é na conduta, mas na natureza ou verdade do desejo que está o real problema e a verdadeira prova de sabedoria e liberdade. Ou seja, o que nos diz o discurso platônico é que a condição de acesso à verdade será demarcada pela natureza do amor que o sujeito conquista em sua ascese purificadora e nas práticas de domínio de si que o constituem como sujeito moral. Assim, a relação entre o mundo dos corpos e o mundo dos ideais será possível por meio do verdadeiro amor, o amor pela verdade. Da mesma forma, o verdadeiro amor é um grande desejo de imortalidade, de eternidade e do além.

Podemos pensar uma crítica, com Luis Fuganti (2008), na qual essas normativas criam um novo desejo naquele contexto: o "amor verdadeiro" que pertence ao "homem purificado" e liberto dos prazeres corporais; o desejo de ser um homem virtuoso, aquele que purifica sua alma e liga seu desejo às ideias permanentes. Antes do discurso platônico, a preocupação dos gregos consistia em como conduzir-se diante das paixões arrebatadoras. Com o surgimento dessa narrativa, a reflexão fora direcionada para uma busca do ser do amor, definindo o verdadeiro amor e o verdadeiro amante. É o discurso purificado, de acordo com Luis Fuganti (2008), que irá impulsionar esse pensamento acerca do amor, bem como inaugurar o sujeito do conhecimento, e com o pensamento rigoroso teríamos acesso à dita verdade universal. Dizendo de outro modo, a verdade não pertence mais a um tempo particular como na Grécia Antiga, mas está fora, transcende a dimensão temporal para entrar no domínio do imperecível.

Por conseguinte, em nome de um enigmático bem, na Grécia Antiga é fundada a crença nas essências inteligíveis com valores supremos que existem separados do corpo sensível, e também é criada uma hierarquia de sentidos, apreendidos ao mesmo tempo como causas da ordem universal e paradigmas das condutas humanas, restituindo assim a ordem ideal. Dessa forma, esse valor emerge pela invenção de uma ficção e pela condensação dessa crença em um mundo ideal e perfeito.

Por sua vez, esses enunciados atuam como vínculos que terão de permanecer durante a vida. Ou seja, discursos instituídos como verdadeiros conduziram e conduzem nossas experiências, inclusive as amorosas. É interessante saber como se constituem as experiências de si e dos outros a partir desse vínculo e dessa obrigação. Para Foucault (2016), as verdades são como um tipo de inscrições que se encontra na raiz de certos tipos de discursos, e elas fazem com que passem por legítimos, atuem como obrigações e produzem formas de viver. Com isso, podemos nos questionar como nos constituímos em relação a essas verdades e como experienciamos o amor a partir desses vínculos.

Esses mesmos valores idealizados, absolutos e verdadeiros ainda podem ser observados enquanto bases constitutivas dos valores da lógica na qual vivemos atualmente, pois estão a compor a modernidade/colonialidade. Por exemplo, no paradigma positivista, que seria como certo tipo de refinamento da instituição da verdade como instância suprema, tem como expressão máxima e legitimada a razão cartesiana. Essa ótica de mundo emerge inspirada na filosofia platônica, e apesar de constituir-se em meio às rupturas e contingências está interligada ao surgimento da epistemologia do pensamento colonial.

\section{0 amor em comunidade}

Na obra de Sobonfu Somé (2007), a autora nos insere em uma discussão não sistematizada, na forma de fragmentos, sobre os modos de relações, ao produzir paisagens a partir de sua compreensão de intimidade enquanto sentido primordial do relacionar-se em sua comunidade. Sobonfu Somé compartilha suas vivências na comunidade africana Dagara, em "O espírito da Intimidade, Ensinamentos Ancestrais Africanos sobre Maneiras de se Relacionar", apresentando outro modo de experienciar o amor.

Sobre a comunidade em Dagara, Sobonfu Somé afirma que não possui as amenidades que o povo do Ocidente tem. É uma vida "inspirada pela terra" (SOMÉ 
2007, p.10), na qual eles plantam o que consomem; tendo como experiência outra relação com a produção e o consumo; e cuja principal fonte de negociação é a troca. Na vida em comunidade, a pessoa vive em outro ritmo menos acelerado em relação ao tempo do ocidente; de modo a vivenciar o momento e a comungar com a terra e a natureza. Nesse sentido, de acordo com Jean Kashindi (2017) uma vez que qualquer vida humana depende de outras vidas não humanas (ar, água, fogo, terra, entre outros), resulta que os seres humanos receberam e continuam a receber a vida de outros seres não humanos. Para Jean Kashindi (2017, p. 34) "a ética tradicional africana reconhece o vínculo existencial entre as pessoas e o meio ambiente, a dívida que cada geração tem com seus antepassados e sua consequente responsabilidade para com o seu legado".

A intimidade, em termos gerais, apresentada por Sobonfu Somé (2007) é uma canção do espírito, que convida duas pessoas a compartilharem seus espíritos. Conforme os ensinamentos africanos, existe uma dimensão espiritual, independentemente de sua origem. Duas pessoas unem-se porque o espírito as quer juntas. Assim, é "importante ver o relacionamento como algo movido pelo espírito e não pelo indivíduo" (SOMÉ, 2007, p. 19). Da mesma forma, a noção de espírito auxilia a manter a conexão consigo e com o coletivo.

Os ancestrais também são chamados de espíritos; e eles têm a capacidade de ver não apenas o mundo invisível do espírito, mas também este mundo: "Eles veem dentro e fora de nós. Sua visão cria dimensões” (SOMÉ, 2007, p. 20). Em um relacionamento existe uma "tendência natural" de os espíritos se unirem (SOMÉ, 2007, p. 23). Quando dois espíritos conseguem de fato comungar profundamente, as pessoas estabelecem entre elas uma forte conexão, sincera e amorosa.

Sobonfu Somé (2007), ao mencionar os integrantes da sua comunidade que vão à cidade, conta que em estes, em sua maioria, param de desenvolver a conexão com o espírito e o deixam de lado. Quando vão para a cidade se desconectam do espírito e o procuram somente quando precisam resolver algum problema. A autora, ao pensar as relações do Ocidente, acredita que os relacionamentos são movidos pelo ego, pelo individualismo e pelo controle; e que, portanto, se faz necessário reconhecer que os relacionamentos são baseados no espírito.

Na comunidade existe uma forte crença em um espírito poderoso presente, que deve ser honrado, ao invés de desprezado, para que se tenha prosperidade nos relacionamentos. Esse ensinamento é transmitido para a criança, para que assim ela possa se conectar e reconhecer a existência desse espírito (SOMÉ, 2007). O comprometimento com as ancestralidades, de acordo com Jean Kashindi (2017), significa que cada geração deve reconhecer uma dívida para com os seus antepassados, e por isso, deve responder à mesma através da responsabilidade pelo seu legado. Dessa forma, se dá continuidade à busca de fortalecer e solidificar a força da vida, considerada como a pedra angular da ética africana. Assim sendo, cada geração deve reconhecer e comprometer-se com a dívida ancestral.

A comunidade é o lugar onde as pessoas compartilham seus dons e recebem as dádivas dos outros. Quando não se tem uma comunidade, não se é escutado, não se compartilha experiências coletivas e espirituais. A carência desse tipo de relação enfraquece a "psique", e possivelmente torna a pessoa vulnerável ao consumismo e a todas as coisas que o acompanham (SOMÉ, 2007). Quando não se elabora esses dons, vivencia-se um bloqueio interior que nos afeta espiritual, mental e fisicamente. Um dos princípios de Dagara sobre relacionamentos é que esse não é um assunto privado, ou seja, "nosso" relacionamento não é sobre dois (SOMÉ, 2007, p.28).

Assim, junto a Jean Kashindi (2017, p.11), vislumbra-se a relacionalidade da vida para a comunidade: "qualquer pessoa, depende de outras pessoas; a partir disso, pode-se afirmar que ninguém é totalmente independente e ninguém é definitivamente inútil", pois para o autor, na ética Ubuntu ${ }^{24}$ toda a vida é relacional. Nesse aspecto, torna-se importante ressaltar que as perspectivas culturais sobre os modos de relacionalidades são denominadas de cosmovisões; em grande parte esse termo emerge de certas leituras eurocêntricas. No entanto, com Oyèrónké Oyewùmí (2017) tensionamos o termo "cosmovisão", pois tal denominação demonstra o sentido da visão como primordial na produção da realidade. Ou seja, o mundo nessa perspectiva é percebido exclusivamente pelo olhar, pelo ato de ver. Esse termo, portanto, exclui outros modos de descrições culturais que consideram, na construção de significados, a relação intrínseca da combinação de sentidos. Assim sendo, o termo cosmopercepção (OYEWÙMI, 2017) diz mais sobre o conjunto dos sentidos imbricados no ato da percepção e compreensão da realidade do que o privilégio de um sobre os outros.

24 "Quando dizemos que "ubuntu" é a humanidade como um valor, a principal alusão que se faz é ao valor da vida. Uma vez que todos os demais valores que expressam ubuntu - a generosidade, a solidariedade, a responsabilidade a partilha, a empatia, a compaixão - ficam sem nenhum fundamento se não servirem para gerar mais vida; vivenciar ubutiu a compa enaía - ficam sem nenhum fundamento se não sertanto a própria vida quanto a dos outros" (KASHINDI, 2017, p. 21). 
Sobonfu Somé (2007) reflete sobre os modos de se relacionar e nos diz que na cultura moderna, em contraste com Dagara, os relacionamentos não acontecem dessa forma, pois não se tem uma noção de comunidade; no Ocidente as pessoas costumam apreender que um relacionamento é "nosso", quando na verdade é da comunidade. A ausência de uma verdadeira comunidade deixa o casal responsável por si e pelas coisas à sua volta. Assim, as possibilidades de atender suas necessidades ficam reduzidas. 0 relacionamento se torna a comunidade da pessoa; e quando o outro não preenche esse papel de produzir uma comunidade, o sujeito se sente insuficiente, ou ainda, fracassado. E segundo a autora, isso afeta a "psique" das pessoas, pois, faz com que se sintam sem lugar de pertencimento (SOMÉ, 2007, p.28).

Dessemodo, morarsozinhotambéméummodoqueempobreceaspossibilidades de vida. Porém, para Sobonfu Somé (2007), quando se tem um grupo em que há preocupação mútua, este ajuda a trabalhar o propósito de vida; no entanto, somente a dois, isso se torna mais difícil, pois passa a exigir demais do outro. Segundo Sobonfu Somé (2007), trazer o espírito de outras pessoas para nossas vidas é importante, pois ajuda a perceber e compreender suas próprias limitações; e que por sua vez, a realidade se expande, pois, inversamente, quando se mantém tudo no privado, o relacionamento acaba sobrecarregado. Assim sendo, "precisamos estar abertos às outras pessoas para que os relacionamentos funcionem" (SOMÉ, 2007, p. 35). Para Jean Kashindi (2017), estar com o Outro é perceber a interdependência que nos constitui como seres humanos, é estar consciente da força vital que possibilita a nossa permanência na vida. Assim, esse "Outro", para a ética africana, não se reduz aos seres humanos, mas inclui também outros seres animados e inanimados (KASHINDI, 2007, p. 22).

Do mesmo modo, ao pensar a produção da intimidade no Ocidente, Sobonfu Somé (2007) reforça a importância de constituir uma comunidade. Para ela, aqueles que moram no Ocidente podem criar uma noção de comunidade em sua cidade. Podem fazer isso constantemente, apoiando uns aos outros, pois cada um de nós precisa de uma rede para se apoiar. Ao pensar em grupos que seguem um objetivo comum no Ocidente, Sobonfu Somé (2007) diz que são tentativas de recriar uma comunidade maior, já que as que existiam foram destruídas. A única diferença é que a maioria dessas comunidades não se concentra no espírito. Tendem a deixar o espírito fora de sua comunidade, o que se apresenta enquanto um erro, pois o espírito existe como um guia de toda comunidade.
Outro exemplo que Sobonfu Somé (2007) apresenta é que se uma criança cresce achando que sua mãe e seu pai são sua única comunidade, quando ocorre algum problema e os pais não conseguem resolvê-los, não se tem a quem recorrer. Nesse sentido, os pais são os únicos responsáveis por aquilo que a criança se torna. Existe, dessa forma, uma grande responsabilização dos pais, que se encontram presos à instituição família, representada pelo homem e pela mulher. Dar à criança um sentido maior de comunidade auxilia a não depender apenas de um adulto. Assim, a criança também pode procurar alguém de sua escolha. Como seres humanos, temos limitações; por isso a crença na potência da comunidade, pois para educar precisamos do apoio dos outros (SOMÉ, 2007, p. 38). Essa determinada interação entre seres humanos e outros seres ou entidades cósmicas produz sentido para a comunidade, primordialmente para "gerar, cuidar e transmitir a vida" (KASHINDI, 2017, p.21). Dessa forma, a vida é considerada, na cosmopercepção africana, como o valor maior, o bem supremo que deve ser transmitido desde pequeno (OYEWÙMI, 2017).

Ao questionar-se como podemos progredir para uma estrutura familiar de relacionamentos "saudáveis", Sobonfu Somé (2007, p.38) diz que "o fator principal, é a comunidade construir comunidades que se possam confiar uns nos outros", e continua, ao dizer que podemos começar a expandir nossa comunidade ao sair de casa, conversar com os vizinhos e nos ajudar mutuamente. Nutrir pequenos relacionamentos para que, um dia, a comunidade possa se beneficiar. Para criar uma comunidade que funcione, "é preciso observar cuidadosamente alguns de seus fundamentos: espírito, criança, anciãos, responsabilidade, generosidade, confiança, ancestrais e rituais" (SOMÉ, 2007, p.40). Para a autora, esses elementos formam uma base sólida para uma comunidade.

O sentido do ritual em Dagara é uma cerimônia em que é chamado o espírito para servir de guia, para supervisionar nossas atividades. "Os elementos do ritual nos permitem estabelecer conexão com o próprio ser, com a comunidade e com as forças em nossa própria volta" (SOMÉ, 2007, p. 47). Assim sendo, através de rituais é possível criar vínculos compartilhados de intimidade e fortalecer a coletividade.

0 ritual é, portanto, como um jantar no qual cada um traz um ingrediente. Algumas pessoas trazem cebolas, outros tomates, algumas trazem alface, pimenta e assim por diante. "Depois se reunir todos os elementos, você verifica quais funcionam melhor, todo conceito de intimidade é fundamentalmente derivado do ritual" (SOMÉ, 
2007, p. 52). Para os ensinamentos de Dagara, uma forma de começar a caminhar na direção de uma vida íntima saudável é reconhecer o divino em tudo.

Quando entendemos que a terra na qual caminhamos não é apenas sujeira que as árvores e os animais não são apenas fontes para nosso consumo, então podemos começar a nos aceitar como espíritos, vibrando em uníssono com todos os outros espíritos à nossa volta. Nossa conexão com todos esses espíritos viventes ajuda a determinar o tipo de vida íntima que teremos (SOMÉ, 2007, p. 89).

Em Dagara, para além do bem-estar de seu próprio relacionamento, a intimidade saudável tem o poder de aumentar a energia curadora de tudo à sua volta. "Damos porque queremos dar e não nos isolamos ou nos retiramos da sociedade. Somos estimulados a expandir e compartilhar nossas dádivas, como casal, com a comunidade" (SOMÉ, 2007, p. 102).

$\mathrm{Na}$ comunidade, os conflitos nascem de desafios apresentados pelo espírito. São dádivas que ajudam a avançar. "É por meio do conflito que ganhamos conhecimento de nós mesmos e descobrimos novas situações para pôr em prática nossos dons" (SOMÉ, 2007, p.113). A autora diz que para a comunidade, o conflito não deve ser nutrido, mas escutado, de modo que devemos tomar medidas apropriadas para lidar com o espírito por trás do conflito, pois ele é como um aviso que a energia espiritual está estagnada e que, portanto, precisa de movimento.

Assim sendo, o sentido de vida para a ética africana é primordial para a continuidade da existência; da mesma forma, a transmissão de tal compreensão é um compromisso ético com o fortalecimento dessa vida. 0 relacionamento amoroso, assim como qualquer outro vínculo, é vivenciado em coletividade e está intimamente atrelado ao fortalecimento da existência. 0 existir estabelecido em rede se torna mais forte e promissor a partir dessa perspectiva. Esses pressupostos demonstram que a coletividade é o maior valor da comunidade, em contraponto ao individualismo, sentimento de falta e idealizações pertinentes a crenças em um homem onipotente/onipresente diante do mundo. Na cosmopercepção em Dagara, o relacionar-se é inerente à trama existencial, composta pela multiplicidade de expressões de vida (OYEWÙMI, 2017).
Descolonizar o amor

O giro epistêmico descolonial é uma consequência da formação e constituição da matriz colonial do poder, que tem como base o eurocentrismo atuando diretamente na constituição da modernidade; e que historicamente promove uma apropriação da legitimidade colonial do poder (QUIJANO, 2010).

Para mobilizar o descolonizar das percepções de mundo, é fundamental se desprender da ótica colonial e promover outros sentidos sobre as concepções de racionalidade e de ciências. Assim, o pensamento descolonial inaugura uma alternativa contra a hegemonia do eurocentrismo ao abrir condições de possibilidades para um pensamento que pressupõe a diferença e a pluriversidade do conhecimento (MIGNOLO; CASTRO GÓMEZ, 2007).

Walter Mignolo e Santiago Castro Gómez (2007) salientam que o pensamento descolonial tem como objetivo a descolonialidade do poder; ou seja, o tensionamento dos discursos hegemônicos a fim de possibilitar movimentos de desprendimentos e aberturas no processo de descolonizar o saber e o ser, pois a genealogia do pensamento descolonial pressupõe a pluriversalidade e a multiplicidade de existências e racionalidades. A colonialidade do ser, conceito desenvolvido por Nelson Maldonado-Torres (2007), diz respeito à experiência vivida do colonialismo e os efeitos da mesma na linguagem de uma sociedade; esse fenômeno social representa a identidade de um determinado corpo social. 0 conceito de colonialidade do ser emerge como um desdobramento da colonialidade do poder, e torna-se fundamental para pensar os efeitos da colonialidade na experiência existencial, subjetiva e histórica dos sujeitos.

0 pensamento descolonial se opõe à lógica moderna que é fundada através de racismos, epistemicídios e genocídios de populações, e que, na formulação das bases onto-epistemológicas de conhecimento colonial, colocam as diferenças culturais como inferiores, desprovidas de racionalidade e, portanto, passíveis de opressões, silenciamentos, invisibilidades e extermínios.

Desse modo, salientamos que a colonialidade também se expressa nos modos de se relacionar e se experienciar as relações amorosas, ao perpetuar as concepções de um ideal amor, baseado em uma verdade universal. 0 discurso platônico sobre um ideal do amor apresenta um descaso com o mundo sensível, dos 
afetos, da espiritualidade ${ }^{25}$, da pluriversidade dos modos de relação e da diversidade dos encontros; da mesma forma, a universalização de uma verdade que ocasiona e continua a produzir epistemicídios ${ }^{26}$ de outros saberes em prol de um sujeito ideal, possuidor de uma razão universal. Ou seja, tais discursos coloniais constituem mecanismos institucionais que, por sua vez invisibilizam, marginalizam e oprimem as demais formas coexistentes que se diferem do modelo normativo e hegemônico do Ocidente, com o objetivo de realizar a manutenção dessa lógica na construção da realidade social.

Estas crenças influenciam diretamente o modo como nos relacionamos amorosamente, pois essa noção de mundo se pretende enquanto modelo unívoco de experienciar as relações amorosas, gerando sofrimento àqueles corpos que não vivenciam o amor da mesma forma. A lógica Ocidental, posta e naturalizada como uma formação histórica legítima de perceber e estar no mundo, realiza a manutenção de estratificaçõe ${ }^{27}$ afetivas no presente. Entretanto, essa lógica idealista de conceber a existência passa a cristalizar o devir dos corpos no mundo. Torna-se fundamental o movimento de tensionar os discursos regularizadores dos modos de vida e de produção de conhecimento.

Em contraponto à experiência calcada pelo eurocentrismo sobre o dispositivo do amor, os saberes ancestrais, conforme Sobunfu Somé (2007), nos apresentam paisagens de relações amorosas não baseadas na falta, ou ainda, em um ideal. Sua leitura nos sinaliza um modo de relacionar-se que não possui critérios baseados em individualismo e/ou imagens idealizadas de mundo. Inversamente, tais saberes trazem como ponto de condução um modo de relacionamento ético, com o espírito da comunidade e da intimidade produzida em meio às relações constituintes das mesmas, e desse modo, diferindo-se também de relações baseadas apenas em combinatórias dicotômicas entre homem e mulher.

25 Na matriz civilizatória africana, a espiritualidade é uma dimensão mítica fundamental da existência. "O pensamento mítico não implica ausência de racionalidade, mas uma utilização da razão de modo dife"O pensamento mitico não implica ausência de racionalidade, mas uma utilização da razão de modo
rente daquela proposta pelo pensamento científico" (ALVES, SEMINOTTI, DE JESUS, 2015, p.107).

260 fascismo epistemológico existe sob a forma de epistemicídio, cuja versão mais violenta foi a conversão forçada e a supressão dos conhecimentos não ocidentais levados a cabo pelo colonialismo europeu (ALVES, SEMINOTTI, DE JESUS, 2015, p.106).

27 Deleuze (1925-1995) elabora um diama da subjetividade sobre o pensamento foucaultiano, constituído de três planos e uma invaginaçãa: Plano do Saber ou também chamado de Estratos: Plano do Poder ou das forças e o Plano do Fora, contendo também uma invaginação relativa à dobra da subjetividade. Os estratos ou saberes que compõem esse diagrama estão relacionados e dizem respeito a jetividade. Os estrats ou saberes que conpóm esse diagrana estão relacionados e dizem respeito ao por visibilidades (as coisas)
A partir da matriz civilizatória africana, Sobonfu Somé (2007) nos apresenta o modo de relação de sua comunidade, produzida como uma rede de apoio que se fortalece no coletivo e nas bases dos relacionamentos daquele determinado espaço e tempo. Outras condições de perceber o amor; conexões com os espíritos e sintonia com os ancestrais. Nesse sentido, somos convidadas e convidados a ampliar o campo do pensável com diferentes modos de vida que resistem à colonialidade dos corpos

Santos (2010, p.544), quando aborda a "ecologia dos saberes", se refere a uma "epistemologia da douta ignorância", isto é, levar ao máximo à consciência da incompletude de cada saber por meio do "trabalho de tradução" - procedimento de busca de proporção e correspondência entre os saberes. Dizendo de outra maneira, esse seria um tipo de procedimento capaz de criar uma compreensão mútua entre experiências possíveis e disponíveis (ALVES, SEMINOTTI, DE JESUS, 2015), sem destituir as especificidades de cada uma. "Esse tipo de operação se contrapõe a uma teoria geral global, que busca dar conta da diversidade de experiências sociais", conforme Santos (2010).

Dessa forma, o objetivo pautado no pensamento descolonial, é o exercício de expandir modos de perceber e habitar o próprio corpo, questionar os modelos possuidores, em seu âmago, de uma exclusão das diversidades, singularidades e do pluralismo. Ou seja, problematizar discursos instituídos pelo eurocentrismo sobre o dispositivo chamado amor se apresenta como um movimento de construção de outras formas de experienciar e viver. Torna se, portanto, vital provocar um olhar crítico na tentativa de reaprender sentidos não coloniais para os fenômenos amorosos, intrínsecos às relações humanas. Desafia-se, portanto, o que se faz familiar e aquilo que está pautado como verdade universalista.

Por conseguinte, ao tentar produzir um olhar atento e sensível às forças instituintes de modelos de relacionamentos não coloniais, percebemos a complexidade do tema. E justamente pelas riquezas de modalidades existenciais para tal fenômeno, se torna fundamental criar condições de possibilidades para experienciar os encontros a partir de discursividades amorosas contra-hegemônicas. Ou seja, é imprescindível o reconhecimento da existência da multiplicidade de modos de produção de razão, diferentes racionalidades, e das abundantes especificidades de experienciar o amor. É necessário compreender as relações constituintes de determinadas discursividades, a partir da noção de incompletude de cada saber, relacionada à busca 
pela correspondência e/ou complementaridade entre conhecimentos; e da noção de temporalidade e de espacialidade dos saberes, ou seja, a compreensão de que cada conhecimento corresponde a interesses e necessidades relativas a determinado momento, de determinado grupo, coletividade, ou sociedade (ALVES; SEMINOTTI; DE JESUS, 2015).

Sendo assim, é fundamental exercitar o corpo para conhecer cada vez mais o que podemos e o que ainda não podemos, no que tange às concepções pretensiosamente "ideais". Ao reconhecer a legitimidade de diferentes racionalidades e existências, estamos a combater a noção de humano produzida por aspirações coloniais, para criar diferentes formas de vida, e afirmar a complexidade dos dissidentes modos de (re)existir amorosamente no contemporâneo. Portanto, com esse tipo de ética, emergem proposições para expandirmos a cosmopercepção (OYEWÙMI, 2017) sobre a realidade, os corpos, as matérias, as espiritualidades, assim como sobre a produção de outras narrativas do amor que possam vir a estimular a fabricação de novas relações, conexões e alianças possíveis.

\section{Referências}

ALVES, Míriam; SEMINOTTI, Nedio; DE JESUS, Jayro, P. Conhecimentos e verdades: racionalidades em questão! In: SILVA, Leonardo Machado da; MORAES, Maria Lúcia Andreoli de. (orgs.). Psicologia \& questão! In: SILVA, Leonardo Machado da; MORA
espiritualidade. Porto Alegre: EDIPUCRS, 2015.

DELEUZE, Gilles. Dois regimes de loucos: textos e entrevistas. (1975-1995) Tradução de Guilherme Ivo. São Paulo: Editora 34, 2016. (Coleção TRANS)

FEYERABEND, Paul Karl. A Conquista da abundância: uma história da abstração versus a riqueza do ser São Leopoldo: UNISINOS, 2006.

FOUCAULT, Michel. História da sexualidade 2: o uso dos prazeres. Rio de Janeiro: Graal, 2012.

FOUCAULT, Michel. Subjetividade e Verdade. São Paulo: WMF Martins Fontes, 2016.

FUGANTI, Luis A. Saúde, desejo e pensamento. São Paulo: Hucitec, 2008.

KASHINDI, Jean Bosco Kakozi. Ubuntu como ética africana, humanista e inclusiva. Cadernos IHUideias. UNISINOS, ano 15, v. 15, n. 254, p.4-20, 2017.

MALDONADO-TORRES, Nelson. Sobre la colonialidad del ser: contribuciones al desarrollo de un concepto. In: CASTRO-GÓMEZ, Santiago; GROSFOGUEL, Ramón (orgs.). El giro decolonial: reflexiones para una diversidad epistémica más allá del capitalismo global. Bogotá: Siglo del Hombre Editores; Universidad Central, de Estudios Sociales Contemporáneos y Pontificia Universidad Javeriana, Instituto Pensar 2007. p. 127-168.

MIGNOLO, Walter. Desobediência epistêmica: a opção descolonial e o significado de identidade em política. Cadernos de Letras da UFF. Dossiê: Literatura, língua e identidade, n. 34, p. 287-324, 2008.
MIGNOLO, Walter. El pensamiento Decolonial: Desprendimiento y apertura. In: CASTRO GÓMEZ, Santiago GROSFOGUEL, Ramón (orgs.). El giro decolonial: reflexiones para una diversidad epistémica más allá del capitalismo global. Bogotá: Siglo del Hombre Editores; Universidad Central, de Estudios Sociales Contemporáneos y Pontificia Universidad Javeriana, Instituto Pensar, 2007. p. 25-47.

OYEWÙMI, Oyèrónké. La invención de las mujeres. Una perspectiva africana sobre los discursos occidentales del género. Bogotá: editorial en la frontera, 2017.

QUIJANO, Aníbal. Colonialidade do poder e classificação social. In: SANTOS, Boaventura de Sousa; MENESES, Maria Paula (org.). Epistemologias do Sul. São Paulo: Cortez, 2010. p. 73-118.

QUIJANO, Aníbal. Colonialidad y Modernidad/Racionalidad. Perú Indígena, Lima, v.13, n.29 p. 11-21, 1991.

PLATÃO. 0 Banquete. Belém: UFPA, 2011.

SANTOS, Boaventura de Sousa. Para além do pensamento abissal: das linhas globais a uma ecologia de saberes. In: SANTOS, Boaventura de Sousa; MENESES, Maria Paula (org.). Epistemologias do Sul. São Paulo: Cortez, 2010. p.31-83.

SHOPKE, Regina. Dicionário filosófico: conceitos fundamentais. São Paulo: Martins Fontes, 2010.

SOMÉ, Sobonfu. 0 espírito da Intimidade, Ensinamentos Ancestrais Africanos sobre maneiras de se relacionar. São Paulo: Odysseus, 2007. 


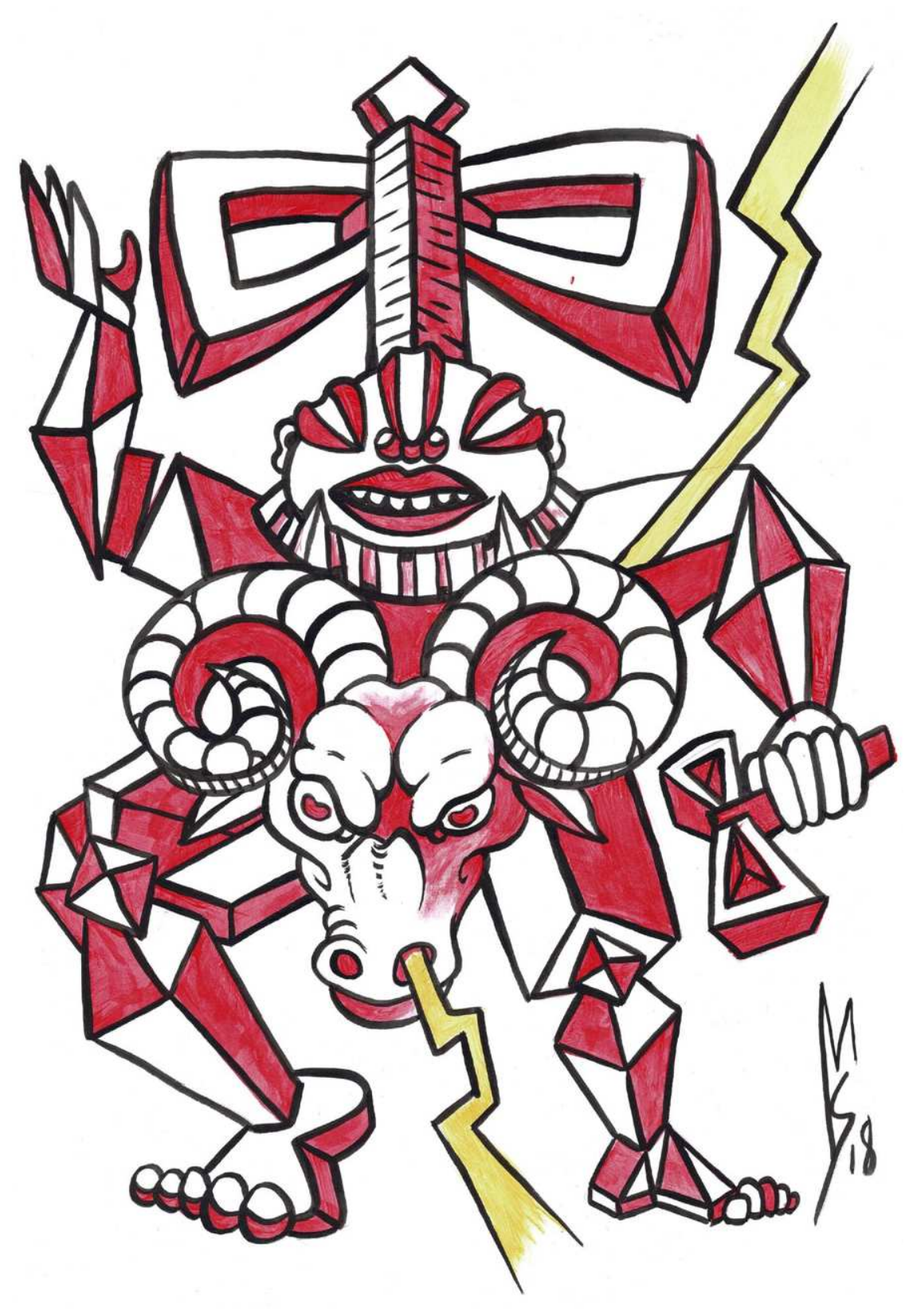

\section{Sàngón ${ }^{28}$}

Ele é Rei, $O b a !$

Na dinâmica social e cosmológica negro-africana tem a prerrogativa biomítica da justiça. Na diáspora, assume a função da justiça reparadora. Está ligado ao princípio físico e fenomenológico do fogo, dos rios dos trovões.

0 mistério das árvores também o constitui. Vermelho, branco, vermelho e branco.

Oșé-Șàngó - grande transmissor de àșe. Possui a função genitora masculina. Alááfin - dinastia, corrente de vida ininterrupta Oba de Ọyó - aquele que assegura a expansão da linhagem, a expansão do reino. Káwó Kábị́sílẹ̣!

28 Oríkì (louvação) para Șàngó, construído a partir das obras: "Agadá: dinâmica da civilização africano-brasileira”, de Marco Aurólio Luz (2000); “Os Nàrê e a Morte: "Pàde Àsèsè e o culto Égun na Bahia”, de Juana Elbein dos Santos (2012); e “Dicionário yorubá-português", de José Beniste (2011). 
AFROTEOLOGIA DO ORÒ29

Hendrix Silveira

Introdução

A relação entre a teologia e a filosofia, assim como as demais ciências, deve ser dialógica. Entendo que a teologia não pode ser o princípio e o fim em si mesma. Dialogando com as demais ciências e com a filosofia, a teologia se torna fértil de sentidos, o que fortalece nossa fé de forma a intelectualizá-la. Agostinho de Hipona fez isso ao se debruçar sobre Platão, e Tomás de Aquino, ao estudar Aristóteles. Mas se, neste sentido, a teologia enquanto área acadêmica é um grande guarda-chuva que pode abrigar outras ciências, por outro lado, costuma ser menosprezada por elas.

Já ouvi relatos de que professores universitários de outras áreas teriam apontado erroneamente, saliento, que a teologia sequer deveria receber recursos governamentais, uma vez que trataria de doutrinas e não de conhecimento científico. A despeito disso, o Ministério da Educação brasileiro e seus institutos de fomento à pesquisa reconhecem a teologia como área acadêmica e também algumas instituições formadoras. Da mesma forma, a profissão de teólogo é reconhecida pelos órgãos federais como ocupação formal no mercado de trabalho brasileiro.

Por outro lado, há dentro da teologia as ideias recorrentes de que as tradições de matriz africana ${ }^{30}$ são objetos de pesquisa e não sujeitos, que estas tradições não possuem uma teologia ou ainda que esta é incompleta, como deduzem Franziska C. Rehbein (1985) e Raimundo Cintra (1985). Em meu livro "Não somos filhos sem pais" (SILVEIRA, 2020), pude contestar tais afirmações e legitimar a teologia dessas tradições como afroteologia.

Afroteologia foi o termo que empreguei para definir de forma mais conceitual a teologia das tradições de matriz africana. 0 senso comum costuma atribuir à teologia uma natureza exclusivamente cristã, ignorando que todas as tradições 29 Este artigo é uma adaptação de parte de um dos capítulos de minha tese de doutorado em Teologia, defendida em 2019, intitulada "Afroteologia: construindo uma teologia das tradições de matriz africana" orientada pelo Prof. Dr. Oneide Bobsin e que foi indicada ao prêmio de melhor tese da CAPES na área. 30 Prefiro usar a expressão "Tradições de Matriz Africana" para definir todas as manifestações da espicomo outra categoria de seres espirituais. Sobre isso já discorri em outros trabalhos. religiosas possuem uma teologia própria. 0 cristianismo transformou sua teologia em uma disciplina formal. Outras tradições religiosas - como o judaísmo, o islamismo e o hinduísmo -, que têm como revelação um livro sagrado, fizeram o mesmo. Essas teologias são reconhecidas pelo ocidente eurocêntrico, mas as teologias das espiritualidades cuja revelação está na tradição oral sequer são entendidas como tal. No tocante a este ponto, o racismo e a afroteofobia (racismo religioso) têm contribuído para a negação da existência de uma teologia das tradições de matriz africana. 0 mais ferrenho denunciador disto foi o professor Jayro Pereira de Jesus ${ }^{31}$, o primeiro afroteólogo acadêmico brasileiro, que viajou o Brasil todo para reafirmar a existência dessa teologia e que tive a oportunidade de conviver por quase dez anos.

A afroteologia brota da experiência espiritual nas tradições de matriz africana. Ela parte de princípios próprios da percepção de mundo ancestral africana. Essa percepção confere à afroteologia uma relação singular entre os sujeitos e os signos que os cercam, empregando sentidos próprios, seguindo a lógica cultural das observações desse povo sobre o mundo visível e o invisível.

Tenho chamado a Revelação Divina nas tradições de matriz africana de Ọgọ́n Méfà (Seis Sabedorias) ou corpus oral epistêmico das tradições de matriz africana. Identifiquei Ifá, Oríkì, Adúrà, Orin, Òwe e Orò como sendo partes deste corpus oral sagrado. Os Oríkì sãoum tipo de louvação, uma série de versos que exaltam as qualidades das divindades, dos ancestrais e também são usados para dignificar pessoas ilustres e importantes para suas comunidades como reis, portadores de cargos ou títulos e chefes de família. Adúrà são as preces entoadas em forma de cantigas, porém sem o acompanhamento de instrumentos musicais. São empregados como invocações à presença imaterial dos Òrịsà. Orin são os cânticos sagrados dedicados aos Òrìșà e que lhes servem de evocação para a manifestação em seus descendentes míticos. Assim como os adúrà, também servem de invocação para a força imaterial das divindades. Neles estão relatadas histórias sobre as divindades que nos revelam muito de sua natureza. Nestes cânticos há o acompanhamento de instrumentos musicais tocados por uma orquestra sagrada liderada pelo sacerdote do tambor, o Alágbe.

Cada um destes Ogbọ́n foi objeto de minha pesquisa no doutorado, mas neste artigo tratarei especificamente dos Orò, os ritos e liturgias das tradições de matriz 31 Jayro Pereira de Jesus (Olorodè ògyán kalafò) é licenciado em Ciências Religiosas (2000) e bacharel em Teologia (2006) pela PUCPR, atuou como Conselheiro Técnico do Conselho de Desenvolvimento EcoAfricana, e diretor geral da Escola de Filosofia e Teologia Afrocentrada. 
africana, com ênfase no Batuque, tradição que vivencio. Assim este trabalho tem como objetivo atribuir sentidos e propósitos aos Orò a partir de uma reflexão afroteológica.

Como método foi utilizado a exunêutica. Este método foi desenvolvido por mim a partir do mestrado e aprofundado durante o doutorado. Consiste na observação e interpretação "desde dentro" das tradições de matriz africana, convergindo alguns conceitos afins como nos Estudos Culturais, Estudos Decoloniais, Teologia da Libertação, Marxismo Cultural, Pedagogia do Oprimido, Pensamento Pós-Abissal e Afrocentricidade. De forma alguma farei aqui descrições densas dos ritos, pois não é esta a proposta. Este não é um trabalho antropológico e desejo que os ritos sejam preservados o máximo possível, pois, como diz o provérbio: "Biri-biri bò wọn lójú ògbẹri nko mo Màrìwo. Trevas cobrem seus olhos, o não iniciado não pode conhecer o mistério do Màrìwò" (SANTOS, 2002, p. 21).

Assim, quando os ritos forem de alguma forma detalhados, será apenas para que se faça a análise afroteológica sobre eles, de forma a auxiliar na sua compreensão. Buscarei nestes ritos semelhanças entre as diferentes tradições, entendendo que essas diferenças são apenas na forma, nunca nos propósitos. Por fim, apresento minhas considerações finais.

Darei ênfase a três ritos neste trabalho, pois estão presentes em quase todas as tradições de matriz africana, seja as que foram estruturadas na diáspora, ou mesmo as originárias do próprio continente africano: o Borí, o ờsẹ́ e o Ìsinkú.

Borí $^{3233}$

O Borí é um rito de (re)nascimento. Coloco o "re" entre parênteses porque para as tradições de matriz africana o ser humano nasce duas vezes: o parto biológico,

32 A forma escrita deste termo está propositalmente em desacordo com a literatura antropológica atual, pois tenho refletido de modo diverso dos pesquisadores dessa área. A maioria - que se repete sem se aprofundar no sentido da palavra - apresenta a escrita bơrí ou ainda eborri intentando criar uma palavra que expresse o que acreditam significar "alimento à cabeça (ebọ + ori). No entanto, levanto de sua pronúnci: borí pronúncia "bóri", que é bem diferente da pronúncia corrente em todo onras causa própria África: "bôrí". Isto pode indicar um significa do diferente bi + orí, o nascer ou renascer da cabeça. 330 rito de borí sempre foi entendido no Batuque como um rito de vinculação ao Òrìs̀̀ e de fortalecimento da cabeca 0 que acaba por ser entendido pelos vivenciadores e vivenciadoras como uma chasse ou categoria de iniciacão. Mas para o Candomblé, a iniciação se dá apenas quando a pessoa realiza "raspagem" rito de vinculacão com o assentamento de Òrișà̀ Para estes, o borí é apenas uma oferenda de fortalecimento que não cria laços com os Òrì̦̀à nem inclui quem o realiza no quadro uma oferenda de fortalecimento que não cria laços com os Orișă, nem inclui quem o realiza no quadro de membros da borí que promove, no Candomblé, um entendimento mais superficial e pragmático deste importante rito. advindo do ventre de sua mãe e o nascimento espiritual ritualizado no Borí. De acordo com a cosmopercepção africana ${ }^{34}$, o nascimento de uma pessoa só se completa após concluído o rito de Borí, pois este rito reúne o indivíduo ao cosmo, algo rompido no momento do corte do cordão umbilical.

De acordo com a tradição oral, este é o rito mais importante, pois quem o realiza estabelece um vínculo com o seu Òrìsà, garantindo um relacionamento mais íntimo e profundo. Este rito também é escatológico, pois garante longevidade e uma pós-vida plena, garantida na ancestralização.

A feitura de Borí está relacionada à noção ontológica de humanidade, uma vez que somos seres antropoteogônicos ${ }^{35}$, ou seja, possuímos uma origem biológica e teológica. A cabeça é considerada a parte do corpo mais importante, o que é comprovado pela própria natureza, ao ser a primeira a surgir no momento do nascimento, e é a sede do conhecimento, da inteligência, da individualidade, da sabedoria e da razão, pois possui todas as ferramentas para que o ser humano os adquira (olhos, ouvidos, nariz, boca) (BENISTE, 2008).

$\mathrm{O}$ ara (corpo) enquanto elemento físico está teologicamente relacionado à criação divina. A constituição do ser humano enquanto ser biológico está relacionada com a contribuição dos Òrìșà na construção de seu DNA. Ou seja, quando o ser humano é criado, um Òrị̀à contribui para completar o código do DNA dessa pessoa, que assim passa a estar diretamente relacionada a ele; se torna seu descendente mítico. É por isso que percebemos semelhanças físicas e arquetípicas entre filhos de um mesmo Òrìșà. A isso convencionamos chamar de orixalidade. Mas além da orixalidade também há a ancestralidade, ou seja, a contribuição de nossos ancestrais biológicos para a construção de nosso corpo enquanto seres biológicos. Então, somos frutos de uma contribuição mítica e ancestrálica na nossa concepção. Juana Elbein dos Santos (2002) explica bem isso:

34 Em sua obra, a pesquisadora nigeriana Oyèrónkẹ́ Oyèwùmí (1997)faz uma crítica aos usos universais do conceito de cosmovisão. Ela cunhou a expressã̃o world-sense para marcar a diferença, em relação à percepção da realidade, entre os yorùbá, da "cosmovisão" ou "visão de mundo" (worldview) utilizada no Ocidente. Sua crítica aponta para o fato de que ao privilegiar a "visão" no contexto de apropriação cognitiva das coisas do mundo, o Ocidente valoriza o que aos olhos parece ser diferente, o que propagou as discriminações de todo o tipo. Mas, segundo ela, os africanos percebem o mundo por meio de todos os sentidos e năo apenas a visão, daí o world-senir o "cosmosenaçao". No e "cosmo, Wanderson F. Nascique a palavra sense é mais abrangente.

35 Expressão criada pelo afroteólogo Jayro Pereira de Jesus (informação verbal). 
Se os pais e antepassados são os genitores humanos, os òrì̀sà são os genitores divinos; um indivíduo será "descendente" de um òrịsà que considerará seu "pai" - Baba mi - ou sua "mãe" - İyá mi - de cuja matéria simbólica - água, terra, árvore, fogo, etc. - ele será um pedaço. Assim como nossos pais são nossos criadores e ancestres concretos e reais, os òrị̀à são nossos criadores simbólicos e espirituais, nossos ancestres divinos (SANTOS, 2002, p. 103).

Outra parte do corpo que integra essa percepção de mundo são os membros inferiores (ẹẹ̀). Wándé Abímbọ́lá (1981, p. 17) aponta os ẹsè como "uma parte vital da personalidade humana" e completa:

Esè̀, para os iorubás, é o símbolo do poder e atividade. Ele é, entretanto, o elemento que habilita o homem para lutar e agir adequadamente na vida, para que ele possa realizar o que foi designado para ele, pela escolha do Orí. Como Orí, eseè é reconhecido como um òrìsà que precisa ser cuidado, na intenção de conseguir o sucesso. Por isso, quando um homem faz um sacrifício para seu Orí, parte do sacrifício é também oferecido para ẹsẹ. (ABÍMBớLÁ, 1981, p. 17)

Sob o ponto de vista espiritual, orí (cabeça), ara (corpo) e esẹ̀ (pernas) são partes constituintes da personalidade humana que se inter-relacionam com o meio físico e o espiritual ao mesmo tempo. Isto nos constitui como seres antropoteogônicos, ou seja, somos criados como seres biológicos e hierofânicos, pois nossos corpos também são uma manifestação do sagrado.

Basicamente o nosso ser espiritual possui “múltiplas almas” (BASCOM, 1960), mas neste texto abordarei brevemente cinco delas: òjiji, ẹmí, èémí, orí-ínú e eseẹ̀.

Òjiji é a sombra. Ela surge no nascimento e não tem nenhuma função especial senão a de acompanhar o corpo. Ela "não possui substância e não requer nenhuma nutrição", por isso não são realizados rituais a ela, contudo, segundo alguns é ela que viaja pelo mundo dos sonhos quando estamos dormindo e caso não retorne a pessoa jamais acordará. (BASCOM, 1960, p. 4) Para outros, essa é a função do Ẹmí. A sombra é o símbolo do "doble espiritual", o ẹnikéjii que reside no ọ̀run (SANTOS, 2002, p. 205; 216).

Ėmí é geralmente traduzido como "alma" em português e em inglês "soul". É a expressão simbólica dos sentimentos e emoções, que no plano físico está 36 'Enikéjì é o nome dado ao duplo que vive no ọrun. Todos os seres têm o seu 'outro lado' exatamente como é aqui na Terra; quando são feitas obrigações, as oferendas visam atingir o ẹnikéji das pessoas. Ẹni - pessoa, kéji - segunda." (BENISTE, 2008, p. 181) representado pelo coração (ọkàn). Èémí é o espírito sagrado, o ar insuflado por Olódùmarè em nossas narinas logo ao nascer, que nos dá vida e é representado pela respiração. Tanto William Bascom (1960) quanto Wándé Abímbọ́lá (1981) fundem essas duas "almas" em uma só e a chamam unicamente de Ėmí, cuja manifestação física é a respiração; é a própria força vital que garante a vida e permite desenvolver atividades laborais. 0 Ẹmí se nutre dos alimentos que consumimos - se não comermos ele irá embora, extinguindo nossa vida no Ayé -, mas também se fortalece com parte das oferendas sacrificiais ao Orí. De acordo com William Bascom (1960, p. 4), há dúvidas entre seus informantes sobre qual das "almas" viaja nos sonhos:

De acordo com os informantes de Meko, é a respiração que deixa o corpo durante sono, visitando em sonhos, lugares distantes. Quando a pessoa desperta ele pode dizer sobre as coisas que ela viu e fez em outras cidades, considerando que outros saibam que o seu corpo permaneceu no mesmo quarto com eles. Quando a respiração for longe, não se pode acordar depressa esta pessoa [...]. Os informantes de Ifé concordaram que é a respiração que parte do corpo em sonhos, mas nos asseguram que não há perigo de despertar uma pessoa quando está longe, desde que ela retorne imediatamente. Por outro lado, um informante de Iganna manteve que é a sombra que viaja em sonhos, argumentando que se pode ver uma pessoa dormindo respirando normalmente, e que se a respiração deixar uma pessoa ou sua sombra não retornar, ele morrerá.

Para Wándé Abímbọ́lá (1981), na concepção da criação humana, Òșàálá criou os corpos humanos ( $a r a$ ) feitos da massa/lama primordial, mas são estáticos, enrijecidos. Ele leva esses corpos a Olódùmarè, que lhes dá o Ẹmí, a alma, que reside no ọkàn, o coração físico que bate indicando que aquele ser está vivo. Ajàlá, o oleiro, é a divindade responsável pela construção das cabeças, não a cabeça física - esta quem faz é Òsàálá -, mas a cabeça mítica, o orí-ínú, a "cabeça de dentro", ou seja, o centro mítico de nossa existência individualizada.

Orí é a essência da sorte e a mais importante força responsável pelo sucesso ou fracasso humano. Além disso, Orí é a divindade pessoal que governa a vida e se comunica, em prol do indivíduo, com as demais divindades. Qualquer coisa que não tenha sido sancionada pelo Orí de uma pessoa, não pode ser aprovado pelas divindades (ABÍMBỌ́LÁ, 1975, p. 2). 
É no orí que está determinado nosso "projeto mítico-social"37, que muitas vezes é entendido como destino, o Odù, falado anteriormente, por isso ele também é chamado de ìpọnrí ou ìpín. Já o ẹsè, como disse antes, é o "símbolo do poder e atividade" da possibilidade de realização das designações do Orí. (ABÍMBọ́LÁ, 1981, p. 4) Todos estes elementos estão representados no Igbá-Orí que recebe oferendas de tempos em tempos através do rito de Borí.

Se por um lado o Orí-inú do àiyé reside no corpo, na cabeça de cada indivíduo, sua contraparte, o Orí-òrun é simbolizado materialmente e venerado. Durante as cerimonias de Borí $(=$ Bo + orí = adorar a cabeça) ele é invocado e os sacrifícios são oferecidos ao Orí-inú, sobre a cabeça da pessoa, e a Igbá-orí, cabaça simbólica que representa sua contraparte no òrun. (SANTOS, 2002, p. 205)

Em África, o Òrìsà é uma divindade que pertence à coletividade de uma família, bairro, aldeia ou reino, por isso o culto a Orí é importante, pois é ele que individualiza cada ser humano tornando-o único. o Orí é entendido como uma divindade poderosa que define os caminhos dos seres humanos antes mesmo dos próprios Òrìșà. Isto é percebido em um de seus Oríkì, narrado no Odù Ògúndá Méjì (ABÍMBọ́LÁ, 1981, p. 11):

\author{
Orí, pẹ̀lẹ́ \\ Atèté níran. \\ Atètè gbe ni kòòșà \\ Kò sóòșà tíi dá nií gbè \\ Lẹ́yín orí ếni \\ Orí, pẹlé \\ Orí àbíyè \\ Éni orí bá gbeboọ rẹ \\ Kó yọ̀ sẹsè̀ \\ Orí, eu te saúdo
}

És aquele que sempre se lembra de nós

És o que abençoa antes de qualquer òrișà

37 Expressão criada pelo afroteólgo Jayro Pereira de Jesus (informação verbal).
Nenhum òrìsà abençoa uma pessoa

Sem o consentimento de seu Orí

Orí, eu te saúdo

És quem permite que as crianças nasçam vivas

Aquele cujo sacrifício é aceito por seu Orí

Se alegrará abundantemente

Então temos, na concepçãoafricana, os Òrìșà como divindades representativas da espiritualidade coletiva e o Orí como representativo da espiritualidade individual. Contudo, no Brasil, Òrìsà e Orí se fundem na concepção de espiritualidade individual e coletiva, pois se lá um único òrìșà é o conector de toda uma comunidade, clã ou família - o que também ocorre aqui -, na diáspora vários Òrìsà se convergem na constituição de uma única pessoa.

Se tornando uma divindade pessoal, o Òrìșà se relaciona com o orí, o ara e o esệ. Assim temos um Òrìșà principal que reside e rege a cabeça (orí) do iniciado, outro que rege o corpo (ara) e outro que rege as pernas e pés (eseẹ). Muitas vezes, na tradição do Batuque, as pernas e os pés são separados por acreditarem ser de categorias diferentes, ficando os pés a cargo exclusivo do Bara, um Èșù específico e individual para cada pessoa.

O que dinamiza a relação entre todos estes elementos é o poder de Èșù, cuja função é a de transmissor do Àșe, o poder divino de criação e manutenção da vida. Como ele é o intercessor de tudo, Èșù também se estabelece como o mediador das forças que agem no corpo, um agente espiritual que garante a funcionalidade de todos os órgãos do corpo humano, além de seu potencial espiritual. Talvez por isso que Juana Elbein dos Santos (2002, p. 181) o considera como Obara, um epíteto para o Èșù, que é o "Rei do corpo" (Ọa + ara).

É durante o rito de Borí que, no Batuque, o orí, o ara e o esẹ recebem oferendas sacrificiais. A longevidade e a pós-vida garantidas na ancestralização são asseguradas pelo rito escatológico. A feitura de Borí está intimamente relacionada à noção ontológica de humanidade e deve ser refeita todos os anos como num contrato mítico entre a pessoa, as divindades envolvidas na sua constituição e Ìkú, a Morte.

Ao observar as liturgias das tradições de matriz africana é perfeitamente perceptível o simbolismo sexual que dela emerge. Isso é aparente nas principais 
liturgias como o borí que, a partir da análise, figuram como representações simbólicas de um ato sexual, elemento da ordem cósmica; uma hierogamia ${ }^{38}$. A teologia aqui é de que o ato sexual é gerador de vida, logo, representações simbólicas desse ato se apropriam de forma teológica de sua força que, então, será direcionada para a intenção do ritual.

No Batuque, tradição de matriz africana que vivencio e estudo, podemos perceber essas nuances nitidamente. Na concepção afroteológica, o espaço sagrado onde se destinam os rituais imolatórios de iniciação, que no Batuque é o pejí ou "quarto de Òrìșà", ou ainda "quarto de santo"; e no Candomblé é o hunkọ ou camarinha, é um verdadeiro útero mítico. Ali são realizados os ritos de borí.

o borí, reforço, é um ritual iniciático de renascimento e cosmologização que garante a individuação da pessoa diante do coletivo em que ela está incluída, possibilitando a construção de sua identidade; também a reintegra ao cosmo, laço este rompido com o corte do cordão umbilical no seu nascimento biológico. 0 borí garante ao indivíduo plena integração à comunidade, estabelecendo vínculos familiares tanto com as divindades como com os outros membros do grupo; e ainda mantém as estruturas sociais e hierárquicas dentro da comunidade, como aponta Jay (1997, p. 99-100):

O ritual sacrificial poderá servir, assim, de várias maneiras, como garantia e, por conseguinte, como meio para criar uma descendência patrilinear, não como um fato da natureza, mas como princípio de organização social. Todo a vez que o sacrifício atuar dessa maneira realizadora, ele será aquilo que Tomás de Aquino denominou de "sinal eficaz", isto é, que produz aquilo que ele significa: neste caso, a incorporação como membro da descendência paterna (Summa Theologica, III, q. 62;1). Segundo Tomás de Aquino, como também segundo os sacrificadores tribais, a atuação eficaz de um ato simbólico dependerá, é claro, indiretamente da existência de outras estruturas (social, religiosa, linguística, legal, etc.). Em outras palavras, o sacrifício nunca "causaria" a participação como membro de uma linhagem paterna lá onde não existissem linhagens paternas.

É no centro do pejí/hunkọ/útero que o neófito é colocado sentado no chão ou sobre uma esteira, representação da terra. No linguajar do Batuque há a expressão "fazer chão" ou "ir pro chão", que significa cumprir o rito de borí, ficando recluso por 38 Para Mircea Eliade (1992, p.31), o resultado da hierogamia, ou seja, do ato sexual primordial ou divino, é a criação cósmica. alguns dias no terreiro, devendo dormir no chão, sobre um colchonete. 0 uso de um colchonete no lugar da esteira, corrente no Candomblé, se dá provavelmente devido às baixas temperaturas do território gaúcho. Na maioria das tradições religiosas não patriarcais a terra é entendida como uma divindade feminina associada ao poder gerador de vida. Este entendimento se dá pela percepção material do crescimento das plantas que brotam do "ventre" da terra. 0 mundo natural e o espiritual estão sempre conectados. Para os yorùbá, o chão (Ilè) não é uma divindade, mas sim a morada de Onílè, uma divindade feminina que ganhou de Olódùmarè o governo da terra (PRANDI, 2001. p. 410-415).

No Batuque, além de o neófito ficar sentado no chão, parte do àșorò ${ }^{39}$ é recolhido numa vasilha com água chamada de ệo. Esta água é despachada no solo, seguindo alguns preceitos, alimentando a terra/Onílè̀. 0 chão está presente em todos os momentos do (re)nascimento do indivíduo. A saudação mais simbólica nas tradições de matriz africana consiste na pessoa se deitar ao solo, com o corpo estirado. Mais uma vez notamos aqui a importância do chão como símbolo feminino: mulheres deitam de lado e viram para o outro, sem encostar o ventre no chão, pois isso poderia ser entendido como se ela estivesse ofertando seu útero à Onílẹ. Já os homens deitam de bruços, com seu órgão genital encostando no chão, pois não há problema de se oferecer o poder gerador masculino à Onílè. A mesma teologia é pensada no tocante à morte dos iniciados. Os corpos dos mortos são enterrados para que assim, no "útero da terra", possam renascer no outro mundo.

No colo do iniciante é depositado o ìgbá, um grande alguidar de barro, espécie de vasilha onde o fundo é muito mais estreito que a borda, mas também pode ser uma grande bacia de louça ágata; assim como o peji, todas as vasilhas, vasos, panelas e objetos cuja forma pode conter algo são representações simbólicas do útero que contém a força e poder de fertilidade feminina. Dentro dele é que ficam certos implementos que serão sacralizados.

Temos aqui dois elementos cruciais para a geração de vida: a faca/falo e o alguidar/útero. É a fusão de ambos que garante a geração, manutenção e continuidade da vida. E isso se dá pelo àșorò, o sangue que verte dos animais sacralizados e que carrega a sua força vital e, ao mesmo tempo, é a representação simbólica do sêmen que fecunda. 39 Àșorò é o termo empregado no Batuque especificamente para o sangue dos animais sacralizados, nunca empregado para qualquer outro tipo de sangue (èjè̀). Identifico duas possibilidades sobre a origem cando "nós fazemos o ritual". No Candomblé o termo empregado para o sangue das sacralizações é ẹjẹ̀. 
Segundo Eliade (1992. p. 29): "Cada ritual tem um modelo divino, um arquétipo, [...] todos os atos religiosos são considerados como tendo sido fundados pelos deuses, pelos heróis civilizadores, ou por ancestrais míticos". Assim, os ritos imolatórios são a representação ou representificação, no sentido de "tornar presente novamente" os eventos contidos nas histórias sagradas:

Um sacrifício, por exemplo, não só reproduz com exatidão o sacrifício original, revelado por um deus ab origine, no princípio dos tempos, mas também é realizado naquele mesmo momento mítico primordial; em outras palavras, cada sacrifício realizado repete o sacrifício inicial e coincide com ele (ELIADE, 1992, p. 38).

É o que ocorre nas tradições de matriz africana. De acordo com a tradição oral e amplamente registrada na literatura antropológica (VERGER, 1997; BENISTE, 2006, 2008; SANTOS, 2002; PRANDI, 2001), Òșàálá recebeu de Olódùmarè a incumbência de criar o mundo. Para esse fim, ganhou dEle o "saco da criação" que continha um punhado de terra, uma galinha e um pombo. Depois de uma série de aventuras (ou desventuras) narradas nas mais variadas versões deste itán (história sagrada), Òṣàálá - por vezes chamado de Ọbàtálá em algumas versões ou Odùduwà em outras - chega ao pântano primordial que era o próprio caos e derrama a terra nesse caldo formando um montículo, colocando a galinha e o pombo a ciscar. Este ato fez com que o montículo se expandisse ao ponto de se tornar toda a Terra.

Embora a criação do mundo não tenha se dado em função de um ritual imolatório, percebe-se a importância dada à galinha (adiẹ) e ao pombo (ẹiyẹeẹ) para a criação e expansão do mundo. Nos ritos de borí, os principais animais imolados são o pombo e a galinha ou galo. Durante esse processo, o àșorò desses animais é vertido sobre o orí do neófito, esperando que isso o cosmologize, amplie, expanda seus sentidos e sua espiritualidade como um ser individual e único. Isto também é observado quando, na continuidade do processo iniciático, os pombos são temperados e assados, regados com um pouquinho de mel (símbolo natural de doçura e, por extensão, coisas boas, agradáveis) e entregue para os iniciados comerem. Ao contrário do que acontece com a galinha que é servida em pratos típicos para toda a comunidade no banquete comunal, o pombo nutre tão somente os iniciados, reforçando seu papel de individuação. A importância do pombo está alicerçada numa simbologia que "representa honra, prosperidade e longa vida. É o que se espera daquele que o use nos sacrifícios. A sua serenidade quando voa, sua aparência e elegância de movimento atribuem-lhe uma espécie de santidade" (BENISTE, 2008, p. 307). 0 pombo voa alto, o que é símbolo para a expansão, a dinamização e a cosmologização do orí.

Retomando o sentido hierogâmico que apontei nestes rituais, pode-se ver o òbe/falo que faz verter o àșorò/sêmen que fecunda o igbá/útero que aguarda fértil de implementos que então se tornarão cheios de vida. 0 mesmo acontece com o iniciado, que será entendido a partir daí como um (re)nascido, uma (nova) pessoa, cheia de vida e plenamente humanizada. Da mesma forma que um nascituro está coberto com o sangue de sua mãe biológica, o neófito (re)nasce coberto pelo sangue sagrado (àșorò), que assim se torna símbolo de seu (re)nascimento como uma (nova) pessoa para a tradição; se inscreve num projeto de humanidade que o individualiza; se torna parte da comunidade por laços de consanguinidade mítica, descendência do Àșẹ; e se confirma a sua ascendência mítica com o Òrìsà ao qual foi consagrado.

Na sequência da liturgia batuqueira, o neófito, ainda dentro do pejí/útero, é erguido pelo Bàbálórișà ou İyálórìșà e pelo padrinho ou madrinha, um de cada lado, como se fossem os parteiros deste novo ser. Em seguida ele é conduzido até a porta do pejí/útero numa clara alusão a um parto. Ao final desse processo o iniciado será considerado um, com os Òrìsà e com a comunidade. Será um ser humano completo.

Os ritos de renovação e restituição são chamados de Ộsẹ. Nos dias de hoje, esta palavra define a semana yorùbá de sete dias ${ }^{40}$, mas antes da colonização a semana possuía quatro dias, sendo que cada um deles é consagrado a um Òrìșà. De acordo com Pierre Verger (1997, p. 88), este dia consagrado - que ele chama de "domingo" - também é chamado de Ộsệ. Nenhuma das duas formas está errada já que a semana é um conjunto de dias, sendo que para alguns grupos religiosos geralmente um deles é o de devoção à sua divindade particular. Para os judeus, por exemplo, o shabāté o dia dedicado a Javé, enquanto que para os cristãos é o domingo 40 A semana moderna yorùbá é definida da seguinte forma, de acordo com Beniste (2008): ojọ ajẹ́ - dia do sucesso financeiro (segunda-feira), ojọ́ ìșégun - dia da vitória (terça-feira), ojộ rú - dia da confusão ojó àbáméta - dia das três resoluções (sábado) e ojó ísinmi - dia do descanso (domingo). 
(dies Dominicus, "dia do Senhor"). Neste contexto, o uso da palavra "domingo" por Pierre Verger (1997) refere-se ao dia de dedicação ao culto das divindades. Assim, no dia chamado de ojọ́ Awo, é o dia em que os devotos de ồrúnmilà o cultuam; ojọ́ Ògún é o dia para os devotos do Òriṣà civilizatório; no ojộ́ Jákúta é a vez dos iniciados à Sàngó; e ọjọ Ọbàtálá é o dia consagrado a Òsàálá. Para cada um dos grupos o dia consagrado à devoção de um Òriṣà é o seu domingo.

Seguindo a linha de pensamento de Pierre Verger, há os pequenos "domingos" (Ộsẹ kékeré), onde são renovadas as oferendas incruentas, ou seja, quando se oferecem pratos à base de vegetais como cereais e tubérculos. E os grandes "domingos" (ồsẹ nlá), quando são realizadas procissões, onde o assentamento do Òrìșà é lavado com água da nascente de um rio, e sacralizações acompanhadas de grandes festas coletivas, muitas vezes patrocinadas pelo rei local ou dono de mercado; onde os Òrìșà podem se manifestar em seus neófitos, dançar entre seus descendentes e abençoar todas as pessoas que estiverem presentes.

Os sacerdotes fazem um grande banquete público onde o povo se farta em agradecimento às bênçãos das divindades e de seu descendente vivo, o rei. Os próprios Òrìșà se apresentam na festa: primeiro Èșù se manifesta em oluponán, seu sacerdote; depois vem os outros Òrìsà: Ògún, Șàngó, Ọya e, por fim, Òșàálá. Todos se curvam para receber as benesses dos que vieram do ồrun especialmente para o festejo.

Existem dois grupos bem definidos durante os festejos. Os sacerdotes são saudados com a expressão em yorùbá kabiesi, a mesma saudação aos reis, o que nos mostra a importância desse cargo; e os İyàwórìșà, as "esposas" do òrìșà. Apesar desse nome, os İyàwórìșà, ou na sua forma diminutiva İyàwó, podem ser tanto homens como mulheres. Isto porque o neófito está sujeito ao Òrìsà do qual é consagrado, não tendo nenhuma outra conotação. Os İyàwó são em grande número e foram todos iniciados por um Alàșe. Em alguns casos, o Òrìsà pode se manifestar em vários Ìyàwó ao mesmo tempo; em outros lugares, apesar de todos serem suscetíveis à manifestação do Òrìșà, ele possuirá apenas um.

Mircea Eliade (1992) define que povos e culturas antigas possuem um rito de "renovação do tempo". Este rito reflete a percepção de mundo de que o tempo é cíclico, logo os anos não avançam no tempo, mas se renovam a cada ciclo. "As divisões do tempo são determinadas pelos rituais que orientam a renovação das reservas alimentares, isto é, os rituais que garantem a continuidade da vida da comunidade por inteiro." (ELIADE, 1992, p. 55) Devido ao caráter urbano das tradições afrodiaspóricas, as datas já não coincidem mais com as da colheita como ocorre entre os diferentes povos da África. As datas se tornaram mais dinâmicas, mas o propósito ainda é o mesmo: garantir a subsistência da comunidade por meio do alimento. As grandes festas do Batuque (ẹọ) e as do Candomblé (șiré) são a adaptação a essas condições, daí sempre haver um banquete.

Era comum, em tempos idos, que as pessoas desejosas de que certa festividade acontecesse diziam que esperavam pelo "retorno da festa" e não "pela próxima" como dizemos hoje. Isso demarca a concepção de uma ciclicidade e, por extensão, da renovação do tempo e dos eventos.

O fato essencial é que em toda parte existe uma concepção de final e de começo de um período de tempo, baseada na observação dos ritmos cósmicos e que faz parte de um sistema mais abrangente [...] de regeneração periódica da vida. [...] uma regeneração periódica do tempo pressupõe, de um modo mais ou menos explícito - e, em especial, nas civilizações históricas - uma nova criação, ou seja, uma repetição do ato cosmogônico (ELIADE, 1992, p. 56).

Os ritos de renovação do tempo são importantes justamente porque garantem a continuidade das estruturas conhecidas. Segundo Mircea Eliade (1992), há três aspectos presentes nos ritos de renovação do tempo: as purificações; a demolição dos altares e subsequente reconstrução; os sacrifícios seguidos de festas e banquetes.

No Brasil, muitos dos elementos ritualísticos africanos permaneceram na estruturação dos cultos aos Òrìșà, Vodun e Nkisi, como no Candomblé da Bahia, no Tambor de Mina do Maranhão, no Xangô do Recife, na Macumba do Rio de Janeiro e no Batuque do Rio Grande do Sul. Da mesma forma, conseguimos perceber os três aspectos delineados por Mircea Eliade (1992) nos ritos de Batuque e Candomblé, tanto na forma coletiva quanto individual.

No caso específico do Batuque do Rio Grande do Sul, durante o mês de dezembro são realizadas purificações coletivas nas pessoas da comunidade, tanto iniciadas quanto não iniciadas. Estas purificações, chamadas de "limpeza de final de ano", visam tornar essas pessoas aptas a entrar no novo ano, mesmo que secular, expiadas de suas faltas. "E este é o significado das purificações rituais: uma 
combustão, uma anulação dos pecados e das faltas do indivíduo e da comunidade como um todo" (ELIADE, 1992, p. 57).

A palavra Ọ̀sè permaneceu como um rito anual, embora deturpada pela nova realidade. No Batuque, ọsẹ̀ tem o significado de "limpeza ritual dos assentamentos dos Òrìșà", o que não difere muito da realidade do Candomblé.

Durante o Ồsè batuqueiro - que geralmente ocorre no mês de dezembro, mas pode ser realizado a qualquer tempo - os assentamentos dos Òrìsà são retirados das prateleiras onde estão guardados dentro do pejí. Os òkúta, o coração desses assentamentos e elemento hierofânico do culto, são retirados de suas vasilhas com cuidado e carinho para serem limpos, juntamente com os implementos sagrados que compõem o Igbá. 0 quarto sagrado onde ficam os assentamentos dos Òrìșà pode ser completamente desmanchado, as prateleiras podem ser destruídas e substituídas por novas, as quartinhas esvaziadas, tudo é limpo, deixado como novo. Cortinas e adereços são retirados e trocados por novos. Todo o quarto dos Òrìsà, representação mítica do útero que se renova a cada ciclo menstrual, e que também representa simbolicamente o "centro do mundo" (axis mundi), é rearranjado, deixado como novo, regenerado a cada ano. Os implementos sagrados serão realocados em seus lugares, representação da presença das divindades no mundo.

Por fim, refeito, reconstruído, reorganizado, o pejí está pronto para as renovações anuais das imolações que servirão de repasto ao povo e às divindades na grande festa pública que acolhe iniciados e não iniciados, assim como os Òrìșà que se manifestam em seus İyàwó.

Todos esses elementos completam o ciclo ritual anual garantindo a continuidade da vida e do cosmo. "Cada Ano Novo é considerado como o reinício do tempo, a partir do seu momento inaugural, isto é, uma repetição da cosmogonia” (ELIADE, 1992, p. 57). $\grave{I} \sin k u^{41}$

Pode-se dizer que a filosofia de vida yorùbá está sustentada no tripé: riqueza (ọlà), filhos (omọdé) e vida longa (aikú). A vida longa é o mais importante, pois possibilita a conquista das outras duas. De fato, a vida é entendida sempre como boa, uma dádiva de Olódùmarè, por isso os yorùbá entendem que a vida é o bem mais 41 Este subtítulo é uma adaptação revisada e atualizada de um artigo que publiquei na Revista Identidade! das Faculdades EST. (SILVEIRA, 2012). precioso que temos e viver bem significa seguir os valores civilizatórios legados pelos antepassados que são rememorados, de tempos em tempos, em rituais específicos.

Foram os antepassados que deixaram para seus descendentes os princípios éticos e morais, assim como o conhecimento da cultura religiosa que serve de cimento na construção das suas vidas. A vida tem que ser vivida na sua plenitude.

A percepção de mundo yorùbá é completamente sensitiva: o tato, o olfato, a visão, a audição e o paladar estão presentes em todos os ritos, seja de nascimentos, casamentos, iniciações ou morte.

A vida é sempre celebrada. Entendo que na visão de mundo ocidental, bom é estar morto, pois a vida é vista como algo difícil, o sofrimento é entendido como inerente à vida e que o melhor lugar para se estar é perto de Deus, ou seja, morto.

A palavra "escatologia" é oriunda do grego "éscatos" ( $\varepsilon \sigma \chi \alpha \tau o \varsigma)$, que significa

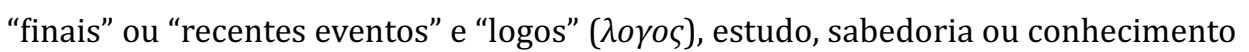
(CAUTHRON, 1984, p.304). Segundo o autor, este estudo se refere à interpretação dos textos sagrados sobre os acontecimentos no final da história do mundo (CAUTHRON, 1984). Neste sentido, a escatologia yorùbá busca responder à questão: para onde vamos ao morrermos?

Para os yorùbá, a existência transcorre simultaneamente em dois planos: no Ayé e no Ọrun. 0 Ayé $e^{42}$ é a Terra, o mundo material, imanente, onde vivem os ara-Ayé, os seres naturais. 0 ọrun é o espaço mítico sobrenatural, imaterial, transcendente, onde vivem os ara-Ộrun, os seres sobrenaturais. Quanto ao ọ̀run, Juana Elbein dos Santos (2002, p. 72) é taxativa ao descrevê-lo:

[...] o espaço ọ̀run compreende simultaneamente todo o do àiyé, terra e céu inclusos, e consequentemente todas as entidades sobrenaturais, quer elas sejam associadas ao ar, à terra ou às águas, e que todas são invocadas e surgem da terra. É assim que os ara-ọ̀run são também chamados irúnmalẹ [...].

É no Ọ̀run que se encontra Olódùmarè, os Òrìsà e os ancestrais. Olódùmarè é o Deus único na percepção de mundo dos yorùbá e os Òrișà são divindades criadas por Ele para serem agentes da manutenção da Criação.

42 Em todas as produções textuais investigadas, a palavra yorùbá para "Terra", no sentido de planeta, é escrita pelos autores como àiyé. Mas durante o curso de fruição no idioma yorùbá promovido pelo Prof. Gideon Babalolá İdòwú, nativo de Lagos, Nigéria, este escrevia Ayé. Ao ser questionado, informou que, assim como ocorreu com a língua portuguesa, a língua yorùbá também sofreu reformas ortográficas. Então, desde 1974, esta é a forma oficial de escrever. 
Cada Òrìsà ganha seus poderes de Olódùmarè. Esses poderes são muito específicos, fazendo com que os Òrìsà se tornem interdependentes no cumprimento de seus papéis no cosmo. Este é o valor civilizatório africano da complementaridade, fazendo com que alguns Òrișà tenham papéis importantes no processo escatológico como é o caso de Ộrúnmilà, Ìkú e Ọya.

Òrúnmilà é a testemunha de Olódùmarè, conforme anunciado anteriormente. Ele estava na criação do mundo e dos seres humanos, por isso é regente do mundoalém e também deste mundo. Por ser testemunha, Òrúnmilà sabe tudo o que deve ser feito quando chegar a morte de cada ser humano, incluindo a data de morte, já que Ele presencia quando os seres humanos a contam a Ėș̀ Oníbodè, o guardião dos portões que separam o Ộrun do Ayé.

Outra importante divindade escatológica é a Morte, pois, segundo José Beniste (2008, p. 191), ela é vista "como um agente criado por Olódùmarè para remover as pessoas cujo tempo na Terra tenha terminado". İkú, a Morte, é uma divindade masculina cuja lógica de existência é dirigida a pessoas velhas, motivo pelo qual a morte de um jovem é vista como uma tragédia. Um itán revela a origem de seu nefasto ofício:

No dia em que a mãe da morte foi espancada no mercado de Ejìgbòmẹkùn a Morte ouviu e gritou alto enfurecida. A Morte fez do elefante a esposa de seu cavalo. Ele fez do búfalo sua corda. Fez do escorpião o seu esporão bem firme pronto para a luta. (BENISTE, 2008, p. 192)

De acordo com José Beniste (2008), este evento fez com que İkú matasse indiscriminadamente, criando grande caos no mundo ${ }^{43}$. Então, Ifá foi consultado e ensinou as pessoas a fazerem oferendas para acalmar a Morte. Assim foi feito e a ordem se estabeleceu novamente. İkú então se dedicou a levar apenas aqueles que já viveram o bastante na Terra. Em outra história sagrada, Ìkú ganha sua missão de Olódùmarè por ter sido o Òrìsà que deu a Òsàlá a lama primordial para fazer os seres humanos:

Quando Olódùmarè ordenou que Òșàlá criasse os seres humanos, pediu para todos os òrị̀à que trouxessem o material que melhor servisse.

43 Talvez por isso, para Abímbọ́lá (1975), İkú também é um ajogun, que são seres sobrenaturais maléficos.
Trouxeram madeira, pedra, água, areia, mas nada resolvia. İkú pediu para que Nàná cedesse o elemento de seus domínios, a lama primordial, para que Òsàáá fizesse os seres humanos. Ela concordou desde que Ele ficasse incumbido de trazer a lama de volta ao final da vida de cada indivíduo. Assim se sucedeu: Òșàlá cria os seres humanos da lama primordial e Ìkú os trata de devolver para Nàná. (BENISTE, 2008, p. 193)

Então quando a pessoa é tocada por İkú, seu corpo biológico perece - é abandonado por Bara tornando-se imóvel - e é restituído à natureza ao ser enterrado. É crucial que o corpo seja enterrado, pois na percepção de mundo dos yorùbá é na decomposição dos corpos que sua força vital se redimensiona, fortalecendo a família e a comunidade. Além disso, o Ėmí permanecerá junto ao corpo por um período de dias, que em África é de nove e no Brasil é de sete, provavelmente devido ao sincretismo com a missa de sétimo dia católica.

De forma alguma o corpo pode ser cremado, pois isto é entendido como a destruição do corpo, o que impede que sua alma, o Ẹmí, seja imortalizada. A cremação é até mesmo aplicada como castigo aos "feiticeiros", aqueles que manipulam as forças cósmicas para prejudicar alguém:

Por sua vez, o castigo que a sociedade africana impõe ao feiticeiro corresponde à concepção de vida e à escala de valores que lhe são próprias. Sendo a vida, sua propagação e conservação o valor máximo, aquele que com toda a força vital entregou-se à destruição desse valor, recebe também a punição máxima, isto é, a eliminação total da vida. Assim, contrariamente a todos os outros homens, o feiticeiro, após a morte, não é enterrado, mas incinerado ou jogado como pasto às hienas. 0 feiticeiro é $o$ único a quem não é permitido sobreviver, sendo excluído da "imortalidade" prometida aos homens. Sua força vital se dissolve com a morte, e ele não pode mais ser chamado à existência por palavra alguma. A sociedade africana reserva, pois, a mais terrível punição metafísica àquele que destruiu a vida e fez mau uso da palavra: a aniquilação total, a única morte verdadeira e definitiva. (REHBEIN, 1985, p. 57)

Esta morte é considerada definitiva, porque para os africanos de modo geral, e mais especificamente para os yorùbá, a morte não é o fim, mas um portal para uma nova vida que continua no Ọ̀run e, posteriormente, será restituída novamente à vida em um novo e infindável ciclo. 
Já vimos, na parte desse trabalho dedicado ao Borí, que o nosso "corpo espiritual" é composto de várias "almas" reunidas. Estas almas, de acordo com Juana Elbein dos Santos (2002), José Beniste (2008), Reginaldo Prandi (2005), Wándé Abímbọ́lá (1975) e William Bascom (1960), terão um destino próprio, cada uma com o perecimento do "corpo biológico". Imediatamente Bará o deixa, e a evidência é a imobilidade do corpo; o Òriṣà pessoal, que define a origem mítica da pessoa, retorna ao Òrișà primordial, do qual é uma parte infinitésima. 0 orí-inú, o princípio de individualidade, perece com ela e a acompanha na morte, juntamente com o seu projeto mítico-social. Esta narrativa está contida no longo itán reproduzido por Reginaldo Prandi (2001, p. 476-481) no livro, Mitologia dos Orixás.Neste itán fica evidente que os Òrị̀à nunca acompanharão seus filhos, seus descendentes míticos, na morte. Apenas o Orí, ou seja, apenas a divindade pessoal representada tanto pela cabeça física quanto pela mítica, o İgbá-Orí, que simbolicamente se apresenta como o ìpọnrí, se finda com a morte. Mas este não é um fim de fato. Nessa percepção de mundo o indivíduo não acumula consciência, como ocorre no hinduísmo, no budismo e no espiritismo. De acordo com William Bascom (1960) e Wándé Abímbọ́lá (1981), o orí-inú é constituído também pelo iyèrántí, a memória individual da vida, de quem o indivíduo foi e o que fez. Ele se juntará ao òjìji, a sombra, ao èémí, a respiração/ espírito, e ao ẹmí, a alma, que abandonam o corpo e vagam unidos pelos lugares que a pessoa conhecia quando viva, como um fantasma, visitando amigos e parentes. Após os ritos escatológicos a alma do indivíduo será levada por Oyya ao ọ̀run Àsàlú, onde será julgado pelo próprio Olódùmarè em um processo chamado de İdájọ.

[...] os mortos são encaminhados a um desses espaços após o fator decisivo do julgamento divino, pois, na realidade, o julgamento ocorre durante todo o tempo de vida da pessoa na Terra. As divindades contrárias ao mal acompanham as pessoas em sua vida diária e dão a sua punição: o juízo final fica a cargo de Olódùmarè, decidindo quais são os bons e quais são os maus, e os encaminham para os respectivos ộrun. 0 julgamento é baseado nos atos praticados na Terra e devidamente registrados no orí inú, que retorna para Olódùmarè. (BENISTE, 2008, p. 201)

Após o julgamento, o "composto de almas" se desfaz: òjiji desaparece; èémí retorna a Olódùmarè, seu gerador; o ẹmí aguardará o retorno ao mundo e ao seio familiar, continuamente, através do àtúnwa (renascimento); o orí-inú se torna apenas iyèrántí que será cultuada como Égún, espírito individual de antepassado familiar, se tiver sido uma pessoa que mereça este reconhecimento pela comunidade se não, fará parte do culto coletivo aos ancestrais como okù-ọrrun. (AWOLALU, 1996; ABÍMBọ́LÁ, 1981)

Aquele que não recebe os rituais prescritos pode se tornar um Ápáráká, espírito perturbador, sombra ou fantasma. 0 mesmo ocorre com aqueles que não alcançaram o tempo de morrer ainda. Para os yorùbá, quando o ẹmí se encontra com Eșù Oníbodè a caminho do Ayé, este lhe pergunta quando regressará ao ọ̀run. Oníbodè não permite que haja regressos antes do tempo que lhe foi dito, por isso òjiji vaga como uma sombra fantasmagórica; e quando é um espírito falante, é porque está acompanhado do èémí, a respiração. "Eles permanecem na terra até que seu dia finalmente chega" (BASCOM, 1960, p. 6).

De acordo com essa cosmopercepção, o regresso ao mundo, ou seja, o àtúnwa, não é exatamente uma reencarnação como aponta José Beniste (2008, p. 203), já que a permanência do iyèrrántí no ộrun indica que o ser individual permanece único e não retorna mais do "além-mar". Por isso, cada criança que nasce em África, ainda que seja reconhecida como o retorno de um antepassado seu, deverá cumprir todos os ritos - sobretudo o Borí - que garantem a sua individuação como um novo ser. 0 que efetivamente retorna é o èmí.

Divindade feminina, Oya está intimamente relacionada com as almas dos mortos - os Égún. Ela carrega um ìrùkéré, um pequeno espanta-moscas feito com rabo de cavalo que serve para controlá-los. É a divindade escatológica por excelência, pois é quem leva as almas dos mortos para um dos nove espaços de ọ̀run (SANTOS, 2002, p. 182-186).

Alguns itán narram seu poder sobre os Égún. Em um deles Oya é esposa de Ògún, o Òrìsà ferreiro. Ela atiça o braseiro que esquenta o metal, fazendo um som melodioso que atraiu um Égún que vinha passando, o dominando. (VERGER, 1997)

Noutro itán, Ode Odulẹke - o grande chefe caçador - encontrou uma órfã Nupe no mercado principal de Kétu, seu reino. A garotinha estrangeira parecia uma cabrita levada. Oduleke resolveu adotá-la dando-lhe o nome de Oya: ligeira, rápida, em língua yorùbá. Passou-se o tempo e o chefe caçador ensinou à filha tudo o que sabia de magia, caçadas e estratégias de guerra, exercitando-a na generosidade e no gosto pela arte. Um dia, İkú levou o grande Ọdẹ, para a tristeza de Ọya, a qual durante 
sete dias e sete noites cantou e dançou em homenagem àquele que amara tanto. Ela reuniu as ferramentas de caça de Odulẹke, cozinhou as iguarias de que mais gostava, entoou os cânticos mais significativos em homenagem ao pai, dançando durante sete noites na companhia de seus colegas de caça, e de todos os amigos, que também dançaram, cantaram e celebraram a memória de um bravo: o grande provedor da aldeia. Durante o àjèjé (vigília), os amigos confraternizaram-se e os desafetos congraçaram-se. Na última noite, os celebrantes reuniram todos os pertences, as comidas e ferramentas de Ode e foram depositar o carrego ${ }^{44}$ no pé de um Iróko, a árvore Òrìsà, nas profundezas da mata. (BENISTE, 2008; PRANDI, 2001)

Olódùmarè, inspirado pela dedicação de Oya, lhe concedeu o título de Rainha dos Espíritos, ficando com a responsabilidade de atravessar a alma do falecido entre os nove espaços do Ọrun. Assim, Ode Oduleke se tornou o primeiro ancestral a ser cultuado, sendo chamado de Ėsá Akèrán. E o ritual criado por Oya foi o primeiro Aròsún, nome dado aos rituais fúnebres no Batuque ${ }^{45}$. No Candomblé de origem Kétu o nome dado é àsệșè, corruptela de àjèjè, e o primeiro a ser homenageado nesta liturgia é Odẹ. Nos rituais de passagem, nas tradições de matriz africana, costumamse entoar cantigas em homenagem aos ancestrais de todas as Nações.

o Aròsún é uma cerimônia na qual os iniciados dançam, cantam, comem e bebem. A liturgia é pública e os visitantes são convidados para a partilha das iguarias. 0 traje branco é obrigatório. A cor branca é utilizada nas celebrações de nascimento e transformação, sendo necessária nos ritos de passagem de todas as Nações.

Os rituais tem início no dia de falecimento do iniciado. 0 corpo é velado no terreiro. As pessoas dançam e cantam em homenagem ao falecido; balançam seus braços para frente e para trás indicando que todos estão passando vivos por aquele momento. Depois sai o cortejo fúnebre com familiares pegando o caixão e balançando, para frente e para trás, em um movimento que simboliza o limiar do pertencimento tanto a este quanto ao outro mundo.

No sexto dia, de acordo com os fundamentos da tradição Ijẹșà do Batuque, são feitos os sacrifícios rituais, entoam-se cânticos, faz-se oferendas e come-se o "arroz com

44 Um saco feito de linhagem ou cesto de palha ou vime com tudo o que pertencia ao falecido.

45 Do yorùbá: ara (corpo) e òsùn (sono). Aròsún pode significar o "corpo que dorme", pois para os yorùbá "o sono é primo da morte" (PIERRE, 1998). Os bantus, que deram origem aos chamados candombles de Angola, celebram o Mukondo e os jeje, o sihum ou azeri, tambem chamado de "tambor de choro" do morto. galinha”, prato proibido nos outros dias, mas propiciatório nesses rituais. Ao sétimo dia são entoados os cânticos sagrados novamente. Prepara-se um banquete em que todos se refestelam. À ponta da mesa ninguém fica, pois é o lugar do falecido que, acreditase, estar ali. Após o banquete, dança-se em círculo no sentido horário, o sentido da vida, e alguns Òrị̀à se manifestam em seus iniciados. Neste rito específico os Òrị̀à se manifestam silenciosamente, exceto Oya que faz ecoar sua gargalhada visceral, avisando aos quatro cantos da Terra que ela está presente. Oya veio buscar a alma do morto.

No final da liturgia, todos os implementos que pertenciam ao falecido, assim como as comidas de que gostava e as oferendas são reunidas num carrego que será depositado no mato. 0 mato é um espaço sagrado que também está relacionado com os ancestrais, como vimos no itán mais acima.

Oya carrega a alma do morto para o ọ̀run Àsàlú, onde Olódùmarè julgará seus atos e seu caráter. Ali Olódùmarè dará seu veredito final absolvendo ou condenando a pessoa. Caso a pessoa seja absolvida, irá para um dos bons espaços: Ò̀run Rere, o bom lugar para aqueles que foram bons durante a vida; Ộrun Àlàáfíà, o local de paz e tranquilidade; Ộrun Funfun, espaço do branco e da pureza; ou ộrun Bàbá Eni onde se encontrará com seus ancestrais. Mas se a pessoa for condenada, seu destino poderá ser o Ộrun Aféfé, local onde os espíritos permanecem até tudo ser corrigido e onde ficarão até renascerem; Òrun Àpàádì, espaço dos "cacos", do lixo celestial, das coisas quebradas e impossíveis de serem reparadas ou restituídas à vida terrestre através do renascimento; ou Ộrun Burúkú, o mal espaço, quente como pimenta, destinado às pessoas más. No Ộrun Àkàsò, os espíritos aguardam o regresso ao mundo através do renascimento. (SANTOS, 2002; BENISTE, 2008)

Ninguém traz nada da vida anterior para esta, portanto os conceitos espíritas de carma e a "lei da causa e efeito" que implicam os reecarnados não se aplicam à cosmopercepção yorùbá. Estar vivo é a motivação para os yorùbá. A morte é enfadonha, por isso nós, que vivenciamos a tradição yorùbá, nos apressamos para retornar à vida, pois bom é estar vivo.

A ideia de poder ser mandado para um dos "maus espaços" de ọ̀run é perturbadora, por isso os seres humanos devem se portar de maneira exemplar no Ayé. É o comportamento humano que determinará isso. Assim é apontado que, pela ética yorùbá, os valores devem ser seguidos para garantir uma vida plena e uma pósvida promissora. 
Em minhas reflexões, cheguei a três valores que me parecem ser importantes: Orí rere, İwàpẹlè e e ebọ. Orí rere é a prática das coisas boas: as boas palavras, ouvidos generosos, bons pensamentos, boas ações. Ìwàpẹlẹ é o bom caráter, nunca mentir, nunca enganar; e o ẹbọ são as oferendas que devem ser feitas após a consulta a Ifá. A ideia amplamente divulgada de que tudo o que nos ocorre é por merecimento, sejam coisas boas ou ruins, não se aplica gratuitamente na percepção africana de mundo.

A noção de mérito, de prêmio/castigo é judaico-cristã-islâmica e faz parte das tradições religiosas ditas proféticas. Em algumas tradições africanas não há uma noção de castigo como a aplicada no Ocidente, mas sim de resgate do indivíduo, como diz o poema de Tolba Phanem, amplamente divulgado (A CANÇÃO, [S.d.]). É possível ver ecos disso entre vários povos africanos. A noção do Ubuntu se reflete na preocupação tanto do indivíduo com o coletivo, quanto o contrário, pois o indivíduo pode comprometer todo o coletivo. Os valores africanos giram sempre em torno da comunidade, de forma que méritos pessoais não cabem, exceto se atingem diretamente a própria comunidade. O esforço pessoal através do trabalho e da dedicação está embutido na ontologia africana.

Contudo, os Òrìsà atendem os nossos pedidos não por merecermos, mas por termos feito o e bo propiciatório. As histórias sagradas falam sobre preferências dos òrișà e como se conquista algo a partir da observação dessas preferências. Um ẹbo não é magia, mas uma oferenda à divindade esperando uma bênção. Esta bênção é certa se estiver tudo perfeito.

o único ẹo recusado pelas divindades é aquele mal feito ou realizado por pessoa mentirosa. Isso fica nítido no seguinte trecho de um oríki para Șàngó: (SÀLÁMÌ, 1990. p. 85-109).

\section{Abá wọn jà má jébi Òtá òpùró olọ́lo tí nfí enu èke lọlè} Bàbá nlá, a kò má gbe ebo èké rù

Aquele que nunca briga injustamente Inimigo dos mentirosos

Aquele que esfrega a boca do mentiroso no chão Grande Pai, que faz com que o ẹbo do mentiroso não tenha efeito.
Em outro oríki (SÀLÁMì; RIBEIRO, 2011, p. 354), dedicado a Èșù, é revelado que este Òrìșà não tolera o mentiroso, por isso não aceita e nem leva suas oferendas para os outros òrị̀̀ă: "A kò má gbẹbo èké rú. [Ėșu] se recusa a levar o ẹbọ do mentiroso."

Isto promove na pessoa a ideia de que deve se portar bem em sociedade, constrói no ser humano um sentimento de cidadania, civilização, respeito ao próximo, ao coletivo, a toda humanidade, enfim. Não é à toa que a expressão em língua nativa gbobo ohun ti a bà se ni Ayé l'a o kunlẹ rò ni ộrun significa: "todas as coisas que fazemos na Terra damos conta de joelhos no Ọrun".

Considerações finais

Evidenciamos aqui, mais uma vez, a sabedoria africana. Os ritos presentes nas tradições de matriz africana são extremamente importantes para os vivenciadores, pois é a materialidade, a vivência, a experiência dos ritos que garante para o povo de terreiro a certeza de que sua relação com o sagrado está bem alocada.

Em complemento à importante obra escrita por Jostein Gaarder, Victor Hellern e Henry Notaker (2000), O livro das religiões, o sociólogo e professor paulista Antônio Flávio Pierucci (2000, p. 318) compara as tradições de matriz africana ao cristianismo e afirma que estas não são religiões éticas como aquela o é, mas sim mágicas, e como tal, busca apenas a manipulação das forças para garantir benesses próprias.

Posso dizer que o referido professor está muito equivocado no que concerne à inexistência da ética, mas que está certo ao entender a importância dos ritos para essas tradições. Conforme evidenciado neste estudo que, obviamente, não se encerra com essas linhas.

É importante estudarmos as complexidades dos Orò nas diferentes tradições de matriz africana como elemento crucial dos Ogbọ́n Mẹ́fà, constituindo o corpus oral epistêmico dessas tradições. Entendermos os propósitos do Borí, do Ọsẹ́ e do Ìsinkú é importante na construção de significados não apenas religiosos, mas como um sentido dinâmico e constitutivo da cosmopercepção das tradições de matriz africana como o Batuque e o Candomblé.

A afroteologia, ou seja, a teologia das tradições de matriz africana, se torna um campo fundamental para a compreensão da matriz civilizatória africana no mundo ao propor uma sistematização do conhecimento ancestrálico africano 
herdado pelos Bàbálórìșà e Ìyálórìșà, autoridades civilizatórias - como diz o Prof. Jayro - que emergem como líderes na resistência e na defesa dessas tradições.

\section{Referências}

A CANÇão dos homens. Música: Ladysmith Black Mambazo, Joseph Shabalala. 3 min., son., color Legendado. [S. d.]. Disponível em: https://youtu.be/5D9ZOaOArj0. Acesso em: 12 nov. 2020

ABÍMBớLÁ, Wándé. İwàpèlè: 0 conceito de bom caráter no corpo literário de Ifá. Tradução de Rodrigo Ifáyodé Sinoti para uso didático. In: SEMINÁRIO SOBRE TRADIÇÃO ORAL IORUBA: POESIA, MÚSICA, DANÇA E DRAMA. 1975, Nigéria. Ile Ifé. Anais [...]. Ile Ifé: Universidade de Ile Ifé, 1975. p. 1-15. Disponível em: https://bitly/3593ffq..

ABÍMBớLÁ, Wándé. A concepção iorubá da personalidade humana. Tradução de Luiz L. Marins para uso didático. In: COLÓQUIO INTERNACIONAL PARA A NOÇÃO DE PESSOA NA ÁFRICA NEGRA, 1971 Paris. Anais [...]. Paris: Centre National de La Recherche Scientifique, 1981. p. 1-22. Disponível em: https://filosofia-africana.weebly.com/.

AWOLALU, J. Omosade. Yorùbá beliefs and sacrificial rites. New York: Athelia Henrietta Press, 1996.

BASCOM, William. Concepção iorubá da alma. Tradução de Aulo Barretti Filho e Luiz L. Marins para uso didático. In: CONGRESSO INTERNACIONAL DE CIÊNCIAS ANTROPOLÓGICAS E ETNOLÓGICAS, 50 1960. Filadélfia. Anais [...]. Filadélfia: Universidade da Pensilvânia. 1960. p. 1-19. Disponível em https://bit.ly/2MkxMOS.

BENISTE, José. Ò̀run-Àiyé, o encontro de dois mundos: o sistema de relacionamento nagô-yorubá entre o céu e a Terra. 6. ed. Rio de Janeiro: Bertrand Brasil, 2008.

CAUTHRON, Hal A. Escatologia. In: TAYLOR, Richard S.; GRIDER, J. Kenneth; TAYLOR, Willard H. (ed.). Dicionário Beacon Teológico. Lanexa, Kansas: Casa Nazarena de Publicações, 1984.

CINTRA, Raimundo. Candomblé e umbanda: o desafio brasileiro. São Paulo: Paulinas, 1985.

ELIADE, Mircea. O mito do eterno retorno. São Paulo: Mercuryo, 1992.

JAY, Nancy. Com toda a tua descendência para sempre: sacrifício, religião e paternidade. São Paulo: Paulus, 1997.

OYĚWÙMÍ, Oyèrónkẹ́. The Invention of Women: making an african sense of western gender discourses. Minneapolis: University Of Minnesota Press, 1997.

PIERRE Fatumbi Verger: mensageiro entre dois mundos. Direção de Lula Buarque. Produção de Pedro Buarque de Hollanda, Flora Gil, Leonardo Monteiro de Barros. Roteiro: Marcos Bernstein. Música: Naná Vasconcelos. Brasil: Conspiração Filmes. 1998, 1 DVD (86 min.), NTSC, son., color. Legendado. Narrado por Gilberto Gil. Disponível em: <nttps://youtu.be/tlbornZeH_p4>. Acesso em: 18 jun. 2020

PIERUCCI, A. F. Apêndice: as religiões no Brasil. In: GAARDER, J.; HELLERN, V.; NOTAKER, H. O livro das religiões. Trad. Isa Mara Lando. São Paulo: Companhia das Letras, 2000.

PRANDI, Reginaldo. Mitologia dos orixás. São Paulo: Companhia das letras, 2001.

PRANDI, Reginaldo. Segredos guardados: orixás na alma brasileira. São Paulo: Companhia das Letras, 2005.

REHBEIN, Franziska C. Candomblé e salvação: a salvação na religião nagô à luz da teologia cristã. São Paulo: Loyola, 1985.
SÀLÁMÌ, Síkírù. Mitologia dos orixás africanos. São Paulo: Oduduwa, 1990

SÀLÁMÌ, Ś́kírù; RIBEIRO, Ronilda Iyakemi. Exu e a ordem do universo. São Paulo: Oduduwa, 2011.

SANTOS, Juana Elbein dos. Os nàgó e a morte: pàdé, àșẹ̀sẹ̀ e o culto égún na Bahia. 11. ed. Petrópolis: Vozes, 2002.

SILVEIRA, Hendrix. Gbobo ohun ti a bà se ni ayé l'a o kunlè̀ rò ni Òrun: processo escatológico no Batuque do Rio Grande do Sul. Identidade!, v. 17, n. 02, 2012. p. 247-258. Disponível em: https://goo.gl/ C9er6C. Acesso em: 15 mar. 2020.

SILVEIRA, Hendrix. Não somos filhos sem pais: história e teologia do Batuque do Rio Grande do Sul. São Paulo, SP: Arole Cultural, 2020

VERGER, Pierre. Orixás: deuses iorubás na África e Novo Mundo. 5. ed. Salvador: Corrupio, 1997. 


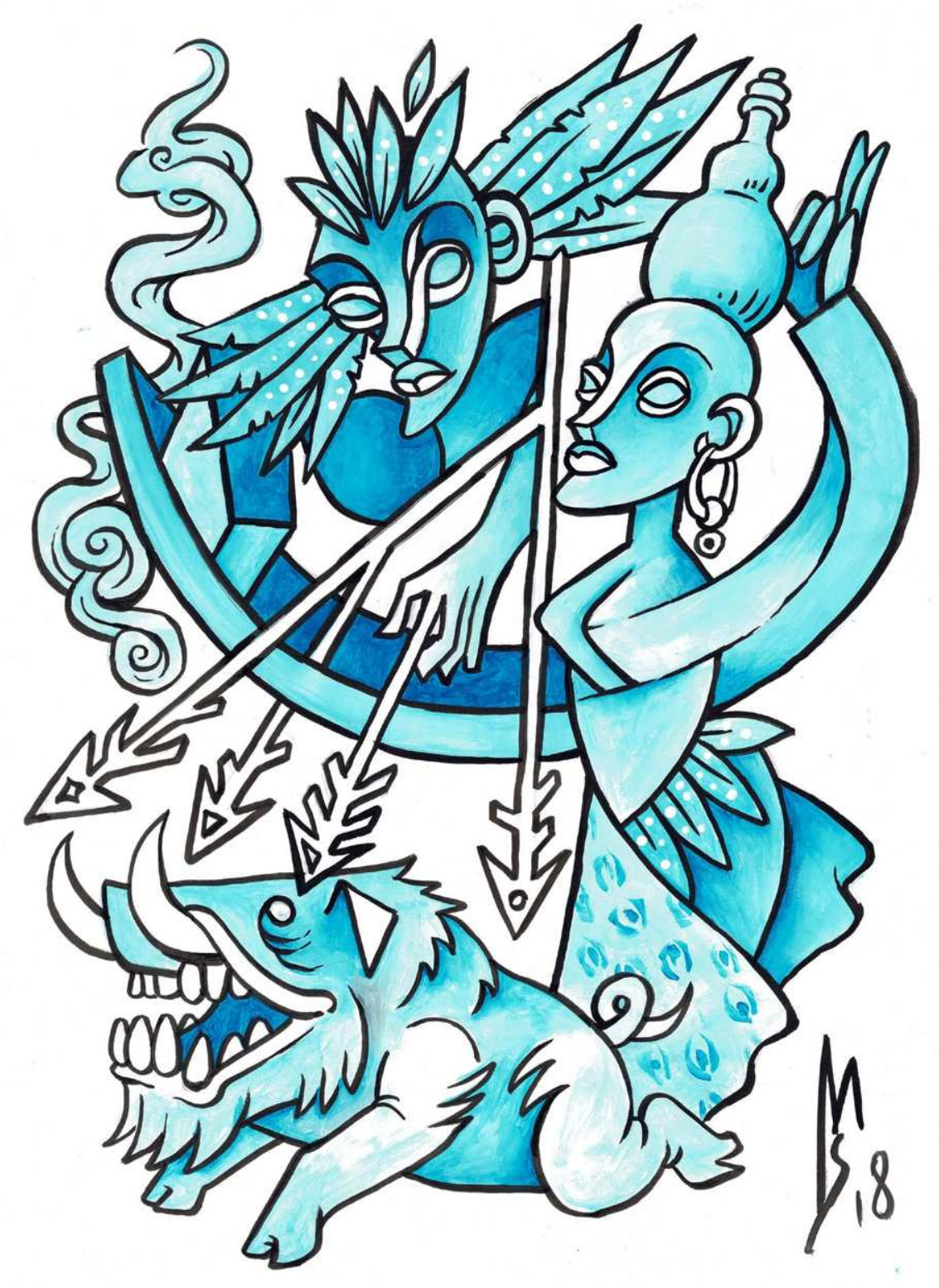

\section{Ode e Otin ${ }^{46}$}

Princípio masculino.

Princípio feminino.

Cuidam da alimentação da comunidade

para que não haja fome.

Cuidam do equilíbrio não predatório das florestas,

da mata virgem, da caça.

Ele é caçador! Ela é caçadora!

Aqueles que representam a abundância de alimento resultante da caça. No mato, são sabedores do valor curativo das folhas.

Encontram os melhores territórios para uma nova roça,

para a ampliação da comunidade.

Ode e Ọtìn - astúcia, inteligência, discernimento e cautela são atributos.

A flecha é única,

jamais erram a presa.

46 Oríkì (louvação) para Ọde e ọ̀tìn, construído a partir das obras: "Agadá: dinâmica da civilização afride Juana Elbein dos Santos (2012); e “Dicionário yorubá-português”, de José Beniste (2011). 


\section{REFLEXÕES SOBRE A FALSA UNIVERSALIDADE DA TEOLOGIA JUDAICO-CRISTÃ: EPISTEMICÍDIO E A CONSTRUÇÃO DO "OUTRO"47}

Valéria Fernandes de Carvalho

Durante séculos temos carregado o peso dos crimes e dos erros do eurocentrismo 'científico', os seus dogmas impostos em nossa carne como marcas ígneas da verdade definitiva. Agora devolvemos ao obstinado segmento 'branco' da sociedade brasileira, as suas mentiras, a sua ideologia de supremacismo europeu, a lavagem cerebral que pretendia tirar a nossa humanidade, a nossa identidade, a nossa dignidade, a nossa liberdade. Proclamando a falência da colonização mental eurocentrista, celebramos o advento da libertação quilombista (NASCIMENTO, 2019, p. 288).

Introdução

O presente artigo apresenta algumas reflexões acerca da farsa construída pela teologia judaico-cristã, ao se autodefinir como teologia universal, como uma das estratégias fundamentais para o projeto da colonialidade ${ }^{48}$.

A partir da compreensão e das problematizações apresentadas por Eduardo Gross (2008) no que diz respeito à concepção de teologia, e da concepção de epistemicídio ${ }^{49}$ de Aparecida Sueli Carneiro (2005), discorro sobre como a pretensa 47 “Os 'Outros', neste caso, são aqueles vistos pela identidade do Ser universal, autoinvisilizante, branca, cis, heteropartriarcal como os diferentes dos humanos normativos" (AKOTIRENE, 2018, p.114). 48 "A colonialidade é um dos elementos constitutivos e específicos do padrão mundial do poder capitalista. Sustenta-se na imposição de uma classificação racial/étnica da população do mundo como pedra angular do referido padrão de poder e opera em cada um dos planos, meios e dimensões, materiais e Arvos, da existencia social quotidiana e da escala societal (QUI)ANO, 200, p.73).

(2005) recida Sueli Carneio (2005). Segundo esta autora "[...] o epistemicidio é, para aleñ da anulaçăo e desqualificação do conhecimen-

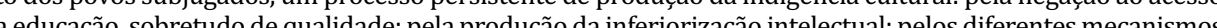
de deslegitimaç̃̃o do negro como portador e produtor de conhecimento e de rebaixamento da capacidade cognitiva pela carencia material e/ou pelo comprometimento da autoestima pelos processos de discimina-

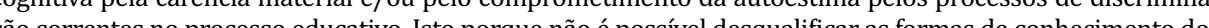
povos dominados sem desqualificá-los também individual e coletivamente, como sujeitos cognoscentes. E ao fazê-lo, destitui-lhe a razão, a condição para alcançar o conhecimento "legítimo" ou legitimado. Por isso o epistemicídio fere de morte a racionlidade do subjugado ou a sequestra mutila a capacidade de aprender etc. É uma forma de sequestro a racinanalidade do subjugado ou a sequestra, mutila a capacidade de aprender etc. lação cultural que em outros casos lhe é imposta" (CARNEIRO, 2005, p. 97). universalidade da teologia cristã pode ser caracterizada como epistemicídio, na medida em que ao restringir a concepção de teologia, essa concepção impede não somente que os conhecimentos e as epistemologias presentes na teologia de matriz africana sejam reconhecidos e legitimados, como também, nega esta perspectiva de racionalidade.

As reflexões que apresento tiveram origem no meu processo de seleção para o curso de "Introdução ao Estudo da Filosofia e Teologia Africana, Afrocentrada da Tradição de Matriz Africana para Povo de Terreiro", organizado e desenvolvido pela Escola Aldeia Ubuntu Vale do Akòko, e coordenado pelo professor Jayro Pereira de Jesus.

A partir das leituras dos textos de Eduardo Gross (2008) e Eliza Larkin Nascimento (2008), o coordenador do referido curso solicitou que dissertássemos sobre a seguinte questão: “Teologia não é uma teleologia judaico-cristã e/ou católica e muito menos uma concessão por conta do dado da 'Revelação', fenômeno particular exclusivo e tão somente do Cristianismo" (JESUS, 2020) ${ }^{50}$.

No primeiro momento do artigo faço um diálogo direto com o texto de Eduardo Gross (2008), com intuito de apresentar minhas compreensões acerca do mesmo e, a partir disso, apresento, na segunda seção, minhas considerações acerca da reflexão destacada acima

Teologia ou teologias?

Escolhi o questionamento "Teologia ou teologias?", colocado por Eduardo Gross (2008), para título da primeira seção do meu artigo, porque entendi que é nesse momento do texto que o autor nos coloca a necessidade e importância de uma crítica e de uma desconstrução que considero fundamentais para as reflexões aqui propostas, quais sejam:

[...] a crítica a qualquer forma de pretensão exclusivista de tradição religiosa particular se arrogar um lugar privilegiado enquanto discurso teológico. Particularmente no âmbito da teologia, isso significa a necessidade de uma desidentificação entre teologia e teologia cristã [...] (GROSS, 2008, p. 331).

0 autor abre, então, a possibilidade de entendimento sobre sua concepção acerca do que é teologia; sobre o que ele considera como mal-entendido em relação

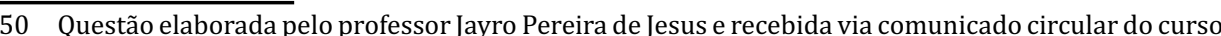


ao termo teologia, sobre as raízes do mesmo no contexto brasileiro, assim como sobre suas consequências.

Eduardo Gross (2008) expõe que o mal-entendido, no que se refere ao significado do termo, advém das influências do positivismo e do domínio da teologia cristã no âmbito público, na medida em que essas perspectivas separaram o que é do âmbito científico e o que é do âmbito "teológico", definindo e determinando, assim, quem teria autoridade para investigar os temas de cada um dessas áreas de influência.

Por conta disso, o autor avalia que, durante muito tempo, os estudos acerca da religião ficaram restritos ao âmbito das instituições de formação religiosa, impedindo ou dificultando, desta forma, a compreensão do lugar da teologia nos estudos da religião e da importância da reflexão sobre a relação entre teologia e as demais disciplinas acadêmicas que tratam da religião.

[...] um problema básico e de grandes consequências é a apressada identificação entre teologia e teologia cristã (às vezes ainda católico-romana) corrente no nosso contexto. Esta identificação convenientemente esquece que o termo teologia é anterior ao cristianismo (p. 325)

Com intuito de desconstruir esse problema básico, e a fábula criada pela teologia cristã, Eduardo Gross (2008) apresenta perspectivas de algumas das diversas compreensões acerca do que é teologia - entre elas: de Platão, de Aristóteles, dos estoicos e do cristianismo; assim como, das mudanças que ocorrem com o advento da modernidade. Ao longo desse momento de seu percurso expositivo, Eduardo Gross (2008) nos oferece reflexões fundamentais para os objetivos que ele enuncia como principais em seu artigo.

No entanto, dado o foco do presente artigo, me aterei, neste momento, ao que o autor apresenta como empreendimento teórico audaz dos primeiros teólogos cristãos propriamente ditos, qual seja: a entrada da mensagem religiosa no âmbito filosófico, realizada pelos teóricos do cristianismo. Fato que ocorreu no momento histórico no qual a teologia era tida como ciência, possibilitando que a teologia cristã - com a elevação do cristianismo à religião oficial - passasse a ser considerada ciência imperial. Diante disto:
Outros mitos e símbolos foram vistos como não-teologia, como não ciência e, mais ainda, como erros a serem não só combatidos discursivamente mas até esmagados pela força. Assim teologia, que era e continuou a ser teologia cristã, particular, se tornou a ciência metafísica (GROSS, 2008, p. 327).

A pretensa universalidade da teologia cristã, além de restringir a concepção de teologia, impede que teologias de outras tradições sejam reconhecidas e legitimadas. 0 que me leva a refletir sobre as relações de poder e de dominação e, consequentemente, sobre a desumanização produzida por essa identificação imediata entre teologia e teologia cristã.

A crítica aos efeitos repressores da referida identificação, com o advento da modernidade, levou a religião a ser considerada como manifestação da irracionalidade e, por consequência, levou também a teologia a perder seu estatuto de verdade no meio acadêmico. Estabelece-se tanto uma contraposição entre Teologia e Ciência, quanto o desafio "de a teologia se colocar em diálogo com as demais disciplinas que estudam a religião" (GROSS, 2008, p. 327-328)

Como superar esse desafio? A exposição e as propostas de Eduardo Gross (2008) para superarmos esse desafio evidenciam sua concepção de teologia e sua afirmação da existência de teologias, e não apenas de uma teologia universal.

$\mathrm{O}$ autor propõe concebermos a teologia enquanto discurso simbólico, o que significaria, entre outras coisas, renunciar a uma reivindicação de que seus conteúdos correspondam a uma verdade objetiva. Nesse sentido, o mesmo afirma que caberia à teologia: a) se entender explicitamente como um discurso sobre mitos, ritos e símbolos - ocupando-se com a formulação conceitual rigorosa deste discurso; b) examinar as tradições teológicas passadas, resgatando elementos simbólicos representativos e enriquecedores das mais variadas religiões, assim como; c) valorizar as formas não conceituais de representação do saber enquanto modelos teológicos, isto é, a aproximação entre teologia e mitologia e, desta forma, a descoberta de conteúdos racionais em narrativas míticas (GROSS, 2008).

Essa concepção do autor me leva a refletir sobre a relação entre teologiafilosofia-ontologia, na medida em que a teologia, ao formular os conteúdos racionais das narrativas míticas, pode contribuir para nos fazer compreender os elementos filosóficos imersos nos mitos, nos ritos e nos símbolos das diversas tradições. E 
para entender como essa compreensão pode nos informar sobre as formas de ser de pensar, de agir, de sentir dos diversos povos, ou seja, a constituição ontológica, ética e epistemológica do ser no mundo. Em outras palavras: entender como os seres humanos se constituem e se concebem.

A proposição do referido autor para refletirmos sobre o lugar da teologia nos estudos da religião e sobre a importância da relação entre teologia e as demais disciplinas acadêmicas que tratam da religião, diante de sua redefinição da teologia proposta e exposta ao longo de seu artigo nos permite: a) entender como as interpretações e formulações conceituais dos aspectos racionais - presentes nos mitos, nas narrativas e nos símbolos das religiões/tradições - poderiam contribuir para enriquecer, aprofundar e diversificar as epistemologias das diversas disciplinas acadêmicas, assim como; b) ampliar o conhecimento e sua diversidade em relação ao mundo, à sociedade e às diversas dimensões acerca do conhecimento do ser humano (físico, epistemológico, biológico, epistêmico, estético, artístico, relação com a natureza, etc.), e ainda; c) compreender como a contribuição das teologias em diálogo com os diversos campos acadêmicos poderia ampliar nosso entendimento acerca de outras possibilidades de existir que não a moderno-ocidental - responsável pelos maiores crimes, violências e devastações já produzidas na história da Humanidade.

A partir dessas compreensões apresentarei, na próxima seção, algumas reflexões acerca das implicações da farsa criada pela teologia cristã, no que diz respeito à manutenção do projeto da colonialidade.

O que fizeram de nós? A colonialidade do poder, do ser e do saber

A segunda seção deste artigo é inspirada nos questionamentos do professor Jayro Pereira de Jesus, nos encontros preparatórios para o início de nosso curso, sobre: “O que éramos?”; “O que fomos?”; “O que fizeram de nós?”; e “O que poderemos voltar a ser? Voltar a ser o que nos impossibilitaram de ser".

O colonialismo moderno representa o momento da formação dos EstadosNação da Europa e da origem da formação do sistema-mundo capitalista, via extração de terras e recursos naturais - através da escravização dos povos africanos e indígenas. Denominado de Modernidade, esse tempo histórico é o período das maiores devastações, massacres, violências, extermínios e crimes cometidos contra a maioria significativa da humanidade, e engendra em si um projeto de colonialidade, no qual o discurso acerca da "descoberta" e da invenção do "outro" são estruturantes para sua consolidação e legitimação (BERNADINO-COSTA; GROSFOGUEL; MALDONADO-TORRES, 2019; MBEMBE, 2018).

Nelson Maldonado-Torres (2019) faz uma importante distinção entre colonialismo, colonialismo moderno e colonialidade, que nos ajuda a compreender a relação intrínseca entre modernidade-colonialidade, e entender que sem colonialismo não existiria modernidade. Segundo ele:

Colonialismo pode ser compreendido como a formação histórica dos territórios coloniais; o colonialismo moderno pode ser entendido como os modos específicos pelos quais os impérios ocidentais colonizaram a maior parte do mundo desde a 'descoberta'; e colonialidade pode ser compreendida como uma lógica global de desumanização que é capaz de existir até mesmo na ausência de colônias formais (MALDONADO-TORRES, 2019, p. 35-36)

Chamo atenção para chave de definição, estabelecida pelo autor, ao distinguir colonialismo e colonialismo moderno, qual seja: modo específico de colonizar que se institui desde a "descoberta" pelos impérios do Ocidente. Ou seja, a "descoberta" de terras, a "descoberta" de recursos e a "descoberta" de seres humanos.

Considero a referida "descoberta" uma fábula, e imagino que esta fábula, a fábula dos "descobridores", hipoteticamente os levou a pensar da seguinte maneira, diante dos "descobertos": "Se eu te descobri, é porque você não existia antes. Então, eu te invento. Então, eu é que tenho a autoridade de anunciar para a civilização quem você é. Eu direi quem você é!”.

E como foi que os "descobridores" revelaram sua "descoberta" para o mundo? Através de uma invenção: a invenção do "outro". Através de seu "espelho", de sua "imagem", de sua identidade, de sua forma de ser, pensar, agir e sentir. E todos aqueles que não se enquadravam nessa perspectiva foram excluídos do que os "descobridores" consideravam como seres humanos, foram denominados de "outro" (DUSSEL, 1993; MBEMBE, 2018).

Logo, nessa lógica, o "outro" foi classificado com uma coisa, um objeto. Algo que para aquele que definiu quem é o "outro" - a partir de seu ideal de ser humano 
- se sentiu no direito de dispor/usar como quisesse: inclusive escravizar, violentar e explorar a força de trabalho do "outro" (MBEMBE, 2018).

Eric Williams (2012, p.101), analisando a relação intrínseca entre o capitalismo e escravismo, afirma:

Não existe um tijolo na cidade que não tenha sido cimentado com o sangue de um escravo. Mansões suntuosas, padrões de vida luxuosos, criadagens de libré foram frutos da riqueza construída com os gemidos e sofrimentos dos escravos comprados e vendidos pelos mercadores de Bristol.

Desta forma, a modernidade engendra em si uma lógica colonial que não se restringe à dimensão econômica (expropriação de terras e recursos), na medida em que essa dimensão da lógica colonial só pôde se consolidar através da lógica global de desumanização.

Achille Mbembe (2018) nos mostra como o pensamento europeu tendeu a abordar a identidade a partir de seu próprio espelho. Como se consolidou odiando, manejando o terror, praticando o altericídio, ou seja: inventando o "outro" não como semelhante de si mesmo, mas como objeto propriamente ameaçador, que no limite da impossibilidade de controlá-lo, poderia ser exterminado (MBEMBE, 2018, p 27). A invenção deste "outro" se deu através do que o referido autor denomina de "princípio de raça":

[...] por princípio de raça se deve entender, aliás, uma forma espectral da divisão e da diferença humana, suscetível de ser mobilizada para fins de estigmatização, de exclusão e de segregação, por meio das quais se busca isolar, eliminar e até mesmo destruir fisicamente determinado grupo (MBEMBE, 2018, p.106).

Interessante observar, também, que através da invenção do "outro" a partir do seu "eu", ou seja, de sua identidade e de sua significação, o colonizador, não só inventou o "outro", como inventou a si mesmo. Ou seja, ao definir e dizer quem é o "outro", o colonizador também anuncia, define e afirma quem ele é. Há aqui um evidente processo de "extermínio" da humanidade do "outro" e o processo de afirmação do ideal de ser humano pautado pelo "eu" colonizador (DUSSEL, 1993).

Nesse sentido, Enrique Dussel (1993, p. 8) afirma que a Modernidade:
[...] 'nasceu' quando a Europa pôde se confrontar com o seu 'Outro' e controlá-lo, vencê-lo, violentá-lo: quando pôde se definir como um 'ego' descobridor, conquistador, colonizador da Alteridade constitutiva da própria Modernidade. De qualquer maneira, esse 'Outro' não foi 'descoberto' como Outro, mas foi 'en-coberto' como o 'si-mesmo' que a Europa já era desde sempre. De maneira que 1492 será o momento do 'nascimento' da Modernidade como conceito, o momento concreto da 'origem' de um 'mito' de violência sacrifical muito particular, e ao mesmo tempo, um processo de 'en-cobrimento' do não-europeu.

Dessa forma, nesse processo a Europa se inventa como um ideal, um padrão de civilização, através de dicotomias e maniqueísmos que postulam os demais povos como selvagens ou primitivos.

O projeto da colonialidade só conseguiu se consolidar porque significou uma totalidade: articulando, atuando e se consolidando simultaneamente, através da colonialidade do poder, do saber e do ser. De acordo com Maldonado-Torres (2019, p. 42, grifos meus):

As visões de mundo não podem ser sustentadas apenas pela virtuosidade do poder. Várias formas de acordo e consentimento precisam ser partes delas. Ideias sobre o sentido dos conceitos e a qualidade da experiência vivida (ser), sobre o que constitui o conhecimento ou pontos de vistas válidos (conhecimento) e sobre o que representa a ordem econômica e política são áreas básicas que ajudam a definir como as coisas são concebidas e aceitas em uma dada visão de mundo.

Por isso, considero que o colonialismo moderno engendra em si um projeto de colonialidade: projeto porque me informa sobre uma dinâmica civilizatória que nos (povo negro) desumanizou e desumaniza em todas as dimensões (ética, epistemológica, ontológica) (BERNADINO- COSTA; GROSFOGUEL; MALDONADO-TORRES, 2019).

Eliza Larkin Nascimento (2008, p. 55), nos mostra como "ao longo dos séculos, a ciência ocidental construiu uma série de teses que supostamente comprovaram que os africanos eram criaturas incapazes de criar civilizações".

Tudo que se referia a nossa forma de ser, pensar, agir e sentir foi deslegitimado enquanto conhecimento, foi silenciado, foi criminalizado, foi invisibilizado, foi roubado... 
A negação do passado científico e tecnológico dos povos africanos e a exacerbação do seu 'caráter' lúdico foi uma das principais façanhas do eurocentrismo e que ainda hoje abala fortemente a autoestima da população africana e da diáspora, pois os 'métodos', 'conceitos' e muitos cientistas europeus deram a impressão ao restante do mundo, de que as populações africanas não tiveram uma contribuição relevante para a construção do conhecimento universal (CUNHA, 2006).

Desse modo, no que se refere à lógica do projeto da colonialidade, em relação ao que entendi da concepção de teologia de Eduardo Gross (2008), estabeleço um diálogo com a perspectiva de Patrícia Hill Collins (2019), no que diz respeito à difusão, à origem e à validação do conhecimento. Para esta autora, a origem, validação e difusão do conhecimento revelam a afinidade com o poder que os criou, “[...] homens brancos da elite controlam a validação do conhecimento ocidental, logo seus interesses permeiam temas, paradigmas e epistemologias [...]" (COLLINS, 2019, p. 401).

Portanto, ao mesmo tempo em que a perspectiva eurocêntrica promove o processo de legitimação e reconhecimento da produção de seu conhecimento, deslegitima, promove o apagamento e desqualifica processos de produção de conhecimentos baseados nas narrativas, experiências, paradigmas e metodologias das populações negras e indígenas.

Nessa perspectiva, entendo que a teologia cristã ao se identificar como teologia única/universal, tenta deslegitimar as formulações racionalizantes presentes nas demais religiões/tradições e, desta forma silencia, apaga, violenta e tenta exterminar a compreensão da ontologia, da ética e da epistemologia presentes nas tradições de matriz africana. Nega assim, nossa capacidade de SER, naturalizando e legitimando as violências sobre nossos corpos e sobre todas as nossas dimensões de SER.

0 que remeto ao que o professor Jayro Pereira de Jesus define como desontologização $0^{51}$, que teve entre suas estratégias: a) aquelas pautadas na dualidade e no maniqueísmo ocidental: que promoveram a demonização e a criminalização de tradições de matriz africana e; b) outras que se desenvolveram através do apagão e do arrastão ideológico ${ }^{52}$.

51 Antes mesmo da deportação dos africanos para as Américas, o colonialismo usou essa estratégia do esvaziamento dos elementos ontológicos para subalternizar os africanos". (LOPES, 2020, p. 287). Entre-

52 Aqui o professor Jayro Pereira de Jesus se refere à elaboração de Henriques (2016, p.15): "Acabo esta jornada que me ocupou mais de um ano com a visão de que o racismo colonial foi um apagão e um
0 colonialismo trabalhou com duas ações, que chamamos de arrastão e apagão: árvore do esquecimento, por exemplo - porque aí se trabalha o esvaziamento dos elementos ontológicos (forma de ser, de se ver), se destrói isso, e depois vai contaminando com outros pressupostos, com outros valores, sobretudo com o maniqueísmo, porque com o colonialismo, a igreja foi fundamental. Ainda mais confundindo relações sociais com religião. Ação estruturante foi posta na cabeça dos africanos (JESUS, 2017) ${ }^{53}$.

A compreensão dos efeitos desse processo de desontologização, nas diversas dimensões da nossa formação humana e nos diversos campos do conhecimento, é fundamental para alcançarmos o entendimento de outro aspecto das questões levantadas pelo professor Jayro Pereira de Jesus - expostas mais acima: "O que poderemos voltar a ser? Voltar a ser o que nos impossibilitaram de ser". O que nos remete à reflexão do processo que o mesmo chama de reontologização, e de como isto está vinculado à compreensão e à práxis da perspectiva afrofilosófica e afroteológica, presentes nas tradições de matriz africana (JESUS, 2020). ${ }^{54}$

Beatriz Moreira Costa, a Mãe Beata de Iemanjá, também diz muito sobre o significado do processo de reontologização e da importância dos terreiros no processo de entrada na dinâmica filosófica africana: do ser-sendo.

O candomblé é meu empoderamento. É minha posse. É minha vida. É a fonte a que eu bebo, a minha água a qualquer momento. É a luz dos meus olhos. É o canto dos pássaros. É o lamento das nossas crianças do morro, da periferia. Dos homossexuais. É a minha estrada. É a encruzilhada que eu nasci. É o rio do Recôncavo, de Cachoeira, do Paraguassu. É a fome que eu passei quando criança. A boneca que eu não tive o direito de ter. O candomblé me deu oportunidade pra tudo isso. É a minha cultura. É a minha vida. 0 meu pai me tirou do colégio no 3 o ano, disse que filha dele não aprenderia a escrever, pra não fazer bilhete pra chamar homem pra trás da casa. Eu aprendi a ler com papel do lixo. Então o candomblé pra mim é isso. É a minha cultura. É o sangue do meu povo (COSTA, 2015). ${ }^{55}$

um arrastão ideológico, porque contaminou mentalidades de todos os quadrantes e durante séculos, de

umal forma que até hoje se verificam os seus efeitos".
53 Transcrição livre de entrevista do professor Jayro Pereira de Jesus, realizada por Ricardo Brasil.

54 Reflexões apresentadas pelo professor Jayro Pereira de Jesus durante o curso "Introdução ao Estudo da Filosofia e Teologia Africana, Afrocentrada da Tradição de Matriz Africana para Povo de Terreiro". da Filosofia e Teologia Africana, Afrocentrada da Tradição de Matriz Africana para Povo de Terreiro". zaro Ramos. 
Reontologização, que entendo estar presente no significado de Sankofa, no sentido de olharmos para trás, nos voltarmos para nossas raízes para compreender, resgatar, dar visibilidade e legitimidade a todas as contribuições e conhecimentos criados e desenvolvidos pelos povos africanos e afrodiaspóricos. Para aprofundarmos os desafios que estão postos em nosso presente e vislumbrarmos o fortalecimento de nossos potenciais e caminhos para avançarmos na superação desse sistemamundo ${ }^{56}$ estruturado pelo racismo.

Caminho que já começou a ser trilhado desde a constituição dos primeiros quilombos e nas diversas resistências dos povos africanos, indígenas e seus descendentes contra os escravagistas, os invasores, os racistas, os estupradores, os saqueadores, os torturadores e as supremacias brancas. Caminho que começou nas lutas contra a opressão, a exploração e as violências raciais de todos os tipos e dimensões.

Somam-se a essa trajetória as diversas ações, mobilizações e lutas históricas desenvolvidas no Brasil inteiro - por diversos coletivos de educadores, de estudantes e de militantes dos movimentos negros e indígenas -, que objetivam avançar no processo da (re)educação das relações raciais, visando à ruptura com a estrutura racista que constitui a formação social brasileira.

Na base da estrutura racista esteve, e ainda está, o extermínio físico, cultural, epistemológico e simbólico dos povos africanos, afrodescendentes e dos povos indígenas. 0 epistemicídio é uma das estratégias fundamentais de sustentação desse processo. Através deste, aliado ao mito da democracia racial ${ }^{57}$ e ao processo de embranquecimento - que marcam a nossa história -, as contribuições dos conhecimentos destes povos foram invisibilizados, ocultados, desconsiderados e apagados da nossa educação. Assim como, dos debates acerca da construção, do desenvolvimento, da diversidade e do avanço epistemológico e; dos currículos escolares - consolidando uma formação humana, predominantemente, racista, legitimando e naturalizando o genocídio destes povos. Desta forma, o eurocêntrismo ${ }^{58}$ 56 “O conceito de 'sistema-mundo' é uma alternativa ao conceito de 'sociedade'. Ele é utilizado para romper com a ideia moderna que reduz 'sociedade' às fronteiras geográficas e jurídico-políticas de um

57 Segundo Abdias Nascimento (2017, p. 47-48) “[...] erigiu-se no Brasil o conceito de democracia racociance deção concreta na dinâmica da dades de existência sem nenhuma interferência, nesse jogo de paridade social, das respectivas orinen raciais e étnicas". Florestan Fernandes (1989, p. 7) também se referindo a tal mito, afirma: "Essa é ideia corrente no exterior fomentada pela mesma hipocrisia que impera no Brasil: nós somos o pará́so tropical da convivência democrática das raças"

58 Segundo Anibal Quijano (2005, p.115): “A elaboração intelectual do processo de modernidade pro- foi imposto como única fonte de conhecimento científico. Isso atravessa toda a formação dos educadores e dos educandos.

Dessa forma, a colonização do conhecimento foi, e ainda é fundamental, para a sustentação do projeto de colonialidade que predomina atualmente. Daí a importância de entendermos a dinâmica das relações raciais em nosso país, a importância de decolonializarmos o conhecimento e o currículo. A implantação das leis no 10.639/03 (BRASIL, 2003) e no 11.645/08 (BRASIL, 2008) e a decolonialidade epistemológica são algumas das condições fundamentais para contribuirmos e avançarmos com a superação do projeto de dominação vigente em nosso país. Ter acesso a esses conhecimentos, recuperar, resgatar essa memória é crucial para rompermos, destruirmos e superarmos o projeto de dominação racista, classista, sexista e homofóbico que nos atravessa, que nos implica, que nos violenta, que nos desumaniza cotidianamente.

Nossa história (povos africanos, afrodescendentes e indígenas) sempre foi de luta e de resistência. Ainda hoje, 132 anos após a chamada 'Abolição da Escravidão', não obtivemos a abolição da condição de "condenados da terra" (FANON, 1968). Apesar de tudo, da fragilidade da democracia construída em nosso país - e do que isso tem significado historicamente em termos de perpetuação de violências em diversas dimensões em relação ao nosso povo seguiremos, como desde sempre: lutando...! Como desde sempre, entendendo que: Esperança, teu nome é luta! Como já escrito por José Carlos Limeira (2018) na estrofe final de seu poema "Quilombos":

Por menos que conte a história

Não te esqueço meu povo

Se Palmares não vive mais

Faremos Palmares de novo.

Considerações finais

Como professora de estudantes de ensino médio, considero fundamental a compreensão, em todos os campos de conhecimento, das diversas dimensões da

duziu uma perspectiva de conhecimento e um modo de produzir conhecimento que demonstram o caráter do padrão mundial de poder: colonial/moderno, capitalista e eurocentrado. Essa perspectiva e modo concreto de produzir conhecimento se reconhecem como eurocentrismo". 
colonialidade do poder, do ser e do saber - de forma a contribuir com a ruptura da estrutura curricular pautada na visão de mundo eurocêntrica, que nos excluiu e exclui do status de seres humanos, e que ilegítima, oculta e invisibiliza os conhecimentos e as produções intelectuais africanas e afrodiaspórica, através do epistemicídio e do menticídeo ${ }^{59}$.

Como educadora numa escola pública que forma profissionais para a área da saúde, destaco a importância da contribuição que o acesso às narrativas, aos conhecimentos e as epistemologias que advém das tradições de matriz africana pode proporcionar à compreensão das práticas de saúde, nos campos da promoção, da prevenção e da recuperação desenvolvidas nos terreiros, de forma a fortalecer e dar maior visibilidade aos conhecimentos sobre o cuidar da saúde nesses espaços.

Portanto, considero que desconstruir a farsa da teologia judaico-cristã e apropriar-se da filosofia, da epistemologia e da ética presentes nas tradições de matrizes africanas são questões fundamentais para ampliarmos nossa capacidade de compreender as leituras, as diversidades e formas de ser e existir nesse mundo e darmos continuidade ao enfrentamento a todas as violências produzidas pelo racismo que incidem sobre nós, nas dimensões física, psicológicas, emocionais, culturais, estéticas, epistêmicas, religiosas e tantas outras. Dar continuidade ao fortalecimento, como afirma Abdias Nascimento (1980, p. 22), “[...] da plena consciência do negro de que somente poderá ter um futuro, quando houver a transformação de toda a estrutura do país, em todos os níveis: na economia, na sociedade, na cultura e na política [...]". Somente assim, ainda segundo este autor, a população negra terá um futuro, num país no qual:

[...] Para os africanos escravizados assim como para os seus descendentes libertos', tanto o Estado colonial português quanto o Brasil - colônia, império e república - têm uma única e idêntica significação: um estado de terror organizado contra eles (NASCIMENTO, 1980, p. 261).

Como praticante de religião de matriz africana, entendo também que

59 Abdias Nascimento $(1980$, p. 25) utiliza esse termo para referir-se aos processos que, segundo ele, vão além do preconceito de cor, da discriminação e da segregação raciais: "[ "] os supremacistas brancos e brancóides manejam simultaneamente outras ferramentas de controle social do povo negro, exercendo sobre ele constante lavagem cerebral, visando entorpecer ou castrar sua capacidade ne raciocínio sobre ele constante lavagem cerebral, visando entorpecer ou castrar sua capacidade de raciocínio [.... tégia do seu aniquilamento total [...]". o diálogo e a apropriação, e/ou o aprofundamento, destas reflexões entre o povo de terreiro são fundamentais para que possamos nos instrumentalizar mais ainda, e multiplicar o conhecimento acerca das filosofias, das narrativas e das epistemologias advindas de nossos ancestrais. Filosofias, narrativas e epistemologias vivas e praticadas no chão de nossos terreiros que, desse modo, reforçam o combate ao racismo religioso ${ }^{60}$, à violência epistêmica e ao racismo epistêmico ${ }^{61}$, fortalecendo assim nossa caminhada no processo de reontologização, de nossa maior compreensão de existência de ser-sendo. Esse movimento nos fortalece e nos chama cada vez mais para o compromisso e a coerência, "o pensar fazer-sendo", com a totalidade (filosófica-ontológica-epistêmica) afrocentrada, como afirma Jayro Pereira de Jesus (LOPES, 2020).

\section{Referências}

AKOTIRENE, Carla. O que é interseccionalidade?. Belo Horizonte: Letramento: Justificando, 2018. (Coleção Feminismos Plurais).

BERNADINO-COSTA, Joaze; GROSFOGUEL, Ramón. Decolonialidade e perspectiva negra. Sociedade e Estado, Brasília, v. 31, n. 1, p. 15-24, jan./abr. 2016.

BRASIL. Lei No 10.639, de 9 de janeiro de $2003 . \quad$ Altera a Lei no 9.394, de 20 de dezembro de 1996 que estabelece as diretrizes e bases da educação nacional, para incluir no currículo oficial da Rede de Ensino a obrigatoriedade da temática "História e Cultura Afro-Brasileira", e dá outras providências. Diário Oficial da União: seção1, Brasília, DF, ano 140, n.8, p.1, 10 jan. 2003.

BRASIL. Lei № 11.645, de 10 março de 2008. Altera a Lei no 9.394, de 20 de dezembro de 1996, modificada pela Lei no 10.639, de 9 de janeiro de 2003, que estabelece as diretrizes e bases da educação nacional, para incluir no currículo oficial da rede de ensino a obrigatoriedade da temática "História e Cultura Afro-Brasileira e Indígena". Diário Oficial da União: seção1, Brasília, DF, ano 145, n. 48, p.1, 11 mar 2008.

60 Segundo Lucas Obalera de Deus (2019, p.8), “[...] o racismo religioso é uma ferramenta teórico-política com rendimento analítico capaz de ampliar o significado e sentido das múltiplas violências perpetradas contra as comunidades religiosas de matriz africana”. E ainda: “[...] a gravidade e, sobretudo a especificidade da experiência de uma violência perpetrada contra as religiôes de matriz africana, que tem so res não o seu suster sós ná se circu silos valores, saber,

61 Refiro-me à elaboração de Quijano (2005, p. 110): “a incorporação de tão diversas e heterogêneas

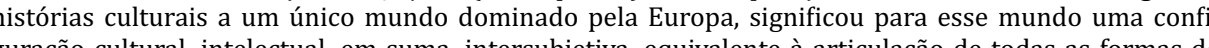
controle do trabalho em torno do capital, para estabelecer o capitalismo mundial. Com efeito, todas as experiências, histórias, recursos e produtos culturais terminaram também articulados numa só ordem cultural global em torno da hegemonia europeia ou ocidental. Em outras palavras, como parte orden cultural global em torno da hegemonia europeia ou ocidental. Em outras palavras, como parte do nov de controle da subjetividade, da cultura, e em especial do conhecimento, da produç̃̃o conhecimento". 
CARNEIRO, Aparecida Sueli. A construção do outro como não-ser como fundamento do ser. 2005. $339 \mathrm{f}$ Tese (Doutorado em Educação) - Programa de Pós-Graduação em Educação. Faculdade de Educação, Tese (Doutorado em Educação) - Programa

COLLINS, Patrícia Hill. Pensamento feminista negro: conhecimento, consciência e a política do empoderamento. São Paulo: Boitempo, 2019.

COSTA, Beatriz Moreira. Mãe Beata de Iemanjá. Entrevista a Lázaro Ramos. Programa Espelho, ano 10 2015. 23min.19s. Disponível em: https://www.youtube.com/watch?v=ZAGvOvqUBrs. Acesso em: 17 set. 2020.

CUNHA, Lázaro Raimundo dos Passos. Contribuição dos povos africanos para o conhecimento científico e tecnológico universal. [2006]. Disponível em: https://www.trabalhosfeitos.com/ensaios/ Contribui\%C3\%A7\%C3\%B5es-Dos-Povos-Africanos/706021.html. Acesso em: 17 set. 2020.

DEUS, Lucas Obalera de. Por uma perspectiva afrorreligiosa: estratégias de enfrentamento ao racismo religioso. Rio de Janeiro: Fundação Heinrich Böll, 2019. Disponível em: https://br.boell.org/sites/ default/files/caderno_religiao_e_politica_lucas_de_deus_boll_brasil_pdf. Acesso em: 30/09/2020.

DUSSEL, Enrique. 1492: o encobrimento do outro: a origem do mito da Modernidade: Conferência de Frankfurt. Petrópolis, RJ: Vozes, 1993

FANON, Franz. Os condenados da terra. Rio de Janeiro: Civilização Brasileira, 1968. (Coleção Perspectivas do Homem, v. 42. Série Política).

FERNANDES, Florestan. 0 significado do protesto negro. São Paulo: Cortez; Autores Associados, 1989.

GROSFOGUEL, Ramón. Para uma visão decolonial da crise civilizatória e dos paradigmas da esquerda ocidentalizada. In: BERNADINO-COSTA, Joaze; GROSFOGUEL, Ramón; MALDONADO-TORRES, Nelson (orgs). Decolonialidade e pensamento afrodiaspórico. 2. ed. Belo Horizonte: Autêntica, 2019. p. 5577.

GROSS, Eduardo. Consideracõos sobre a teologia entre os estudos da religião. In: TEIXEIRA, Faustino (org.). A(s) ciência(s) da religião no Brasil: afirmação de uma área acadêmica. 2.ed. São Paulo: Paulinas, 2008, p. 323-346,

HENRIQUES, Joana Gorião. Racismo em português: o lado esquecido do colonialismo. Lisboa: Tinta da China, 2016.

JESUS, Jayro Pereira de. Entrevista a Ricardo Brasil. CULTNE na TV. Acervo digital de cultura negra. [2017]. 14min.40s. Disponível em: https://www.youtube.com/watch?time continue $=3 \& \mathrm{v}=\mathrm{wKqW} 2 \mathrm{PCCN} 4 \mathrm{~g} \&$ feature $=$ emb $\_$logo. Acesso em: 14 ago. 2020 .

LIMEIRA, José Carlos. Quilombos. In: literafro - 0 portal da literatura Afro-Brasileira. Belo Horizonte: Faculdade de Letras da Universidade Federal de Minas Gerais, 2018. Disponível em: http://www. letras.ufmo br/literafro/autores/11-textos-dos-autores/784-jose-carlos-limeira-quilombos. Acesso: 17 set. 2020 .

LOPES, Claudemira Vieira Gusmão. 0 que fomos (África Pré-Colonial)? 0 que fizeram de nós (Colonialismo)? 0 que poderemos voltar a vir a ser (Educação para a descolonização dos saberes)? Revista Interritórios, Caruaru, PE, v. 6, n. 12, p. 280-298, 2020.

MALDONADO-TORRES, Nelson. Analítica da colonialidade e da decolonialidade: algumas dimensões básicas. In: BERNADINO-COSTA, Joaze; GROSFOGUEL, Ramón; MALDONADO-TORRES, Nelson (orgs) Decolonialidade e pensamento afrodiaspórico. 2. ed. Belo Horizonte: Autêntica, 2019. p.27-53.

MBEMBE, Achille. Crítica da Razão Negra. São Paulo: n-1 edições, 2018.

NASCIMENTO, Abdias. 0 genocídio do negro brasileiro: processo de um racismo mascarado. 2. ed. São

\section{Paulo: Perspectiva, 2017.}

NASCIMENTO, Abdias. 0 quilombismo: documentos de uma militância pan-africanista. Petrópolis, R] Vozes, 1980.

NASCIMENTO, Abdias. O quilombismo: documentos de uma militância pan-africanista. São Paulo Perspectiva; Rio de Janeiro: Ipeafro, 2019.

NASCIMENTO, Eliza Larkin. Introdução às antigas civilizações africanas. In: NASCIMENTO, Eliza Larkin (org.). A matriz africana no mundo. São Paulo: Selo Negro, 2008. (Coleção Sankofa: matrizes africanas da cultura brasileira, v. 1).

QUIJANO, Anibal. Colonialidade do poder, eurocentrismo e América Latina. In: LANDER, Edgardo (org). A colonialidade do saber: eurocentrismo e ciências sociais. Perpectivas latino-americanas. Buenos Aires, Argentina: CLACSO, 2005. p. 107-130. Disponível em: https://ufrb.edu.br/educacaodocampocfp/ images/Edgardo-Lander-org-A-Colonialidade-do-Saber-eurocentrismo-e-ciC3AAncias-sociaisperspectivas-latinoamericanas-LIVRO.pdf.

QUJJANO, Anibal. Colonialidade e classificação social. In: SANTOS, Boaventura de Sousa; MENESES, Maria Paula. (orgs.). Epistemologias do Sul. Lisboa: Almedina, 2009. p. 73-118.

WILLIAMS, Eric. Capitalismo e Escravidão. São Paulo: Companhia das Letras, 2012. 


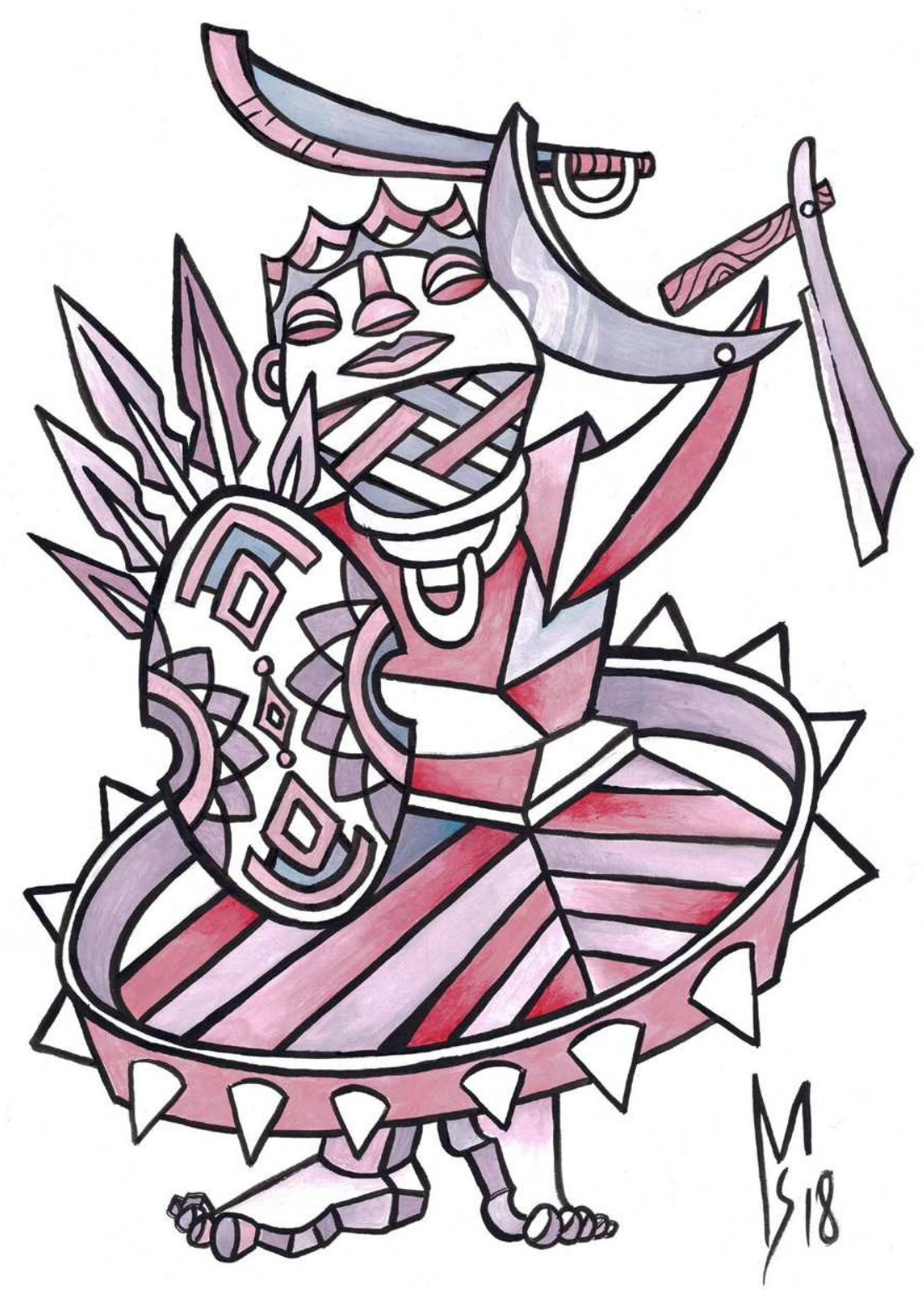

\section{$O b \grave{a}^{62}$}

Princípio arcaico do fogo. Do corte. Da roda. Anciã.

Aquela que está ligada ao princípio físico e fenomenológico das águas. Obà, símbolo genitor feminino pertence aos Irúnmalè do lado esquerdo - İyá-àgbà. Poder feminino - metade inferior do Igbá-odù, poder das Òrìșà femininas, poder das İyá-mi-àgbà.

Aquela que lidera a sociedade de E'léékò. Aquela que é İyá-ẹbé - título supremo das mulheres no culto aos Egúngún.

Obà - representação coletiva dos ancestres femininos

da sociedade E'léékò. Lẹ́sè Egún! Lẹ́sẹ̀ Òrìnà!

Tem sua prerrogativa mítico-social ressignificada na diáspora. É estrategista no conjunto das relações coletivas. Obà E’léékò!

62 Oríkì (louvação) para Ọbà, construído a partir das obras: "Agadá: dinâmica da civilização africano-brasileira”, de Marco Aurélio Luz (2000); “Os Nàgô e a Morte: Pàde, Àsèsè e o culto Égun na Bahia”, de Juana Elbein dos Santos (2012); e “Dicionário yorubá-português", de José Beniste (2011). 


\section{PADÊ DE EXÚ ABOLICIONISTA: INSURGÊNCIA NEGRA POR UM ABOLICIONISMO PENAL AFRODIASPÓRICO}

Luciano Góes

\section{“... Exu}

tu que és o senhor dos caminhos da libertação do teu povo

sabes daqueles que empunharam teus ferros em brasa

contra a injustiça e a opressão...

Zumbi Luiza Mahin Luiz Gama Cosme Isidoro João Cândido

sabes que em cada coração de negro há um quilombo pulsando

em cada barraco outro palmares crepita os fogos de Xangô

iluminando nossa luta atual e passada...".

(Padê de Exu Libertador - Abdias Nascimento)

Introdução

Laroyê... a benção aos mais velhos, a benção aos mais novos... ago!

A eficácia da democracia racista pode ser mensurada pelo domínio de uma das maiores populações negras do mundo, onde a hegemonia branca é tutelada por um sistema de controle instituído pela política colonial pharmakologica que nos condena à inimizade constante (MBEMBE, 2017). A manutenção da Casa GrandeBrasil demanda nosso extermínio, não apenas físico, como contenção de nossas insurgências, individuais e coletivas, e dentre as formas de controle formal sobressai a prisão, que reordenou violências e violações na defesa da hegemonia branca, e seu projeto de mundo, na transição de um império escravagista para uma república racista, inaugurando a grande-Senzala, caracterizada pela terceira maior população em situação de cárcere do mundo.

Através da teorização de abolição da prisão e do Direito Penal, por aparente perda de fundamentação e legitimação, pretendo demonstrar como o racismo antinegro, e sua natureza desumanizante, demanda um sistema de controle racial que recebe, constantemente, nova legitimação para manter intacta a arquitetônica racista, na qual a "crise" do cárcere não é, de modo algum, esporádica ou superável, mas reflexo do alcance de seus objetivos enquanto instrumento de dominação e extirpação da força física capaz de tensionar a opressão racial e transpor o limite insuperável do diálogo apaziguador neutralizante.

Por mais fundamental que seja, defender o abolicionismo penal em termos restritos à extinção das prisões, é ignorar as exigências de domínio intrínseco da estrutura racista brasileira e tutelar a supremaciabranca, pois éa própria branquitude que forja inúmeras prisões do Ser-negro diaspórico, com seu embraquecimento e assimilação pela normatização do narcisismo colonizante (FANON, 2008). É nesses termos que o criticismo branco se apresenta como "salvador da pátria" no cenário criminológico/abolicionista ao não conseguir ultrapassar os limites raciais, reforçando o racismo na exata medida em que o ignora enquanto fonte primordial de violência, replicando a ilusão de Thomas Mathiesen (2003) que, ao conceber o abolicionismo escravagista como verídico, toma-o como exemplo perfeito para alcance do "sonho abolicionista", não conseguindo entender que seu sonho é o inferno branco no qual vivemos, acorrentados em inúmeros cativeiros.

É aqui que risco o ponto ${ }^{63}$ deste brado abolicionista afrocentrado: naturalizar a prisão é legitimar todo sistema de (in)justiça colonial, é comungar com toda violência que é sua essência e que ela é incapaz de ocultar, é pactuar com toda desumanização que ela constitui, demanda e assegura, pois a prisão, como resposta "justa" do Direito penal declarado, é pilar de sustentação dos outros Direito penais (paralelo e subterrâneo), dinamizando, entre legalidades e constitucionalidade, nosso genocídio e epistemicídio que engendram o ordenamento jurídico que expressa a defesa da ordem racista, protegendo direitos fundamentais da branquitude.

Portanto, pensar na permanência do cárcere é descortinar os reais objetivos do sistema de controle racial brasileiro e sua função em uma democracia monocromática erguida nos entrelaçamentos do racismo e colonialismo, mantidos pelo enraizamento de colonialidades. Uma conjuntura que nos remete ao modelo de sociedade projetado sobre nossas cosmogêneses, arraigado em valores civilizatórios africanos tutelados por nossa ancestralidade, visceralmente contrários e opostos ao

63 Na Umbanda, Ponto Riscado é uma conjunção de linhas e símbolos que identificam a entidade incorporada, sua hierarquia e vinculação à determinado orixá. São instrumentos de segurança, riscados com Pemba, com funções específicas, determinadas pelas demandas conjunturais, fechando, trancand identidade abolicionista os comprometimento com minha sentido, o po 
modelo eurocêntrico, e justamente por isso são inconciliáveis, pois no trajeto pelo qual a branquitude chama seu projeto genocida de "progresso civilizatório", para o povo negro o único sentido é a morte.

Na margem brasileira, desde uma Criminologia da Libertação Negra, não apenas invertemos o sentido ao qual fomos sentenciados, mas o ressignificamos, uma vez que, na banda de cá da Calunga Grande ${ }^{64}$, encruzilhadas são lócus sagrados, moradas de Exú, mestre do poder da criação de epistemes subversivas e senhor da comunicação (des)ordeira dos (des)mandos racistas, abre caminhos e multiplica possibilidades para construção de uma perspectiva abolicionista afrocentrada com o qual se busca desfazer carregos criminológicos ${ }^{65}$ arriados pelo sistema de controle racial brasileiro. Transforma significados, transmutando a decolonialidade afrocentrada em projeto sankofaquiano ${ }^{66}$.

Exú é invocado como mensageiro do fim da hegemonia branca e início de um abolicinismo antirracista que, nos cruzos de rodas diaspóricas, toma corpo ao assumir posturas marginais que produzem espaços de resistência a partir da recusa à passividade inscrita no discruso branco cristão, ressignificando ideias, conceitos e conteúdos. Nesse sentido, esse ebó epistemológico (RUFINO, 2019) segue o traçado de Zé Pilintra que, no miudinho pelas esquinas sincretizadas, desce o morro e ganha o asfalto sem pedir licença, esboçando uma pedagogia malandreada que reconceitua a marginalidade, orientando a (sobre)vivência negra através das tentativas de dominação por meio de estratégias comprometidas com outros mundos, fazendo coro ao brado de liberdade sem concessão, reclamando o protagonismo emancipatório na luta negra pelo direitos a ter direitos.

Abolicionismo penal: conversa pra "cara pálida" dormir!

"Assumimos uma luta que nos vincula aos abolicionistas que se opuseram à escravidão. As instituições da prisão e da pena de 64 Oceano Atlântico.

65 Cargas multifatoriais com efeitos criminalizantes, instituídas pelo Direito penal do autor e atribuídas a corpos negros (e suportada por eles) que passam a ser identificados e transformados, facilmente, em criminosos, orientando prisões e mortes, ou seja, programando a seletividade racial.

66 Na filosofia africana, o ideograma Sankofa, integra o Adrinka, conjunto de símbolos de origem Akan (idental, sobretudo Gana e Costa do Marfim). A palavra pode ser lida como "volte pegue" (san - voltar, retornar; ko - ir; fa - olhar, buscar e pegar), já simbolicamente, é representada por um pássaro com sua cabeça virada para trás pegando um ovo de suas costas. morte são os exemplos mais óbvios de como a escravidão continua a assombrar nossa sociedade."

(Angela Davis)

O aporte instrumental construído pela Criminologia de base materialista (Crítica e Radical) desmascarou (quase) toda a legitimação do sistema de justiça criminal desde sua concepção que, sob os auspícios filosóficos iluminados, professava a contenção do poder punitivo lastreada por direitos e garantias (materiais e processuais) fundamentais, conferindo, ao menos na aparência, a vitória da "civilidade" sobre a "barbárie", a ponto da discursividade jurídico-dogmática, hoje, não se sustentar por seus próprios fundamentos.

Deste panorama, surge o Abolicionismo Penal propondo contração, extinção do ordenamento jurídico penal e seu aparato punitivo, pautados pelo Direito Penal que tem na prisão a resposta exclusiva perante o universo criminalizante (legislação penal), não por outro Direito Penal, mas qualquer coisa melhor, diagnóstico resultante do encadeamento sistêmico de sua programação seletiva (que expõe sua falácia e falência a partir de uma crise genética que o torna um embuste penal ${ }^{67}$ ), dada sua excelência em agir desigualmente, mantendo as desigualdades nas sociedades pela exclusão (BARATTA, 2011).

A legitimação teórica do cárcere (ainda) é extraída das teorias tipo "res" (BATISTA, V., 2011), ilusórias promessas explicitadas por sua inversão funcional, característica inata de não fazer (por impossível) o que declara e fazer (por ontologia) o que não declara (ANDRADE, 2012). É essa “ambiguidade” que garante o imprescindível apoio da (falsa) função simbólica das prisões, da qual emerge o amparo público ao incutir no imaginário coletivo a segurança (de quem? pra quem? e, por fim, contra quem?).

Assim, o abolicionismo penal, delineado aqui genericamente, sugestiona alternativas político-criminais para a resolução dos conflitos de modo inclusivo, tendo em vista que o Direito Penal não resolve nenhum problema, apenas exponencializa os problemas, mantendo os radicais e potencializando os derivados. É dizer que o

67 Utilizo "crise" no sentido que leciona Eugenio Raúl Zaffaroni, para quem o termo não indica, ou mesmo possa indicar, o momento profético que a teorização penalista se reflita em sua operalizaç̃o, um

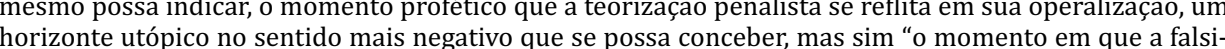
dade do discurso jurídico-penal alcança tal magnitude de evidência, que esta desaba, desconcertando penalismo da região" (ZAFFARONI, 1991, p. 15-16). 
Direito Penal é o problema para maioria dominada, eis que para a minoria dominante ele é a solução, mantendo e assegurando seus direitos e privilégios, por tratar-se de instrumento estatal de controle, através do qual manifesta o monopólio da violência legalizada, que não significa, de modo algum, legítima.

Alteração umbilicalmente ligada à transformação da própria sociedade, visando romper com o punitivismo capilarizado que demanda e confere expansão ao Direito Penal, transformado em instrumento de vingança por seu populismo, restando como função das penas, única e exclusivamente, a produção, consciente e insistente, de violência e violações. Como norte abolicionista, a frase de Louk Hulsman (2003), referência mundial sobre o tema, é dogmática e, até certo ponto, acalentadora:

Se afasto do meu jardim os obstáculos que impedem o sol e a água de fertilizar a terra, logo surgirão plantas de cuja existência eu sequer suspeitava. Da mesma forma, o desaparecimento do sistema punitivo estatal abrirá, num convívio mais sadio e mais dinâmico, os caminhos de uma nova justiça.

Mas, se nosso jardim estiver assentado em um solo tão sólido que ele próprio se transforma no obstáculo para o nascimento dessas novas plantas, o que fazer? Além disso, sabemos nem tudo que dá no jardim é flor, e nesse jardim central, ou espelhado nele, muitas plantas que brotam, por mais viçosas e exóticas que possam aparentar, se revelam como plantas carnívoras, ervas daninhas ou espécies predatórias.

Do enraizamento profundo nessa terra fertilizada por sangue negro, brotam incomensuráveis manifestações racistas, naturalizadas e violentas, mesmo que repletas de "boa vontade", sendo que as contribuições críticas que não conseguem ultrapassar tais barreiras reforçam e mantêm a ordem racial que pré-estabelece lugares, saberes e poderes, extraindo novos instrumentos a serviço do controle, domínio e opressão racial, perpetuando a hegemonia, tal qual a farsa da abolição escravocrata.

O sistema de controle racial formal brasileiro

"O escravo libertou-se; ficou ao sol por um breve momento; e então retornou à escravidão."

(W.E.B. Du Bois)
Há muito sabemos que as prisões foram concebidas como instrumento disciplinador para às fábricas no centro (Europa e EUA), pelo trabalho obrigatório, resultando em mão de obra dócil pronta para ser explorada, ideia basilar originária com a "correção" dos jovens prisioneiros, forçados a rasparem Pau-Brasil para tintura de tecidos na Rasp-huis de Amsterdã, final do século XVI da Holanda manufatureira (MELOSSI; PAVARINI, 2010, p. 43). Já no Brasil, a prisão com a função de docilizar/ domesticar foi adotada na pós-abolição da escravatura, inaugurando o encarceramento da massa preta com a re-escravização ${ }^{68}$, mas, ao contrário do sistema penal central, sua função não era modelar mão de obra para a indústria, mas de manutenção da exclusão do corpo negro no mundo branco, no qual ingressou não como parte do povo (elemento básico do conceito jurídico de Estado), mas como coisa.

A disciplina periférica sempre decorreu da manutenção da ordem racial alcançada por meio de violentas agressões físicas e mortes, meios indispensáveis no controle racial que tem como objeto a domesticação do corpo e da alma, instalando a desumanização no centro gravitacional de um sistema punitivista fundado no sonho senhorial que incutiu, em cada colonizado, o desejo incontido do poder "absoluto" sobre o corpo negro coisificado, tornando-se a "quintessência do mal" (FANON 1968, p. 39). A inumanização, lógica basilar do racismo, ratificada pela Igreja Católica que legitimou a escravidão africana, forjou a necropolítica como exigência do poder colonial que fez (e faz) do corpo negro seu pharmakon (MBEMBE, 2017, p. 82).

Da condição de imprescindível, para a concretização do projeto branco de mundo como homem-mineral (MBEMBE, 2014, p.78), o corpo negro foi metamorfoseado em proto-humano, cuja primitividade ameaçou o progresso "civilizatório", com descolonizações e abolicionismos, ao incorporar a periculosidade fantasmagórica que aterroriza os sonhos dourados da branquitude que o elevou à inimigo sempre pronto à destruir a (pós)modernidade. Necropoder, assim, não se instala na margem da lei, pois é clausula pétrea do Contrato Racial (MILLS, 1997) que fundamenta todo o corpus normativo pensado como "legítima defesa" da arquitetônica racista que exige um sistema de controle que neutralize os riscos e perigos advindos desses corpos insubmissos.

68 Código Penal de 1890, art. 45: “A pena de prisão cellular será cumprida em estabelecimento especial com isolamento cellular e trabalho obrigatorio, observadas as seguintes regras: a) si não exceder de um anno, com isolamento cellular pela quinta parte de sua duração: b) si exceder desse prazo, por um periodo igual a 4 a parte da durac̃ão da pena e que não podeŕ exceder de dous annos; e nos periodos sucessivos, com trabalho em commum, segregação nocturna e silencio durante o dia." [sic]. 
Desta feita, a falsidade discursiva da prisão no Brasil resta evidenciada desde sua concepção, eis que é impossível ressocializar quem nem ao menos foi socializado, re-educar que nunca foi educado, reintegrar quem jamais foi integrado em uma sociedade na qual somente foi parte enquanto objeto a ser explorado. Foi na iminência do confronto racial que o projeto abolicionista foi estrategicamente traçado como um "presente" embalado em papel jurídico, uma farsa onde a liberdade não seria conquistada pelo negro, mas um ato de "compaixão e humanidade" do branco, em termos de anistia, conciliação e colaboração entre as raças, ou seja, opressão, violência e resignação (ou morte!) ao povo negro.

Inevitável, a substituição da legalidade perdida pela legitimidade da arquitetura racista para remontar o sistema escravagista sob novos fundamentos, e o saber que estribou a face democrática da supremacia branca foi a tese da criminalidade nata de Cesare Lombroso, a partir da periculosidade exalada por corpos negros, conceito que os vinculou, de modo inquebrantável, ao elemento perigoso: o criminoso. Assim, foi gestado um modelo punitivo de viés acautelatório, objetivando a prevenção de um (im)possível crime: o Direito Penal do autor que prescrevia prisões anteriores ao delito e penas indeterminadas. Poucos anos após a abolição, em virtude do paradigma racista-etiológico, Nina Rodrigues defende a coexistência de, no mínimo, quatro Códigos Penais para a segurança da branquitude (GÓES, 2016).

o Direito penal do autor foi indispensável para manter as coisas em seus devidos lugares e recebendo o tratamento que merecem, instituindo a seletividade racial no interior do Direito penal declarado, isto é, no Código Penal republicano (que criminalizou todas as nossas rodas, objetivando impedir a reconstrução de Palmares), e aplicando a pena de morte aos corpos negros através do Direito penal paralelo, de responsabilidade das instituições policiais e legalizado por uma guerra racial declarada como "contra às drogas", iniciada em 1830, quando o "pito de pango" era comercializado nas pharmácias, o boticário era multado, enquanto o negro, escravizado ou livre, era preso (BARROS; PERES, 2011).

Nossa declaração de guerra se deu em 1930, com o combate ao "comércio" e uso do "fumo de negro" que justificou as práticas punitivas e criminalizações do nosso sistema de controle racial a título de "saúde pública", subsidiada pelo paradigma racista-etiológico que propagou a potencialidade da periculosidade negra inata, assim como aconteceu com o álcool ${ }^{69}$. Nesses termos, o problema da nossa "guerra contra às drogas" não é o proibicionismo, mas sua programação racista, pois no século XVII, o traficante branco não representava nenhum risco à sociedade, mas apenas o usuário negro, hoje, as posições foram trocadas, quem era usuário é traficante e deve ser morto quando avistado ou, preso (que não exclui a possibilidade de morte posterior).

A (in)diferença entre as figuras se relaciona, proporcionalmente, com o (quase) monocromático sistema de (in)justiça a partir da mobilização de aportes criminológicos por todas e todos que integram a estrutura punitivista, permitindo expressões de seus próprios racismos por trás da imparcialidade e livre convencimento, escamoteados na escolha de bens jurídicos que merecem tutela. No contexto de guerra cotidiana, um sistema jurídico racista e de exceção da humanidade permite, sem qualquer afetação aos direitos e garantias fundamentais, a aniquiliação do inimigo sob o pretexto de promoção ou resgate da paz e segurança pública, cujo preço é pago em quantidade de corpos negros.

Assim, se o projeto de embranquecimento, pelo extermínio direto, possibilitou a redenção de $\mathrm{Cam}^{70}$, o Estado brasileiro substituiu aquela maldição pela do Conde Drácula, sob a qual a "saúde pública" necessita de sangue (negro) que lubrifica as engrenagens da sistemática (in)constitucional exterminante, endossada pelo Judiciário, demonstrando que nossa "justiça" é juramentada com seu símbolo, uma mulher branca europeia, cujo olhar colonizante não encontra qualquer obstáculo, deslocando o fiel da balança de acordo com a melaninocracia ${ }^{71}$. Nesse sentido, a guerra "às drogas" resta perdida, se, e apenas se, correlacionarmos seu fundamento declarado à estratégia adotada, uma vez que, em seu objetivo (nada) latente o sucesso é absoluto: o extermínio do "traficante", demônio incorporado por corpos facilmente encontrados em toda e qualquer esquina marginal(izada).

Nosso sistema de controle racial encontra na periculosidade seu eixo gravitacional por decorrência da gênese escravocrata sob a lógica da inimização. A 69 A criminalização dos negros, pelo uso do álcool, foi estabelecida pelo Código penal a título de punição pela vadiagem. Em 1893, o Decreto-Lei no 145 , autorizou a criação de um estabelecimento prision 70 "Aluñ à "A Redenc̃o de Ca" do artis

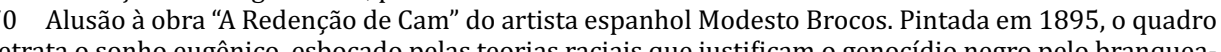
orias raciais que justificam o genocídio negro pelo branqueamento gradual implementado pela miscigenação, através de famílias interraciais.

71 Distribuição de privilégios ou discriminação de acordo com a quantidade de melanina. Pautada sobre os extremos re rias, quanto menos melanina e portanto, mais próximo ao menco mas privilégios (o que não significa imunizac̃a a racismo), por outro lado, quanto mais melanina mais discriminaça 
produção de mortes negras é inerente às sociedades que serão genocidas enquanto não confrontarem suas matrizes racistas, ou seja, a própria democracia é obstáculo, pois "se a democracia é verdadeiramente incapaz de resolver o problema racial, a questão é desde logo perceber como poderá a América livrar-se dos Negros" (MBEMBE, 2014, p. 149). Assim, não apenas os limites da democracia racial restam explícitos, como também do próprio conceito de democracia.

Enunciando a regra básica de nosso sistema punitivo democrático, o Direito penal do autor, nosso carrego criminológico arriado em terreiro colonial, se perfaz enquanto programação que incute o racismo em nossos sistemas penais formais, caracterizados pela seletividade racial que resulta em genocídio e encarceramento. Um ideário que não pode ser compelido pelos Direitos Humanos que resta repelido pela animalidade tornada signo negro, imiscuída em sua construção e sinônimo de risco à humanidade, eis que: "o direito é [...] uma maneira de fundar juridicamente uma certa ideia de Humanidade enquanto estiver dividida entre uma raça de conquistadores e uma raça de servos. Só a raça de conquistadores é legítima para ter a qualidade humana" (MBEMBE, 2014, p. 111).

A racionalidade objetificante do sistema punitivo "democrático" brasileiro é legitimada e legalizada com objetivos de (re)afirmação da humanidade branca, fazendo da desumanização negra não apenas sua característica inafastável, mas sua própria razão de existir. Entretanto, em que pese a importância do cárcere e da necropolítica, a funcionalidade dinâmica do sistema de controle racial brasileiro imprescinde da invenção de instrumentos de controle informais, invizibilizados, mas tão violentos quanto as formas explícitas. Assim, uma proposta abolicionista, comprometida com as mudanças urgentes do realismo marginal racial brasileiro, não pode se restringir ao cárcere, sob pena de suscitar a reorganização da dominação e (re)fortalecimento do complexo sistema aprisionante inato ao racismo antinegro.

O sistema de controle racial informal: o direito penal racial subterrâneo

"Nossa fala estilhaça a máscara do silêncio."

(Conceição Evaristo)
Por mais eficazes que sejam nossos instrumentos de controle formais, o sucesso absoluto do sistema de controle racial brasileiro é devido ao aparato informal, constituído por instrumentos que garantem a supremacia branca, e seu domínio sobre a segunda maior população negra do mundo. Nessa conjuntura, a necropolítica de Achille Mbembe deve ser complementada pelas dimensões genocidas expostas por Abdias Nascimento (pois ultrapassam, em muito, a morte física) a partir das quais teremos um panorama das violências que constituem a negritude brasileira, em termos de construção de identidades afrodiaspóricas desde suas matrizes, ou seja, arraigadas em epistemes civilizatórias africanas.

0 processo de conscientização da radicalidade do sistema de controle é obstaculizado, a todo custo, por seu âmbito informal que naturaliza a dominação. Sobre estas bases, emerge a Criminologia da Libertação de Lola Aniyar de Castro que salienta o caráter complementar dos instrumentos de controle informal e formal (Direito penal), cuja atração pela violência ofusca a preponderância do sistema informal (educação, religião e meios de comunicação) em suas formas de socialização da ideologia dominante, ou seja, produção de uma falsa realidade e ausência de consciência sobre a ordem. (CASTRO, 2005, p. 39).

Mirando nos conflitos de classes, Lola adverte que, sem compreendermos como ideologias são transmitidas pelas agências informais (objetivando obediência, submissão e consenso em torno dos valores dominantes essenciais), não entederemos o funcionamento no plano formal, responsável pela socialização secundária imposta pelo aparato penal quando a socialização primária fracassa, produzindo condutas desviantes que culminarão em carreiras criminosas, resultado da violência implícita complementada pela explícita, alternadas entre o aparente e o subterrâneo (situado no invizibilizado, nas entrelinhas).

Um aspecto muito importante dessa perspectiva criminológica é a ampliação da criminalização, alocando-a no interior de processos informais de controle, podendo-se falar, então, de seletividade informal que produz estigmatização, conformação ou desvio diante de padronizações e estereótipos e distribuição de acessos a direitos vitais. Tais programações são relegadas à desimportância pelo sistema penal quando, na verdade, são seus fundamentos, fazendo do funcionamento do Direito penal sua face aparente, enquanto que o controle informal é operacionado pelo "subterrâneo". 
Assim, a característica do sistema penal latino é sua dubiedade entre sistema penal aparente e sistema penal subterrâneo, que atua em todos os níveis de sociabilidade imposta pela classe dominante, fazendo-se presente, sobretudo, no não-dito. Nessa dinâmica, se estabelece as bases sólidas para processos de criminalizações de condutas:

Enquanto o sistema penal aparente formula expressamente o que é "mau" nos códigos através das incriminações, o sistema penal subterrâneo é o que decretará o que é "bom". E, consequentemente, quem são os "bons" do sistema social. Assim, encontramos uma não-criminalização de condutas de grave dano e custo social, características do papel das classes hegemônicas no sistema global. Em contrapartida, o sistema penal aparente criminaliza prioritariamente condutas que são mais facilmente localizáveis no âmbito das classes subalternas (CASTRO, 2005, p. 128)

O sistema informal é responsável pela "função reprodutora" do sistema de classes através da socialização de condutas que expressam aceitação, ou negação, da ideologia dominante, na qual integração requer controle, consenso e obediência, por isso o Cristianismo é fundamental, pois determina docilidade e acatamento: "aquele que obedece, isto é, que faz boa obra, não deve temer a autoridade. Produz-se assim uma confusão entre obediência e o bem, que nunca mais desaparecerá" (CASTRO, 2005, p. 156). Em seus termos geo-políticos descoloniais e epistemológicos, tal programa criminológico latino é sedutor, sustentando a libertação da ocultação das relações de poder ao defender que toda uniformidade cultural é sinônimo de autoritarismo, contraposto pelas religiões populares que trazem importantes informações sobre o sistema de controle.

Porém, existem nele várias armadilhas para o povo negro. 0 racismo, em momento algum, é abordado, se mostrando mais um discurso para a branquitude criminólogica manter sua hegemonia e nossa mumificação pela criminalização secundária, massificada por meio do estereótipo do criminoso, que permite a violação da presunção de inocência na operatividade do controle policial que nos faz clientes das "batidas". De importância incontestável, principalmente sobre o sistema de controle informal, a liberdade defendida renova as promessas abolicionistas oitocentistas, e com elas as senzalas que aprisionam a negritude, ignorando o racismo, e o genocídio que é seu resultado óbvio, materializando o epistemicídio e demais colonialidades, ou seja, a branquitude não se vê como fator de dominação, sucedaneo de criminalização e genocídio negro.

O extermínio de epistemes negras consolida a branquitude mediante mecanismos encravados no ser-negro, para sua alienação com vistas ao seu branqueamento, múltiplos mascaramentos que caracterizam o narcisismo eurocêntrico como única possibilidade de reconhecimento marginal, construindo várias prisões nas zonas brancas do "não-ser" (FANON, 2008). Estratégias que evidenciam a necessidade de apagamento da memória coletiva, enquanto direito à identidade do Ser-negro diaspórico, objetivando esquecimento, desencantamento e despotencialização (RUFINO, 2019, p. 15)

É, portanto, no sistema de controle racial informal que encontramos outras chaves para acesso às dimensões genocídas latentes, atreladas à desteritorrialização, que arrancaram e rechaçam nossas raízes africanas, nos formatando de acordo com ideologias brancas coloniais (nomes, sobrenomes, linguagem, cultura, religião, filosofias, etc). Foi nos terreiros, reconstituições quilombistas da territorialidade perdida e guardiões da centelha de vida negra, que a ancestralidade se fortificou, reconstruindo identidades afrodiaspóricas a partir de destroços e ecos vindo de além-mar, traduzidos pelo sincretismo, resultado da criminalização e imposição branqueante.

O controle branco sobre cosmogonias negras se empenha em reduzir todos os conhecimentos gerados por matrizes civilizatórias africanas à simplória ideia de "religião", caracterizando-as como saberes primitivos. Uma das estratégias branca de despolitização se apresenta pelo racismo religioso, cujos ataques se devem à todo complexo sistema de modos de vida africanos, e não ao mero caráter religioso, uma vez que, como estabelece Warderson Flor do Nascimento (2017, p. 54), o objetivo primevo da constituição dos terreiros é, extamente, a reconstituição de nossos modos de vida roubados, no sentido radical de religare:

[...] podemos dizer que essas "religiões" são muito mais que religiões, no modo como o ocidente as entende: são modos de vida que contêm em seu interior uma espiritualidade. Se são religiões - na medida em que se resgata o sentido de religare -, o são muito mais em uma conotação política, no sentido de reconstruir vínculos quebrados pelo racismo e pela colonização entre as pessoas africanas (e suas descendentes) e suas histórias 
pregressas ao processo escravizador que aconteceu na história de nosso país: tinham - e têm - a função de religar comunidades quebradas pelo violento processo que desumanizou e escravizou milhões de pessoas que foram forçadas a deixarem suas famílias, suas tradições, seus territórios.

Assim, a demonização das religiões de matriz africana não foi sem propósito, mas um estratagema branco de dominação e, sobretudo, neutralização da resistência negra que tem nos terreitos sua incorporação, transformando corpos negros e dotando-os de movimentos belicosos, determinando sua criminalização e inferiorização pela folclorização que a torna "um instrumento mortal no esquema de imobilização e fossilização de seus elementos vitais" (NASCIMENTO, 2016, p. 147).

Malandreando entre esquinas e encruzillhadas: estratégias negras marginais

\section{Laroiê, Mojubá, Axé!}

Salve o povo de fé, me dê licença!

Eu sou da rua e a lua me chamou

Refletida em meu chapéu

0 rei da noite eu sou

Num palco sob as estrelas

De linho branco vou me apresentar

Malandro descendo a ladeira... Ê, Zé

(G.R.E.S. Acadêmicos Do Salgueiro - A Ópera Dos Malandros)

A insurgência abolicionista negra volta-se às rodas cosmo-filosóficas diaspóricas, onde a resistência ancestral incorpora posturas que rompem os aprisionamentos colonialistas, sambando, debochadamente, sobre os carregos criminológicos originados de nosso sistema de controle racial, para (re)encontrar "novos" caminhos ao que é primordial no confronto com o racismo antinegro. Reconstruindo os cruzos, inverto sentidos, subvertendo lógicas coloniais, pois ali reside o dínamo de sua desordem, Exú, o movimento em deidade, o princípio de tudo e sem o qual nada é realizado, senhor dos caminhos de nossa libertação e das chaves mestras que abrem qualquer porta, mas também as trancam em nossa proteção.
0 Orixá mais próximo a nós, elo entre mundos cabaceiros, é o mais controvertido do panteão africano por ser o dono do verbo, a palavra em si, mestre da comunicação e, portanto, da encrenca pelos ditos mal-entendidos por ouvintes desentendidos. Cria ao desconstruir, ordena ao desordenar, sua potência inventiva insubordinável a processos criminalizantes se manifesta enquanto episteme ao reger a lei orúnica do retorno, que transcende e transmuta corpos resignados em desobedientes, podendo recompensar ou descompensar. Sob sua metodologia desprovida de qualquer resquício da moral cristã, nos vingamos e saímos dando, estrondosas e deliciosas, gargalhadas.

Crítico nato, questionador e transgressor de regras e comportamentos injustos (SILVA, 2015, p. 23), não foi sem propósito que Exú foi criminalizado, marginalizado e, por fim, demonizado na tentativa de aprisioná-lo, amordaçá-lo, neutralizando o manancial de força subversiva que é, tornado inimigo pela ideologia branca-cristã que o apresenta como o mal incarnado, espelhando, assim, o processo phamakológico racista que foi alinhavado à pele preta. Invocar Exú é cantar para que a estratégia racista suba, se dissipe no ar como a fumaça resultante do fogo que tacamos nas plantations epistemicidas (SIMAS; RUFINO, 2018), fertilizadas pelo racismo religioso, integrante do sistema de controle racial informal, que manipula a gramática de violência inscrita em nossos corpos igualmente diabolizados.

Transformador e transitante entre rodas (ainda criminalizadas pelos Direito penais por pulsarem heranças africanas), onde as filosofias de terreiro alimentam e sustentam nossa resistência que se abrigou no sincretismo como estratégia de sobrevivência e aquilombamento, Exú faz morada na Umbanda (que em quimbundo, significa "arte de curar"). Religião legitimamente brasileira e fundamentada na cosmopercepção ${ }^{72}$ africana, criada no início do século XX como reflexo da Le Áurea em Aruanda, concretizando a tão sonhada liberdade à velhos corpos negros ao abrir caminhos por incorporações dos Pretos Velhos, guias e mestres na quebra das correntes e prisões brancas dos discursos religiosos, sobretudo na fé resiliente, comprovada pela compulsoriedade de oferecer a outra face.

Criminalizada e perseguida, nossa ancestralidade salvaguardou os Orixás, e seus ensinamentos, em imagens católicas brancas para manter sua raiz, resultando 72 Segundo Oyèrónkẹ́ Oyěwùmí (1997, p. 39), a lógica colonial é fundamentada pela visão, hierarquizando e (de)marcando as diferenças corporeas a partir do olhar que se exclui, em detrian ${ }^{2}$ se dos demais campo visual, privilegiando outros sentidos, e/ou diferentes combinações deles. 
em embranquecimento, que abrigou nos ilês a branquitude e seu racismo, resultado da integração no mundo branco. De todo modo, a Umbanda, através de seu panteão, é uma projeção de nosso projeto de democracia multirracial, por sua natureza inclusiva e, nos caminhos transversados que a conceberam, o Orixá guardião dos caminhos à Ọrun transfigura-se em Entidade ${ }^{73}$, demarcando o território do povo da rua que por aqui baixa.

Chegando de viés pra sambar, Zé Pilintra, o malandro maneiro, nego bom de briga, boa praça e considerado por saber chegar e sair de qualquer roda, leva nossas demandas ao centro da discussão sem pulos, já que malandro não esperneia, sapateia no miudinho, balançando no ritmo da canoa. Símbolo máximo da malandragem, Seu Zé ensina ter jogo de cintura ao jogarmos com cartas marcadas, num jogo que a banca racista sempre ganha, e também a construir estratégias: subverter as regras (im)postas; esconder cartas na manga; blefar; e, obviamente, trapacear, eis que, se a cartada final é fatal, seja qual for a nossa jogada, temos a obrigação de desobedecer as normas de um jogo injusto, cuja aposta é vidas pretas aos milhares.

A pedagogia malandreada, assim, é fundamental à liberdade negra pela necessidade da criação de estratégias que garantam nossas (sobre) vivências ante às ininterruptas incursões que objetivam a aniquilação do potencial reivindicatório de nossas pautas e insurgências emancipatórias. Malandragem é a arte de inverter as investidas de controle sobre nossos corpos, produzindo contragolpes na malemolência abusada entre um miudinho dissonante e um cruzado sincopado, ritmados pela levada ancestral, conquistando espaços que fortalecem a resistência, ressignificando conceitos, conforme ensina Nêgo Bispo, onde nossa ancestralidade se apossa da palavra e a movimenta em nosso favor (SANTOS, 2019, p. 25), reinserindo conteúdo e direcionando a belicosidade inscrita em sua nova essência contra o sistema de controle racial, chumbando em seus pilares saberes palmarinos $^{74}$ que com poder de implosão.

Assim, sem alardes, sambando no fio na navalha, Seu Zé, expert na boemia, faz girar fora dos prumos instrumentos de controle, (re)quebrando seus mandos em esquinas onde a malandragem transforma vadiagem em vadiação (RUFINO, 2019, p. 142) na categoria que lhe é peculiar, alinhando elegância (que encanta os olhos brancos pela estética eurocêntrica), sorriso sarcástico e periculosidade preta 73 Mensageiros dos Orixás, também conhecidos como Falangeiros do Orixás.

74 Concebidos no Quilombo dos Palmares. (encoberta por seu terno branco). Malandragem é o improviso diante do cerco, o deslizar por uma saída inexistente (re)equilibrando-se rapidamente numa perna só para revidar, e revirar, a imobilização à resiliência anímica branca. Sacudindo a poeira, reafirmo, em tom de re-existência, o vínculo entre antirracismo e anticapitalismo, demonstrando a destruição fundada no âmago do projeto branco de mundo, e em seus axiomas dogmatizados, incluindo aquela ideia de "trabalho" essencial à uma dignidade caracterizada pelo consumismo irresponsável e predatório ${ }^{75}$.

Malandro nunca dorme ou anda só, e saravando por bandas desconhecidas, cujos propósitos foram acertados ontem pela pedra jogada hoje, cruzamos com a artimanha (arte e manha) de Luiz Antônio Simas (2020): “[...]jogar com o oponente e assumir o protagonismo do jogo, lidando com gramáticas corporais, sensoriais e sonoras que o oponente é incapaz de dominar. Se adequar para transgredir, gingar para se equilibrar, levar o jogo para o terreiro são táticas de pelintrações." A malandragem reescreve, aqui, a marginalidade como geradora de estratégias inventivas, energias vivas e irresignadas ante o destino traçado pelo sistema de controle racial, ditando enredos sobre rasteiras sutis com as quais tomamos o lugar do centro, arrancando das mãos brancas o protagonismo e hegemonia.

0 resgate de saberes ancestrais (que não podem ser enclausurados na discursividade, uma lição colonial) altera a perspectiva decolonial Sul-Sul em Morro-Asfalto que evoca sediciosidade, insurgência e revide a cada "tapa" como fundamentos de legítima defesa negra, princípios fundamentais da Criminologia da Libertação Negra que tem em Zé Pilintra seu representante legítimo, o mestresala que desce para firmar batucadas nas rodas racistas antinegras, evidenciando os instrumentos de controle racial brasileiro, mas a malandragem não se limita ao denuncionismo, pois ela risca pontos estratégicos para ludibriar, combater e desconstruir o sistema de dominação racista simbiótico a nossas mortes. Na pedagogia da malandragem somos conscientes de que o balanço indolente é mais do que necessário para invergar e não quebrar, não há "saída mágica" diante de apelos "Vidas negra importam" ou "Parem de nos matar" que ignoram métodos racistas que estabelecem em nossos corpos a presunção de periculosidade, fincada no próprio texto constitucional.

75 Na pedagogia da malandragem, a concepção de trabalho é reorientada, dando lugar à vadiação que encanta: "trabalhar pra que, trabalhar pra que... se eu trabalhar eu vou morrer"! (Trecho de um Ponto Cantado de Seu Zé Pilintra) 
Exú se manifesta aqui, como epistemologia e metodologia para o abolicionismo penal afrocentrado, ao abrir caminhos e possibilidades de quebra de todos os paradigmas centrais, que nos acorrentam, com o manuseio da lâmina em sua cabeça, tangenciando trajetórias de luta e resistência do povo negro que se movimenta, entre re-elaborações e reinvenções, nas malhas de suas existências para enunciar, ardilosamente, seu projeto coletivo de mundo, construído por cortes abertos no sistema de controle que existe pela, e para a, desumanização do corpo que se ergue e incita levantes.

Ejaculando o poder da criação, Yangi ${ }^{76}$ é a pedra fundamental do nosso abolicionismo, apontando outras possibilidades para a responsabilização de atos desviantes que, no conjunto das ações individuais que resultam na terceira maior população em situação de cárcere do mundo, explicitam as impossibilidades de resolução dos problemas que a estrutura racista produz. Exú vadeia nas encruzilhadas marginais, chutando carregos criminológicos, formais e informais, cuja potência ancestral faz brotar múltiplas epistemes antirracistas, pelas quais é possível ver (e caminhar por) caminhos invisíveis, improváveis e impossíveis se mantida a postura opressora e violenta racista/colonial/colonialista que caracteriza a base do mundo branco e seu sistema de controle racial que tem, como premissa fundante, o princípio do bem e mal, que representa seu olhar mesquinho, limitado a sua própria simploriedade, responsável pela propensão primitizante da cosmogênese africana.

Nos cruzos marginais, a mandinga gaiata ridiculariza a razão branca e faz sua (i) lógica binária, que sustenta o princípio da defesa social, perder o chão pois Exú é o Senhor da terceira cabaça, em suas mãos, tudo que pode ser bem, também pode ser mal, a palavra pode ser silêncio, a cura pode ser veneno, o visível pode tornar-se invisível, e isso tudo ao reverso, enfim, todo ponto final pode ser reticencias, projetando infinitas formas de novos, e inesperados, inícios. 0 malandro de gorro bicolor, que confunde olhares irresponsáveis e desatentos, atormenta, provoca conflitos e imprime novas possibilidades de resolução através de ensinamentos transmitidos por Mãe Beata de Yemonjá (2006, p. 99), nossos itans "têm os mesmos valores que os outros, e talvez até mais, pois são milenares."

Olojá, responsável pelo movimento e regente da lei do retorno, é o senhor do mercado onde a ordem é a troca, não a produção da morte como lucro, ontologia racista-capitalista e, portanto, norma básica do complexo industrial-prisional (DAVIS,

76 Na mitologia yorubana, quando Olòdumarè começou a respirar, transformou uma parte do ar em água, que ao se misturarem, deram origem a um montículo de lama, a proto-matéria em forma de rocha avermelhada que, ao receber o sopro de vida, tornou-se laterita, Exú primordial.
2018). No mercado-ojá, lugar de circulação de todos os elementos e bens (i)materiais vitais para a vida humana, trocas e compensações não são resumíveis ao aspecto financeiro, já que materializam a criação de laços comunitários e o agenciamento "das relações produtivas e das forças de produção para o fortalecimento coletivo dos laços estabelecidos por todas as componentes daquele terreiro ou de suas circunvizinhanças tradicionais" (NASCIMENTO, 2016, p. 34).

Ebó abolicionista à guisá de considerações infindáveis

\section{"Esù ó ó ni yágo loa}

Mo fori balé oo."77

Apontando para a impossibilidade da prisão em cumprir suas promessas, o abolicionismo penal provoca questionamentos sobre outras formas de solução dos conflitos sociais, demonstrando o comprometimento do sistema de justiça com as desigualdades resultantes do capitalismo, porém, ignorando o colonialismo e o racismo como suas raízes, reproduzindo a farsa abolicionista oitocentista e imunizando as estruturas racistas, e a própria branquitude, das mudanças necessárias para respostas não excludentes. Assim, nem todo abolicionismo é, de fato, abolicionista, a neutralidade racial é manifestação inequívoca do racismo na medida em que o mantém intacto e ainda o (re)fortalece!

Uma proposta abolicionista brasileira somente pode ser esboçada a partir de epistemes que combatam, e objetivem, a extinção do racismo enquanto estrutura de dominação resultante do trajeto genocida colonial que sintetiza hegemonia e monopólio branco, manifestado em políticas, normas e diretrizes racistas. 0 próprio modelo social eurocêntrico é obstáculo ao abolicionismo penal com seu monopólio sobre princípios, formas e conteúdo do "sistema de justiça" constituído como único e universal, característica que, desde sua etimologia, evidencia sua ordem excludente, pois como leciona Mogobe Ramose (2011, p. 10), é “uma composição do latim unius (um) e versus (alternativa de...), fica claro que o universal, como um e o mesmo contradiz a ideia de contraste ou alternativa inerente à palavra versus. A contradição ressalta o um, para a exclusão total do outro lado".

77 "Exu, abre-me os caminhos; Eu me prosto em reverência." 
Se a retomada do processo abolicionista oitocentista é premissa básica para um abolicionismo penal brasileiro, faz-se imprescindível que o trajeto seja pautado pelo rompimento com o colonialismo, e colonialidades decorrentes. $\mathrm{Ou}$ seja, por uma política de resgate e (re)afirmação da ancestralidade na busca por saberes que sustentam modelos de resolução de conflitos que não assegurem legalizem, e, sobretudo, potencializem, a necropolítica e nosso genocídio, sistemática engendrada pela prisão, que modela a tutela da arquitetônica racista sobre nosso encarceramento da massa, mantendo o domínio branco através de controle racial formal, legitimando o epistemicídio, o branqueamento e a assimilação, programas que integram o sistema de controle racial informal.

Alumiada por epistemes ancestrais, a Criminologia da Libertação Negra expõe as raízes racistas do sistema de controle racial brasileiro formado pelo Direito penal declarado, atravessado pelo Direito penal do autor que fundamenta e resulta no Direito penal paralelo (ambos mobilizados pela presunção de periculosidade negra), e pelo Direito penal subterrâneo, concretizando, de certa forma, o sonho punitivista de Nina Rodrigues, com práticas do desejo indizível de nossa democracia racista. Enfatizando, assim, o âmbito informal sublinho que seus modelos de socialização operam como métodos neutralizantes das insurgências pretas através das religiões brancas.

Do cruzamento das rodas rebentas de senzalas e quilombos, baixam existências que desafiam a racionalidade branca e (re)constroem inúmeros instrumentos para sua resistência, objetivando vivência plena para o povo negro, não mera sobrevivência ante a hostilidade branca. A malemolência de Seu Zé Pilintra subverte as investidas e esvazia as tentativas de aprisionamentos, ditando (com) passos malandreados enquanto estratégia de descadeirar mecanismos de controle, expressões do poder laminar e sedicioso que se observa na criação da capoeira, do samba, no sincretismo, nas ações afirmativas, nas caminhadas cruzadas que tramam os pontos de uma crítica da razão quilombista, incorporada nesse livro.

Se manifestando por epistemologias afrocentradas que abrem caminhos para um abolicionismo penal brasileiro, Exú também orienta exigências de uma justiça afrodiaspórica para uma democracia multirracial que recuse a violência colonial como resposta indistinta para as demandas da pluriversidade que constitui a margem brasileira. Utopia não é substituir as prisões por outro modelo de responsabilização, mas achar que sua conformação jus-política colonizante irá resguardar os direitos fundamentais do Ser-negro diaspórico, em termos cosmológicos africanos que concernem sentidos às experiências vívidas

Uma perspectiva abolicionista afrocentrada é capaz de pensar em um modelo de estrutura social na qual a coletividade possua sentido de abrangência tamanha que não exclua nada, nem ninguém, haja vista que essa é a natureza dinâmica do transito, constante e ininterrupto, entre a cabaça que une Aiyê e Orun, Orixás, humanos e demais seres (i)materiais são interligados, sintonizados e interdependentes, de modo que a exclusão compromete a comunhão do axé. Em termos de integralidade e importância da coletiva, a filosofia ancestral Ubuntu, uma das heranças mais preciosas deixadas pela mãe - África, reestabelece as bases sociais pelo comprometimento com o bem-estar coletivo, exaurindo conceitos como solidariedade e tolerância que, ao manter a hierarquização das relações, são falsos instrumentos de combate ao individualismo.

Como matriz civilizatória que confere sentido às existências negras diaspóricas, a imperatividade da coletividade, elo relacional que ordena o sentimento de pertencimento social a um todo (que exclui a estigmatização e criação do "outro", a individualidade e a meritocracia), e de responsabilidade da sociedade perante seus integrantes, fator indispensável para entender o erro individual como falha coletiva se propaga no "sou por que somos", e assim, somos somente enquanto coletividade. Sobre tais fundamentos, não é apenas possível pensar em um abolicionismo penal afrocentrado, mas sua viabilidade é inquestionável, uma vez que sua concretização integra a política sankofaquiana.

Certamente um "sonho" impossível se o pensamento colonizado for mantido, incluindo sua arrogância e "imbecilidade infantil de quem quer sempre ter a última palavra", que salvaguarda o ideário, introduzido a "golpes de pilão", de uma sociedade de indivíduos, como leciona o preto velho Franz Fanon, ao nos (re)lembrar de nossas organizações deliberativas democráticas, que rechaçam o maniqueísmo branco colonial com:

[...] a consistência das assembleias de aldeias, a densidade das comissões do povo, a extraordinária fecundidade das reuniões de quarteirão e de célula. 0 interesse de cada um não cessa mais de ser o interesse de todos porque, concretamente, serão todos descobertos pelos legionários e, 
portanto, massacrados, ou serão todos salvos. [...] Seja nas djemaas ${ }^{78}$ da África do Norte ou nas reuniões da África Ocidental, manda a tradição que os conflitos surgidos nas aldeias sejam debatidos em público. (FANON, 1968, p. 35-36)

Tais preceitos civilizatórios caracterizam o Quilombismo, projeto de nação que fundou nossa única tentativa de construção de uma sociedade verdadeiramente democrática, livre e de comunhão existencial (Palmares), orientado pelo associativismo que enlaça e consolida a unidade social e bem-viver. Abdias Nascimento (2002, p. 271), evidenciando nosso protagonismo para a reconstrução de um Brasil inclusivo, refere-se às inúmeras lições afro-brasileiras concretizadas em nossa experiência histórico-social:

Os negros têm como projeto coletivo a ereção de uma sociedade fundada na justiça, na igualdade e no respeito a todos os seres humanos, na liberdade; uma sociedade cuja natureza intrínseca torne impossível a exploração econômica e o racismo. Uma democracia autêntica, fundada pelos destituídos e os deserdados deste país, aos quais não interessa a simples restauração de tipos e formas calcadas de instituições políticas, sociais e econômicas as quais serviam unicamente para procrastinar (adiar) o advento de nossa emancipação total e definitiva que somente pode vir com a transformação radical das estruturas vigentes. Cabe mais uma vez insistir: não nos interessa uma proposta de adaptação aos moldes de sociedades capitalistas e de classes. Esta não é a solução que devemos aceitar como se fora mandamento inelutável. Reinvenção de um caminho afro-brasileiro de vida fundado em sua experiência histórica na utilização do conhecimento crítico e inventivo de suas instituições golpeados pelo colonialismo e o racismo.

A feitura de um Abolicionismo penal afrocentrado noticia, na encruzilhada marginal, um pluralismo jurídico condizente com uma democracia multirracial brasileira, resgatando práticas decoloniais concretas, de matrizes antagônicas ao Estado necropolítico modelado em pilares coloniais e legalizado pela supremacia branca, com vistas à sua implosão com a construção de inúmeras estratégias que 78 Principal órgão deliberativo de uma tribo do Povo Saharaui, composta por anciãos e lideranças eleitas, para discussãoo sobre normas, diplomacia e resolução de assuntos internos. Quando as questões eram supratribais, a Ait Arbein (Conselho dos Quarenta), composta por anciãos de várias tribos, era reunida. caracterizam a luta negra por liberdade, mobilizando o poder da comunicação (re) conceituada e subversiva, mostrando que, quem gargalha, ri muito melhor de quem ri por último.

\section{Saravá!}

\section{Referências}

ANDRADE, Vera Regina Pereira de. Pelas mãos da Criminologia: o controle penal para além da (des)ilusão. Rio de Janeiro: Revan, 2012.

BARROS, André; PERES, Marta. Proibição da maconha no Brasil e suas raízes históricas escravocratas. Revista Periferia, Vol. III, n. 2, 2011.

BARATTA, Alessandro. Criminologia crítica e crítica do direito penal: introdução à sociologia do direito penal. 6⿳a ed. Rio de Janeiro: Revan Instituto Carioca de Criminologia, 2011.

BARROS, André; PERES, Marta. Proibição da maconha no Brasil e suas raízes históricas escravocratas. Revista Periferia, Vol. III, n. 2, 2011.

BATISTA, Vera Malaguti. Introdução crítica à criminologia brasileira. Rio de Janeiro: Revan, 2011.

CASTRO, Lola Aniyar de. Criminologia da libertação. Tradução: Sylvia Moretzsohn. Rio de Janeiro: Revan, 2005.

DAVIS, Angela. Estarão as prisões obsoletas? Tradução: Marina Vargas, 2. ed. Rio de Janeiro, Difel, 2018.

FANON, Frantz. Os condenados da terra. Tradução de José Laurênio de Melo. Rio de Janeiro: Civilização Brasileira, 1968. (coleção Perspectivas do Homem, v.42).

FANON, Frantz. Pele negra, máscaras brancas. Tradução de Renato da Silveira. Salvador: EDUFBA, 2008.

GÓES, Luciano. A "traduç̃oo" de Lombroso na obra de Nina Rodrigues: o racismo como base estruturante da Criminologia Brasileira. Rio de Janeiro: Revan, 2016.

HULSMAN, Louk. CELIS, Jaqueline Bernart de. Penas perdidas: o sistema penal em questão. Tradução de Maria Lúcia Karan. 1를 ed. Rio de Janeiro: Luam, 1993.

MATHIESEN, Thomas. A caminho do século XXI — abolição, um sonho impossível? Revista Verve, no 4, 2003 , p. 80-111.

MBEMBE, Achille. Crítica da Razão Negra. Tradução de Marta Lança. Lisboa: Antígona, 2014.

MBEMBE, Achille. Políticas da Inimizade. Lisboa: Antígona, 2017.

MELOSSI, Dario; PAVARINI, Massimo. Cárcere e fábrica: as origens do sistema penitenciário (séculos XVIXIX). $2^{a}$ ed. Rio de Janeiro: Revan, 2010.

MILLS, Charles. The Racial Contract. Cornell University, 1997.

NASCIMENTO, Abdias. O genocídio do negro brasileiro: processo de um racismo mascarado. $3^{a}$ ed. São Paulo: Perspectivas, 2016.

NASCIMENTO, Abdias. O Quilombismo. $2^{\mathrm{a}}$ ed. Brasília/Rio de Janeiro. Centro de Estudos Afro-Orientais / Editora da Universidade Federal da Bahia EDUFBA, 2002 
NASCIMENTO, Wanderson Flor do. O fenômeno do racismo religioso: desafios para os povos tradicionais de matrizes africanas. In: Revista Eixo: Brasília-DF, v. 6, n. 2, 2017

NASCIMENTO, Wanderson Flor do. Olojá: Entre encontros - Exu, o senhor do mercado. Das Questões, v. 4, n. 1, 27 set. 2016.

OYĚWÙMÍ, Oyèrónkẹ́. The invention of women: making an African sense of western gender discourses. Minneapolis: University of Minnesota Press, 1997.

YEMONJÁ, Mãe Beata de. Caroço de dendê: a sabedoria dos terreiros. Como ialorixás e babalorixás passam conhecimento a seus filhos. Rio de Janeiro: Pallas Editora, 2006.

RAMOSE, Mogobe. Sobre a legitimidade e o estudo da filosofia africana. Tradução Dirce Eleonora Nigo Solis, Rafael Medina Lopes e Roberta Ribeiro Cassiano. In: Ensaios Filosóficos, Volume IV, 2011.

RUFINO, Luiz. Pedagogia das Encruzilhadas. Rio de Janeiro: Mórula Editorial, 2019.

SANTOS, Antonio Bispo dos. As fronteiras entre o saber orgânico e o saber sintético. In: OLIVA, Anderson Ribeiro; CHAVES, Marjorie Nogueira; FILICE, Renísia Cristina Garcia; NASCIMENTO, Wanderson Flor do. (Orgs). Tecendo redes antirracistas: Áfricas, Brasil, Portugal. Belo Horizonte: Autêntica, 2019.

SILVA, Vagner Gonçalves da. Exú: o guardião da casa do futuro. Rio de Janeiro: Pallas, 2015.

SIMAS, Luiz Antonio; RUFINO, Luiz. Fogo no mato: as ciências encantadas das macumbas. Rio de Janeiro: Mórula, 2018.

SIMAS, Luiz Antonio. Pelintríada: a epopeia do malandro (texto não publicado).

ZAFFARONI, Eugenio Raúl. Em busca das penas perdidas: a perda da legitimidade do sistema penal. Rio de Janeiro: Revan, 1991.

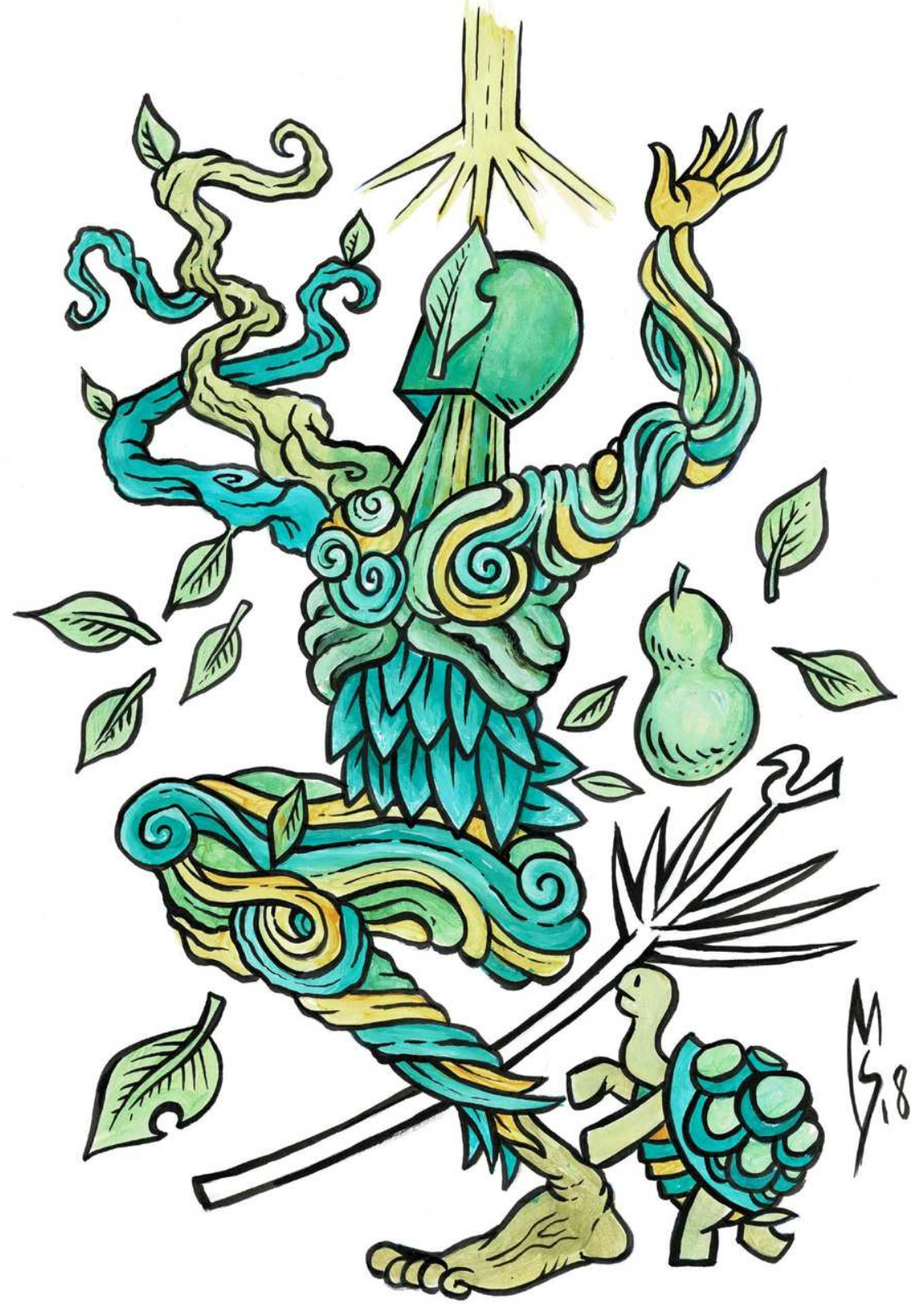




\section{DESCOLONIZANDO ORIS ${ }^{\circ}$ HEGEMÔNICOS E EUROCÊNTRICOS: O CANDOMBLÉ SULEANDO 81 UMA FORMAÇÃO ANTIRRACISTA}

Nathan Vinicius Nascimento Lopes Régia Mabel da Silva Freitas

\section{Òsányìn ${ }^{79}$}

Patrono dos vegetais.

Está ligado a todos os elementos da natureza

Mas tem na terra seu elemento principal.

Aquele que cuida da floresta,

$$
\text { da vegetação, }
$$

das folhas e de seus princípios ativos.

Ewé - folhas sagradas,

ewé afééfé - folha de ar, vento,

ewé inọ́n - folhas de fogo,

ewé omi - folhas de água,

ewé ilé ou ewé igbó - folhas da terra ou da floresta.

Ossányìn, aquele que tem poder sobre o èjè vegetal Kớsiewé, òrìsàkớsi!

Àșe poderoso no cuidado da existência.

Com ewé, mobiliza qualquer ação,

qualquer rito sagrado.

Aquele que cura.
Prelúdio

"Orí eni ní um ni j' obá" "A cabeça de uma pessoa faz dela um rei"

(Provérbio iorubano)

As epistemologias e práxis da Educação Básica à Superior ainda não foram efetivamente enegrecidas para o objetivo precípuo de promover uma educação antirracista neste Estado supostamente laico no qual ainda perpetua a dominação política e cultural colonialista. Hodiernamente, apesar da vasta produção e difusão de conhecimentos negrorreferenciados, a seletividade continua priorizando a soberania epistêmica da eurocentricidade em detrimento de atividades formativas afropluricentradas, repletas de estéticas e poéticas insurgentes.

Desconsiderando esuprimindooutros saberes, entreensinâncias eaprendências, reina o epistemicídio que se opõe a quaisquer outras versões epistemológicas. Em se tratando dos africanos que fizeram parte da humanidade histórica como vítimas subjugadas no secular sistema de opressão e dominação, vigora o amordaçamento de suas culturas e saberes. Como o binômio poder-saber é indissociável para nossa emancipação, perversamente desqualifica-se a intelectualidade azeviche.

Este artigo objetiva evidenciar o candomblé - uma referência identitária da herança religiosa ancestral - como um possível movimento descolonial contra o projeto epistemicida ainda vigente nos espaços formativos. 0 percurso metodológico é exploratório-descritivo, possui natureza qualitativa e dá-se através de revisão literária, em 80 Orí é uma palavra em iorubá que significa cabeça. Insta desde já salientar que todas as palavras de língua estrangeira que serão explicadas nas demais notas de rodapé são também de origem iorubana (BENISTE, 2011).

81 Neologismo com referência à obra Epistemologias do Sul organizada por Santos e Meneses (2010).
79 Oríkì (louvação) para ợsányìn, construído a partir das obras: "Agadá: dinâmica da civilização afride Juana Elbein dos Santos (2012); "Ewé Ò rì̀̇̀: o uso litúrgico e tarâêtutico e o culto Égun na Bahia", candomblé Jêje-Nagô", de José Flavio Pessoa de Barros e Eduardo Napoleão (2003); e "Dicionário yorubá-português", de José Beniste (2011). 
geral, negrorreferenciada, utilizando teóricos como Braga (1992), Carneiro (2005), Kileuy e Oxaguiã (2009), Machado (2013), Nascimento (1978), Nogueira (2020) entre outros.

Após, este introito denominado Prelúdio, há duas seções, a saber: (i) a priori, apresenta-se o candomblé como movimento de resistência cultural, religiosa e política ante o processo de subjugação imposto pelos colonizadores e (ii) a posteriori, discorre-se brevemente acerca do modus operandi da intolerância religiosa soteropolitana refutada pela nossa diuturna luta antirracista que prima por respeito, compreensão e conhecimento de nossos saberes ancestrais. Em seguida, constam as considerações finais, de alcunha Epílogo e, para encerrar, elencam-se as referências desta disruptiva produção científica.

“Êpa raío, machado e trovão/ epa justiça de guerreiro" 82 : a resistência cultural, religiosa e política do Candomblé

"Ki Ntoo bò Orìsà à è" "Portanto, adorarei as minhas origens"

(Provérbio iorubano)

Candomblé é o nome dado a religião que se formou no Brasil criada por negros oriundos de diversos países africanos, através do fenômeno sociocultural e histórico da diáspora azeviche. A palavra candomblé é de origem bantu: ( $c a$ [ka] - uso, costume, ndomb - negro, preto, e lé - lugar, casa, terreiro e/ou pequeno atabaque) e significa manifestação de negros em um determinado local. Segundo alguns pesquisadores, ela seria ainda uma modificação fonética de Candombé, um tipo de atabaque usado por angolanos; ou que viria de Candonbidé, que quer dizer ato de louvar, pedir por alguém ou por alguma coisa (NASCIMENTO, 2010).

A religiosidade de origem africana manifestada no Brasil possui diversas formas de representações e denominações, conforme origem e forma como esses africanos viveram no país; consequentemente, alterando-se em aspectos teológicos, linguísticos e de culto. Nos Estados de Pernambuco, Alagoas e Sergipe, as cerimônias africanas são denominadas Xangô, em São Luiz do Maranhão é o Tambor de Mina, Porto Alegre é o Batuque, a Macumba no Rio de Janeiro e o Candomblé na Bahia (PRANDI, 2001).

82 Verso da música Yáyá Massemba, composta por Roberto Mendes e Capinam, lançada em 2003, no disco Brasileirinho, de Maria Betânia.
Essa religião teve origem a partir da tradição de povos iorubás ou nagôs com influências de costumes trazidos por grupos fons, aqui denominados jejes e residualmente por grupos africanos minoritários (PRANDI, 2001), caracterizandose pelo culto a Orixás, Voduns e Inquices. Para Nascimento (1978, p. 102-103),

o Candomblé é o nome que recebeu a religião dos povos Yorubas, trazida da Nigéria para o Brasil. (...) 0 candomblé inclui variações de outros grupos culturais vindos da África, tais como os Ewe (Gêges) do Benin, Angola-Congo e outros ramos Bantu. Culto dos Orixás, o candomblé resistiu e conservou intato seu corpo de doutrina, sua cosmogonia e teogonia, o testemunho dos seus mitos vivos e presentes. 0 candomblé, cuja mensagem no Brasil é essencialmente a mesma como na África, significa uma religião na qual nem o inferno nem o diabo têm lugar e que não aflige a vida do homem com um pecado original do qual se deve purificar, mas que convida o homem a sobrepujar suas imperfeiç̃̃es graças ao seu esforço, aos esforços da comunidade e aos orixás.

Entre as principais etnias africanas que desembarcaram nas costas brasileiras sobrevivendo a diversas situações de repressão e maus-tratos diante das condições precárias de viagem nos navios negreiros durante o período escravagista destacam-se os bantus e sudaneses. Os bantus, representados pelo grupo étnico Angola-Congo, e por aqueles vindos da chamada Contracosta, são os angolas, congos, benguelas, moçambiques entre outros. Já os sudaneses, compreendem os povos iorubás ou nagôs da Nigéria (subdivididos em Ketu, Ijexá, Egbá, dentre outros), os Jejes (Ewe ou Fon) do Daomé (Benin), os Fanti e Ashanti da Costa do Ouro (Gana), os mandingas, originados dos Peuhl, e também os Haussas da Nigéria nortista (Idem).

Segundo Nascimento (1978, p.101)

desde os inícios da colonização, as culturas africanas, chegadas nos navios negreiros, foram mantidas num verdadeiro estado de sítio. Há um indiscutível caráter mais ou menos violento nas formas, às vezes sutis, da agressão espiritual a que era submetida a população africana, a começar pelo batismo ao qual o escravo estava sujeito nos portos africanos de embarque ou nos portos brasileiros de desembarque.

O candomblé é considerado uma religião monoteísta, haja vista que, dentro da sua estrutura filosófica e religiosa, entende-se que existe apenas um Deus criador, único 
supremo, o qual para as nações ${ }^{83}$ Ketu, Bantu e Jeje, é, respectivamente, Olórun, Zambi e Mawu. Entre o Deus supremo e os seres humanos, há os Orixás, os Inquices e os Voduns, denominação das divindades, que são os ancestrais simbolicamente divinizados e ligados à natureza, que viveram as mesmas experiências dos homens (BENITE et. al., 2019).

Dessa maneira, caracteriza-se pelo culto de elementos de personificação ligados à natureza, no qual os seus arquétipos estão relacionados às manifestações dessas energias chamadas de Òrì̀à ${ }^{84}$, da nação Ketu, que incorporam em seus eleguns $^{85}$. Tradicionalmente, o conhecimento acerca das divindades, dos segredos das ervas, da confecção das comidas e muito mais é transmitido pelos sacerdotes de forma visual e oral, muitas vezes adquiridos por meio da convivência com as pessoas mais antigas, donas de um grande saber que, dentro desse segmento, é passado de geração para geração (KILEUY; OXAGUIÃ, 2009).

Nas palavras de Machado (2013, p. 41),

os mais velhos aprenderam a fazer observando, imitando, admirando os seus mais velhos nos seus saberes e fazeres. Como que obedecendo a uma cadeia para a manutenção, continuidade e expansão da cultura do povo de santo cabe-lhes ensinar como aprenderam para que os mais novos possam dar continuidade à tradição.

O panteão de Orixás do Candomblé, dessa nação, é constituído por uma parcela tímida de 16 (dezesseis) das 4000 (quatrocentas) divindades existentes e cultuadas individualmente em África, cada um associado a elementos presentes no Àiyér ${ }^{86}$. Dentre eles, encontram-se Exu (os caminhos e a comunicação), Ogum (os minérios do ferro e a tecnologia), Oxóssi (a caça e a prosperidade), Omolu (as epidemias e a morte) e Ossaim (as plantas e a medicina) (KILEUY; OXAGUIÃ, 2009).

Outrossim, integram também Oxumaré e Ewá (a chuva e a transformação), Nanã (as águas pantanosas e a morte), Xangô (os trovões e a justiça), Obá (as águas revoltas e a guerra), Oyá (os ventos e o movimento), Oxum (as águas doces e a fertilidade), Logunedé (a vida e a dualidade), Iroko (as árvores centenárias e o 83 Verso da música Yáyá Massemba, composta por Roberto Mendes e Capinam, lançada em 2003, no disco Brasileirinho, de Maria Betânia.

84 Òrìsà ou Orixá são divindades representadas pelas energias da natureza, forças que alimentam vida na terra, agindo de forma intermediária entre Deus e as pessoas, de quem recebem uma forma de

.

86 Àiyé é mundo, plano terrestre ou planeta. tempo), Iemanjá (as águas salgadas e a maternidade), Oxalá (a criação e a paz), entre outras divindades (Idem). Insta salientar que o candomblé

não representa tão somente um complexo sistema de crenças alimentador do comportamento religioso de seus membros. Ele constitui, na essência, uma comunidade detentora de uma diversificada herança cultural africana que pela sua dinâmica interna é geradora permanente de valores éticos comportamentais que enriquecem, particularizam e imprimem sua marca no patrimônio cultural do país. E, diferentemente de outras formações religiosas, o candomblé é uma fonte permanente de gestação de valores e de promoção sociocultural que se sobrepõe à dimensão cultural-religiosa strictu sensu, plasmando os contornos da identidade do negro no Brasil (BRAGA, 1992, p. 14)

"Terreiro", "roça", "ilê" e "casa-de-santo" são algumas das diversas denominações mais conhecidas utilizadas para designar os espaços sagrados onde ocorrem as celebrações religiosas do candomblé. Elas são presididas pelas lideranças religiosas chamadas de "Bàbálórìsà87" ou "İyálórìsá88"; "Tata Nkisi" ou "Mametu Nikisi"; e "Doté" ou "Doné", respectivamente, de acordo com as três macronações supracitadas - Ketu cultuam os Orixás; Angola, os Inquices e Jeje, os Voduns. Para Kileuy e Oxaguiã (2009, p.43) esse templo

é a morada arquitetônica e sagrada das divindades, um conjunto onde agem as energias naturais, que faz a ligação física destas com os seres humanos. Um lugar público, aberto a todos que o procuram; (...) na nação iorubá as casas de candomblé denominam-se Ilê Axé; na nação fon, Kwe, Abassá ou Humpame; e Mbazi ou Canzuá, na nação bantu.

Além do/a sacerdote/sacerdotisa da casa, também chamados de "zelador(a) de Orixá", compõe a comunidade candomblecista os Ògás ${ }^{89}$, autoridades masculinas, que são auxiliares diretos e de posto hierárquico logo abaixo do/a Babalorixá/ Ialorixá, com atuações diversas como tocar atabaques, cantar para o siré Òrisà ${ }^{90}$, sacrificar animais, entre outras; as Ékèdis ${ }^{91}$, autoridades femininas, auxiliares, que desempenham a função de servir e cuidar dos Orixás - ambos não entram em transe.

87 Bàbálórisà ou Babalorixá é o sacerdote de culto às divindades denominadas Orixás. 88 İyálórìsá ou Ialorixá é a sacerdotisa do culto aos Orixás.

89 Ògá ou Ogã é um mestre, uma pessoa que se distingue na sociedade religiosa.

90 A palavra siré Òrisà ou xirê Orixá significa dança alegre dos Orixás.

91 Ékèdi ou Equede é a segunda pessoa hierarquicamente do terreiro. 
Outrossim, há os "filhos(as) de santo", chamados Iaôs ${ }^{92}$, pessoas que já passaram pelo processo de iniciação na religião e podem ou não entrar em transe (Idem).

Ademais, os Ėgbóns ${ }^{93}$, "irmãos(as) mais velhos", iniciados que já cumpriram todas as obrigações até concluir seu período de Iaô com a obrigação de sete anos, e que possuem a função de assessorar o/a Babalorixá/Ialorixá no desempenho dos rituais litúrgicos; e os Abiãs ${ }^{94}$, pessoas que estão no período de adaptação conhecendo preceitos e dogmas da religião do candomblé, fase de muita relevância, pois é através dela que o indivíduo tem a oportunidade de familiarizar-se com o terreiro e com a sua futura-família de axé (Idem).

Machado (2013, p 41) considera que "o espaço do terreiro compreende um lugar atemporal e possui métodos próprios de aprender e de ensinar." Kileuy e Oxaguiã (2009) asseveram que a iniciação no candomblé é um renascimento que ocorre em vida, no qual se renasce para o Orixá, ligando a vida física, no Aiyê, à sagrada, no Òrun ${ }^{95}$. Após a iniciação, as pessoas têm a capacidade e a possibilidade de ajudar a conduzir melhor o seu destino, sentindo uma transformação ao seu redor. Elas devem permitir que seu Orixá aja permanentemente no seu dia a dia, ajudando na construção de uma vida mais harmoniosa e próspera.

A ajuda mútua é basilar entre os membros das comunidades dos terreiros; estabelecendo, assim, estreitos laços de pertencimento. Kileuy e Oxaguiã (2009, p. 45) aduzem que eles são todos parentes míticos, "praticando uma comunhão integral e visceral com a ancestralidade", enquanto Bastide (2001, p. 63) rememora a instauração desse sentimento de fraterna coletividade desde o período seiscentista:

Se, de um lado, os sacerdotes ou sacerdotisas supremas têm autoridade absoluta sobre os membros da confraria religiosa que dirigem, de outro, têm também obrigações para com eles, tanto de assistência pecuniária quanto moral, o que, em plena Bahia, [tornou] os candomblés verdadeiras sociedades de socorro mútuo, de auxílio fraterno, que [manteve] o espírito comunitário africano.

Consoante Kileuy e Oxaguiã (2009, p. 45), essa comunidade "na sua vida em conjunto, produziu regras próprias para uma boa convivência, esquecendo-se das

92 Iaô ou iawo/sawo é uma pessoa que se iniciou nos mistérios do culto aos orixás.

94 Abiã ou Ėgbèrì Ògbèrì é a pessoa não iniciada nos mistérios da religião, ignorante de alguns assuntos, neófita.

95 Òrun ou Orum significa céu. diferenças sociais e intelectuais". Assim, como desde o sequestro do além-Atlântico as mercadorias semoventes foram propositalmente misturadas nos navios negreiros pelos caucasianos para que não estabelecessem laços, os terreiros tornaram-se mais um espaço de estratégia negra de resistência nos quais se subverteu a lógica colonizadora e onde se criaram elos políticos entre etnias desconhecidas e/ou adversárias.

Para Reis e Silva (1989, p. 09), já que os negros transformaram adversários naturais muitas vezes em aliados involuntários, "poucas instituições negras desenvolveram e aperfeiçoaram como o candomblé a sabedoria da negociação escrava". Esses autores consideram essa religião uma linguagem política devido ao estabelecimento de alianças que evidenciou a veia insurrecional desses agentes políticos com insurgentes determinações étnico-culturais, religiosas e de classe.

Nas palavras de Nascimento (2010, p. 939), "o desenvolvimento de manifestações sociais reconhecidamente tidas como herança da cultura africana, carregam em si lutas contra a dominação e resistências contra as imposições, o que repercute também no meio religioso". Assim, como mais um ponto estratégico para refutar o estrangulamento da sua condição humana, os negros transformaram seus templos religiosos em locais de mobilização política para a organização e desenvolvimento de projetos insurgentes com criatividade e inteligência.

Enfim, os terreiros são lócus de singulares trocas ancestrais nos quais se reafirmam as identidades política, cultural e religiosa dos negros sob a proteção espiritual de seus seres encantados, sejam Orixás, Inquices e Voduns. Parafraseando Reis e Silva (1989), em seus templos religiosos, eles, muito além de cantar, dançar, tocar e homenagear seus deuses, promoveram coesão social antecipando levantes e rebeliões; reafirmando, assim, o significado do verbo resistir.

"O batuque das ondas nas noites mais longas/

me ensinou a cantar" 96 : breve modus operandi da intolerância religiosa soteropolitana ante o xaxará ${ }^{97}$ antirracista

"Orìsà fún mi lókun láti jagun àti ségun" "Orixá torna-me forte para lutar e vencer"

(Provérbio iorubano)

97 Xaxará ou sàcásà é um bastão cerimonial utilizado por Omolu para limpar o ambiente e afastar doenças e impurezas espirituais (KILEUY; OXAGUIÃ, 2009). 
Apesar de toda essa magnitude ancestral com uma gramática própria de saberes práticos que ensinam a viver, contrariando ao direito fundamental de liberdade de crença consubstanciado na Constituição Federal, a perversidade do racismo religioso impera diuturnamente contra os candomblecistas. Essa religião brasileira de matrizes africanas - uma "amálgama de ritos, mitos e valores simbólicos de grande força espiritual" (BRAGA, 1992, p.13) - ainda neste século XXI é estereotipada, demonizada, considerada primitiva e sem ética.

Nogueira (2020) pondera que a intolerância religiosa é uma luta contra os nossos saberes ancestrais organizada e sistematizada com o escopo de extinguir nossa estrutura mítico-africana milenar que com maestria nos ensinou a ser, resistir e lutar. Ele locupleta que não devemos celebrar a ação de tolerar, já que não contempla a tríade respeitar, compreender e conhecer, julgando-a como mais um tentáculo do racismo - nesse caso, o religioso - que insiste em querer regular nossos singulares e tão idiossincráticos corpos, mentes, gozo e afeto.

Os dados nacionais, disponibilizados pelo Ministério da Mulher, da Família e dos Direitos Humanos que concentra denúncias de discriminação e violação de direitos por meio do Disque 100 - maioria candomblecista -, mostram que só no primeiro semestre de 2019, houve 354 notificações, o que representa um aumento de 56\% no número de denúncias de intolerância religiosa em comparação ao mesmo período do ano anterior, quando foram recebidas 211. Entre 2015 e o primeiro semestre de 2019, foram 2.722 casos - uma média de 50 por mês (BRASILDEFATO, 2020).

Em nível local, os agressores soteropolitanos intimidam, ameaçam e violentam física, moral e psicologicamente as lideranças e os adeptos, bem como destroem os elementos sagrados, depredam e picham os patrimônios. Para Carneiro (2005), trata-se de desqualificar nossas formas de conhecimento, desqualificandonos também, individual e coletivamente, como legítimos sujeitos cognoscentes, ocultando as significativas contribuições do continente africano e da diáspora africana para o patrimônio cultural da humanidade.

Nogueira (2020, p. 28) corrobora ao afirmar que

há um padrão de poder perpetrado pelo projeto de dominação europeuocidental que opera na produção contínua de violência, destruição, desvio e subalternidade sobre outros princípios explicativos de ordenação/ compreensão de mundo, dos seres e suas formas de saber. Trata-se da colonialidade do poder. A colonialidade do poder hierarquiza, classifica, oculta, segrega, silencia e apaga tudo que for do outro ou tudo que oferecer perigo à manutenção de um status quo, garantindo a perpetuação da estrutura social de dominação, protegendo seus privilégios e os de sua descendência e cristalizando as estruturas do poder oligárquico.

Ao tratar sobre os atos discriminatórios e a intolerância religiosa mister se faz trazer à baila a importância do dia Nacional de Combate à Intolerância Religiosa, 21 de janeiro, que representa um marco na luta ao respeito da diversidade religiosa, instituído por meio da Lei no 11.635/2007 em virtude da data de morte da Ialorixá Mãe Gilda de Ogum. A sacerdotisa do Axé Abassá de Ogum, terreiro localizado em Itapuã, Gildásia dos Santos e Santos, sofreu um infarto fulminante após ser vítima de intolerância religiosa ao ver sua imagem estampada em uma reportagem publicada pela Folha Universal.

Sob o título "Macumbeiros charlatões lesam o bolso e a vida dos clientes - 0 Mercado da Enganação Cresce no Brasil, mas o Procon ${ }^{98}$ está de Olho", a edição de no 390, de 1999, do jornal Folha Universal, veiculado pela Igreja Universal do Reino de Deus - IURD, de circulação nacional, utilizou a imagem de Mãe Gilda na capa, acusando-a de charlatanismo. Em razão disso, ela teve o seu templo invadido e vilipendiado, além de ser vítima de violência verbal e física. Consequentemente, haja vista sua saúde fragilizada, não suportou os ataques constantes, o quadro agravou-se e veio a óbito.

Em batalha judicial, a Justiça condenou a IURD e sua gráfica a indenizar a família da Ialorixá em 1,4 milhões de reais pelo uso indevido de sua imagem sendo um real por cada exemplar do jornal publicado com a matéria. Contudo, por unanimidade de votos, a 4⿳亠丷厂 Turma do STJ (REsp 913131) manteve a obrigação dos réus de pagar indenização aos filhos e ao marido da vítima, no entanto reduziu o valor para $\mathrm{R} \$ 145.250,00$, totalizando $\mathrm{R} \$ 20.750,00$ para cada herdeiro.

Em 2014, foi inaugurado no Parque Metropolitano do Abaeté em Nova Brasília de Itapoã, um monumento com o busto de Mãe Gilda em sua homenagem. Essa proposta foi idealizada por Jaciara dos Santos, sua filha biológica e atual dirigente do terreiro, para lembrar a história de vida da sacerdotisa e não permitir o esquecimento da manifestação de intolerância que teve como resultado seu falecimento. Atualmente, Mãe Gilda é considerada como um dos maiores símbolos da luta contra a intolerância religiosa no Brasil (CORREIO NAGÔ, 2016).

98 Programa de Proteção ao Consumidor. 
No ano de 2016, a estátua foi alvo de vandalismo ao ter parte da placa de informações quebrada e as plantas ao redor arrancadas por pessoas até então não identificadas pelas câmeras de segurança do local. Por conta desse não reconhecimento, a investigação foi interrompida sem conclusão (Idem). Em 2020, o monumento foi novamente atacado em plena pandemia à luz do dia; desta vez, o vândalo, que se dizia "a mando de Deus", apedrejou o busto danificando inúmeras partes (G1 GLOBO, 2020).

Apesar de o agressor ter sido preso em flagrante, a delegada, ao registrar o Boletim de Ocorrência, tipificou o crime como dano qualificado a patrimônio público, desconsiderando racismo e intolerância religiosa por alegar ausência de nexo causal. Ela o interrogou para saber se ele tinha algo contra o candomblé ou a Mãe Gilda e o acusado, obviamente, negou. Insta ainda salientar que ela recusou-se a entregar uma cópia desse documento à advogada do Axé Abassá de Ogum que foi à delegacia no dia do flagrante acompanhar o registro do crime (ALMA PRETA, 2020).

Em 2017, houve arrombamento e invasão do Hunkpame Savalu Vodun Zo Kwe - terreiro tombado com base na Lei de Preservação do Patrimônio Cultural em 2016 -, no Curuzu, na Liberdade durante uma operação no bairro. Doté Amilton Costa, sacerdote desse terreiro há 30 (trinta) anos, relatou que cinco policiais militares do Patrulhamento Tático Móvel (Patamo) pularam o muro, provocaram danos materiais e colocaram uma arma em seu rosto. A ação resultou em um pedido público de desculpas da Polícia Militar (A TARDE, 2017).

No ano de 2019, a estátua em homenagem à memória da Ialorixá do Ilê Axé Opó Afonjá, falecida em 2018, Maria Stella de Azevedo Santos ${ }^{99}$ conhecida como Mãe Stella de Oxóssi, localizada na avenida que possui o seu nome, foi vandalizada ao ser pichada e ter a placa com a marca da prefeitura arrancada. Acerca desse crime patrimonial de cunho racista, o vereador candomblecista e militante do movimento negro Sílvio Humberto, que registrou o Boletim de Ocorrência, afirmou que "a intolerância religiosa não nos vencerá" (A TARDE, 2019).

No mesmo período é possível citar também os ataques realizados à "Pedra de Xangô ${ }^{100 ", ~ m o n u m e n t o ~ s a g r a d o ~ t o m b a d o ~ p e l a ~ P r e f e i t u r a ~ d e ~ S a l v a d o r, ~ o n d e ~ f o r a m ~}$ 99 Mãe Stella de Oxóssi, Odé Kayode, foi uma das mais importantes Ialorixás do Brasil. Liderou um dos terreiros de candomblé mais tradicionais da Bahia, o Ilê Axé Opô Afonjá. Ela possui o título de Doutora Honoris Causa pela Universidade Federal da Bahia e pela Universidade do Estado da Bahia e nove livros publicados. Graças a essa produção literária, tornou-se membro da Academia Brasileira de pando a cadeira de número 33 que já teve Castro Alves como patrono (LITERAFRO, 2019). "Xnồ" é un conceito polissêmico e abrange o ter povos ca ç encontrados cerca de 100 quilos de sal (CORREIO, 2019). O Ministério Público da Bahia (MP-BA) informou que, além de apurar o caso, recomendaria ações concretas a serem tomadas pelo poder público municipal para a proteção desse patrimônio (G1 GLOBO, 2019); afinal, com mais de um século da suposta abolição da escravatura, é inadmissível a contínua subjugação das culturas negras.

Insta salientar que, além de ato de vandalismo contra o patrimônio público, jogar sal no monumento é considerado crime ambiental, já que o elemento afeta o solo e o lençol freático, impedindo a reprodução de espécies. Prática reincidente, a agressão representa o ódio religioso aos adeptos das religiões de matrizes africanas como forma de represália em razão dos rituais que acontecem no local. 0 elemento utilizado, para os evangélicos, sobretudo entre as práticas pentecostais, hipoteticamente tem o poder de "queimar", procedimento que gera uma espécie de "purificação".

Como o racismo religioso sempre atualiza as suas tecnologias, atualmente, os agressores estão considerando como perturbação do sossego alheio a suposta poluição sonora de terreiros gerada pela utilização de instrumentos musicais. Dentre as medidas impostas, temos a redução do número de atabaques, determinação de horários fixos para as celebrações e a obrigatoriedade de isolamento acústico. Esse retrocesso rememora o xangô-rezado-baixo, nos idos de 1912, quando as cerimônias religiosas afro-brasileiras foram interrompidas pela polícia e houve a apreensão de instrumentos sagrados.

Cabem aqui alguns questionamentos: as badaladas dos sinos das igrejas para anunciar quando uma missa vai começar, os toques para avisar acerca das horas, além dos diferentes toques para informar algum acontecimento importante para a Igreja Católica não geram poluição sonora? 0 som mecânico e instrumentos musicais de cultos religiosos evangélicos, a exemplo dos neopentecostais, na prática do proselitismo religioso, que também são visualizados em praças públicas, ônibus coletivos e hospitais, também não incomodam o silêncio de outrem? Por qual razão apenas os candomblecistas são obrigados a cumprir medidas restritivas, considerados perturbadores do sossego alheio?

Esse projeto colonial que anula a intelectualidade negra, obstaculizando a sua trajetória como sujeito de conhecimento, utiliza "diferentes mecanismos Angola e Jeje. Entenda-se por Pedra de Xangô, Nzazi, Sogbo, do Buraco do Tatu, da Onça e do Ramalho como uma demonstração do sentimento de pertença que as nações Ketu, Angola e Jeje e demais segmentos nutrem para com a pedra (SILVA, 2017). 
de deslegitimação do negro como portador e produtor de conhecimento e de rebaixamento da capacidade cognitiva pela carência material" (CARNEIRO, 2005, p 97). Como "a diversidade epistemológica do mundo continua por construir" (SANTOS; MENESES, 2009, p. 44), urge extirpar essa secular imposição do embranquecimento cultural que nos marginaliza, discrimina e criminaliza.

Nogueira (2020, p. 63) exprime que a subalternização “leva ao epistemicídio e ao apagamento daquilo que a hegemonia não suporta ver vivo, humano e verdadeiro. No seio da negação de conhecimentos, saberes e culturas não assimiladas pela cultura branca/ocidental está a colonialidade do poder". Carneiro (2005, p. 97) ratifica:

O epistemicídio é, para além da anulação e desqualificação do conhecimento dos povos subjugados, um processo persistente de produção da indigência cultural (...) [que] fere de morte a racionalidade do subjugado ou a sequestra, mutila a capacidade de aprender (...) com comprometimento da autoestima pelos processos de discriminação correntes no processo educativo.

Da classificação como selvagens e inferiores, que sustenta uma inferioridade dos africanos e seus descendentes, no século XVI, até os mais modernos e poderosos meios de controle social e cultural da atualidade como o aviltamento ao candomblé - "o ventre gerador da arte afro-brasileira" (NASCIMENTO, 1978, p. 103) - o racismo insiste em tentar destruir os negros como pessoas e como criadores e condutores de uma cultura própria. Infelizmente, "a fertilidade racionalizadora do racismo brasileiro não tem limites: é dinâmica, polifacética e capaz das manipulações mais surpreendentes” (Idem, p. 108).

Destarte, é imprescindível descolonizar esses orís hegemônicos e eurocêntricos; afinal, como bem nos ensina um orikí101, "nada se faz sem um bom orí" e "um bom orí é aquele que está sempre alerta, sempre sacrificando, sempre buscando evolução, sempre melhorando seu caráter e suas maneiras" (GBÁFÁOMI, 2020) - extirpar o epistemicídio, certamente, será um avanço. É preciso que o xaxará de Omolu continue limpando essa chaga social chamada racismo, pois, em se tratando de um (re)conhecimento dos cosmossentidos do candomblé,

na base da colonialidade cosmogônica está a divisão binária natural/social, apartando ancestralidade - espiritualidade da realidade material. Esse princípio do colonialismo arranca bruscamente o espiritual do social. A

101 Poesia com encantamento das forças ancestrais, louvação que ressalta desejos. relação milenar entre os biofísicos mundiais, os humanos e os espirituais incluindo os ancestrais, o sustento dos sistemas integrais de vida e mesmo da humanidade não são possíveis nesta colonialidade do poder (NOGUEIRA, 2020, p. 29).

Seja pelo compartilhamento de conhecimentos através de mais de uma linguagem (visual e oral) (KILEUY; OXAGUIÃ, 2009) utilizando metodologia própria para ensinar e aprender (MACHADO, 2013), seja pela permanente geração de valores éticos e comportamentais identitariamente negros (BRAGA, 1992), seja por ter desenvolvido e aperfeiçoado a sabedoria da negociação escrava (REIS; SILVA, 1989), seja por tornar-se um lócus de mobilização afropolítica contra o estrangulamento da sua condição humana (NASCIMENTO, 1978), o candomblé pode sulear uma formação antirracista.

Dessa maneira, essa religião brasileira de matriz africana pode contribuir para a implementação da lei 10.639/03, que tornou obrigatório o Ensino das Histórias e das Culturas Afro-Brasileira e Africana nas escolas brasileiras que ofertam a Educação básica e, em nível superior, do artigo 7ํㅡ do Parecer Normativo do Conselho Nacional de Educação 003/2004 conclamou a Educação das Relações Étnico-Raciais. Ao ser conhecida, compreendida e respeitada, ela trará mais "possibilidades de uma retomada histórica de consciência coletiva do agrupamento negro a partir dos espaços formais" (FLAUZINA, 2006, p. 107).

O candomblé é um movimento azeviche de resistência cultural, religiosa e política; portanto, é inadmissível que instituições formativas ainda perpetuem visões criminalizadoras, estereotipadas, discriminatórias, preconceituosas e racistas, desconsiderando a potência intelectual do legado ancestral do além-Atlântico que constitui(u) a brasilidade. Nas palavras de Flauzina (2006, p. 107),

as questões epistemológicas [...] fazem do ensino um local de reprodução e reconhecimento dos acontecimentos relacionados ao segmento branco e de estigmatização de todos os eventos e contribuições referentes à população negra. [...] A construção do passado é fundamental na afirmação de um sentido de coletividade, a forma como os conteúdos são apresentados nos livros didáticos brasileiros, desprovidos de um sentido de diversidade substantivo, não pode ser descartada enquanto fator que contribui para o distanciamento dos negros dos espaços formais de educação. 
Como a pluralidade de conhecimentos heterogêneos é agregacionista e oportuniza a participação de outros grupos sociais sem amordaçar suas culturas e saberes como aduzem Santos e Meneses (2010), devemos também trazer à baila nos mais distintos processos educativos a riqueza da diáspora do conhecimento na qual pulula a diversidade epistemológica. Assim, não caberá mais espaço para intolerâncias que impõem binarismo eurocêntrico e hegemônico, deslegitimando os negros como sujeitos cognoscentes.

À guisa de conclusão, insta salientar que, para Nogueira (2020, p. 65), "não há dúvidas de que o caminho tomado deve adotar a afrocentricidade", todavia não se trata meramente de substituir o eurocentrismo com fulcro no cumprimento da legislação educacional, mas reformular currículo também com cosmovisões de símbolos ritualísticos africanos e afro-brasileiros, letrar racialmente docentes e produzir e socializar material afrocentrado sem referenciais de despersonalização e aviltamento da população negra. Se Olódùmarè ${ }^{102}$ deixou conosco a sabedoria arbitral (GBÁFÁOMI, 2020), que optemos por conhecer, compreender e respeitar o legado de magnitude espiritual de "quem tem ideias e Orixás"103.

Epílogo

"Nígbàtí mo ti mò eni mo jé, ìdájó náà ajèjì mo nífeé sí rárá" “Enquanto eu souber quem sou, o julgamento dos outros não me

interessa"

(Provérbio iorubano)

O candomblé é uma religião brasileira de matriz africana que cultua seres encantados, como Orixás, Voduns e Inquices. Insubmissos à obrigatoriedade de conversão ao catolicismo, os negros ressemantizaram a ancestralidade espiritual do continente-mãe e criaram através dele uma estratégia de resistência cultural, religiosa e política ante o processo de subjugação imposto pelos colonizadores. Os seus adeptos e sacerdotes, desde os mercados seiscentista até a contemporaneidade, são alvos de ataques de racistas que desconhecem a sua engenhosidade.

Esse aniquilamento de nossas culturas e saberes configura-se em epistemicídio, já que desconsidera e/ou deslegitima em quaisquer espaços formativos a nossa tão 102 Também chamado de Olórun, significa Deus, o Onipotente.

103 Canção "Muito obrigado Axé”, de Carlinhos Brown. idiossincrática intelectualidade azeviche. Hodiernamente, ainda não são promovidas ações educacionais da Educação básica (Educação Infantil e Ensinos Fundamental e Médio) à Superior sem binarismo, estereotipias e hierarquizações, que efetivamente explicitem "o sentido de 'fazer cabeças' como alargamento para percepção do mundo como reaprendências" (MACHADO, 2013, p. 24).

Destarte, chega de destituir a nossa racionalidade! Basta de rechaçar nossas memórias existenciais! Urge descolonizar as supostas verdades universais tão propaladas por esses orís hegemônicos e eurocêntricos que demonizam o candomblé. É mister que possamos todas, todes e todos aprender a ler para ensinar ${ }^{104}$ conhecimentos negrorreferenciados aos nossos camaradas que possuem ou não na pele a cor da noite. Afinal, precisamos sulear, compreendendo, conhecendo, respeitando para quem sabe um dia valorizarmos nossas insurgentes epistemes afrorreligiosas. Àsè ${ }^{105}$ !!!

\section{Referências}

ALMA PRETA. Delegada nega denúncia de intolerância após homem vandalizar homenagem à mãe de santo em Salvador. Disponível em: https://almapreta.com/editorias/realidade/delegada-nega-denuncia-deintolerancia-apos-homem-vandalizar-homenagem-a-mae-de-santo-em-salvador. Acesso em: 10. ago. 2020.

A TARDE, Líder religioso acusa PMs de arrombamento e invasão no Curuzu, 2017. Disponível em: https:// atarde.uol.com.br/bahia/salvador/noticias/1886985-lider-religioso-acusa-pms-de-arrombamentoe-invasao-no-curuzu. Acesso em: 28 mai. 2020.

A TARDE, Monumento dedicado à Mãe Stella é alvo de vandalismo em Salvador, 2019. Disponível em: https://atarde.uol.com.br/bahia/salvador/noticias/2093460-monumento-dedicado-a-mae-stellae-alvo-de-vandalismo-em-salvador. Acesso em: 28 mai. 2020

BASTIDE, Roger. O Candomblé da Bahia: rito nagô. São Paulo: Companhia das Letras, 2001.

BENISTE, José. Dicionário Yorubá-Português. Bertrand Brasil, 2011.

BENITE, Anna M. C, SILVA, Juvan P., Gustavo A. A. Faustino e Benite, Claudio R. M. "Dai-Me Agô (Licença) Para falar de saberes tradicionais de Matrizes africanas no Ensino de Química". Quim. Nova, Vol. 42, No. 5, 570-579, 2019. Disponível em: https://www.scielo.br/scielo.php?script=sci arttext\&pid=S0100-40422019004500570. Acesso em: 22 abr. 2020.

BRAGA, Júlio. Candomblé: força e resistência. Revista Afro-Ásia. n. 15. p. 13-17. 1992.

BRASILDEFATO, Denúncias de intolerância religiosa aumentaram 56\% no Brasil em 2019, 2020 Disponível em: https://www.brasildefato.com.br/2020/01/21/denuncias-de-intolerancia-religiosaaumentaram-56-no-brasil-em-2019/. Acesso em: 28 mai. 2020.

CARNEIRO, Aparecida Sueli. A Construção do Outro como Não-Ser como fundamento do Ser. Tese Doutorado em Educação. Faculdade de Educação da Universidade de São Paulo (USP). São Paulo, p. Doutorado
339.2005.

104 Canção Yáyá Massemba.

105 Força vital. 
CORREIO NAGÔ, Após vandalismo, Busto de Mãe Gilda é restaurado em Salvador, 2016. Disponível em: https://correionago.com.br/portal/apos-vandalismo-busto-de-mae-gilda-e-restaurado-emsalvador/. Acesso em: 28 mai. 2020

FLAUZINA, Ana Luiza Pinheiro. Corpo negro caído no chão: o Sistema Penal e o Projeto Genocida do estado brasileiro. Brasília. 2006. 145 p. Dissertação (Mestrado em Direito) - Universidade Federal da Bahia, Salvador, Bahia.

G1 GLOBO, Ministério Público da Bahia instaura investigação para apurar intolerância religiosa após ataqueà Pedra de Xangô, 2019. Disponível em: https://g1.globo.com/ba/bahia/noticia/2019/01/04/ ministerio-publico-da-bahia-instaura-investigacao-para-apurar-intolerancia-religiosa-apos-ataquea-pedra-de-xango.ghtml. Acesso em: 28 mai. 2020.

G1 GLOBO, Busto de Mãe Gilda é alvo de vandalismo em Salvador; suspeito foi levado para delegacia, 2020. Disponível em:

https://g1.globo.com/ba/bahia/noticia/2020/07/15/busto-de-mae-gilda-e-alvo-de-vandalismo-emsalvador-suspeito-foi-levado-para-delegacia.ghtml. Acesso em: 10 ago. 2020

GBÁFÁOMI, Odé. Entendendo o Orí. Disponível em: https://ocandomble.com/2014/06/18/entendendoo-ori/. Acesso em: 09 nov. 2020

KILEUY, Odé; OXAGUIÃ, Vera de. 0 candomblé bem explicado - Nações Bantu, Iorubá e Fon. Rio de Janeiro, Pallas, 2009.

LITERAFRO, Mãe Stella de Oxóssi, 2019. Disponível em: http://www.letras.ufmg.br/literafro/ autoras/299-mae-stella-de-oxossi. Acesso em: 28 mai. 2020

MACHADO, Vanda. Pele da cor da noite. Salvador: EDUFBA, 2013

NASCIMENTO, Alessandra Amaral Soares. Candomblé e Umbanda: Práticas religiosas da identidade negra no Brasil. RBSE - Revista Brasileira de Sociologia da Emoção. Ano 9, v. 27, p. 923-944, 2010 Disponível em: http://www.cchla.ufpb.br/grem/AlessandraArt.pdf. Acesso em: 23 abr. 2020.

NASCIMENTO, Abdias do. 0 genocídio do negro brasileiro - Processo de um racismo mascarado, Editora Paz e Terra, 1978.

NOGUEIRA, Sidnei. Intolerância religiosa. São Paulo, Pólen, 2020.

PRANDI, Reginaldo. "O Candomblé e o Tempo - Concepções de tempo, saber e autoridade da África para as religiões afro-brasileiras", p. 44. Revista Brasileira de Ciências Sociais - Vol. 16 no. 47, 2001 Disponível em: http://www.scielo.br/pdf/rbcsoc/v16n47/7719.pdf. Acesso em: 23 abr. 2020.

REIS, João José; SILVA, Eduardo. Negociação e Conflito - a Resistência negra no Brasil escravista. São Paulo: Companhia das Letras, 1989

SANTOS, Boaventura de Sousa; MENESES, Maria Paula (Orgs.). Epistemologias do Sul. São Paulo: Cortez, 2010

SILVA, Maria Alice Pereira da. "Pedra de Xangô: um lugar sagrado afro-brasileiro na cidade de Salvador". 405 f. Dissertaç̃̃o (Mestrado em Arquitetura e Urbanismo). Faculdade de Arquitetura e Urbanismo. Universidade Federal da Bahia, 2017 .

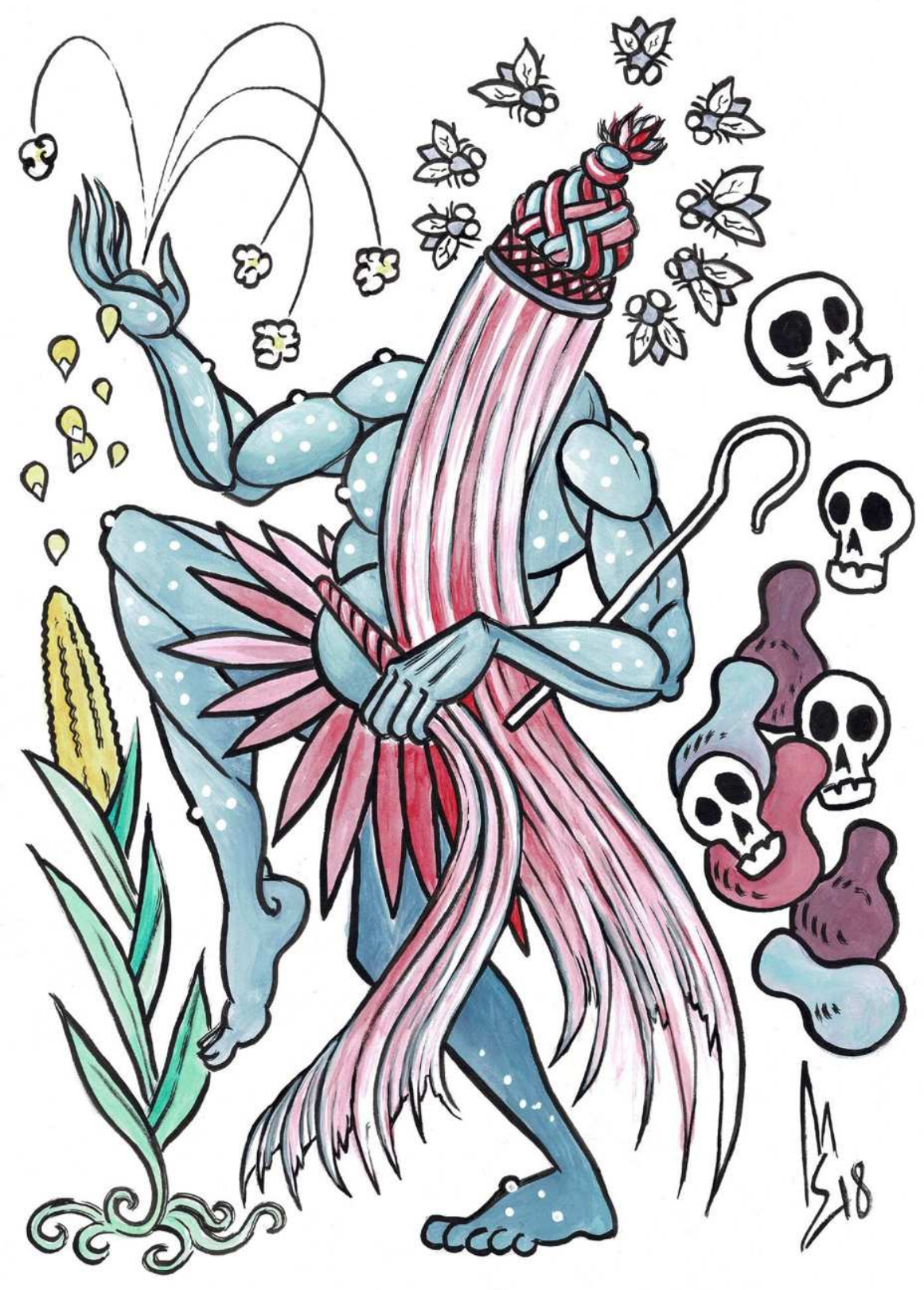




\section{CLINICAR NA TRANSITIVIDADE: INSURGÊNCIAS AMEFRICANAS DESCALCAS COMO RELATOS DE EXPERIÊNCIAS DESDE GESTOS - POÉTICAS E POLITICAS}

Ademiel de Sant'Anna Junior

\section{Sànpònná - Obàlúaỉyé106}

ENTORNAR-ME

Aquele que tem a função de equilibrar o ciclo vital. Promove o mistério da morte e do renascimento.

Sànpọ̀ná - Obàlúaiyé, cuida das doenças epidêmicas,

é o único que tem o poder de suprimi-las.

$$
\text { Òrìsà da Terra! }
$$

Está vinculado a uma concepção geológica da existência da Terra, sua composição, estrutura, propriedades físicas, camadas geológicas,

$$
\text { história. }
$$

Àse preto, vermelho e branco.

Lidera o poder dos ancestrais,

princípio genitor masculino

associado aos Òrìsà Funfun

e à estrutura ambiental - troncos e ramos de árvore.

No sistema oracular divinatório,

tem a função de trazer à tona

o projeto mítico social das pessoas

e sua relação com a comunidade.

Ebora de poder extraordinário relacionado a Ikú.

Sàșàrà, espíritos ancestrais.

Sànpọná - Obàlúaiyé - o poder misterioso.

106 Oríkì (louvação) para Șànpọ̀ná - Ọbàlúaiyé, construído a partir das obras: "Agadá: dinâmica da civilização africano-brasileira”, de Marco Aurélio Luz (2000): "Os Nàgô e a Morte: Pàde, Àsè̀è e o culto Égun na Bahia", de Juana Elbein dos Santos (2012); e “Dicionário yorubá-português", de José Beniste (2011).
Roda gira, gira roda no siré

Àgò

Onde os dedos mais importantes são dos pé Marca tempo pulsa roda circula Àșe

É descalço que a cabeça vai gira

É no chão que encontro ònìs̀̀

Meu sustento é cajado

Minha arma o espelho Inteligência é pilão ogó é desejo

Roda gira, gira roda no siré

É história em contação

É partícula em ação

É partilha em expansão

Roda gira, gira roda no siré (Ademiel de Sant'Anna Junior)

Àgò

Hoje gostaria de partilhar histórias... Não aquelas do "era uma vez", mas histórias por onde cantam muitas vozes que transpassam estes e outros tempos. Sabe aquele arrepio que vem e que circula enquanto sacode o corpo por vibrações que não sabemos explicar? Tudo bem não explicar. Na "desexplicação" das coisas, 
conforme nos contaram, circula o àșe $\mathrm{e}^{107}$ deste capítulo. Escorrem ainda por aqui desdobramentos práticos que dão expressão também ao meu projeto de dissertação de mestrado. São "exercícios de atrevivência" em andamento no PPGPSI ${ }^{108}$.

No começo, àgò, "ancestralidade do tempo no espaço, dito de pés descalços corre e escorre da boca [...] é fala no corpo além mais, mais reverência que pedido de licença" (SANTIAGO, 2020, p. 13), peço passagem saudando a ancestralidade que incorpora quem lê, quem escreve e quem transita nas dimensões sensíveis da oralidade, convocados aqui desde ìtàn ${ }^{109}$ e oríkì ${ }^{110}$.

Tentaremos neste relato, que é de experiências de fazeres e sentires como aposta clínica, produzir deslocamentos nesta prática: Seja na definição formal da língua, onde clínica limita o corpo à "instrução médica feita por um especialista em um hospital, ao lado da cama de pacientes que servem de objeto de estudo" (MICHAELIS, 2019), ou seja ainda pela gramática em ato, que define a ação de clinicar a partir da intransitividade do verbo, sem precisar de complementos para ser entendido, encerrando-se em si. Tomando esta dimensão gramatical intransitiva como problemática, e lembrando, com Grada Kilomba (2019, p.14) "que a língua, por mais poética que possa ser, tem também uma dimensão política de criar, fixar e perpetuar relações de poder e de violência, pois cada palavra que usamos define o lugar de uma identidade". Como produzir estratégias para um clinicar que opere na potência da transitividade do verbo que insurja da gramática para compor fazeres inventivos, do verbo transitivo, senti(n)do com o corpo?

Olhe pros lados enquanto percorre estas linhas, não é eu ou tu... Somos nós que estamos aqui, em cada pronome ou verbo, em cada verso deste oríkì. Invoco Lélia Gonzalez (RIOS; LIMA, 2020), que nos provoca amefricanidade, ampliando nossos corpos para além de quaisquer limitações territoriais, linguísticas e ideológicas impostas pela colonização branca do continente americano: hão de escorrer gestos que constituem nossas parecenças nos diferentes territórios da diáspora. Somos descendências vivas de africanas e africanos, sequestradas pelo tráfico negreiro, mas 107 Ao escrever palavras em yorùbá, tomamos como ato insubmisso a não utilização do itálico. Yorùbá é língua que vive no/do corpo, composição ancestral que aqui ginga pela oralidade, Âșe - força vital, poder de realização, conforme Juana Elbein dos Santos (2012).

108 Programa de Pós Graduação em Psicologia Social Institucional - Universidade Federal do Rio Grande do Sul.

109 Conforme Beniste (2011, p. 403), corresponde aos mitos, histórias. İtàn ìgbesi ayé significa biografia; ìtán Id́ílé significa história de família.

110 "Título, nome, louvacão que ressalta fatos de uma sociedade, de uma família ou de uma pessoa e igualmente seus desejos [...]", conforme nos aponta Beniste (2011, p. 591). também daquelas e daqueles que aqui chegaram antes de Cabral ou Colombo (RIOS LIMA, 2020). E nestas experiências que encruzilham bantus, yorùbá, ewe-fon ${ }^{111}$, e tantas outras experimentações e organizações de vida que resistem aos apagamentos coloniais, sustentam-se sussurros ao pé do ouvido, vibrando nossas moléculas, enunciando a inseparabilidade entre corpo, matéria e espírito, não sendo possível clinicar como verbo intransitivo. Neste processo de transitividades falamos a partir da concepção de mundo yorùbá, e diferente da lógica binária cristã ocidental que condiciona ao céu ou ao inferno o espírito que deixa o corpo físico, falamos aqui das possibilidades de coexistência entre ọ̀run-àiyé (MELO, 2019) que organizam transversalmente os mundos do que é visivel, àiyé, do que é sensível, ọ̀run, por onde cirandam òrìșàs, irúnmalẹ̀, ará-ọ̀run e egúngún. Mundos em composição, onde além de coexistir incorporam movimentações. Ritmos da ancestralidade por onde não conhecemos separação. Corpo, espírito, gestos poéticas e políticas seguem em articulação. Lindas danças coletivas, cantos e cantigas singulares. Nesta composição nos tornamos movimento, guiados pela ancestralidade que se afirma na presença, do presente na memória, que guardada por nossas mais velhas se complementam pela transitividade do verbo ancestral - Roda gira, gira roda no siré ambas temperadas com azeite de dendê.

Siré Òrìsà

Siré é diálogo entre ọ̀run e àiyé, é música invocação, é dança convocação, é soma multiplicação de corpo em corpos, de um caminho em territórios, de indivíduos em coletivos e de todos estes em: corpus oròliterário que contam ìtàn que cantam oríkì poesias ancestrais que convocam devir. Neste siré òrìsà encanto de palavra e som, de ruídos e vibração, desde as terreiras buscamos àșe como mais importante força de expressão para a vida. Pois é no siré desde sua preparação, que invocamos com articulação, conforme nos aponta Tatiana Maria Damasceno:

111 Com a violência do tráfico negreiro, foram amputados para o Brasil grupos africanos organizados em diferentes troncos linguísticos. Ressaltamos aqueles originários das regiões bantos constituídos por mais de 300 línguas diferentes. Enfatizamos também os Yorùbá localizados ao sudoeste da Nigéria ewe, gun, fon, mahi) muito parecidas e faladas em territórios de Gana, Togo e Benim, conforme nos aponta Castro (2005). 
Se processando através da interação entre vários elementos: o canto, a dança, a palavra, o som, a música, o público, os adeptos e a comida. Essa relação, entre meios materiais e simbólicos, cria a correlação dinâmica necessária para a transmissão do axé (DAMASCENO, 2010, p. 3).

Muito embora um siré signifique a própria atmosfera da festa de celebração aos òrị̀àa, chamamos a atenção para o modo de organização dos ritmos e sequência dos oríkì. A vibração dos tambores e a invocação pela palavra cantada no coletivo transmutam corpos em portais que, transbordados pela presença do òrìșà, fazem circular pelos gestos a força vital que fortalece a vida, e a esta energia chamamos àșe. É preciso nomear para que chegue òrị̀à, é preciso expandir os territórios do corpo para que em seu ouvido a entidade possa falar.

Num siré, quem abre os caminhos é Éșù, òrìsà a quem se convoca primeiro. Éșù é o próprio caminho, comunicação e linguagem. Tanto na abertura dos trabalhos quanto no processo de saboreio das palavras (EVARISTO, 2008), nada se faz sem Éṣù òrị̀à mensageiro entre o visível e o invisível, dono da palavra, benevolente quando tratado com consideração. Maria de Lourdes Siqueira (1995) nos lembra de que se trata de òrìsà brincalhão, mas que ninguém se engane, Éṣù desacomoda os caminhos com astucia, e transmite as respostas do ọ̀run, nos ensinando a olhar de perto para língua, enquanto devolve a palavra, inventando enquanto verseja modos de emancipar a vida.

Ser e estar na primeira pessoa é o que constitui nossa relação com Éșù, e nesta relação repleta de tensionamentos e indeterminações de percursos Éșù expande vida entre a escrita do corpo que conta e as inscrições dos corpos que escutam e canta o corpo, gesto que propõe composições que lutam. Éșu é mensageiro que abre os caminhos e os discursos, que carrega em versos os gestos do transcurso.

Enquanto conto Éṣù, posso escutar Neuza Santos Souza (1983) que, no livro "Tornar-se Negro", nos presenteia com experiências na clínica psicanalítica, evidenciando, que a condição para a construção de autonomia se dá exercendo um discurso sobre si mesmo. Para a autora, saber-se sujeito negro no mundo "sobretudo é comprometer-se a resgatar a sua história e recriar as suas potencialidades" (SOUZA, 1983, p.18). Éșù coloca-se à frente nesta experimentação de tornar-se negro, como um exercício de criar a si na linguagem para além das intransitividades, ou seja, é importante contar quem somos para retornarmos ao que podemos vir a ser.
Contando quem soul

Meu nome? Ademiel de Sant'Anna Júnior, filho de Geni Silva de Sant'Anna e Ademiel de Sant'Anna, neto de Francisca da Silva, vó Chica. Poeta e músico, psicólogo de formação, tenho me atrevido por estas travessias que partilho por aqui. Por muito tempo acreditei que não podia falar, minha voz, assim como minha coluna foram se curvando, falava baixo, sentia-me inadequado, me percebia intruso em mundos onde minha imagem era estranhada nas posições que ousava ocupar. Lembro-me de tomar contato, em 2019, com o livro de bell hooks, "Olhares Negros: Raça e Representação". Pulsava forte por cada linha, doía muito enquanto me expandia:

Para pessoas negras a dor de não poder controlar as nossas imagens como nos vemos (Se nossas visões não forem descolonizadas) ou como somos vistos, é tão intensa que isso nos estraçalha. Isso destrói arrebenta nossas costuras de nossos esforços de construir o ser, de nos reconhecer (hooks, 2019, p. 35).

Cada célula que vibrava, se contorcia e desdobrava conforme se alargavam minhas fronteiras que aqui chamarei oròliterárias. Orò é um dos momentos mais importantes na circulação do àșe (GODOI, 2020), correspondendo a um conjunto de condições rituais do processo de iniciação que cada òrìșà tem em específico. Suas sacralizações, folhas, cantigas e quizilas, cada segredo partilhado, cada aprendência que expande o àșẹ. É no orò que tomamos contato com a literalidade da experiência, no e do corpo. A pulsação intensiva de cânticos e batuques faz a invocação de òrìșà, que diretamente do ọ̀run grafa literalidades no àiyé. Iniciar-me nos encontros com as epistemologias pretas não significou chegar, mas retornar, entornar-me, tornar-me.

A disciplina ofertada pelo PPGPSI-UFRGS, no primeiro semestre de 2019, e intitulada: “Clínica Política Antirracista" me ensinou com as mais velhas que naquele siré se encontravam, a escurecer. Aprendências oròliterárias do corpo se dão neste encontro de (re)significados das vivências. No primeiro dia de aula, sala cheia, olhares negros se cruzam no primeiro encontro, falamos de expectativas, sentados em roda com olùkón ${ }^{112}$ cujo orúkọ Ọbà Olórí-Ọba ${ }^{113}$ inscreve afetos e propõe tratativas, do escuro escreve uma carta de versejadas coletivas, nos lê, convoca atrevimentos 112 Professora, conforme nos demonstra Beniste (2011).

113 Segundo Beniste (2011) orúko é nome próprio em yorubá, composto por diversas palavras que reino, a primeira esposa do rei, a rainh. 
Iniciamos então nossos encontros nomeando para tratar, não mais irão nos calar se realizavam potências é siré òrìșà! Enquanto epistemicídios funcionam como operadores do dispositivo colonial de racialidade produzindo a fragmentação e o destroçamento de quaisquer pensamentos não brancos, a fim de consolidar a supremacia intelectual branca, conforme nos aponta Sueli Carneiro (2005, p.10):

É através desse operador que este dispositivo realiza as estratégias de inferiorização intelectual do negro ou sua anulação enquanto sujeito de conhecimento, ou seja, formas de sequestro, rebaixamento ou assassinato da razão. Ao mesmo tempo, e por outro lado, o faz enquanto consolida a supremacia intelectual da racialidade branca.

Trata-se de um processo articulado pelo racismo oriundo de empreendimentos coloniais, onde além de se estabelecer o monopólio do conhecimento pela subalternização intelectual do corpo negro, produz-se o seu silenciamento. Grada Kilomba (2019) vai recordar do aparato tecnológico do colonialismo chamado, máscara de silenciamento, instrumento amplamente utilizado como tecnologia sádica de tortura contra as sujeitas e os sujeitos escravizados para evitar que comessem do que plantavam, anexando ao corpo negro violentado o senso de mudez e de medo. Grada Kilomba (2019) nos faz compreender que a máscara representa o colonialismo, a partir de suas políticas sádicas de conquista e dominação. Nesta disciplina/ vivência pude problematizar o monopólio da produção de conhecimento, a partir de cinco países que compõem o norte global e sustentam as formações universitárias (GROSFOGEL, 2016). Mas também pude nomear minhas potências, deslocando-me da pergunta “Quem pode falar?”, para a afirmação “Eu vou falar!”. bell hooks (2019) vai materializando a necessidade de que nossos movimentos estejam encharcados de comprometimento com as transformações das imagens que a supremacia branca construiu, e vai atualizando a partir das tecnologias da colonialidade sobre nós, em outras imagens, de nós sobre nós. É preciso criar alternativas, abrindo espaço com o nosso posicionamento de vida, para imagens transgressoras:
Para encarar estas feridas, para curá-las as pessoas negras progressistas e nossos aliados nesta luta devem estar comprometidos em realizar os esforços de intervir criticamente no mundo das imagens e transformá-lo conferindo uma posição de destaque em nossos movimentos políticos de libertação e autodefinição (hooks, 2019, p.36).

E nestas imagens transgressoras fui construindo outros modos de lidar com os espaços que ocupava, impreterivelmente percebi a urgência de romper com alguns territórios para nascer pro òrị̀à. Habitar espaços onde meus gestos pudessem se expandir me fez, e me faz, vibrar por estradas que vou construindo com as solas dos pés em contato com a terra, na pulsação de cada passo do orò àròsọ èkộ ${ }^{114}$ que gira roda no siré, marca tempo, pulsa roda, circula àșẹ, fazendo do corpo portal, desde a literatura preta para re-existência gestual.

Da coreografia ao gesto, a potência Oríkì

0 gesto trata da movimentação que escapa do corpo, diferentes das coreografias, gestos são invocações insurgentes encharcadas, ou não, de intencionalidades; gestos são persistências poéticas do corpo que extrapolam e escorrem como resistência que não sabíamos que estavam ali. Mecanismos de luta e autodefinições do corpo negro, que vão dançando no fronte. É desde os gestos que contamos nossas histórias, compartilhamos nossas lutas coletivas, criamos imagens transgressoras e potencializamos nossas ações escurecedoras nos espaços que ocupamos. Somos presenças fluidas que insurgem mesmo com tantas equações desiguais (CESAIRÉ, 1978) nos sobrepondo para além das estruturas coloniais. Ou seja, parafraseando Fanon (2008), carregamos conosco a responsabilidade de afirmar a cultura, suportando o peso de uma civilização que já existia antes dos horrores da escravização, e que persiste existindo; somos nossas histórias do futuro, do passado e do presente nas afrografias da memória, conforme postula Leda Martins (1997) sobre suas vivências no congado ${ }^{115}$. A autora nos chama a atenção para gestos que grafam desde o corpo, performances da oralidade que transpassam narração e/ou

114 "Ritual da produção literária", tradução livre de Daniel Abídèmí Adẹ́báyọ Majaro, nigeriano naturalizado brasileiro, palestrante no curso de língua e cultura Yorùbá - Ėtò Èkó Édè Ati Aasà Yorùbá, promovi-

do pelo Núcleo de Estudos e Pesquisa É'LÉÉKO em 2020 .
115 Trata-se de manifestação cultural resultante da interação entre a cultura africana, indígena e luso-espanhola encruzilhadas em solo brasileiro, conforme nos aponta Jarbas Siqueira Ramos (2017). 
a descrição, para a dimensão do que escorre nos movimentos de contar, cantar e vivenciar no relevo da pele a ancestralidade que verseja uma história (MARTINS, 2003). E destas afrografias da memória vocalizam-se grafias que invocam toda a diversidade de África, persistentes nas diásporas transmitidas aos nossos corpos:

A África, em toda sua diversidade, imprime seus arabescos e estilos sobre os apagamentos incompletos resultantes das diásporas, inscrevendo-se nos palimpsestos, que por inúmeros processos de cognição, asserção e metamorfose, formal e conceitual, transcriam e performam suas presenças nas Américas. As artes e os constructos culturais matizados pelos saberes africanos, ostensivamente nos revelam engenhosos e árduos meios de sobrevivência destes vestígios, durante os séculos de sistemática repressão social e cultural da memória africana [...] (MARTINS, 2002, p.67).

Não conseguiram nos apagar, já que o gesto é política do vestígio. Vamos performando nossas presenças, produzindo o mundo enquanto nos experimentamos nestas espirais de interações. Vou por aqui aprendendo sobre viver desde o mais velho ao mais novo, convocando aqui no instante a potência oríkì como modo poético de expressão dos sentires, fazeres e memórias. 0 oríkì transcreve-se como manifestação da tradição oral africana ricamente representada na sociedade yorùbá (IDRISSOU, 2020). Oríkì é invocação poética, musical, manifestação de vestígios atemporal, nomeação de atributos de òrìsà femininos e masculinos, da natureza e dos animais. É poesia memorial, que se transcreve na tradição oral. Os oríkì contam nossas histórias, fluindo vestígios e redesenhando territórios em transitividade, desde afrografias da memória. Quando recitamos um oríkì invocamos no corpo a transitividade òrìsà que nos ajuda a transfigurar enquanto nos deslocamos por outros modos de operar. Leda Martins nos adverte que "É no corpo mesmo da escrita que este outro Brasil se performa e se instala, e que a arte se quer também como ofício de transfiguração, de rearranjo da memória e da história." (MARTINS 2012, p.220). Roda gira, gira roda no siré é história em contação é produção oròliterária em movimentação.

\section{Orò Àròso Ềkó}

Retornando pelas águas do grande mar, ao continente africano, podemos observar na geografia das pessoas yorùbá, enunciados da inseparabilidade entre poesia, experiência e emissão, desde as vivências com o corpo no mundo e as suas (re)flexões acerca do mundo (JEJEDE, 1997). No oríkì, sentimento e pensamento se entrelaçam coletivamente e dialogicamente enquanto são recitados, ou seja, composição, transmissão e performance ocupam importante espaço, transpassando os limites constituídos. Não é do mau hálito desonesto do colonizador que cantamos nossas histórias, não será da esqualidez de sua pele e expressões que constituímos os fazeres pela clínica. A proposta é escura, como aposta clínica gesto-poéticapolítica. Não nos constituímos desde a técnica das "faces esquálidas", ao contrário vou interrogando a composição de corpos que se contam neste exercício do instante. Na hibridez das histórias entrecruzadas e forças agravadas no versejar da língua, orò àròso è̀kó tem se apresentado como ato político, transitivando o clinicar. Antônio Risério (1996) articula que nasce o oríkì de certo jogo que se costura entre tramas verbais que se enramam na cultura yorùbá fazendo:

A expansão de uma célula verbal é fenômeno comum no mundo dos textos. Jolles fala de provérbios que se expandem até se converterem em longos poemas proverbiais. Coisa semelhante se passaria entre o oriki-nome o oriki-poema, com o nome atributivo se expandindo verbalmente em direção ideal à constituição de um corpo sígnico claramente percebido e definido como "poético". [...] Na verdade, a expressão "oriki" designa nomes, epítetos, poemas. Cobre portanto de uma ponta a outra o espectro da criação oral em plano poético (RISÉRIO, 1996, p.35).

A escuta, nesta clínica transitiva, é aposta na criação de novas células verbais, é na palavra que expandimos e fazemos revoluções. E nesta encruzilhada, apostar na invenção de palavras tem me ensinado a transbordar pelas histórias em contação, pelas partículas em ação e pelas partilhas em expansão.

Yèyé Olomi Tútù̀ 116

Nestas partilhas, convoco aqui a correspondência com minha mãe, Geni Silva de Sant'Anna, que me ensinou a cantar para contar histórias, me ensinou a ler partituras para depois romper com elas, enganá-las com vocalizes, contracantos e tantas outras estratégias e memórias que viram pelo avesso o compasso da notação

116 “Graciosa mãe, senhora das águas frescas", parte do oríkì de mamãe òsùn. 
musical. Cantar tem tratado minhas feridas. Quem nunca foi tocado quando escuta ou canta uma música?

Cabe aqui então nomear, nesta experiência oròliterária, além do rompimento com as partituras e coreografias, a aposta na não fixação em uma metodologia. Vou afirmando então, a partir de gestos metodológicos, a proposta por operações transitivas pela clínica, enunciando como intercessora a oralitura, como ponto de saída que é retorno, onde o coletivo é um dos caminhos para a constituição deste contorno:

Palavra poética, cantada e vocalizada, ressoa como efeito de uma linguagem performática do corpo, inscrevendo o sujeito emissor, que a porta, e o receptor, a quem também circunscreve, em um determinado circuito de expressão, potência e poder (MARTINS, 2007, p. 26).

Tenho experimentado na clínica e na pesquisa, olhar de perto para língua, pensando modos de circular enquanto se brinca pelo cantar da palavra. Resistências sociais e culturais, que se ativam na memória do corpo negro, operam pela oralidade experiências desde ancestralidade.

Não é tarefa fácil estar em primeira pessoa, entretanto, não estou só, meu corpo é coletivo, é transitivo e gesto, aposta nascente que luta e resiste. Não me interessa então cantar/dançar/escrever conforme a música. 0 meu desejo é gritar, gritar tão alto que possamos de algum modo romper com as barreiras deste tempo greco-romano guardado por Chronos que tenta contar esta ficção de uma existência sincrônica de um passado, um presente e um futuro. Apenas este tempo não me serve, e nesta experiência não servil vou me conectando com as espirais do tempo (MARTINS, 2002), que vão fazer torções desde as posições cronológicas do tempo:

A percepção cósmica e filosófica entrelaça, no mesmo circuito de significância, o tempo, a ancestralidade e a morte. A primazia do movimento ancestral, fonte de inspiração, matiza as curvas de uma temporalidade espiralada, na qual os eventos, desvestidos de uma cronologia linear, estão em processo de uma perene transformação. Nascimento, maturação e morte tornam-se, pois, contingencias naturais, necessárias na dinâmica mutacional e regenerativa de todos os ciclos vitais e existenciais. Nas espirais do tempo, tudo vai e tudo volta (MARTINS, 2002, p. 82).
Nossa língua deriva da ancestralidade amefricana, desde Lélia Gonzalez (RIOS; LIMA, 2020), em uma conexão aureada por diversos segredos que debocham, dão gargalhadas astuciosas enquanto dançam nossos corpos ancestrais ludibriando aqueles que nos oprimem. Escorremos como águas por entre dedos que tentam nos capturar.

Enxergar, escutar, tatear.... Esta ciranda, de aprendências e sentidos tem me feito interrogar, então: E se ao invés de só olhar, puder me atrever a enxergar no escuro? E se ao invés de só ouvir, puder me atrever a escutar cantos e pulsações? E se ao invés de só tocar e/ou pegar, puder me atrever a tatear? E se ao invés de só engolir ou cuspir, puder me atrever a saborear enquanto conheço novos gostos? Não deveriam ser estas as expressões da clínica e da pesquisa?

Asseverando nestas experimentações me encontro com Conceição Evaristo, pelas escrevivências, que prodigaliza a escrita no escuro (EVARISTO, 2008) como modo de me atrever pela linguagem sentida, e não convencionalmente assumir a função reprodutiva dos modos gramaticais que operam na língua, conforme Ponciá Vicêncio nos enuncia:

Da leitura era preciso tirar outra sabedoria. Era preciso autorizar o texto da própria vida, assim como era preciso ajudar construir a história dos seus. E que era preciso continuar decifrando nos vestígios do tempo os sentidos de tudo que ficara para trás. E perceber que por baixo da assinatura do próprio punho, outras letras e marcas havia. A vida era um tempo misturado do antes-agora-depois-e-do-depois-ainda. A vida era mistura de todos e de tudo. Dos que foram, dos que estavam sendo e dos que viriam a ser (EVARISTO, 2017, p.110).

Este será o vocalize que escapa neste capítulo descompassado de um texto acadêmico, escorrendo linhas gesto, oríkì que vão se afirmando pela hibridez das travessias dos que foram antes, dos que são agora e dos que virão. Pelos ritmos dos vocalizes experimentamos torções, nascimentos, crescimentos e criações.

Dábá Aláyè ${ }^{117}$ - Atrevivência

Neste oríkì de cantar e contar no escuro sustentado no cajado de Òrísálá faço um convite a experimentações que encruzilhem terreiras, músicas, poemas

117 Dábá - aventurar, movimentar atrever e Aláyè - Vivo, permeável a vivências (BENISTE, 2011). 
rodas de samba, e tantos outros sentires nutridos da inseparabilidade da política que é gesto - poesia e clínica. Cantar afrografias da memória tem tratado de conectar este versejar desde dentro realçado por Juana Elbein dos Santos (2002) como experimentação para além do simples registro do que se vê. Nesta aposta desde dentro expandimos enquanto reinterpretamos produzindo encontros inventivos na diáspora. Se deslocar desde dentro tem sido meu objetivo ao longo deste relato de experimentação e ainda em meus escritos da dissertação. Desde dentro tenho cantado de minha janela um oríkì que escapa pelas frestas e encontra no espaço mais vozes que produzem ressonância, vibração e sentido.

Nestes gestos, a aposta é clinicar na transitividade dede dentro do verboverso enunciando-a como epistemologia negra. A condição da existência é a impreterível presença. Mesmo quando genocidas eleitos, aliados a uma pandemia tentam nossos corpos exterminar atrevo-me a cantar forte de minha janela. Esta é minha forma de lutar desde dentro. E se você cantar da sua? Se for preciso, grite sua voz! Não importa a letra, cante! Vamos fazer nossas vozes vibrarem melódicas, produzindo tantas torções nos compassos que a violência de suas vibrações vai confundir Chronos e rasgar as lixas que, ardilosamente, insiste a branquitude em esfregar para manter nossas feridas abertas e sangrando. Escrevo aqui com minhas irmãs pretas e irmãos pretos e pretes, estejam onde estiverem na diáspora, dentro de quaisquer movimentos e políticas pela vida. Mais velhos e mais novos, que cirandam neste tempo e em outros tempos, sem divisões vocais. Cante, como e por onde conseguir cantar, do fronte, das janelas que se abrem, não deixe sua voz paralisar. Cante de onde estiver e como puder, saiba, quando você canta, vibramos nós: Poetas, Artesãos, Rainhas, Reis, Agricultores, Guerreiras e Sacerdotes são todas estas posições e tantas outras que ainda virão como experimentações, nesta aposta de se inclin(ic)ar pelo gesto. Atrevo-me aqui, com toda honestidade de quem escorre riscos Dábá Aláyè - Atrevivência.

\section{Referências}

BENISTE, José. Dicionário yorubá-português. Rio de Janeiro: Bertrand, 2011.

CARNEIRO, Aparecida Sueli. A construção do outro como não-ser como fundamento do ser. 2005. $339 \mathrm{f}$ Tese (Doutorado em Educação) - Programa de Pós-Graduação em Educação. Faculdade de Educação, Universidade de São Paulo, São Paulo, 2005
CASTRO, Yeda Pessoa. A influência das línguas africanas no português brasileiro. In: Secretaria Municipal de Educação - Prefeitura da Cidade de Salvador (org.). Salvador: Secretaria Municipal de Educação, 2005.

CESAIRÉ, Aimé. Discurso sobre o colonialismo. Lisboa: Sá da Costa, 1978.

DAMASCENO, Tatiana Maria. Xirê: uma performance corporal de restauração de energia vital. In CONGRESSO DE PESQUISA E PÓS-GRADUAÇ̃̃̃O EM ARTES CÊNICAS, 6., 2010, São Paulo. Anais [...] São Paulo: ABRACE, 2010. p.1-6.

EVARISTO, Conceição. Insubmissas lágrimas de mulheres. 2. ed. Rio de Janeiro: Malê, 2016.

EVARISTO, Conceiç̃ão. Poemas da recordação e outros movimentos. Belo Horizonte: Nandyala, 2008.

EVARISTO, Conceição. Ponciá Vicêncio. Rio de Janeiro: Pallas, 2017.

FANON, Frantz. Pele negra, máscaras brancas. Salvador: EDFBA, 2008.

GODOI Jéssica Caroline Processos educativos em um terreiro de candomblé de Uberaba, MG 2020 150 Dissertação (Mestrado em Educação) - Programa de Pós Graduação em Educação, Universidade Federal de Santa Catarina, Florianópolis, 2020.

GROSFOGUEL, Ramón. A estrutura do conhecimento nas universidades ocidentalizadas: racismo/sexismo epistêmico e os quatro genocídios/epistemicídios do longo século XVI. Sociedade e Estado, Brasília, v. 31, n. 1, p. 25-49, Apr. 2016

hooks, bell. Olhares negros: raça e representação. São Paulo: Elefante, 2019.

IDRISSOU, Alex Kevin Ouessou. Oríkì Yorùbá: uma arte verbal africana na América Latina - expressões brasileiras. 2020. 92 f. Dissertação (Mestrado em Literatura Comparada) - Programa de Pós-Graduação em Literatura Comparada, Universidade Federal da Integração Latino-Americana, Foz do Iguaçu, 2020.

JEJEDE, Olutoyin. Bimpe. A poesia laudatória e a sociedade nigeriana: a Oriki entre os Yoruba. Revista Crítica de Ciências Sociais, Coimbra, n. 47, p. 75-98, fev. 1997.

KILOMBA, Grada. Memórias da plantação: episódios de racismo cotidiano. Tradução Jess Oliveira. Rio de Janeiro: Cobogó, 2019

MARTINS, Leda Maria. Afrografias da memória. São Paulo/Belo Horizonte: Perspectiva/ Mazza Edições, 1997.

MARTINS, Leda Maria. A fina lâmina da palavra. O Eixo e a Roda: Revista de Literatura Brasileira, Belo Horizonte, v. 15, p. 55-84, dez. 2007.

MARTINS, Leda Maria. Arabescos do corpo feminino. In: ASSIS, Eduardo; BEZERRA, Kátia da Costa DUARTE, Constância Lima (Orgs.). Gênero e representação na literatura brasileira: ensaios. Belo Horizonte p. 219-228: UFMG, 2012.

MARTINS, Leda Maria. Performances da oralitura: corpo, lugar da memória. Letras, n.26, p.63-81, 2003.

MARTINS, Leda Maria. Performances do tempo e da memória: os congados. 0 Percevejo - Revista de Teatro, Crítica e Estética, Rio de Janeiro, ano 11, n. 12, p. 68-83, 2003.

MELO, Emerson Costa. Òrun-Àiyé - o "sagrado vivido" pelos membros do candomblé e a afroterritorialidade: diálogos entorno de um campo de possibilidades. REVES - Revista Relações Sociais, [S. l.], v. 2, n. 3, p.477-49, 2019

MICHAELIS. Moderno dicionário da língua portuguesa. São Paulo: Melhoramentos, s.d. Disponível em: https://michaelis.uol.com.br/moderno-portugues/busca/portugues-brasileiro/download. Acesso em: 22 abr. 2014

RAMOS, Jarbas Siqueira 0 corpo do congadeiro como corpo-encruzilhada: um olhar sobre performatividade congadeira. Revista Rascunhos - Caminhos da Pesquisa em Artes Cênicas, 
Uberlândia, v. 4, n. 3, p. 82-97, 15 set. 2017.

RAMOS, Jarbas Siqueira. 0 Corpo-encruzilhada como experiência performativa no ritual congadeiro. Rev Bras. Estud. Presença, Porto Alegre, v. 7, n. 2, p. 296-315, ago. 2017 . Disponivel em: http://www. scielo.br/scielo.php?script=sci_arttext\&pid=S2237-26602017000200296\&lng=pt\&nrm=iso. Acesso em: 18 jan. 2021. https://doi.org/10.1590/2237-266066605.

RIOS, Flávia; LIMA, Márcia (Orgs.). Lélia Gonzalez. Por um feminismo afro-latino-americano: ensaios, interveções e diálogos. Rio de Janeiro: Zahar, 2020.

RISÉRIO, Antônio. Oriki orixá. São Paulo: Perspectiva, 1996.

SANTIAGO, Jocevaldo. Agô. Salvador: Segundo Selo, 2020.

SIQUEIRA, Maria de Lourdes Siqueira. Os Orixás na vida dos que neles acreditam. Belo Horizonte: Mazza, 1995. SANTOS, Juana Elbein dos. Os Nagô e a Morte: Pàde, Àsèsè e o Culto Égun na Bahia; 11. ed. - Petrópolis, Vozes, 2002.

SOUZA, Neuza Santos. Tornar-se negro: as vicissitudes da identidade do negro brasileiro em ascensão social. Rio de Janeiro: Edições Graal, 1983.

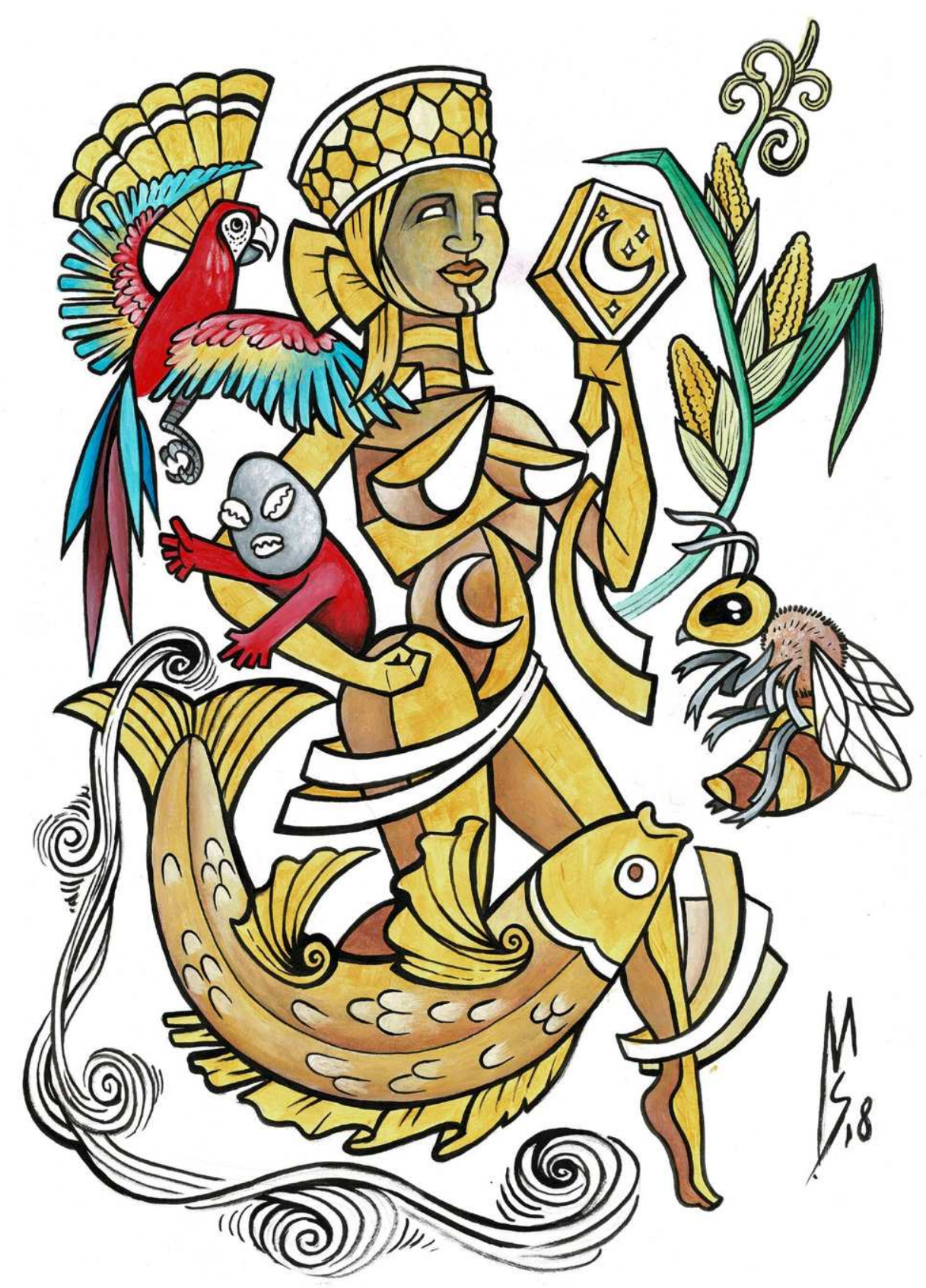




\section{ELEMENTOS DO CANDOMBLÉ QUE MAIS \\ RECEBEM INTERPRETAÇÕES NEGATIVAS ORIUNDAS DO RACISMO RELIGIOSO}

Gustavo Jaime Filizola Denise Maria Botelho

$$
\text { Òsun }{ }^{118}
$$

Òrìsà real de Òsogogo Genitora feminina, detém os princípios femininos da existência. Cabaça-ventre - poder de gestação. Aquela que cuida e protege a gestação e o bebê, que acompanha o desenvolvimento da criança.

É a genitora por excelência!

Ìyá-mi-Àkókó - mãe ancestral suprema.

Ligada à procriação,

detém o sangue vermelho

do corrimento menstrual - Ohun-omobìrin.

Senhora da fertilidade.

Òsùn - Olóri-İyá-mi-eléye

está associada à descendência no Àiyé.

Òrișà das águas correntes,

- aquela que é peixe,

- aquela que é pássaro - İyá-àgbà.

Ooșùn, a riqueza da fertilidade,

a riqueza enquanto bem coletivo.
118 Oríkì (louvação) para ọ̀șùn, construído a partir das obras: "Os Nàgô e a Morte: Pàde, Àsèsè e o culto Égun na Bahia", de Juana Elbein dos Santos (2012); e "Dicionário yorubá-português", de José Beniste (2011).

\section{Introduç̧ão}

Este texto é um recorte da minha dissertação de mestrado intitulada: "As Crianças de Candomblé e a Escola: pensando sobre o racismo religioso", orientada pela Profa. Dra. Denise Maria Botelho e defendida em 2019, através do Programa de Pós-Graduação em Educação, Culturas e Identidades da Universidade Federal Rural de Pernambuco e Fundação Joaquim Nabuco.

Acompanhando diariamente ações preconceituosas e discriminatórias motivadas por questões raciais, étnicas e religiosas através dos meios de comunicação (rádio, televisão, jornal e redes sociais), percebemos que as religiões de matriz africana são as vítimas mais frequentes de discriminação religiosa ${ }^{119}$. A partir da perspectiva dos estudos decoloniais, temos como objetivo analisar os principais elementos do candomblé que recebem interpretações negativas oriundas do racismo religioso ${ }^{120}$. Tentaremos mostrar, neste capítulo, que esse racismo tem origem na construção histórico-social que se desenvolveu a partir da conquista e colonização das Américas, através do modo hegemônico e dilacerante de lidar com as religiões que fugiam do padrão eurocêntrico, construção essa fundamentada no padrão moderno/colonial.

Neste capítulo, trazemos os conceitos de colonialismo, colonialidade, candomblé, cosmopercepção, racismo religioso, assim como conhecimentos sobre: Exu, axós ${ }^{121}$, ilequês ${ }^{122}$, toadas, cantigas e atabaques, e imolação de animais.

119 O Relatório sobre Intolerância e Violência Religiosa no Brasil (2011-2015): resultados preliminares (2016) indica os impactos negativos do neopentecostalismo para uma convivencia respeitosa entre religiosos. A partir da análise de materias de jornais que trataram de interionas,

120 Oestudo foi construído em uma perspectiva do racismo religioso, pois a intolerância, como fenômeno iso-

lado, não é suficiente para explicar os comportamentos discriminatórios com as religiõo

122 Ilequês em Yourubá İlệkè significa contas de um colar, um fio de contas (BENISTE, 2016, p. 374). 
Os estudos decoloniais objetivam a superação de um padrão de poder político, epistêmico e subjetivo, oriundo de um sistema capitalista hierárquico baseado na racialização e no eurocentrismo.

Anibal Quijano (1992) e Ramón Grosfoguel (2009) pensam de forma semelhante ao diferenciar colonialismo de colonialidade. Ambos afirmam que são ideias distintas. Grosfoguel (2009, p. 53) informa que "Colonialidade e modernidade constituem duas faces de uma mesma moeda". Mais adiante, vai explicar que usa "a palavra 'colonialismo' para se referir a 'situações coloniais' impostas pela presença de uma administração colonial, como no caso do período do colonialismo clássico" (GROSFOGUEL, 2009, p. 53).

Seguindo os passos de Aníbal Quijano (1992), Ramón Grosfoguel (2009) usa a designação "colonialidade" para se referir a situações coloniais da atualidade, onde as administrações coloniais foram praticamente erradicadas do "sistema-mundocapitalista", persistindo a opressão e a exploração cultural, política, sexual e econômica de grupos étnicos/ racializados que são subordinados por parte de grupos étnicoraciais dominantes, com ou sem a existência de administrações coloniais.

0 racismo religioso vem se caracterizar como a valorização dos conhecimentos, da religiosidade e cultura europeia em detrimento das culturas indígenas, africanas, ciganas e de outras etnias, ou seja, "uma hierarquia espiritual que privilegia os cristãos relativamente às espiritualidades não cristãs/não europeias institucionalizadas na globalização da igreja cristã (católica e, posteriormente, protestante)." (GROSFOGUEL, 2009, p.51).

Pensando sobre o Candomblé e as discriminações imputadas

Entre os séculos XVI e XIX, a diáspora africana trouxe uma infinidade de seres humanos da África para o "Novo Mundo". Durante muitos séculos o colonialismo foi a mola propulsora na passagem de corpos negros, via Oceano Atlântico, para as bandas de cá. Não sabiam que, dentro das embarcações, além de corpos, estavam transladando almas, seres humanos com imenso acervo cultural e religioso.

Como ressalvam Luiz Antônio Simas e Luiz Rufino (2018, p.43):

[...] as práticas culturais da diáspora africana tendem a transgredir qualquer tentativa de ajuste em esquemas binários. A potência transgressiva dessas práticas se dá na perspectiva de que as mesmas se assentam em outras bases de conhecimento de mundo. Esses conhecimentos operam sob outras perspectivas de invenção da realidade e de relações com as diferenças.

A configuração epistêmica da modernidade não se engendraria dentro da lógica dos terreiros de candomblé que, mais tarde, iriam se tornar espaços que proporcionariam a construção e o fortalecimento da própria identidade cultural das pessoas que ali participariam.

Segundo Patrícia Ricardo de Souza (2007, p.32):

O candomblé se formou no Brasil em meados do século XIX como uma organização original da diáspora de diversos povos africanos e, como religião de dominados, sofreu fortes pressões que poderiam ter levado à sua extinção. 0 que se verificou, no entanto, foi que a religião dos orixás não só sobreviveu como se expandiu e há muito tempo já não é mais uma religião de negros, mas universal, cujo alcance extrapola, inclusive, os limites das fronteiras nacionais.

No contexto das religiões de matriz africana, "[...] os terreiros surgem como espaços de uma articulação brasileira de um modo de vida complexo que carrega consigo algo que podemos chamar de um conjunto de espiritualidades herdadas dos povos africanos e reconstruídas aqui, de modo a tornarem-se afrodiaspóricas" (NASCIMENTO, 2017, p. 53).

A cosmopercepção ${ }^{123}$ africana e afro-brasileira vai de encontro à cultura hegemônica eurocêntrica construída ao longo do processo de colonização nas bases do capitalismo, do universalismo, da exclusão e do individualismo. "O candomblé se diferencia e se distancia do modelo europeu centrado nos poderes da organização capitalista e da racionalidade dos signos" (SODRÉ, 2017, p. 88).

Ao se referir às religiões africanas, assinala Eduardo Oliveira (2006, p. 67) que:

123 Utilizamos o termo cosmopercepção, ao invés de cosmovisão, apoiados nos estudos da pesquisador nigeriana Oyèrónkẹ́ Oyěwùmí (1997), que em seu livro "A invenção das mulheres: construindo um sentido africano para os discursos ocidentais de gênero" informa que o termo cosmovisão reproduz a importância da visão no pensamento ocidental, razão pela qual o mundo é percebido principalmente pela visão. A diferenciaação dos corpos humanos em termos de sexo, cor da pele e tamanho do crânio é um testemunho dos poderes que podem privilegiar outros sentidos. 0 termo "cosmopercepção" é uma maneira mais inclusiva de descrever que podem privilegiar outros sentidos. 0 termo "cosmopercepção" é uma maneira mais inclusiva de descrever podem privilegiar sentidos que não sejam o visual ou até mesmo, uma combinação de sentidos. 
[...] na África, as religiões jogam num papel primordial na organização da vida comunitária e na estruturação das sociedades africanas [...] as religiões africanas são eminentemente comunitárias. A dimensão comunitária dessas religiões expressa sua concepção de vida e do universo. O importante é o bem-estar de todos os membros da comunidade. [...] Os cultos visam harmonia social e espiritual[...] não há salvacionismo. Não há pecado. Longe dos paradigmas cristãos, as religiões africanas estão livres de noções como a culpa, paraíso e inferno-todas tributárias da concepção de tempo ocidental, ou seja, de um tempo futuro. As religiões africanas vivem, sobretudo de um tempo do passado, tempo dos antepassados [...] São religiões que sacralizam o tempo passado e o tempo presente.

A religião afro-brasileira marca presença no cenário das religiões existentes no Brasil. Os povos bantos tiveram participação importante nessa conjuntura. Essa etnia africana era predominante até o século XVIII; depois vieram os sudaneses que passaram a predominar no século XIX.

Sobre as nações africanas que aqui chegaram, evidencia Regiane Augusto de Mattos (2009) que com a intensificação do comércio dos/das escravizados/ as, os europeus passaram a identificar os diferentes grupos africanos por 'nações' como: minas, angolas, moçambiques, jejes, cabindas, entre outras. Essa classificação dos grupos, segundo ela, costumava ser feita, em alguma localidade na África, na ocasião do batismo do africano. "Os povos de língua iorubá (sudaneses) foram os que forneceram ao candomblé sua infraestrutura de organização, influenciada pelas contribuições dos demais grupos étnicos. Desse modo resultaram os dois modelos de cultos mais praticados: o rito jeje-nagô e o angola" (SILVA, 2005, p. 65).

0 terreiro de candomblé onde fizemos nossa pesquisa pratica o ritual jeje-nagô. Conforme Cândido Procópio Ferreira de Camargo (1961, p. 9): “No Brasil tornou-se preponderante a religião Sudanesa entre as modalidades religiosas de origem africana. 0 Xangô de Pernambuco e especialmente o Candomblé da Bahia são sobretudo expressões dos povos popularmente chamados Gêgê e Nagô, ambos Sudaneses".

Podemos observar que o xangô de Pernambuco, uma das variações regionais do candomblé do Brasil, é parente próximo do xangô de Alagoas, sendo praticado por vários terreiros na região metropolitana do Recife. Segundo Roberto Motta (2012, p.19), esse termo é usado em Sergipe, Paraíba e no Rio Grande do Norte, e "entrado o século XXI, o termo se tornou politicamente incorreto para uma parte dos líderes do culto em Pernambuco, que prefere o uso de candomblé, mais consagrado entre estudiosos e divulgadores".

O candomblé é o nome que recebeu a religião dos povos iorubás, trazida da Nigéria para o Brasil. Nele, a palavra nagô é sinônimo de iorubá, porém, para o chamado xangô no Recife, nagô é a denominação de uma das nações do candomblé, diferenciando do nagô dos candomblés baianos e cariocas, como por exemplo, Ketu e Ijejá que são nações nagô.

Já no século XIX, os últimos grupos chegados foram os jejes (de língua fon, também conhecidos como ewês) e os nagôs. Nagô tornou-se um nome genérico para a diversidade do complexo cultural, na verdade equivalente à palavra ioruba, designativa dos falantes desta língua, que em determinados momentos teve trânsito mais amplo na África. A insistência na denominação 'nagô' - mas também 'jeje-nagô' - conota, para nós, a pouca familiaridade brasileira com a diversidade étnica dos escravos, mas ao mesmo tempo a preponderância do comércio intenso entre a Bahia e a costa da África Ocidental, portanto, a manutenção do contato permanente entre os nagôs da diáspora escrava e as suas regiões de origem (SODRÉ, 2017, p.88-89).

Segundo Zuleica Dantas Pereira Campos (2013, p.15): "No decorrer do século $\mathrm{XX}$, os estudos sobre essas religiões de matriz africana, mais conhecida a partir da década de 1930 como xangôs, tomaram uma importância tal na antropologia que formou uma escola especializada nesses estudos". Autores como Ulysses Pernambucano, Waldemar Valente, Gonçalves Fernandes, Vicente Lima, René Ribeiro, Roberto Motta e Maria do Carmo Brandão são alguns nomes citados por ela como construtores de uma antropologia afro-pernambucana (CAMPOS, 2013).

Podemos dizer que o racismo religioso que recai sobre as religiões de matriz africana ocorre pela incompreensão que as colocava abaixo da "linha do humano" (FANON, 2008), e pela imposição do projeto sistema-mundo capitalista, patriarcal, cristão, moderno, colonial, europeu (GROSFOGUEL, 2009) que se perpetua desde o século XVI até os dias atuais. São as formas coloniais de dominação (GROSFOGUEL, 2009; QUIJANO, 1992), que permanecem mesmo que tenha se encerrado o colonialismo.

O projeto colonizador, desde o século XVI, funcionou e funciona como um mecanismo de colonialidade da dominação da cultura branca sobre os demais 
componentes étnicos e raciais, ou seja, da dominação das religiões de matrizes europeias sobre outras matrizes que se afastam dessa lógica cristã.

A própria vivência nas religiões de candomblé, somada às observações da pesquisa, permitem elencar os principais elementos do Candomblé que mais recebem interpretações negativas resultante do racismo religioso: orixá Exu, axós e ilequês, toadas e atabaques e imolação de animais.

Exu

Exu é o orixá da comunicação, mensageiro entre o Ayé e o Orum. Era o protetor das aldeias, casas, caminhos e encruzilhadas. Em países do continente africano e em Cuba também é conhecido como Legbá ou Elegbará. Foi, erroneamente, identificado pelos colonizadores com a figura do diabo da doutrina cristã.

De acordo com Luís de Câmara Cascudo (2001, p.107), era preciso uma justificativa moral para o tráfico dos negros e negras, Assim:

Só podiam existir duas fórmulas salvadoras. Trazer o condenado negro para escravo na América ou mandar o europeu "civilizar" a África, dominando-a. [...] Não há Demônio preto senão como presença católica do Branco. Não há mesmo um vocábulo próprio para designá-lo a não ser personalizando uma de suas atribuições. Psicologicamente, uma projeção cristã de Satanás.

Percebe-se então que os vocábulos "demônio" e "diabo" foram trazidos, pelos europeus católicos, para um sistema religioso dos africanos e africanas, que não estava baseado na dicotomia entre o bem e o mal. Relacionar Exu ao bem ou ao mal deixa de ter sentido, pois esse orixá nãoé classificado por esses critérios, dentro daquele sistema religioso. Segundo Vagner Gonçalves da Silva (2015, p. 17-18):

Entre as divindades cultuadas pelas religiões afro-brasileiras, nenhuma tem provocado tanta polêmica quanto Exu. Por se tratar de uma entidade associada à sexualidade e à fertilidade, seu culto de origem africana, quando descoberto pelos europeus séculos atrás, foi alvo de preconceitos e mal-entendidos. Sua demonização foi inevitável, tanto na África quanto nas Américas, para onde seu culto foi trazido, preservado e transformado pelas comunidades africanas e seus descendentes, num diálogo intenso com a colonização católica de moral maniqueísta e as práticas indígenas locais.
Sobre a associação de Exu ao demônio/diabo dos católicos, Vagner Gonçalves da Silva (2015, p.24) explica

Quando o seu culto foi 'descoberto' pelos europeus, iniciou-se um processo no qual a divindade foi associada ao imaginário do mal, da desordem e da repressão sexual no período medieval (ao demônio cristão e mulçumano) e, posteriormente ao mundo pré-moderno (primitivo), ao imaginário das forças antagônicas da modernidade, entre as quais estava, sobretudo, o pensamento mágico presente nas religiões que não passaram pelo processo da secularização ou burocratização.

Um exemplo que pode ser revelador desse processo, segundo o autor, é a associação entre o culto ao falo de Exu e o culto do diabo. Já que os chamados "ritos pagãos" eram condenados pela igreja católica na Europa e entre os povos colonizados, catequizados fora dela, por incluírem as cerimônias de fertilidade, nas quais era comum o uso de símbolos associados aos órgãos sexuais masculinos e femininos.

No Brasil, segundo Vagner Gonçalves da Silva (2015), a referência a Exu ou Legbá aparece em documento do século XVIII, identificando-o com o demônio, como já visto anteriormente, e na metade do século XIX, na imprensa escrita, em alguns noticiários de perseguição, feitas pela polícia aos frequentadores dos templos religiosos afro-brasileiros. Em periódicos dos anos de 1930, os frequentadores dos cultos afro-brasileiros eram chamados de forma pejorativa de "fiéis de Exu".

Exu é um grande injustiçado. Muitas das perseguições policiais no Governo de Getúlio Vargas aos terreiros de candomblé se deram por causa dessa visão colonizada de Exu como diabo ou demônio, transferindo para esse orixá atributos construídos pela visão cristã. Muitos dos adeptos eram chamados de adoradores do diabo, e hoje, nas escolas, as crianças de candomblé são chamadas de catimbozeiras, adoradoras do demônio.

Quanto às características desse orixá, Vagner Gonçalves da Silva (2015, p.23) diz que: "Exu, Legbá ou Elegbara são os nomes pelos quais é conhecido entre os atuais povos iorubas e fon-ewe, ambos da África Ocidental, a divindade mensageira, dinâmica, temida e respeitada, que deve ser saudada sempre em primeiro lugar para não atrair confusão ou vingança". 
Assim, dentro do Candomblé, Exu representa a vontade, o desejo, a sexualidade, a dúvida, sendo visto como trapaceiro, brincalhão, esperto ou malandro. Relaciona-se com os princípios da mobilidade, da transformação, das imprevisibilidades, linguagens, comunicação e, como é o orixá de toda forma de criação, é o senhor da fertilidade e é cultuado, geralmente, sob a forma de um falo ereto, nas entradas dos terreiros.

Nessa concepção religiosa, não se enquadram as ideias de inferno, nem de diabo e de pecado original, trazidas pelas religiões cristãs. Exu está longe de se parecer com o demônio dos católicos e evangélicos.

Juana Elbein dos Santos (2008) desenvolveu um trabalhado sobre Exu, o qual foi inspirado e é decorrente de um estudo sistemático sobre o Pàdé, cerimônia que resume a concepção simbólica do sistema religioso Nagô e o seu significado, a estrutura e as relações simbólicas de Exu. Exu, segundo ela,

[...] não só está relacionado com os ancestrais femininos e masculinos e com suas representações coletivas, mas ele também é um elemento constitutivo, na realidade o elemento dinâmico, não só de todos os seres sobrenaturais, como também de tudo o que existe (SANTOS, 2008, p.130).

Para o pesquisador Luiz Rufino Rodrigues Junior (2016), Exu é o princípio explicativo de mundo iorubano, trazido e ressignificado pelo movimento contínuo diaspórico africano. Ele é um signo pós-colonial e em seus domínios e potências representa as bases de um projeto político, epistemológico, educativo, antirracista, decolonial, que ele chama de "a pedagogia das encruzilhadas", através da qual, desatam-se nós para se lançar novas amarrações.

Assim, na compreensão desse autor, o investimento feito pelas religiões cristãs, como parte do projeto de dominação colonial, foi crucial para a construção de alguns demônios. Até hoje, o "diabo" insiste em amedrontar e nos assombrar. A figura de Exu incomodou e incomoda muita gente! Orixá que é capaz de desatar os nós e reinventar outros. Sobre o racismo religioso manifestado à cultura afrobrasileira, Luiz Antônio Simas e Luiz Rufino $(2018$, p.92) afirmam que: "é a força de Exu - o movimento como um todo - que nos dará força para reinventarmos os mundos, praticando caminhos por encruzilhadas. Laroiê! Mojubá Exu!".
Axós e Ilequês

Em nossa pesquisa, destacamos as vestimentas e os fios de conta que as crianças usam, devido ao compromisso delas com a religião ou mesmo por um processo de identificação. Os axós e os fios de contas ou guias são, dentro do candomblé, marcadores singulares quanto à identidade religiosa afro-brasileira.

É importante salientar que a diversidade dos axós e os fios de contas variam de terreiro para terreiro, de festa pública para festa pública, constituindo-se, assim, em um universo estético bastante complexo e cheio de significados. Cada orixá tem sua cor, variando de nação para nação, e, de cada cor são os fios de conta que os praticantes do Candomblé usam. Por exemplo, no candomblé nagô, quem é filho(a) de Iemanjá, usa roupas e contas azuis e/ou prateadas. Quem é filho(a) de Oxum, usa amarelo; Iansã, vermelho; para Orixalá, usa-se branco, etc.

Os fios de contas possuem um valor identitário para as crianças que os usam. No candomblé, seja para as crianças iniciadas que desempenham funções específicas ao receber cargos na hierarquia dos terreiros, seja para aquelas que não foram iniciadas, todas manifestam orgulho e alegria de usar suas vestimentas e seus colares coloridos, pois, para elas, tudo isso faz parte de sua identidade religiosa e do seu sagrado.

Observa-se que as vestimentas e contas, apesar de serem elementos de importante valor simbólico para essa religião, quando usadas pelas crianças na escola, podem gerar discriminação e sofrimento. Muitas crianças não vão à escola com seus fios de conta ou guias, ou algum outro acessório que possa identificá-las como pessoas ligadas ao candomblé, pois são elementos que frequentemente as pessoas associam com "coisas de macumba" ou "religião do diabo".

Qualquer que seja a religião afro-brasileira, o uso de colares, ou fios de contas, ou guias é bastante significativo. Mudam as formas, as cores e mesmo os significados, mas o fio sempre pode ser visto no pescoço dos devotos.

Quanto aos colares do candomblé, em sua dissertação de mestrado, Patrícia Ricardo de Souza (2007, p. 15) informa que:

Não se pode perder de vista que os colares, ou os ilequês como são chamados no candomblé, cumprem também o papel fundamental de enfeitar, o que certamente não é algo secundário porque adornar, tornar (mais) bonito é por sinal uma busca constante no candomblé. De todo modo, a principal 
finalidade do ilequê é dizer qual é o orixá da pessoa, é dar identidade. Além do mais, eles se destinam também a proteger quem os carrega.

Dentro da ritualística, percebe-se uma infinidade de tipos de colares. Eles são em geral compridos, até a cintura aproximadamente, e são sempre arrematados por um tipo de conta maior, arredondada ou cilíndrica. Os colares apresentam aos membros do candomblé um papel identitário expressivo, como afirma Patrícia Ricardo de Souza (2007, p. 17),

Quando um potencial adepto se aproxima do candomblé, o primeiro passo é a consulta ao oráculo para se saber a qual orixá aquele indivíduo pertence, qual é sua origem mítica. Uma vez que se sabe qual é o deus particular daquela pessoa, ela receberá um colar que a identificará como filha do orixá, havendo inclusive uma cerimônia para sacralizar o ilequê, chamada lavagem de contas.

Assim, os colares ou as guias podem ser tomados como o sinal de pertença às religiões afro-brasileiras e ao candomblé especificamente. "Nas trajetórias de inserção dos adeptos ele aparece como o primeiro elemento material sagrado com o qual se tem contato" (SOUZA, 2007, p. 18).

Para uma criança ou adolescente, receber um ilequê de presente é sinal de estima e reverência. Trata-se de um gesto muito significativo, pois é uma forma da pessoa se sentir reconhecida e amada. Usá-lo, é uma forma de se sentir protegido pelo axé de seu próprio orixá.

Percebe-se que nas diversas religiões a vestimenta é uma linguagem simbólica importante para todo o grupo religioso. Há sempre um cuidado todo especial com o vestuário para a participação nos ritos. Como assinala Patrícia Ricardo de Souza (2007, p. 45):

Um exemplo dos mais ilustrativos nesse sentidoéo dos evangélicos tradicionais do país inteiro; entre esses a saia abaixo dos joelhos e as roupas pouco decotadas para as mulheres, e o terno e gravata para os homens acabaram se constituindo um traço distintivo da pertença onde quer que estejam. Essa identidade evangélica sinalizada pelo modo de vestir se mostra de modo muito marcante nas periferias em que o contraste com os trajes simples dos outros moradores é forte e também porque é aí que essas igrejas têm maior presença.
No candomblé, não é diferente. Os adeptos dessa religião usam trajes específicos, tanto para a vivência religiosa cotidiana no terreiro quanto para o ritual público, que é a festa. Essa é, aliás, a ocasião em que a linguagem simbólica da vestimenta se manifesta de forma mais plena. Porém, esses trajes recebem discriminações por parte de outros religiosos, em destaque, participantes de religiões de matriz europeia como os evangélicos, católicos e espíritas (kardecistas).

Elucida Patrícia Ricardo de Souza (2007, p. 46) que,

[...] todo o vestuário do candomblé tem como referências essenciais a África, de um modo bastante abrangente porque sabe-se que os escravos trazidos para o Brasil vieram de diversos lugares do continente africano; o período da escravidão, dadas as condições em que a religião dos orixás se formou ainda sob o regime escravista, e a moda feminina europeia do século XVIII que era divulgada no Brasil por meio de revistas e mesmo das pessoas que vinham de suas estadias no velho continente.

Acreditamos que a forma de vestir-se dos integrantes das religiões afrobrasileiras, cuja origem é o continente africano, seja a razão dessa discriminação religiosa contra seus adeptos.

As mulheres usam saias, saiotes e calçolão. Segundo Hanayrá Negreiros de Oliveira Pereira (2017, p. 99),

[...] as saias para indumentária de candomblé são heranças deixadas dos tempos coloniais, uma peça estruturada de forma ampla, com camadas de saiotes, rendas, fitas e bordados que também demonstram hierarquia para o povo de santo. As saias mais rodadas, feitas nos tecidos mais estampados só podem ser usadas pelas equedes e ebômis. [...] As saias menos armadas e mais simples em suas composições, são usadas pelas abiãs, e iaôs com menos de sete anos de iniciação.

Salientamos que Equede é o nome dado para um cargo feminino de "zeladora dos orixás" escolhida e confirmada pelo orixá do terreiro de candomblé e não entram em transe. A iaô que, após sete anos, ofertadas as obrigações devidas, passa de iniciada à Ebômi, e ao receber o dekà (cuia do axé), poderá iniciar outras pessoas, assumindo a direção de outro terreiro. Abiã é a pessoa ainda não iniciada. 
Ainda como parte da vestimenta, destacamos os torços ou turbantes, que são usados com mais frequência em mulheres e crianças do sexo feminino, com a finalidade de proteger a cabeça, o ori, daquela que o carrega. "É muito comum que sacerdotes e sacerdotisas, pessoas da alta hierarquia, usem seus torços maiores e mais elaborados em aparições públicas, e nesse caso essa peça ajuda a compor e expressar essa identidade afro-descendente" (SOUZA, 2007, p.55).

As crianças do sexo masculino usam pequena touca feita de crochê ou pano, em sua maioria de cor branca com algumas variações, também usados para proteger a cabeça (ori), camisa branca ou bata, que pode ser mais elaborada com algum bordado. As calças geralmente usadas de cor branca, mas podendo também ser feitas de cores diferentes e com bordados.

Toadas, cantigas e atabaques

O candomblé, como prática ritualística descendente de africanos, representa a afirmação de valores ligados às questões do sagrado e das práticas simbólicas e culturais, tendo a oralidade como chave e detentora mais importante para a realidade dos terreiros.

Segundo Denise Maria Botelho (2012, p. 2), "uma das principais marcas da maioria das culturas africanas que chegaram ao Brasil é a oralidade". A palavra nos terreiros de candomblé tem o poder de multiplicar conhecimentos e fortalecer a cultura e a memória das sociedades africanas. Ela se manifesta, seja através de uma história contada, seja por um ensinamento dado pelos mais velhos aos mais novos, pois "a palavra é força, e a palavra carregada de axé introjetado é envolta de sacralidade e de poder" (LUZ, 2017, p. 391).

A presença da palavra se dá também em algumas toadas que conduzem a ligações intrínsecas entre memória e linguagem oral, fortalecem a identidade em seu embasamento histórico, possibilitando manter vivas línguas africanas como o iorubá, e visibilizando a complexidade das culturas negras.

Ao se referir aos toques de candomblé, José Beniste (2012, p. 72) evidencia,

[...] toque de candomblé é o mesmo que festa, pois se refere às batidas dos atabaques, que possuem uma variedade significativa de ritmos identificados com a necessidade do momento. Sem música não há cerimônia. São mais de 15 ritmos diferentes, acompanhados de cânticos ou não. Esses toques têm o poder de entrar em sintonia com os Òrisà, pois fornecem elementos como gestos e movimentos do corpo que entram em afinidade de forma irresistível.

Para a realização das festas ou toques que serão movimentados por toadas, cânticos e danças, são necessárias as presenças dos Ogãs ou Ogans. Todos os terreiros têm seus Ogans, que estão familiarizados com os costumes da Casa, podendo, porém, permitir que outros visitantes venham a tocar. Sobre a importância dos atabaques e ogãs para o candomblé, José Beniste (2012, p 74) explica que:

Os atabaques são tocados por Ogans confirmados da Casa ou por visitantes importantes, merecedores de homenagens especiais. [...] Alguns atabaques são muitos antigos e por isso, são investidos de uma importância ritual enorme. São instrumentos sagrados [...] É através do ritmo dos atabaques que os Òrisà chegam à Terra, daí a sua importância.

É muito comum ouvirmos essa afirmação: "Tocar tambor é coisa do demônio". Em uma frase dita dessa forma, percebe-se uma forte relação com ideias eurocêntricas e racistas. Uma forte presença de preconceito que associa pejorativamente tambor a "coisa de negro", e sendo de negro, é considerado ruim.

Em Alagoas de 1912, segundo Ulisses Neves Rafael (2004) em sua tese de doutorado, ao estudar a perseguição sofrida pelos terreiros naquele Estado, verifica um dos episódios mais violentos na história dos chamados cultos afro-brasileiros. No caso, a "operação xangô", como ficou também conhecido o quebra-quebra liderado por integrantes da Liga dos Republicanos Combatentes, associação civil de caráter miliciano, e que implicou na destruição das principais casas de culto da capital e de municípios circunvizinhos. Nesse momento, os terreiros ficaram temporariamente calados, surgindo uma modalidade exclusiva de culto: o "xangô rezado baixo". Os tambores foram, momentaneamente, silenciados.

Nas nossas observações em terreiros, percebo os ilus ${ }^{124}$ como instrumentos sagrados que as crianças adoram chegar perto, tocar e produzir sons com suas mãos. São crianças de quatro, cinco anos. Se no terreiro o ilú é algo mágico, que produz felicidade, na escola, é visto como "coisa do mal".

124 Ilú, em Yorubá İlú, Tambor, um tipo de toque de atabaque (BENISTE, 2016, p. 376). São promotore 
"É sempre tempo de reconhecer e estudar as possibilidades didáticas que os atabaques tiveram na formação das crianças de terreiro e escolas de samba" (SIMAS; RUFINO, 2018, p.62). Há um processo pedagógico por trás desses tambores, que se transformam em livros para essas crianças, e com suas mãos, verdadeiros lápis, produzem uma espécie de textualidade, "de saberes que se cristalizaram formalmente nos bancos acadêmicos e escolas padronizadas" (SIMAS; RUFINO, 2018, p. 63).

Na escola formal as práticas pedagógicas estão "empoderadas" de orientações religiosas opostas às que as crianças recebem no terreiro e que reforçam as práticas excludentes e discriminatórias ao prevalecer a cultura hegemônica da sociedade, à medida que essas práticas docentes são orientadas pelas crenças do(a) professor(a).

Imolação de animais

É fato que muitas pessoas se apegam ao rito da imolação dos animais para dizer que o candomblé é uma religião primitiva, do diabo e sem "Deus" e que cultua deuses sanguinários. Quanto à visão negativa desses ritos, percebe-se que é oriunda de um total desconhecimento do contexto e do significado que essa prática tem para os praticantes da religião do candomblé

Vilson Caetano de Sousa Junior (2011, p. 59-61) pontua que,

[...] as vezes que ouvimos inúmeras críticas sobre o sacrifício nas religiões de matriz africana. Se por um lado esse desconforto pode ser explicado a partir de alguns preconceitos relacionados a estas religiões, essa aversão ao sacrifício também é historicamente construído. [...] 0 sacrifício, historicamente, está presente na maioria dos modelos religiosos construídos pelos povos mais antigos, a partir do Cristianismo, ganhou uma conotação de algo violento e cruel.

Esse autor alerta que, para compreendermos o real significado do sacrifício nas religiões de matriz africana, temos que nos afastar de alguns preconceitos e ampliar nossa percepção sobre o assunto.

Denise Maria Botelho (2017) comunga do pensamento de que há um racismo religioso em relação às religiões de matriz africana. No vídeo lançado pela Universidade Federal Rural de Pernambuco, a autora explica,
Deparamo-nos hoje com um cenário chamado de intolerância, que efetivamente, eu acho que é algo mais do que intolerância, trata-se de racismo religioso [...] a principal situação de perseguição das religiões afro-indígenas está presente, na realidade, nas nossas práticas, dos nossos ritos religiosos. [...] nos nossos ritos religiosos há o abate de animais, mas não apenas as religiões de matrizes africanas que aqui posso nomear enquanto candomblé, enquanto a Umbanda, enquanto a Jurema e outros segmentos, porque você vai ver que os judeus fazem abates religiosos, mas eles não têm o grau de perseguição que as religiões de matriz africanas têm [...] assumo a perspectiva do racismo religioso porque ele está direcionado às casas de candomblé, às casas de Jurema às casas de Umbanda (BOTELHO, 2017, 0m25s)

Por isso, ao ser convidada para falar sobre a intolerância religiosa, a professora Denise Botelho prefere definir como "racismo religioso", uma vez, que se percebe que outros segmentos religiosos se utilizam do abate religioso e, contudo, não são perseguidos como os/as participantes das religiões afro-indígenas.

Em um dos seus artigos, Wanderson Flor do Nascimento (2015) traz algumas elucidações sobre o papel da alimentação no pensamento tradicional africano, em especial, sobre a imolação de animais dentro das comunidades de candomblé.

A partir de uma visão de que a força vital que habita em todos os seres vivos precisa ser mantida em equilíbrio para que o mundo siga existindo em suas diversas relações, a alimentação é vista, segundo Wanderson Flor do Nascimento (2015, p.63) como:

[...] um dos processos nos quais este equilíbrio deve ser mantido e, também deve ser mantido o equilíbrio social das comunidades que se alimentam. [...] é uma espécie de ciclo fechado: onde a alimentação cria um ambiente propício para que o gesto de comer seja utilizado como parte dos processos de socialização entre as pessoas que vivem comunitariamente.

Assim, os alimentos, embora sejam consumidos de forma individual, são produzidos de forma coletiva, propiciando o fortalecimento dos laços comunitários. Segundo esse autor, é importante notar que:

[...] para as sociedades tradicionais africanas, as divindades compõem o tecido social da mesma maneira que as pessoas, precisando também de se alimentarem e contribuírem para os 
ciclos que promovem a possibilidade de que o alimento continue existindo para todo o mundo. (NASCIMENTO, 2015, p.63).

Dentro da cosmopercepção africana, a ancestralidade é um dos elementos mais constantes na cultura africana. Os estudos na área mostram que é um fenômeno presente praticamente em toda a África, antes da chegada dos europeus e do processo de colonização.

A ancestralidade é um dos elementos centrais de grande parte dos povos africanos. Afirmando esse pensamento, Wanderson Flor do Nascimento (2012, p. 46) diz que:

[...] esta é o motor da história que se dobra sobre seus filhos, estabelecendo uma tradição e modificando o mundo. A ancestralidade não é apenas uma relação que se estabelece com os ancestrais: é também, e sobretudo, uma lógica de continuidade que confere sentido - desde o presente - ao passado, que dá forma à memória, permitindo projetar futuros. Desta forma, a ancestralidade aparece, nesses povos, como um dos fundamentos da própria cultura, que seguindo a dinâmica ancestral não será jamais estática. A ancestralidade é sempre uma experiência relacional, que liga, inclui e se move na perspectiva da multiplicidade - haja vista que somos herdeiros de diversos ancestrais.

A noção de comunidade dentro dos terreiros se contrapõe à perspectiva individualista e egocêntrica do capitalismo. Pensar de forma circular é considerar que precisamos ir ao encontro do outro. Ratificando esse pensamento, Eduardo Oliveira (2006, p. 49) explica:

As religiões africanas são eminentemente comunitárias. A dimensão comunitária dessas religiões expressa sua concepção da vida e do universo. 0 importante é o bem-estar de todos os membros da comunidade. Não existe divisão de classes ou privilégios sociais. Os benefícios da religião e da religiosidade são universais (para o grupo, família, clã ou cidade).

Comunidade, ancestralidade, alimentação, terreiro são palavras-chave de um processo bem maior, que foge aos olhos daqueles que não conhecem em profundidade a dinâmica que acontece dentro dos candomblés. "No terreiro, a alimentação é estabelecida de relações: com as divindades, com a natureza, consigo mesmo, com as outras pessoas da comunidade religiosa. E como tudo se alimenta, tudo se relaciona comunitariamente no interior do terreiro" (NASCIMENTO, 2015, p. 65). Dentro de uma rede de relações, oferece-se à divindade tudo aquilo que a comunidade come, porque aquela também pertence a essa e come tudo que a comunidade comer. Porém, diz esse autor que "é comum que os ancestrais comam primeiro, embora em conjunto com as outras pessoas" (NASCIMENTO, 2015, p. 64).

Como vimos, sendo o candomblé uma religião ancestral com seus ritos, liturgias e tradição, o abate religioso de animais é completamente diferente do abate comercial, os babalorixás conversam, alimentam e cantam para o animal, para que ele seja sacralizado.

Segundo Erisvaldo Pereira dos Santos (2015, p.53),

[...] é uma sacralização e nada tem de violência ou barbárie. Os animais são sacralizados em contextos de rituais propiciatórios, seguindo um conjunto de preceitos e cuidados transmitidos pela tradição religiosa. Suas partes são distribuídas em um banquete comunitário, onde as divindades emanam e compartilham forças e energias vitais com aquelas pessoas que vivenciam essa experiência do sagrado.

Interessante que, neste processo, percebemos que mesmo quem não é participante do terreiro também é convidado a se alimentar. A imolação dos animais acontece porque, nesse sentimento comunitário, todo mundo tem que comer. 0 sangue que não nos alimenta, alimenta as divindades. Assim, todos comem juntos, divindades, participantes, convidados e comunidade como um todo. Come-se junto, porque se vive junto.

No dia 09 de agosto de 2018, Ministros do Supremo Tribunal Federal se reuniram para julgar o Recurso Extraordinário no. 494601 sobre a legalidade dos sacrifícios de animais em ritos religiosos das religiões de matrizes afro-brasileiras. Durante a sessão, os ministros Marco Aurélio Mello e Edson Fachin votaram a favor da prática, porém o julgamento foi interrompido porque o ministro Alexandre de Moraes pediu vista, ou seja, mais tempo para analisar o caso. A discussão do referido recurso só foi concluída no dia 28 de março de 2019. Com a Presidência do Senhor 
Ministro Dias Toffoli, estiveram presentes à sessão os Senhores Ministros Marco Aurélio Mello, Gilmar Mendes, Ricardo Lewandowski, Cármen Lúcia, Luiz Fux, Rosa Weber, Roberto Barroso, Edson Fachin e Alexandre de Moraes, na qual, por maioria, fixou-se a seguinte tese ${ }^{125}$ : "É constitucional a lei de proteção animal que, a fim de resguardar a liberdade religiosa, permite o sacrifício ritual de animais em cultos de religiões de matriz africana".

Nos rituais onde há a imolação, alerta-nos Wanderson Flor do Nascimento que,

[...] se a comunidade não puder se fortalecer com a imolação, é melhor que ela não aconteça. Matar por matar é uma das mais importantes causas de infortúnios que a percepção africana da realidade pode imaginar. Deste modo, em um mundo onde tudo é vivo, para manter a vida é preciso dedicar a vida de alguns viventes a essa tarefa de manutenção. E se matar é inevitável, nos cabe encontrar a melhor maneira para fazê-lo, sem crueldade, minimizando a dor, festejando e ofertando ao doador de seu corpo aquilo que ele gosta. Afinal, é isso que também acontece aos existentes humanos, para esse entendimento da realidade. Os seres humanos também um dia serão mortos e servirão de alimento para a terra e para os animais que nela vivem. E assim como evitamos a crueldade com humanos, deve-se evitar a crueldade com todos os outros existentes que compõe a grande comunidade viva da Terra (NASCIMENTO, 2015, p.69).

O que o autor quis mostrar é que o candomblé traz em sua essência o respeito por toda espécie de ser vivente, desenvolve uma consciência ecológica e mostra que tudo tem uma finalidade de existência. Há uma grande responsabilidade para aqueles que praticam a imolação de animais. Uns morrem para que outros possam viver, seguindo o curso da vida em constantes mudanças. O pensamento comunitário africano, nos terreiros, se sobrepõe ao pensamento individual da modernidade.

\section{Considerações finais}

Embora seja crime, de acordo com a Constituição (BRASIL, 1988), um dos graves problemas de nossa atualidade manifesta-se nas diversas formas de racismo 125 0 documento pode ser acessado pelo endereço: http://www.stf.jus.br/arquivo/cms/noticiaNoticiaStf/anexo/RE494601MMA.pdf. Acesso em: 24. out. 2020. presentes em nossa sociedade, tais como: o epistêmico, o estrutural, o institucional, o cultural, o religioso, entre outros. A sociedade, constantemente, tem testemunhado atitudes de desrespeito e violência em relação aos negros e às negras, e aos praticantes das religiões de matriz afro-indígena em geral.

Analisamos os ideais eurocêntrico-cristãos comogeradores da discriminação, através da (re)produção do racismo religioso, em relação aos candomblecistas e que são promovidos por outras religiões, em especial alguns segmentos da igreja católica e setores das igrejas neopentecostais. Essas concepções têm sua origem desde a colonização, com o processo de escravização, até os dias atuais, com as formas de colonialidade que continuam colocando as religiões de matrizes africanas e afrobrasileiras numa posição inferior e de primitividade.

Diante do exposto, há uma necessidade urgente de discutir nos terreiros os conhecimentos dos elementos e valores culturais e civilizatórios africanos e afro-brasileiros presentes nas religiões afro-brasileiras. Conhecimentos esses que fortalecerão um pensar teológico/filosófico africano afrocentrado como forma de ser, ver e estar no mundo bioafro-ancestral, e que difere, radicalmente, de uma concepção judaico-cristã, católica, baseada no dualismo cartesiano.

Que outros estudos possam contribuir para a desmarginalização da tradição de matriz africana e de seus símbolos, de forma a interceptar os efeitos do racismo semiológico e semântico.

\section{Referências}

BENISTE, José. As águas de Orixalá: àwon omi Ósàlá. Rio de Janeiro: Bertrand Brasil, 2012. BENISTE, José. Dicionário yorubá-português. 3. ed. Rio de Janeiro: Bertrand Brasil, 2016.

BOTELHO, Denise Maria; NASCIMENTO, Wanderson Flor do. Educação e religiosidades afro-brasileiras: a experiência dos candomblés. Participação, Brasília, n. 17, p. 74-82, 2012

BOTELHO, Denise Maria. UFRPE. UFRPE pelos Direitos Humanos. Racismo Religioso. 2017. 1 vídeo (5m56s). Disponível em: https://www.youtube.com/watch?v=UbajJvqKfUk.

BRASIL. Constituição da República Federativa do Brasil: promulgada em 5 de outubro de 1988. Brasília, DF: Senado Federal: Centro Gráfico, 1988.

CAMARGO, Cândido Procópio Ferreira de. Kardecismo e Umbanda: uma interpretação sociológica. São Paulo: Pioneira, 1961.

CAMPOS Zuleica Dantas Pereira. De xangô a candomblé: transformações no mundo afro-pernambucano. Horizonte, Revista de Estudos de Teologia e Ciências da Religião da PUC Minas. Belo Horizonte, v. 1 , n. 29 , p. $13-27,2013$ 
CASCUDO, Luís da Câmara. Made in Africa. São Paulo: Global, 2001.

FANON, Frantz. Peles negras, máscaras brancas. Salvador: EDUFBA, 2008.

GROSFOGUEL, Ramón. Para descolonizar os estudos de economia política e os estudos pós-coloniais: transmodernidade, pensamento de fronteira e colonialidade global. Revista Periferia, Rio de Janeiro, v. 1, n. 2, p. 41-91, jul./dez. 2009.

LUZ, Marco Aurélio. AGADÁ: dinâmica da civilização africano-brasileira. 4.ed. Salvador: EDUFBA, 2017. MATTOS, Regiane Augusto de. História e cultura afro-brasileira. São Paulo: Contexto, 2009.

MOTTA, Roberto. Transe, nome, identidade e reconhecimento no xangô de Pernambuco. In: BRANDÃo, Sylvana; MARQUES, Luiz Carlos Luz; CABRAL, Newton Darwin de Andrade. História das Religiões no Brasil. Recife: Bagaço, v. 6, 2012. p. 17-30.

NASCIMENTO, Wanderson Flor do. Alimentação socializante: notas acerca da experiência do pensamento tradicional africano. Revista das Questões, n. 2, p. 62-74, 2015.

NASCIMENTO, Wanderson Flor do. 0 fenômeno do Racismo Religioso: desafios para os povos tradicionais de matrizes africanas. Revista Eixo, Brasília, v.6, n.2 (especial), p.51-56, 2017

NASCIMENTO, Wanderson Flor do. Jindengue - Omo Kékeré: notas desde alguns olhares africanos sobre infância e formação. In: XAVIER, Ingrid Müller; KOHAN, Walter Omar (org.). Filosofar: aprender e ensinar. Belo Horizonte: Autêntica, 2012. p. 41-52.

OLIVEIRA, Eduardo. Cosmovisão Africana no Brasil: elementos para uma filosofia afrodescendente. 2.ed. Curitiba: Popular, 2006.

OYĚWÙMÍ, Oyèrónké. A invenção das mulheres: Construindo um sentido africano para os discursos ocidentais de gênero. Tradução de Wanderson Flor do Nascimento. Minneapolis: University of Minnesota Press, 1997.

PEREIRA, Hanayrá Negreiros de Oliveira. O Axé nas roupas: indumentária e memórias negras no candomblé angola do Redandá. 2017. Dissertação (Mestrado em Ciência da Religião) - Programa de Estudos Pós-Graduados em Ciência da Religião, Pontifícia Universidade Católica de São Paulo, São Paulo, 2017.

QUIJANO, Aníbal. Colonialidad y Modernidad/Racionalidad. Peru Indígena, Lima, v. 13, n.29, p.11-20 1992

RAFAEL, Ulisses Neves. Xangô rezado baixo: Um estudo da perseguição aos terreiros de Alagoas em 1912. 2004. Tese (Doutorado em Sociologia e Antropologia) - Instituto de Filosofia e Ciências Sociais, Universidade Federal do Rio de Janeiro, Rio de Janeiro, 2004

RIVIR - Relatório sobre Violência Religiosa e Intolerância no Brasil (2011-2015). Resultados Preliminares. Brasília: Secretaria Especial de Direitos Humanos do Ministério das Mulheres, da Igualdade racial, da juventude e dos Direitos Humanos, 2016.

RODRIGUES JUNIOR, Luiz Rufino. Exu e a Pedagogia das Encruzilhadas. Seminário dos alunos do PPGAS/ MN, UFRJ. Rio de Janeiro: Museu Nacional, 2016.

SANTOS, Erisvaldo Pereira dos. Formação de professores e religiões de matrizes africanas: um diálogo necessário. 2.ed. Belo Horizonte: Nandyala, 2015.

SANTOS, Juana Elbein dos. Os Nagôs e a Morte. Petrópolis: Vozes, 2008.

SILVA, Vagner Gonçalves da. Candomblé e Umbanda: caminhos da devoção brasileira. 5. ed. São Paulo: Selo Negro, 2005

SILVA, Vagner Gonçalves da. Exu: o guardião da casa do futuro. Rio de Janeiro: Pallas, 2015.
SIMAS, Luiz Antônio; RUFINO, Luiz. Fogo no mato: a ciência encantada das macumbas. Rio de Janeiro Mórula, 2018.

SODRÉ, Muniz. Pensar Nagô. Petrópolis, RJ: Vozes, 2017.

SOUSA JUNIOR, Vilson Caetano de. Na palma da minha mão: temas afro-brasileiros e questões contemporâneas. Salvador: EDUFBA, 2011.

SOUZA, Patrícia Ricardo de. Axós e Ilequês: Rito, mito e a estética do candomblé. 2007. Dissertação (Mestrado em Sociologia) - Departamento de Sociologia, Universidade de São Paulo, São Paulo, 2007. 


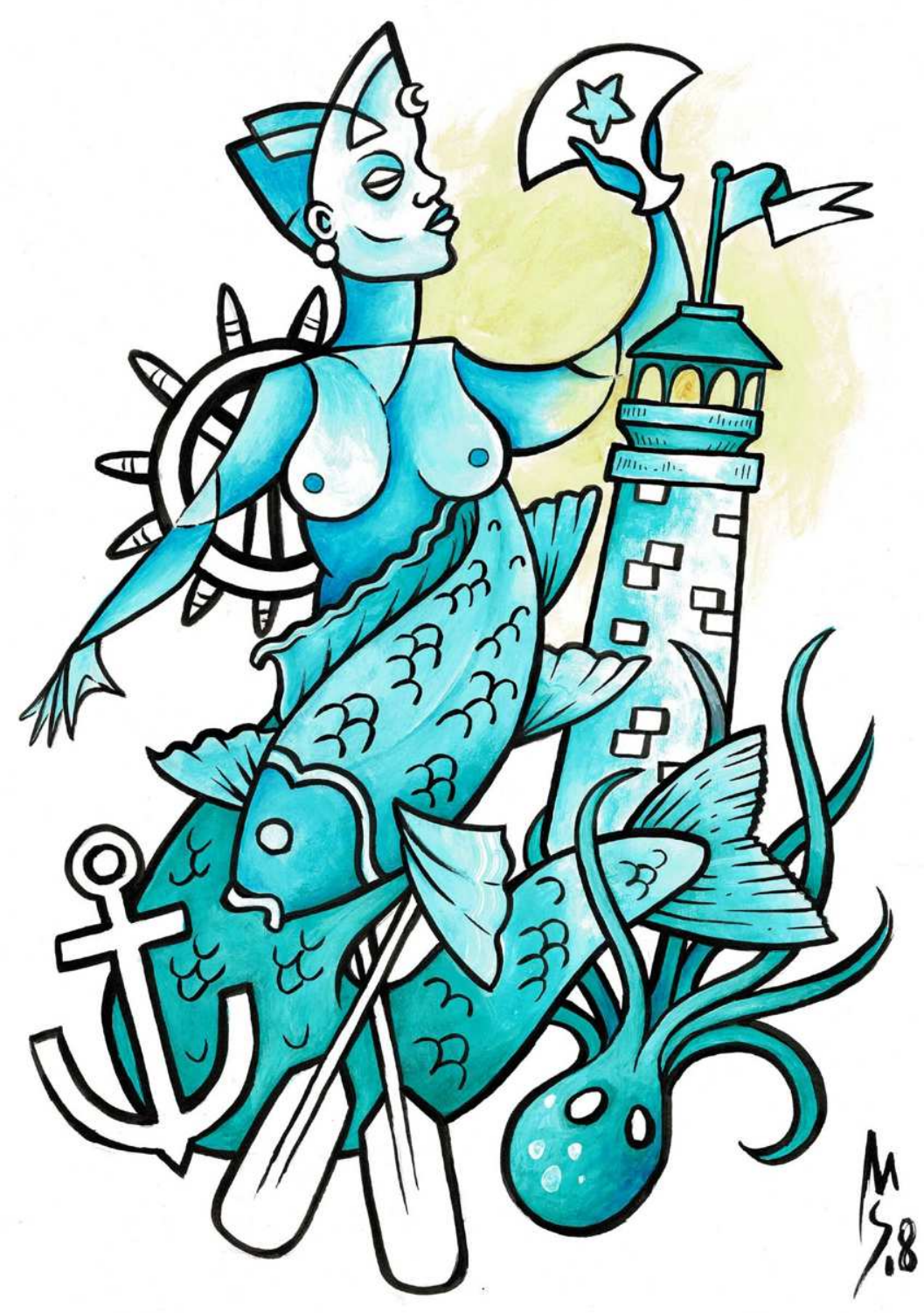

\section{Yemojá⿴囗十}

Yemojá - mãe cujos filhos são peixes. Está ligada ao princípio físico e fenomenológico das águas.

Atua para que as pessoas

compreendam seus compromissos com o coletivo, - exacerba e potencializa o projeto mítico-social. Na diáspora,

assume o papel de mãe que orienta, que mostra os caminhos,

$$
\text { que educa, }
$$

que sabe explorar as potencialidades que estão dentro de cada um. É a cuidadora de todos os Orí-Inú A mãe que não faz distinção dos seus filhos, tenham ou não saído do seu ventre.

126 Oríkì (louvação) para Yemojá, construído a partir das obras: "Os Nàgô e a Morte: Pàde, Àsèsè e o culto Égun na Bahia", de Juana Elbein dos Santos (2012); e "Dicionário yorubá-português", de José Beniste (2011) 


\section{ELEMENTOS DA MEMÓRIA E DA BENZEDURA:}

A PRÁTICA AFRODIASPÓRICA DE CURA NA CIDADE DE PELOTAS/RS

Ana Paula Melo da Silva

\section{"Eu que te benzo, Deus que te cure"127}

Sapinho, quebranto, bicho-de-pé, espinhela caída, bronquite, dor de barriga, íngua, verruga, dor de Sol, brotoeja, enguiço, peito aberto, terçol... esses e tantos outros males, conhecidos como "doenças de benzedeiras", e por vezes tratados com ramos, pedrinhas de riacho, sob a luz da Lua, com tecido, agulha e linha, garrafadas, escalda-pés, chás, xaropes e demais elementos, quando utilizados nos processos de cura e incorporados nos rituais, desempenham novas funções e asseguram melhoras.

A benzedura, muito comum em todo território brasileiro, demonstra a força dos saberes transmitidos oralmente, da tradição ancestral e das resistências ancoradas na memória, no saber-fazer. Tratar sobre a prática da benzedura é desenrolar a meada da recordação: é a lembrança da avó, da mãe e/ou da vizinha, é relembrar cenários, aromas, sabores e gestos.

A benzedura é uma prática muito antiga e, devido a isso, inúmeras vezes acredita-se que não existem mais praticantes nem adeptos do ofício. No entanto, este escrito visa demonstrar que, apesar das perseguições, demonizações, apagamentos e preconceitos que atuam como percalços para a perpetuação da prática, a benzedura ainda hoje está presente de forma ativa no cotidiano de muitos indivíduos, principalmente nos becos e vielas, muito distante dos acessos do centro, mas muito próximo das múltiplas temporalidades de um cotidiano negro. Para além de um conjunto de práticas medicinais e ritualísticas, Elda Rizzo de Oliveira (1985, p. 46) afirma que a benzedura "se apresenta como uma estratégia social e política que as pessoas utilizam na sua vida cotidiana".

O interesse em desenvolver pesquisas sobre estetemase deu, principalmente, pelas lembranças da minha infância, no interior de São Paulo, como filha de 127 Frase comumente dita por benzedeiras durante os rituais. benzedeira. Relembrar esses momentos é sentir novamente o cheiro do ramo de arruda (Ruta graveolens) molhado passando pelo meu rosto para curar alguma inquietação, é resgatar o sabor do chá de chifre de carneiro torrado que minha mãe preparava quando eu ou meus irmãos ficávamos desconfiados ${ }^{128}$, e também o cheiro da arruda flambada na cachaça cujo líquido era bebido pela minha irmã no último dia do resguardo, para que saíssem as "reimas" do pós-parto. Os métodos de minha mãe para diagnosticar os males também eram diversos. Um deles, ainda hoje muito comum, é lamber a testa dos filhos e netos, pois caso o suor esteja muito salgado, é diagnosticado o mau-olhado.

Por essas dádivas vividas, este escrito dialoga muito com a escrevivência, conceito forjado por Conceição Evaristo (2007), porque parto daquilo que experienciei para dialogar com experiências múltiplas, mas também comuns, que são enredadas pela benzedura. Ele também se materializa para relatar esse fazer ancestral que compõe e recompõe modos de vida e existência no município de Pelotas/RS, apontando as práticas que pavimentaram o caminho da sobrevivência e da melhoria da condição de vida de inúmeros indivíduos. Para tanto, este escrito gingará entre os estudos de acontecimentos históricos e os relatos contemporâneos da benzedura, olhará para nossas histórias do passado para que entendamos o presente e vislumbremos futuros, e revisitará, também, a travessia. Este movimento igualmente permitirá compreender a profundidade da prática, que é banhada por um acúmulo de sentidos, percepções, conhecimentos e rituais ancorados em memórias e fazeres que se mantêm pulsantes nas encruzilhadas do tempo.

A benzedura em Pelotas/RS

Pelotas é um município localizado na região Sul do estado do Rio Grande do Sul, sendo um dos mais populosos do estado e com expressiva população negra. Para compreender a importância da benzedura nesta localidade se faz necessário resgatar o contexto em que a mesma se manifestava no passado. 0 intuito aqui não é refazer o percurso histórico, mas pontuar um aspecto que demonstra as camadas e temporalidades desta prática. De acordo com Vitor Monteiro (2016, p. 18):

128 "Desconfiado" se remete aos sintomas que uma criança apresenta por ter uma vontade negada, como a impossibilidade de comer algum alimento ou um brinquedo. É associado também à ascaridíase (vermes). São comuns sintomas como diarreia, inchaço na barriga, vômito e abatimento/tristeza. 
O sistema escravista em Pelotas esteve diretamente associado à produção do charque. A cidade se edificou através das mãos de trabalhadores escravizados e constituiu, no decorrer do século XIX, um dos maiores contingentes de escravos da Província do Rio Grande de São Pedro.

Ainda dentro do referido período histórico e referência espacial, é importante examinar a condição de saúde-doença dos escravizados neste município durante o período colonial. Beatriz Loner, Lorena Gill e Micaele Sheer (2012) afirmam que, através da análise dos Livros de Registro dos Internamentos do Hospital da Santa Casa de Misericórdia de Pelotas/RS referente ao período entre 1870 e 1880, doenças como tuberculose, bronquite e pneumonia eram muito comuns, em especial pela condição climática da região. E também doenças no sistema digestivo, como diarreia, varíola, febre tifoide, além de maus tratos, carências alimentares, desgastes físicos, traumatismos e ferimentos. De acordo com as autoras, devido também ao alto custo dos tratamentos médicos durante esse período e o desinteresse dos senhores de engenho em oferecer o mínimo de condição de vida aos escravizados, grande parte dos padecimentos eram tratados através de rituais das tradições africanas, marcados, principalmente, pelo uso de ervas e encantamentos (LONER; GILL; SHEER, 2012). Desta forma, podem-se constatar traços do que hoje se entende por benzedura, como fruto de um conhecimento ancestral, que resistiu à travessia, que garantiu a sobrevivência de muitos, mesmo quando as ondas do Atlântico arrebentavam nos porões dos navios negreiros, ditando novos ritmos de vida para aqueles povos.

Pelotas, devido a todas as histórias que a constrói, foi chão de muitos rearranjos de negritudes que buscavam se reconstruir e reorientar. Considerando esse aspecto, busquei entender como se dava a prática de benzedura na cidade, me dedicando a pesquisar sobre benzedeiras, benzidos, os elementos utilizados, as doenças tratadas e a espacialidade da benzedura

A forma mais viável encontrada para acessar essas pessoas foi no "boca a boca": sempre que encontrava alguém, principalmente pessoas mais velhas, perguntava se elas já haviam sido benzidas e se conheciam alguma praticante, e dessa forma fui traçando, mapeando e chegando até essas pessoas, essas histórias e essas memórias. Dentre as muitas constatações ocorridas, uma das que se destacaram foi a localização. Estes atores da prática localizavam-se nas áreas mais periféricas ${ }^{129} \mathrm{da}$ cidade, em bairros tanto de fácil quanto de difícil acesso ao centro, como Vila Castilho, Navegantes, Vila Princesa, Santa Terezinha, Vila da Palha e Santos Dumont. A representação abaixo demonstra a localização aproximada de algumas benzedeiras negras que habitam a zona urbana de Pelotas:

Mapa 01 - Localização das benzedeiras negras na cidade de Pelotas

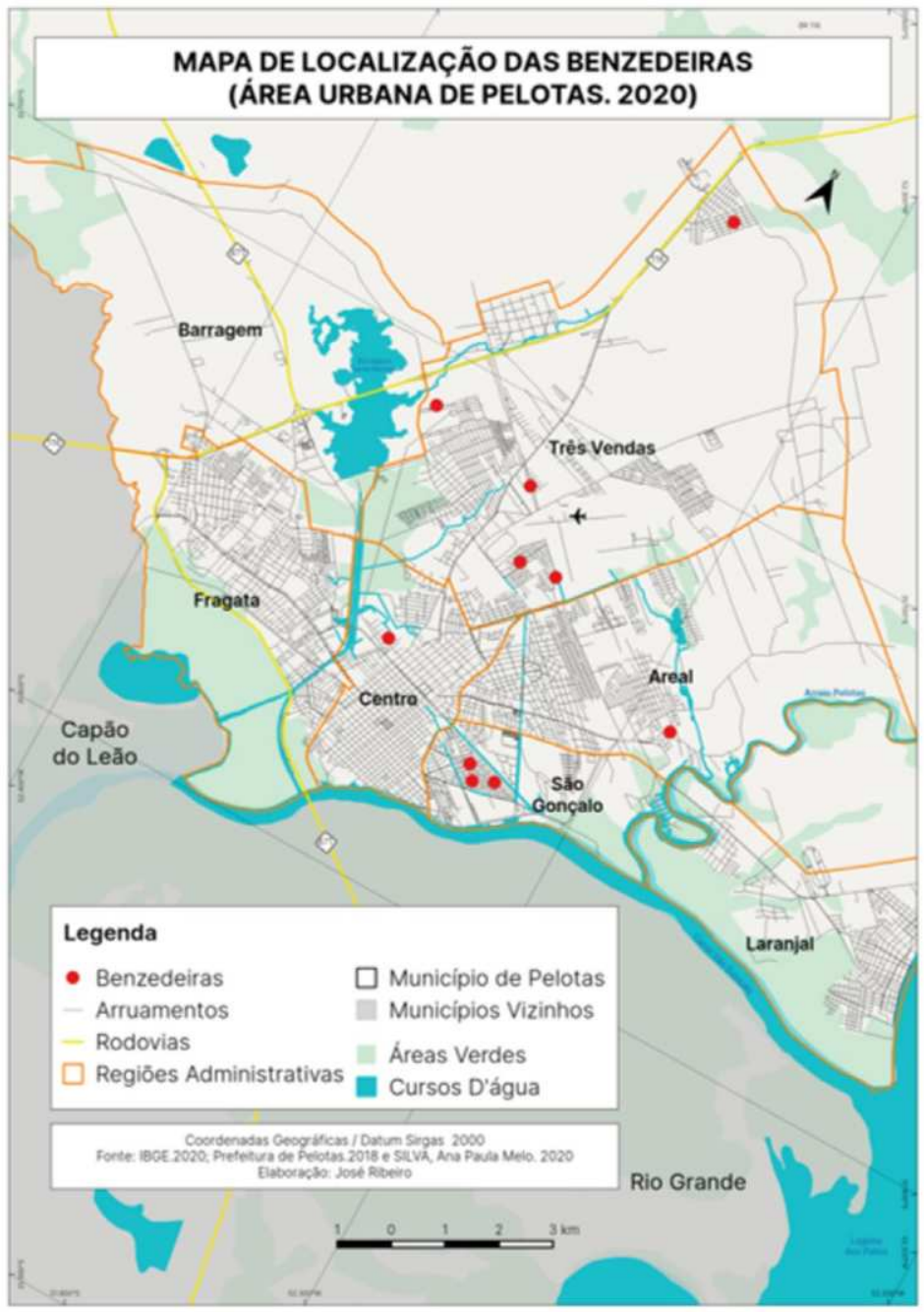

Fonte: elaborado pela autora, 2020

129 Neste trabalho o conceito de periferia não estará atrelado à lógica de centralidade e marginalidade, mas na concepc̃̃o desta enquanto espaço de relações, identificaç̃es e resistências sociais, ancorada de, mas na concepção desta enquanto espaço de relaçoes, identificaçôes e resistências sociais, ancorad talidades que ocorrem nele. 
Uma representação cartográfica traz consigo inúmeras limitações, ainda mais quando se trata de representar espaços compostos por subjetividades naturais e sobrenaturais. No entanto, o mapa apresentado acima se dispõe a demonstrar a disposição espacial destas benzedeiras e reafirmar suas presenças sem limitar a fluidez da prática que exercem. Sabe-se também que este mapa não dá conta de representar a presença de todas as praticantes, visto que muitas já não exercem o ofício por questões de idade, saúde, perseguição ou cansaço - já que este, por vezes, exige dedicação integral - ou por benzerem somente familiares.

Outro aspecto necessário a ser citado se refere à religião das praticantes. Em um dos estudos feitos (SILVA, 2019) ficou evidente a pluralidade e ramificações das crenças religiosas das benzedeiras, sendo elas, principalmente, umbandistas, espíritas, católicas ou não delimitando uma religião. Estudos diversos sobre essa prática apontam que existem duas motivações para a iniciação na benzedura, sendo uma delas a transmissão geracional, quando uma benzedeira iniciante inaugura, incorpora e edifica sua prática mediada pela presença de uma benzedeira já experiente, sendo muito comum esta ser sua mãe. A outra iniciação se dá por uma experiência mística, quando após uma visão, sonho ou situação traumática, a escolhida descobre seu dom, sendo direcionada por uma entidade sobrenatural ou uma inspiração sobre como executar os rituais (ARAUJO, 2011). No entanto, Gill e Rocha (2015) apontam que em Pelotas há uma motivação complementar para se iniciar na práticade benzer: a religião; nesta situação, os sistemas de crença de matriz africana, como a umbanda e o batuque. Isso implica em um panteão diverso nos rituais e também nos espaços em que estes ocorrem, não sendo somente a casa da praticante ou de seu paciente, mas tembém nas terreiras.

0 apontamento anterior possibilita compreender uma característica muito comum na benzedura na cidade de Pelotas: as diversas divindades para as quais são feitas as súplicas e dedicadas as curas, como Xangô, São Cipriano, Iemanjá, Jesus Cristo, Nossa Senhora Aparecida, entre outros. Essas variações correspondem à identidade de cada praticante, podendo haver variações como dedicar todos os rituais a uma mesma entidade - que ocorre principalmente quando a benzedeira é devota desta ou recebeu seu dom através dela - ou associar as divindades o tratamento de doenças específicas (SILVA, 2019)
"Afrodinamicamente mantendo nossa honra viva"130

Para aprofundar a compreensão sobre a benzedura é necessário entender algumas das estratégias para a sobrevivência dessas práticas. Portanto, serão abordadas algumas delas, como a ancestralidade, a memória, a oralidade e outras concepções fundamentais para compreender a estruturação desta prática. É importante reportar aqui como esses fatores estão presentes em todo o processo da benzedura, da aprendizagem à finalização do ritual, do repasse do conhecimento até a constatação da cura. Não apenas estão presentes, mas também asseguram e viabilizam a continuidade da prática e do grupo.

Debruçar-se sobre a benzedura é, inevitavelmente, observar de perto os entremeios e alinhavos da ancestralidade. Esta é entendida enquanto "o eterno impulso inaugural da força de continuidade do grupo", sendo, então, a origem e o destino (SODRÉ, 1988, p. 153). Considera-se também que a ancestralidade não se restringe a laços consanguíneos, mas regula e orienta as práticas e representações do grupo. A mesma não somente rege os ritos, mas orienta também as relações sociais, atuando enquanto princípio regulador (OLIVEIRA, 2007). Adilbênia Machado (2014, p. 57) afirma que a ancestralidade se manifesta "como guia, referência, lógica que organiza".

Em um contexto de escravidão, em que a imposição da travessia resultou em indivíduos escravizados sobreviventes, dentre tantos outros fatos, como a solidão territorial, linguística, afetiva, social, a perda de seus pares, filhos, família, de seus nomes, suas referências, a proibição do culto às suas divindades, assim como a fragmentação de suas identidades étnicas, a ancestralidade atuou como um elo que possibilitou a, mesmo que limitada, reestruturação de alguns alicerces fundamentais para a sobrevivência em outra conjuntura e que estão, ainda hoje, latentes.

Assim, quando os africanos chegaram ao Brasil, o primeiro exercício de sobrevivência foi tentar recompor o tecido cultural africano. Recolheram seus vestígios, seus traços, seus fragmentos e tentaram reelaborar, recompor a cultura do seu lugar de origem, o lugar mãe. Fora a ancestralidade que permeou e sustentou essa tentativa, pois o sentimento materno nos acompanha em todos os lugares. Essa busca da re-territorialização encontra-se no culto à tradição, assim como na possibilidade de continuidade do seu espaço e seu tempo histórico, tempo esse que é o dos ancestrais (MACHADO, 2014, p. 57).

130 MC'S. Racionais. Voz Ativa. São Paulo: Zimbabwe, 1992. 
Dessa forma, pensar a ancestralidade e a benzedura é pensar o ofício de muitas mulheres negras, geralmente idosas e iletradas (SILVA, 2017), que atuam como repositórios vivos, que armazenam, organizam, atualizam e disseminam práticas e conhecimentos múltiplos. Todos esses processos são possíveis, principalmente, por dois fatores de extrema importância: a memória e a oralidade.

Aos que sobreviveram à travessia, aos que foram deixados do outro lado do oceano, assim como os que não sobreviveram fisicamente a ela, e até mesmo aos que nasceram em outra terra devido ao movimento diaspórico, a memória foi e ainda é fundamental. 0 acesso a ela, de maneira consciente ou inconsciente, possibilitou a recriação de modos de vida, a reaproximação com os conhecimentos ancestrais, a busca por uma regeneração identitária e a perpetuação de traços culturais.

A memória e transmissão dos antepassados enraizaram nas terras brasileiras os corpos, os gestos, as palavras, os olhares. Os paladares, aromas, cores, fazeres, saberes. Plantios, alimentos, condimentos. Ritmos, melodias, timbres. Quinas de visão e partes de perspectivas, sagrados, pulsares. Pulos, pernadas, marés, curas, naturezas. Mundos. A bagagem: seus corpos. 0 hoje: a memória. A sabedoria: suas (r)existências. A história: referências de nossas noções do passado. 0 olhar para o passado constró a história que correu pelos caminhos das marés. (TRINDADE; BERRUEZO; SILVA, 2015, p. 65).

Tão importante quanto compreender a memória, é entender como essa se mantém e se movimenta no grupo. Esse acesso e circulação de memórias se deu, e ainda se dá, principalmente pela oralidade. De acordo com Araújo (2016, p. 261), "A oralidade é, para além de um veículo transmissor, a estrutura social, cíclica e antirreligare (pois não há desligamentos) dos povos africanos com os seus ancestrais, e, concomitantemente, com todo o legado transmitido e perpetuado ao longo das gerações". Além do contexto histórico apresentado, é necessário apontar que estas memórias possibilitam a perpetuação da benzedura. É através delas que o conhecimento é preservado, bem como transmitido, absorvido e praticado, através de narrativas, cantos, fórmulas e sentenças, num processo contínuo e infindável, mantendo um ciclo que é vital (ARAUJO, 2016). Na compreensão da importância da oralidade é necessário pensar sua manifestação também na palavra, na voz e no silêncio, estes muito presentes nos rituais.
0 fato de a voz, embora inaudível perdurar nas gerações, esta passa a estar presente, antes de tudo na coletividade, na memória do povo, nas entranhas da sociedade, pois, para a tradição das rezas populares é a maneira mais elementar de compartilhar os saberes e os ensinamentos da comunidade. (NASCIMENTO, 2010, p. 25).

Ainda na perspectiva dos conhecimentos aplicados, pode-se utilizar as contribuições de Muniz Sodré (1988), cujo trabalho permite compreender que na lógica espacial negro-africana a presença do corpo é indispensável, no entanto este não age sozinho, podendo interagir com objetos e demais recursos. Nessa perspectiva de utilização grande é a pluralidade de elementos, que remete então à concepção que se tem da natureza nas culturas ancoradas na ancestralidade, em que a terra, as águas, e as espécies animais e vegetais são os símbolos da ancestralidade africana (SODRÉ, 1988), não ocorrendo, então, o afastamento desses elementos visto que faz-se parte deles.

Pensar essas lógicas nas relações é pensá-las também espacialmente. Muniz Sodré (2017) afirma que, na contramão de culturas ocidentais hegemônicas que valorizam o tempo, nas culturas orientais não-hegemônicas o espaço é a categoria central. De acordo com o autor, as doenças mais comuns entre os escravizados eram desencadeadas pela saudade, em especial, pela saudade do (seu) espaço (SODRÉ, 2017). Sendo assim, uma forma comumente utilizada de suicídio era comer terra até a morte. 0 autor associa isso ao intenso vazio espacial sentido e vivenciado de forma penosa e profunda por estes indivíduos. A mesma análise nos conduz a outro aspecto necessário a ser considerado: o uso do espaço, em especial o espaço da religiosidade, como modo de busca pela continuidade dos modos de vida e de pensamento (SODRÉ, 2017)

Esse espaço tratado aqui não necessariamente se refere somente aos de culto ou templos: ele é também o espaço da casa da benzedeira, é o lar do benzido, a beira do riacho, a horta do quintal que fornece a cura e o alimento, o espaço da mata e da cachoeira, é a árvore onde ocorrem as práticas. É o espaço do ritual. E, tão imprescindível quanto o espaço, são os elementos utilizados e que compõem a ritualística. Elementos como ramos, tesoura, tecido, velas, ovo, linha, faca, fogo, cinzas, água, saliva, sal, mel, vinagre, alho, carvão, formiga, entre outros, integram o arranjo curativo para diversos males. Alguns usos destes elementos serão descritos abaixo para que seus empregos sejam compreendidos. No entanto, ressalta-se que a 
descrição feita aqui não finda as inúmeras possibilidades de utilização dos mesmos, que se diversifica de acordo com as características da praticante e a ritualística própria desenvolvida por ela.

\section{"Eu, como devoto, trago um cesto de alegrias de quintal"131}

A benzedura não pode ser tratada e anunciada como uma prática fixa, com regras delimitadas ou rituais universais. Esta é uma prática descontínua, polidirecional. Ela também tem suas camadas construídas pela relação com outros sistemas e culturas, em especial negras, indígenas e até europeias. Reduzir a prática a um único prisma é abordar com miopia todas as influências que a nutrem e configuram sua pluralidade. Além dessas influências, como já salientado, cada praticante desenvolve seu dom de uma maneira, e suas experiências irão reger a forma como executa os rituais, os elementos que serão utilizados, as divindades com as quais tem proximidade e até mesmo a nomenclatura das doenças e males. Outro aspecto a ser destacado é que o espaço em que está inserida também é fundamental na construção da prática e da identidade da praticante, como as espécies de fauna e flora que fazem parte de determinado bioma, o acesso à água, etc.

Osmaisvariados modos de produzir bênçãos implicam formas diferenciadas de saber-fazer esse ato, às vezes um ofício. Implicam diferentes maneiras de atualizar a memória desse ato e a visão do mundo que o sustenta e o produz. E de produzir, na singularidade de cada ato, as diferentes falas sociais. (OLIVEIRA, 1985, p. 15).

Ao andar pelas ruas, travessas e vielas de Pelotas, bem como observar nos quintais, calçadas, beiras de estrada, jardins e vasos, é muito comum se deparar com diversas plantas de usos medicinais e ritualísticos. Reportando um panorama histórico, a relação com espécies vegetais diversas experienciada pelos primeiros grupos negros a chegarem ao país estabeleceu-se através de articulações e negociações culturais. Os encantamentos memorizados permitiam o acesso à reminiscência dos empregos das plantas ritualísticas e medicinais. E apesar da impossibilidade de acesso à maioria das plantas que eram comumente utilizadas no continente africano, esses povos souberam se adaptar às espécies vegetais nativas 131 GIL, Gilberto. Palco. Rio de Janeiro: Warner, 1981. da nova terra, através da troca de conhecimentos com populações indígenas, assim como introduzir em seus acervos a utilização de espécies até então exóticas, trazidas de outras regiões do planeta pelos colonizadores (CAMARGO, 2006).

Nei Lopes (2007), em seu escrito "Bantos, Índios, Ancestralidade e Meio Ambiente", aborda a questão das interações sob um aspecto muito relevante. De acordo com as afirmações do autor, a relação que os negros, principalmente de origem Banto, estabeleciam com a natureza e a concepção de ancestralidade possibilitou um eco com as ideias de indígenas pindorâmicos. "Segundo a tradição dos povos Bantos, por princípio toda terra é sacralizada - até mesmo uma terra estrangeira [...]" (LOPES, 2007, p. 197), e essa sacralização se estende aos rios, às árvores, à terra, às plantas e aos ventos, justamente porque, de alguma forma, esses elementos serviram aos antepassados, hoje ancestrais (LOPES, 2007).

Foi de posse de crenças e tradições assim estruturadas que os Bantos aqui escravizados encontraram os donos originais da terra, agora, brasileira. Deste encontro, uma atitude geral de deferência e reverência gerou alianças que atravessavam as fronteiras simbólicas (LOPES, 2007). Essas alianças geravam, também, a troca de experiências ecológicas, o que, de acordo com o autor, muito se refletia no uso de plantas, fato que dialoga diretamente com os apontamentos trazidos no presente escrito. Conforme afirmado por Nei Lopes (2007), os povos negros africanos respeitaram, colheram e reprocessaram as concepções indígenas sobre natureza e ancestralidade, bem como repassaram as suas próprias concepções e estabeleceram trocas que foram fundamentais para sua sobrevivência nestas terras.

Retornando o olhar para Pelotas, pode-se notar diferentes usos de uma mesma espécie vegetal. Entre as de uso medicinal tem-se, por exemplo, hortelã (Mentha spicata), poejo (Mentha pulegium), anis-estrelado (Illicium verum), funcho (Foeniculum vulgare), hibisco (Hibiscus), capim-cidreira (Cymbopogon citratus), eucalipto (Eucalyptus), babosa (Aloe Vera), mamona (Ricinus communis), em que o uso se aplica principalmente contra gripes, resfriados, má digestão, expectoração, cicatrização, ação anti-inflamatória, laxante, entre outras tantas indicações. Outros usos comuns estão relacionados às arvores frutíferas, facilmente encontradas na cidade, como laranjeiras, goiabeiras, araucárias, amoreiras, pitangueiras, jambolões, limoeiros, abacateiros, figueiras, em que tanto os frutos quanto as folhas e cascas são utilizados nos preparos. Como, por exemplo, mascar folha de abacateiro para 
tratar aftas, e o uso de folhas de araucária cozidas para tratar tumores causados por distúrbios linfáticos. Além destes propósitos, estas também podem ser o espaço onde ocorrem os rituais (ALMEIDA, 2015), como uma das benzeduras para impingem, que deve ser feita de frente para uma laranjeira.

Outras espécies facilmente encontradas na cidade são comumente utilizadas em rituais. Em especial nos de proteção, são usadas guiné (Petivea alliacea), alecrim (Rosmarinus officinalis), arruda (Ruta graveolens), espada-de-são-jorge (Dracaena trifasciata), manjericão (Ocimum basilicum), entre outras, empregadas contra inveja, mau-olhado, enguiço, energias negativas, etc. Por vezes estes vegetais também são empregados para os gestos durante o ritual, como fazer o sinal da cruz no corpo do benzido com um ramo ou colocá-lo em um copo d'água para obter um diagnóstico sobre qual mal aflige o necessitado e o estágio em que este se encontra.

Sobre estes empregos, Nascimento (2010, p. 80) afirma que: "O ramo, nessa perspectiva, não é qualquer planta, é um instrumento que possui uma carga significativa voltada para o mundo mágico onde lhe é depositada uma força suficiente para retirar o mal". Um exemplo dessa afirmação pode ser observado na benzedura para mau-olhado, em que a praticante utiliza um ramo para benzer o necessitado. Caso o ramo se apresente extremamente murcho após ser passado pelo corpo do benzido, significa que o necessitado estava muito "carregado", mas também que o mal passou para a planta. Após a finalização da benzedura o vegetal deve ser colocado para fora de casa, por vezes sendo descartado no quintal, enterrado ou jogado no telhado.

Ainda no trato do mau-olhado, outro ritual muito interessante se refere ao uso do carvão: utilizam-se de três deles em brasa, juntamente com um copo d'água. A benzedeira, após passá-los próximo ao corpo do enfermo, os imerge em água: se afundarem e, em seguida, boiarem é sinal que a pessoa está "limpa", caso permaneçam no fundo do copo conclui-se que a pessoa está com mau-olhado, então, feito este diagnóstico e constatado o mal, utiliza-se um ramo e uma tesoura. Com o ramo se faz a benzedura e, em seguida, a tesoura é manipulada fazendo movimento de corte repetidamente ao redor do corpo, simbolizando que o mal está sendo cortado da pessoa. Este ritual é repetido três vezes por semana, até que a pessoa esteja livre da mazela.

0 uso de facas e tesouras é comumente observado nos rituais, tanto em Pelotas quanto em outras localidades. Esses dois elementos, quando alocados em um novo sistema, nesse caso a benzedura, desenvolvem finalidades para além do simples uso comum. As facas e tesouras nos rituais simbolizam e executam o corte, o rompimento, o cessar do mal, é o talhar para evitar o avanço.

Partindo tanto das pesquisas que desenvolvi quanto hidratando o estudo por outras fontes (ALMEIDA, 2015; GILL, 2015) foi possível compreender que alguns dos males que são mais tratados por benzedeiras em Pelotas são as doenças respiratórias, como bronquite, sinusite, rinite, pneumonia, entre outras. Estas doenças são comuns devido às características meteorológicas da região, que estimulam e/ou agravam as patologias. Um fato interessante sobre as práticas de cura nestes casos é que existem benzedeiras no município que são especialistas em tratar estes males, e isto ocorre das mais diversas formas.

Em um dos rituais narrados (SILVA, 2019), a entrevistada conta que no tratamento para asma e bronquite que presenciou, um prego era fincado em uma cerca de madeira exatamente na altura da criança enferma, e conforme se dava seu crescimento, ultrapassando a altura marcada pelo prego, a doença era gradativamente curada. Outro ritual para a cura da bronquite através da benzedura se refere à utilização de pedras, em que a cliente é solicitada a levar nove destas Durante o ritual, a benzedeira as segura em suas mãos enquanto faz o sinal da cruz no tórax de quem está sendo benzido. Em seguida, a praticante adentra um cômodo isolado e retorna com um chá, que deve ser ingerido naquele momento Para a eficácia, esse tratamento deve ser repetido durante sete sextas-feiras. Para demonstrar a pluralidade da prática, outro tratamento para bronquite se utiliza de lesmas. Nele a benzedeira desliza o animal no peito e no tórax do enfermo, geralmente criança, que em seguida ingere um chá de figueira branca (Ficus). Essa prática parte da ideia de que a gosma da lesma é a mesma que se encontra no pulmão da pessoa, sendo assim, ela absorve aquele muco que causa a doença. 0 ritual deve ser repetido durante três sextas-feiras não chuvosas, preferencialmente sendo uma delas a sexta-feira santa (GILL, 2015). Outro ponto interessante deste caso é que a comunidade ao entorno se mobiliza também, juntando lesmas para a benzedeira porque reconhece que a procura pela prática aumenta muito durante a Semana Santa ${ }^{132}$, inclusive com pessoas se deslocando de outros municípios para serem benzidas, e essa intensa procura se dá por acreditarem que o período intensifica e potencializa a possibilidade de cura.

132 Celebração da tradição religiosa cristã sobre a paixão, morte e ressurreição de Jesus Cristo, referente ao período entre o Domingo de Ramos e a Páscoa. 
O tecido, a linha e a agulha também são muito utilizados nas benzeduras na cidade, especialmente em rituais para mau jeito, rendidura, quebraduras, machucaduras, carne triada, junta desconjuntada, nervo rendido, que na medicina sintética pode ser considerado como um estiramento muscular, torção, etc. Através destes elementos é feito o ritual de coser, quando a benzedeira costura o tecido, simbolizando a retomada da união entre carne, osso e nervo, devolvendo, assim, a ordem àquilo que está "desalinhado". Neste ritual é característico também um diálogo entre benzedeira e benzida, em que a primeira pergunta "o que é que eu coso?" e a segunda responde "carne triada, nervo rendido", e após segue-se com a reza, que é ritmada pela costura. Tanto nos trabalhos de campo realizados quanto nas conversas bibliográficas (SILVA, 2019 e ALMEIDA, 2015), é possível observar a pluralidade de fins que o tecido pode ter ao fim da benzedura, como ser jogado no telhado, enterrado em um cupinzeiro ou arremessado em um corpo d'água, como córrego, rio ou lagoa.

Outros elementos comuns da benzedura que atuam direta ou indiretamente no ritual são a Lua, o Sol, a terra, o vento, o fogo e as estrelas. Exemplos dos seus usos, que aparecem nas narrativas, são a importância de benzer sempre voltado em direção ao Sol; e também a concepção de que a intensidade da dor sofre variação de acordo com a fase da Lua, fase esta que pode influenciar na eficácia da benzedura. 0 vento é capaz de transportar situações ruins, como feitiços e doenças; a exposição ao Sol ou ao sereno pode causar fortes dores de cabeça; e, por fim, o fogo, que é capaz de causar doenças (MINAYO, 1988). É comum também a utilização da terra para enterrar os substratos dos rituais, como ramos e tecidos. 0 emprego das estrelas é observado, principalmente, para a cura de verrugas, em que em uma noite de céu estrelado devese escolher a mais brilhante delas e realizar a benzedura abaixo da mesma.

É impossível finalizar essa abordagem sobre espaços e elementos e não tratar sobre a água, a água que compõe o chá, o escalda-pé, o banho, o soro, a água doce, a água salgada, a água da chuva, a água quente, a água congelada, a saliva. Esse elemento está presente em diferentes partes do ritual, desde o diagnóstico do adoecimento até aquilo que será indicado para fazer após o termino da benzedura. A água está presente em inúmeros sistemas de crença, sendo considerada um elemento sagrado. Ela é empregada tanto pela sua capacidade de cura e alívio quanto pela crença de que nela o mal não tem forças, principalmente quando simbolizada pelo mar, pela sua imensidão e profundidade (ELIADE, 2001), e nas águas correntes, pela capacidade de carregar aquilo que não é bom. Essa mesma contemplação sobre a água pode ser aplicada ao município de Pelotas, considerando-se a simbologia de três influentes corpos d'água relacionados a três orixás, sendo o Arroio Santa Bárbara - Iansã, o Arroio Pelotas - Oxum e a Laguna dos Patos - Iemanjá, expondo trechos da cosmopercepção africana que se manifestam no contexto, no cotidiano e na consagração dos afluentes do município (AVILA, 2011).

Embora descritas múltiplas formas de benzer para um mesmo mal, apontase que existe um traço comum em todos os rituais. Todos esses procedimentos relatados são acompanhados de uma jaculatória, em que as palavras são ditas de forma muito rápida e num volume extremamente baixo, um cochicho ritmado, impossibilitando a compreensão do que é oralizado naquele momento. E isso, por vezes, se dá pela crença que proferir algumas rezas em voz alta faz com elas percam sua força, ou seja, seu poder. Há também a súplica ou a dedicação da cura para as divindades que compõem a crença da praticante.

Por esses apontamentos é interessante ressaltar o quanto a benzedura está próxima das realidades populares, pela facilidade de acesso aos elementos que compõem o enxoval de cura, pela nomenclatura compreensível dos males, pela linguagem utilizada e pelo contato afetuoso com a praticante. Aqui também se ressalta a adaptação da prática em espaços diferentes, com o uso de espécies endêmicas de fauna e flora, dialogando diretamente com o contexto em que se manifesta, correspondendo, também, aos corpos, identidades e necessidades apresentadas por seus atores.

“De hora em hora, a vida amióra"133

Dentre os objetivos desta breve escrita estava o anseio em demonstrar que a benzedura ainda se faz muito presente em Pelotas. Salientar - incansável e intencionalmente - a tradição de casarões, monumentos e charqueadas soterra inúmeras formas de viver e de (re)compor a negritude, porque demarca constantemente um lugar de sofrimento, folcloriza nossas práticas, nos afasta do que nos manteve vivos. Essa escrita também se dá pela crença na benzedura

133 Essa frase era o mantra, a profecia e o encantamento de minha avó, dona Celeste. Mulher de encantamentos, curas e sabedorias, e que, segundo minha mãe, dona Fátima, que tem as mesmas características, tinha cheiro de doce de goiaba.
ches, 
como recurso político, terapêutico e emancipatório que viabiliza caminhos de sobrevivência, melhoria da condição de vida, bem como reaproxima os indivíduos da cosmopercepção africana ${ }^{134}$.

Outro ponto a ser sublinhado aqui é a importância e necessidade da retomada dessas práticas para que se possamos vislumbrar futuros. Um indivíduo negro curado é um indivíduo negro vivo, isso se refere à construção de nossa ancestralidade em vida e a continuação de nossas práticas e memórias. Temos os remédios e alimentos em nossos quintais, calçadas e ruas, mas morremos doentes e com fome, porque nosso entendimento por vezes se alinha ao que não nos pertence (URASSE, 2020). Recentralizar nossa experiência, reorientar nossa concepção e nossa atenção para aquilo que foi, e é, construído pelos nossos é reassumir nossos conhecimentos sobre alimentação, cura e melhoria da condição de vida. É fazer o movimento de Sankofa "Nunca é tarde para voltar e apanhar o que ficou atrás. Símbolo da sabedoria de aprender com o passado para construir o futuro." Provérbio Akan (NASCIMENTO; GÁ, 2009, p. 40-41). Este escrito, então, também pode ser interpretado como um registro, uma orientação para que retomemos nossos recursos ancestrais de diagnóstico, de cura, de alimentação, de relação com a natureza, com o ser humano e com nós mesmos.

Por fim, ressalto que, apesar das muitas referências acadêmicas presentes aqui, as mais belas, reais e necessárias referências se deram no contato com os que se disponibilizaram a partilhar suas experiências e, junto comigo, colocar em constelação as narrativas, memórias, mistérios e oralidades que não caberiam nos engessamentos acadêmicos, mas que se considerados mudam rumos, perspectivas e viveres.

\section{Referências}

ALMEIDA, Paula Castro. A palavra é que voga: concepções de cura e saúde entre benzedeiras no Município de Pelotas. 2015. 127 f. Dissertação (Mestrado em Antropologia) - Instituto de Ciências Humanas, Universidade Federal de Pelotas, Pelotas, 2015.

ARAÚJO, Fabiano Lucena. Representações de doença e cura no contexto da prática popular da medicina: estudo de caso sobre uma benzedeira. Caos -Revista Eletrônica de Ciências Sociais, v.2, n. 18, p. 81 97, set. 2011.

ARAÚJO, Leandro Alves de. As marcas da diáspora negra na oralidade do candomblé baiano. Revista de Estudos Linguísticos, Literários, Culturais e da Contemporaneidade, n. especial 18b, p.259-264, mar. 2016.

134 "Cosmopercepção" é utilizado de acordo com a tradução do termo "world-sense", concebido por Oyèrónkẹ Oyěwùmí (1997, p. 2-3). Segundo a autora, o uso da terminologia "cosmovisão" é uma prática de supervalorização da visão em detrimento dos demais sentidos, comumente constatada no pensamento ocidental.
AVILA, Carla Silva de. A princesa batuqueira: etnografia sobre a interface entre omovimento negro e as religiões de matriz africana em Pelotas/RS. 2011. 403f. Dissertação (Mestrado em Ciências Humanas) - Universidade Federal de Pelotas, Pelotas, 2011.

CAMARGO, Maria Thereza Lemos de Arruda. Os poderes das plantas sagradas numa abordagem etnofarmacobotânica. Revista do Museu de Arqueologia e Etnologia, São Paulo, n. 15-16, p. 395-410, 2006 .

ELIADE, Mircea. 0 sagrado e o profano: a essência das religiões. São Paulo: Martins Fontes, 2001.

EVARISTO, Conceição. Da grafia-desenho de minha mãe, um dos lugares de nascimento de minha escrita. In: Alexandre, Marcos A. (org.). Representações performáticas brasileiras: teorias, práticas e suas interfaces. Belo Horizonte: Mazza Edições, p. 16-21, 2007.

GILL, Lorena Almeida; ROCHA, Lóren. Trajetórias de benzedores negros ao sul do Brasil. In: GILL, Lorena Almeida; SCHEER, Micaele Irene (orgs.). À beira da extinção: memórias de trabalhadores cujos ofícios estão em vias de desaparecer. Pelotas: UFPel, 2015. p. 101-111.

LONER, Beatriz Ana; GILL, Lorena Almeida; SCHEER, Micaele Irene. Enfermidade e morte: os escravos na cidade de Pelotas, 1870-1880.Hist. cienc. Saúde - Manguinhos, Rio de Janeiro, v 19, supl. 1, p. 133-152, Dec. 2012. Disponível em: http://www.scielo.br/scielo.php?script=sci_ arttext\&pid=S0104-59702012000500008

\&lng=en\&nrm=iso. Acesso em: 7 jul. 2020.

LOPES, Nei. Bantos, Índios, Ancestralidade e Meio Ambiente. In: NASCIMENTO, Elisa Larkin. (org). Guerreiras de Natureza: mulher negra, religiosidade e ambiente. São Paulo: Selo Negro, 2008.

MACHADO, Adilbênia Freire. Ancestralidade e Encantamento como Inspirações Formativas: filosofia africana mediando a história e cultura africana e afro-brasileira. 2014. 240f. Dissertação (Mestrado em Educação) - Faculdade de Educação, Universidade Federal da Bahia, Salvador, 2014.

MINAYO, Maria Cecília de Souza. Saúde-doença: uma concepção popular da etiologia. Cadernos de Saúde Pública, Rio de Janeiro, v. 4, n. 4, p. 363-381, dez. 1988.

MONTEIRO, Victor Gomes. Uma arqueologia das paisagens da escravidão na cidade de Pelotas, Rio Grande do Sul (1832-1850). 2016. 218f. Dissertação (Mestrado em Antropologia com ênfase em Arqueologia)- Programa de Pós-Graduação em Antropologia, Instituto de Ciências Humanas, Universidade Federal de Pelotas, Pelotas, 2016.

NASCIMENTO, Danielle Gomes do. Tradições Discursivas Orais: mudanças e permanências nas rezas de cura e benzeduras populares da região de Itabaiana.2010. 157 f. Dissertação (Mestrado em Linguística e ensino) - Universidade Federal da Paraíba, João Pessoa, 2010.

NASCIMENTO, Elisa Larkin; GÁ, Luiz Carlos (orgs). Adikra: sabedoria em símbolos africanos.Rio de Janeiro: Pallas, 2009.

OLIVEIRA, Eduardo David de. Filosofia da ancestralidade: corpo e mito na filosofia da educação brasileira. Curitiba: Popular, 2007

OLIVEIRA, Elda Rizzo. 0 que é benzeção. São Paulo: Brasiliense, 1985.

OYĚWÙMÍ, Oyèrónke Visualizing the Body: Western Theories And African Subjects. In: OYĚWÙMÍ, Oyèrónke. The Invention of Women: Makingan African sense of western gender discourses. Minneapolis: University of Minnesota Press, 1997.p. 1-30. Tradução para uso didático de Wanderson Minneapolis: Univer
Flor do Nascimento.

SANTOS, Milton. Por Uma Outra Globalização: do pensamento único à consciência universal. Rio de Janeiro: Record, 2001 
SILVA, Ana Paula Melo da. Benzedeiras Negras: na benzedura a ressignificação da solidão e na busca pela cura a manifestação do amor. 2017. Trabalho de Conclusão de Curso (Licenciatura em Geografia) Instituto de Ciências Humanas, Universidade Federal de Pelotas, Pelotas,2017.

SILVA, Ana Paula Melo da. Na Encruzilhada das Práticas e Memórias Negras:Benzedura e ancestralidade no município de Pelotas-RS. 2019. 137f Dissertação (Mestrado em Geografia) - Programa de PósGraduaç̃̃o em Geografia, Instituto de Ciências Humanas, Universidade Federal de Pelotas. Pelotas, 2019

SODRÉ, Muniz. O Espaço da África no Brasil. Interpretações da Cultura. 2017 (16 min.51s). Disponível em: https://www.youtube.com/watch?v=8asUpAkFbu4. Acesso em: 13 jul. 2020.

\section{SODRÉ, Muniz. 0 Terreiro e a Cidade: a forma social negro-brasileira. Vozes, 1988.}

TRINDADE, Camila Sousa; BERRUEZo, Luna Borges; SILVA, Otávio Bontempo Nunes. Ensino e Aprendizagem das Culturas Afro-brasileiras: epistemologias e documentação cultural. Revista Ciência em Extensão, v.11, n.1, p.63-84, 2015. Disponível em: https://ojs.unesp.br/index.php/revista_proex/ article/view/956. Acesso em: 09 jul. 2020.

URASSE, Anin. Ciência e Tecnologia Ancestral Preta. III Colóquio Afrofuturista. 2020. (2h. 53min. 16s) Disponível em: https://www.youtube.com/watch?v=XkENeeacWVk Acesso em: 24 jul. 2020

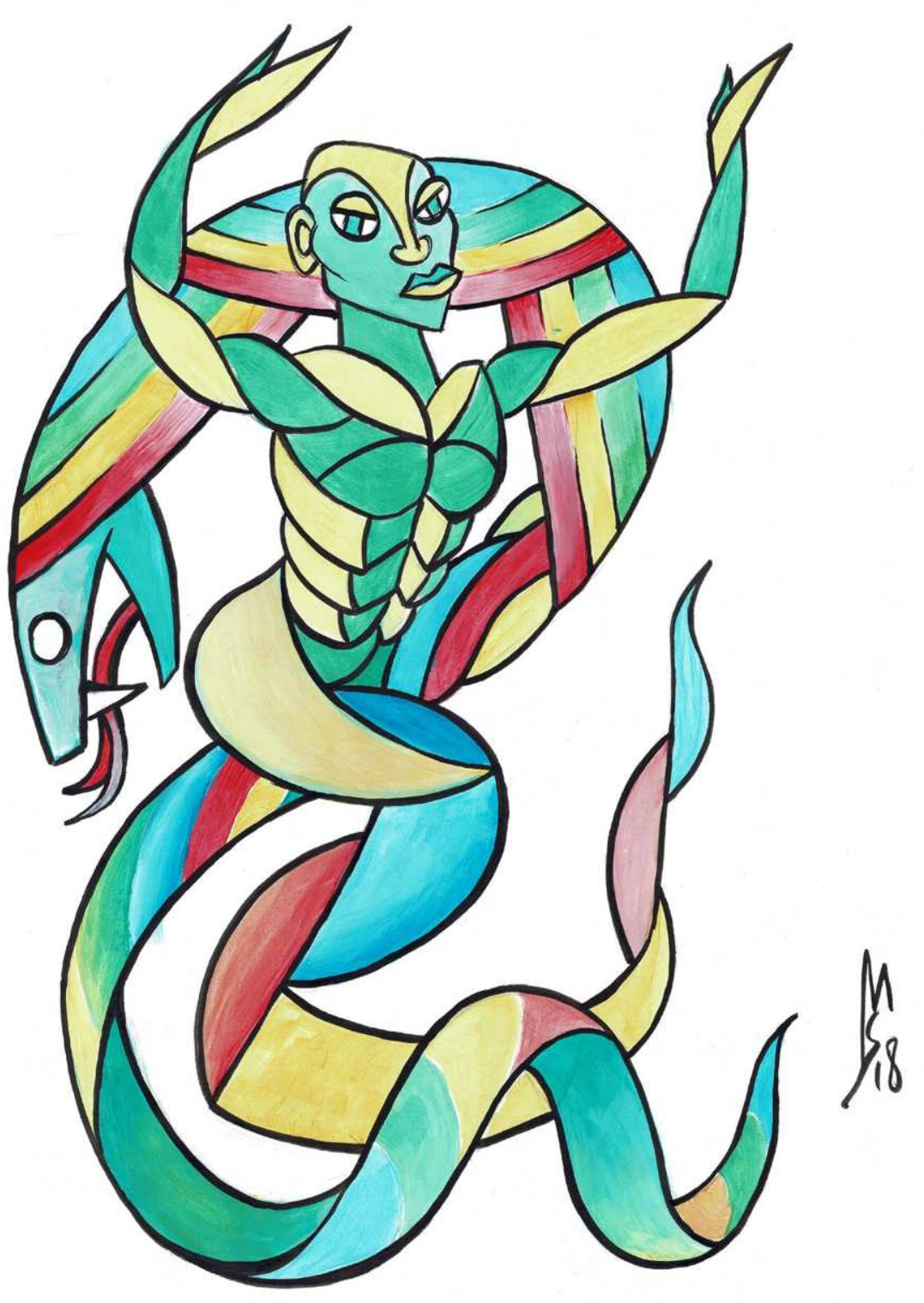




\section{MÃE SEVERINA: ENTRE TERRITÓRIO E TENDA NOSSA SENHORA DOS NAVEGANTES, TERRITÓRIO QUILOMBOLA SANTA ROSA DOS PRETOS (ITAPECURU-MIRIM/MA)}

Dayanne da Silva Santos ${ }^{136}$

\section{Òșùmàrè̀ ${ }^{135}$}

Peço licença para falar; Licença as/aos mais velhas/os Licença aos ancestrais/encantados

Foto 01: Mãe Severina abrindo o terreiro em festa/noites de obrigação na Tenda Nossa Senhora dos Navegantes.

Òrișà ninu ilé - aquele que é do interior da terra ao lado de Șànpọnná - Obàlúaiyé.

Ambos vinculados ao mistério da morte e do renascimento.

$$
\text { Arco-íris, Òșùmàrè. }
$$

Aquele que é multiplicidade da vida.

Que está ligado ao cordão umbilical e à placenta.

Círculo infinito de início, meio, início, meio...

Serpente que se enrosca engolindo a cauda.

$$
\text { Serpente mítica. }
$$

Levanta-se das profundezas da terra

atinge o firmamento

e volta a penetrar a terra. Ciclo vital!

Vida em movimento.

Mobilidade.

Continuidade da existência.

Ritmo da vida no Cosmos.

Oríkì (louvacão) para Òșùmàrè, construído a partir das obras: “Agadá: dinâmica da civilização africano-brasileira", de Marco Aurélio Luz (2000); "Os Nàgô e a Morte: Pàde, Àsèsè e o culto Égun na Bahia”, de Juana Elbein dos Santos (2012); e “Dicionário yorubá-português”, de José Beniste (2011).

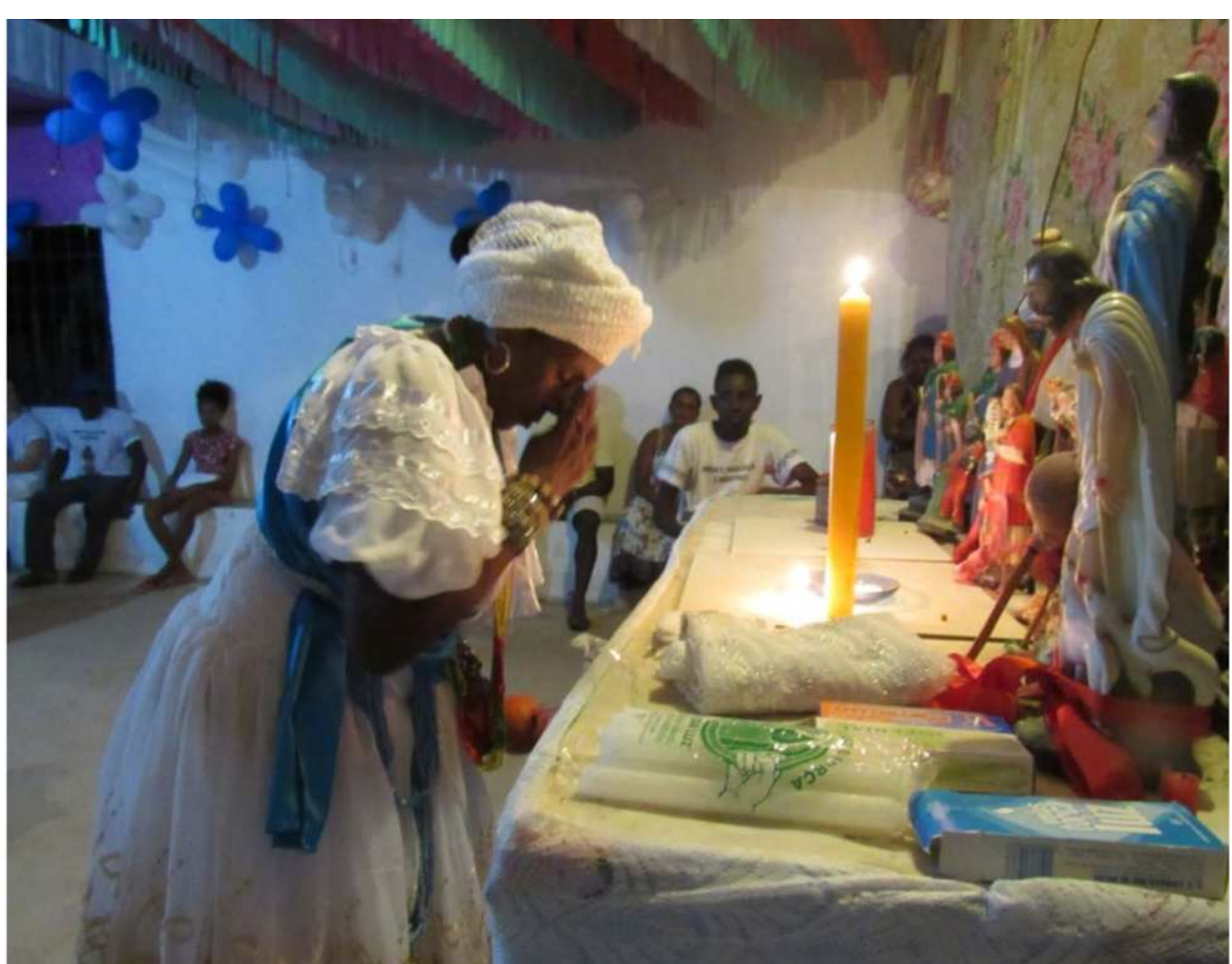

Fonte: Arquivo pessoal.

136 Mulher negra, ativista, periférica e de terreiro. Doutoranda do programa de Pós-Graduação em Sociologia da UFRCS e integrante do Grupo de Estudos: Desenvolvimento, Modernidade e Meio Ambiente (GEDMMA/UFMA) - e-mail: lavignedayanne@gmail.com 


\section{Introdução}

Este manuscrito traz narrativas sobre o Tambor de Mina ${ }^{137}$, a partir de pesquisas empíricas e de uma escuta analítica sobre a experiência e história de vida de uma mulher negra, quilombola e mãe de santo,Dona Severina. As narrativas contidas aqui fazem parte da dissertação defendida em 2019 junto ao Programa de Pós-Graduação em Ciências Sociais da Universidade Federal do Maranhão (UFMA) e contou com apoio dos projetos de pesquisas ${ }^{138}$ financiados pela FAPEMA e CNPQ sobre conflitos ambientais e territoriais no Maranhão junto com o grupo de pesquisadores do Grupo de Estudos: Desenvolvimento, Modernidade e Meio Ambiente (GEDMMA/UFMA).

Desde novembro de 2014 estamos acompanhando sistematicamente o território quilombola Santa Rosa dos Pretos ${ }^{139}$, localizado ás margens do Rio Itapecuru no município de Itapecuru-Mirim no Estado do Maranhão. Este trabalho é um ponto de partida para entender arelação entre mulher negra, religiosidade e natureza. A partir do lugar de protagonismo de mulheres negras na luta política pelo território. Sendo mais precisa, fui levada em campo a pensar a encantaria ${ }^{140}$ como uma modalidade de pensamento e prática cotidiana que amplia o debate sobre a problemática fundiária de não titulação de terras quilombolas.

É quando tomamos os encantados ${ }^{141}$ como os verdadeiros donos da terra que abrimos um leque de possibilidades para que percebamos o mundo e as relações sociais através do entendimento de que entidades espirituais formam o território $137 \quad$ Usaremos no decorrer do texto, a palavra Mina para nos referir ao Tambor de Mina. E mineira ou

mineiro para nos referirmos aquelas pessoas que fazem parte da Mina.
138 Dos projetos de pesquisa "Mineração, Territórios e Desigualdades Ambientais no Brasil: diversidade sociocultural e luta por direitos" (CNPQ/FAPEMA) e Projetos de Desenvolvimento, Mineração e Comunidades Negras no Maranhão: fronteiras territoriais, lutas sociais e afirmação de direitos (FAPEMA/CNPQ) ambos ligados ao Grupo de Estudos: Desenvolvimento, Modernidade e Meio Ambiente (GEDMMA-UFMA). 139 "Faz limite com outros territórios e quilombos. Ao leste, com o Rio Itapecuru e o quilombo Filipa. A oeste, com o território quilombola Monge-Belo (território este bastante presente junto ao território Santa Rosa, nas mobilizaçoes e enfretamentos, perante o capital, por suas garantias de direitos). Ao norte, com as te quilombo Oiteirodos Nogueirs" (SIVA, 2017 p. 49) "É um grande território ná Fuisombola, com 20 quilombos dentro, sendo que existe um quilombo dentro desse território com o mesmo nome. 0 teritón composto por uma grande e rica rede de parentesco que são marcados pelos casamentos e apadrinhamo é Também uma categoria de luta fruto do processo de afirmação e valorizac̃a de uma identidade negra que tem. como forta 140 Usaremos a noção de encantaria proposta por Mundicarmo Ferretti (2000, p.108). Segundo a autora as encantarias geralmente são concebidas como mundos situados no fundo das águas, dentro das árvores, ou abaixo da terra (em outro planeta). O lugar onde habitam as entidades (voduns, gentis,caboclos e outros). ou abaixo da terra (em outro planeta). O lugar onde habitam as entidades (voduns, gentis,caboclos e outros). surupiras, guias e espíritos de luz. Bem como o fazem no território quilombola estudado. com uma cosmopolítica afro-brasileira (ANJOS, 2001), que nos ajuda a entender os sentidos outros para a existência da pessoa negra, no caso estudado, da mulher negra, quilombola e de terreiro.

Assim, destacamos que, o culto aos encantados é uma dimensão de consciência importante para conferir forma aos modos de resistência/enfrentamento aos conflitos ambientais e aos problemas de não titulação das comunidades quilombolas no Brasil.

A relação entre pessoas e encantados como forma de coproteção da natureza é o princípio filosófico que se destaca das práticas existenciais do culto que estamos estudando e que tem como uma de suas expressões o respeito (categoria êmica). Por esse princípio, é possível dizer que quando a pessoa deixa de proteger o território, ela também perde proteção cósmica para si e para o seu próprio corpo. 0 respeito é fundamental ás relações sociais e religiosas dentro do território, ele vai desde o ato de tomar benção às/os mais velhas/os, a circulação ou não em determinadas áreas de mata, consideradas dentro do território como sagradas, assim como o simples ato de colher uma folha, tudo isso perpassa uma licença prévia pautada no respeito aos ensinamentos recebidos pela sabedoria ancestral e pelos encantados. Nesse contexto, a natureza aqui é composta por corpos que são plurais, e se fazem existir em redes extensas de cuidados e afetos.

Nesse sentido, este texto desdobra questionamentos sobre como o corpo quilombola e a natureza estão vinculados pelos encantados, tendo em vista que o território negro estudado se encontra fatiado/danificado pelo avanço desde os anos 1940, década de significativo desenvolvimento econômico (ferrovias, linhões de energias, rodovias e fazendas). Desde 2005, lideranças quilombolas do território estão pressionando o Instituto Nacional de Col onização e Reforma Agrária (INCRA) e as demais instituições responsáveis pela titulação de terras quilombolas no estado do Maranhão, a fim de alcançarem sua cidadania, território livre.

Os dados obtidos durante a pesquisa foram coletados a partir de pesquisa etnográfica; com a realização de entrevistas semiestruturadas, observação, revisão bibliográfica e pesquisa de campo. Durante o período, foram feitas cerca de vinte entrevistas que envolveram desde mães, filhas de santo e lideranças quilombolas á entidades espirituais, incorporadas em médiuns. Mesmo já estando engajada em pesquisas no território desde 2014, junto ao GEDMMA, somente intensifiquei o 
exercício da realização e estruturação das entrevistas entre os anos de 2017-2019, no processo de elaboração da dissertação. As entrevistas/conversas foram colhidas e cedida sem diversos momentos e espaços dentro do território, como por exemplo, casas, cozinhas, quartos, quintais, roças, igreja, terreiro, dentre outros.

Foi acompanhando mãe Severina e seus fazeres, assim como de outras mulheres, em diferentes espaços e tempos, que conseguimos reunir um conjunto de entendimentos, por vezes complexos, sobre o Tambor de Mina e sobre a força dos encantados na vida no território.

Acompanhando um território atravessado por megaprojetos de desenvolvimento, que rasgam os tecidos comunitários dos mais familiares aos mais coletivos, que compartilhamos aqui uma escrita plural, de mulheres negras que resistem e lutam pela vida diariamente. Nessa situação de violência, as "conversas" passam a figurar como "dados" importantes da pesquisa nas argumentações sobre a construção/manutenção do corpo em conexão com os encantados. Assim, inúmeras foram às situações de "conversas" até a elaboração final da dissertação, que nos possibilitam hoje fazer recortes/aprofundamentos sobre uma reflexão de corpo/ território por meio da experiência de mãe Severina, uma de nossas principais interlocutoras na pesquisa.

Por isso, escolhi as narrativas da Mãe Severina e de suas filhas de santo, assim como dos encantados do território quilombola Santa Rosa dos Pretos como fio condutor de uma perspectiva orientada em uma filosofia que emana do terreiro, entendido como território de pessoas e encantados. Os relatos, os encontros, as visitas, as festas/obrigações não apenas me ajudaram na compreensão da luta da comunidade, como também foram basilares para o aprofundamento/ampliamento da análise e compreensão sobre a noção de "pessoa" e "natureza" quando acionados em contexto de territórios negros.

Com a permissão de cada pessoa e encantado optei em manter os nomes das nossas/os interlocutores para assegurar uma coerente caracterização do nosso campo de pesquisa, bem como para mostrar a importância de cada pessoa e encantado nesse processo, pois, acreditamos que sem seus pensamentos, conhecimentos e conversas essa escrita/pesquisa não seria possível. As pessoas e os encantados dão forma a escrita, ao trabalho como um todo, pois, apesar das experiências individuais de aprendizagem durante as pesquisas de campo, este é um texto coletivo, tecido pelas conversas e escutas das mais externas: as audiências públicas, manifestações, participação em eventos/seminários na universidade; as mais familiares: as conversas das cozinhas, quintais e interior da Tenda, antes, durante e depois da vinda de um encantado.

Tenda e obrigações

"A Mina não é ABC Não é uma escola que se apreende a ler"

Doutrina cantada por caboclo Tupinamba (Tenda de Mãe Severina -Itapecuru-Mirim/MA)

Para a leitura desse texto três pontos são importantes. Primeiro: este trabalho é fruto das nossas observações de campo,é, acima de tudo, resultadoda observação direta (in loco) e de uma escuta diária. Segundo: as compreensões, definições e os conceitos sobre pessoa, natureza, território e encantados que norteiam nossa escrita emanam primeiro das concepções e das formas de entendimento das pessoas incorporadas de si mesmas, das pessoas incorporadas por alguma entidade e dos encantados com os quais conversamos. Terceiro: este trabalho não se prende a conceitos e formas de enquadramento, pois, como disse caboclo Tupinambá, "a Mina não é A, B, C, não é uma escola que se apreende a ler", e apesar de todas as contribuições etnográficas que nos permitem visualizar as diferentes formas pelas quais a encantaria se apresenta na Pajelança, Terecô e no Tambor de Mina, queremos pontuar que nem os pais/mães de santo sabem de fato de onde as entidades vêm. A Mina é um mistério, e são os mistérios e segredos que tornam a encantaria um território existencial (GOLDMAN 2003). Assim, a encantaria da Tenda de mãe Severina não é a mesma de outro terreiro, "cada casa tem seu fundamento e seu asè, por isso, a Mina é Mina, um grande mistério" (Mineirinho, encantado, em novembro de 2018).

Nesse sentido, tomamos o território quilombola e a encantaria como mundos que estão em conexão um com o outro e reexistem por meio do compartilhamento de múltiplas experiências, acordos e trocas entre pessoas e pessoas, pessoas e encantados e encantados e encantados. Uma rede extensa de sociabilidade. 
Dessa forma, podemos afirmar que é construído, pois, a mata, que é morada dos encantados dentro do território, também é um lugar de exercício da política, haja vista que dentro dela se firmam acordos, lutas e resistência.Nesse contexto, buscamos entender todo um modo de ser que é passado de geração a geração através da cultura, dos encantados, dos mais velhos, da memória, da fala, das trocas, das religiões, dos tambores, de costumes que vão tecendo uma rede de relações entre pessoas e encantados no processo constante de permanência no território quilombola.

A Tenda Nossa Senhora dos Navegantes de mãe Severina existe há mais de 35 anos, sendo chefiada pelas entidades: seu Cearense e dona Tereza Légua. Mãe Severina tem 66 anos de idade e há mais 45 anos dança Mina.

$\mathrm{Na}$ Tenda Nossa Senhora dos Navegantes acontece um total de cinco festas Durante todo o ano. A primeira festa/obrigação ocorre no mês de fevereiro, em duas noites, é feita para seu João Guará e São Lázaro - com a mesa para os cachorros ${ }^{142}$. A segunda festa ocorreem abril, uma de noite, chamadadentro do quilombo de Aleluinha, em homenagem a dona Dodô Légua, irmã mais nova de dona Tereza Légua. A terceira acontece em agosto, para seu Cearense. Dessas festas, somente na festa de seu Cearensesefaz obrigaçãopara mães d'águas na Matinha (lugar sagrado).A obrigação na Matinha acontece no primeiro dia de festa, das três noites de festas em sua homenagem. Em todas as outras festas tem toque para mães d'águas dentro da Tenda.

A quarta festa ocorreem setembro, para o caboclo seu Pedro Légua. Segundo mãe Severina, na festa do velho Pedro não se faz obrigação com tambor para as mães d'águas na Matinha, mas se limpa e coloca luz, a obrigação acontece dentro da Tenda. Na festa de seu Pedro Légua se festejam São Cosme e Damião, santos católicos.Seu Pedro costuma sempre jogar muitos bombons no chão da Tenda como na parte de fora, esse é um dos momentos bem divertido para a criançada, sendo que ainda tem adultos que caem sobre as crianças (brincando) para também juntar bombom no chão. Aqui o encantado festeja os santos, é uma grande alegria.

O pessoal da comunidade diz quea festa de seu Pedro Légua vale por três noites de festas, apesar de ocorrer apenas em uma noite. Isso por conta da quantidade de pessoas que participam da festa e das extensas atividades, principalmente de preparação das comidas, que requer semanasde organização e preparo. Apesar de forma de agradecer e homenagear o santo católico São Lázaro. a festa acontecer somente em um dia e uma noite, Dona Dalva ${ }^{143}$ se prepara o ano todo para que a festa aconteça, sempre com a ajuda do seu guia (Pedro Légua) e amigos e parentes. Aqui pessoas e encantados trabalham juntos para que as festas/ obrigações aconteçam nas datas previstas.

A quinta festa da Tenda, aniversário de dona Tereza Légua acontece durante 3 noites em dezembro, agora nos dias 28, 29 e 30. Até em 2017 a festa acontecia nos dias 29, 30 e 31 de dezembro, sendo uma das principais festas no território. Essa festa reunia muitas pessoas, principalmente no dia 31/12, na virada de ano. Segundo seu "Budega" "antes quase não se tinha festas aqui por perto, hoje é quem mais que tem uma radiola, é quem mais que faz festa aqui” (anotações do caderno de campo de dezembro de 2017). A festa de dona Tereza Légua ainda reúne muitas pessoas, tanto do território como de outros lugares próximos, mas não como antes, a maioria das pessoas que participam da festa são a convite de dona Severina ou de dona Tereza Légua, bem como aquelas pessoas que têm obrigação com a Tenda/casa como as/os médiuns, as/os serventes e os abatazeiros ${ }^{144}$.

Dona Tereza Légua nos contou que teve uma vez que ficou tão zangada com Seu Elias e com o finado Sebastião (ambos abatazeiros) que foi embora para junto de seu pai (velho Légua). Mas, ele não demorou amandá-lavoltar para Santa Rosa para cuidar das suas/seus filhas/filhos. Segundo Dona Tereza Légua, seu pai mandou que ela ajoelhasse perto dele, e ela pensou que ele ia pedir para que rezasse, mas não. 0 velho Légua estava com uma vara de espinho de tucum nas mãos e quando perguntou se ela não iria voltar para a sua casa (a Tenda) e ela respondeu que não, bateu nas costas de Dona Tereza que o punhal que prendia seu cabelo caiu e os cabelos dela se soltaram e cobriram todo o seu rosto. Segundo ela,ele batia e dizia,

a mais você volta, porque você enganou o velho Cearense dizendo que ia só passear na croa da menina dele (dona Severina) e resolveu morar lá, até conseguir parte da Tenda/casa e da Matinha. A mais você volta! Você não queria uma casa lá? Agora você vai cuidar dela e de seus filhos (anotações do caderno de campo do dia 02/01/2019).

143 Mulher negra, liderança quilombola, caixeira, rezadeira (e o que mais ela quiser ser) bem como filha de santo de mãe Severina da Tenda Nossa Senhora dos Navegantes. Com ela apreendi muito das ontologias de resistência e de protagonismo das negras dentro e fora do quilombo.
144 "Geralmente são homens e meninos do quilombo que participam na Tenda tocando os tambores, as cabaças e o ferro, bem como do Tambor de Crioula" (SANTOS, 2019, p. 26). 
Das entidades que se manifestam na/os mineiras/os ${ }^{145} \mathrm{em}$ noites de festas na Tenda Nossa Senhora dos Navegantes temos: os caboclos da família de Légua, encantados da família da Turquia/ entidades nobres, voduns, caboclos, surrurpiras, princesas, entidades crianças, entidades da família de Acóssi, pretas/os velhas/os, mães d'águas e pombas giras,além daquelas que nós não conhecemos por nome e que se manifestam na Tenda em noite de festas. Toda vez que falamos de festa aqui é sempre no sentido religioso/obrigação.

Na Tenda Nossa Senhora dos Navegantes, uma família muito importante é a Família do Velho Légua. Segundo mãe Severina,

Eu pra mim, Mina é a mesma Umbanda, o pessoal que lá fora gosta de separar. E a Umbanda é a mesma Mina. E aqui tem muitas pessoas que são da Mina, principalmente da família de Légua, mas não querem se assumir.. olha aqui na festa de seu Cearense tem noite que dá só a família de seu Légua na Tenda, quem mais que carrega eles... é Pedro, Domingas, Antônio, José, Rosa, Maria Assunção, que é a mesma Maria Légua (conversa informal concedida em agosto de 2017).

Em "A família de Légua tá toda na eira: tramas de parentesco nas relações entre pessoas e encantados", Ahlert (2016) analisa as relações entre pessoas e encantados a partir de dois casos nos quais estes seres se cruzam em tramas de parentesco e toma a encantaria como o espaço de referência dos encantados da mata. Assim, ela vai mostrando isso por meio das suas pesquisas com o povo de terreiro/povo de Codó e da família de Légua Boji Buá.

Légua BojiBuá comanda uma importante e numerosa família de encantados que, segundo relatos, somam mais de quinhentas entidades...Venho dizendo que a família mais conhecida em Codó é de Légua BojiBuá da Trindade, encantado que tem pai, irmãos, sobrinhos, esposa, além de grande número de filhos e netos. Seu Zé Preto, um pai de santo da cidade, me disse que Légua é filho de Pedro Angaço e casado com Rosa Rainha, hoje não "carregada” por ninguém em Codó. A grande família de Légua compartilha a relação com a mata, o gosto pela bebida alcoólica (poucas vezes vi algum encantado da família de Légua não beber) (AHLERT, 2016, p. 04).

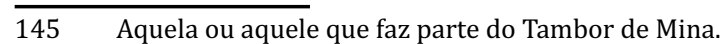

Ainda sobre José Joaquim Boji Légua da Trindade, mais conhecido como "O Velho Légua", rei da encantaria de Codó, sua filha Tereza de Jesus Légua (conhecida como Terezinha Légua) nos disse que,

O nome do meu pai é José Joaquim Boji Légua da Trindade, todos nós temos José no nome e Buá é apelido. Tem muita gente que diz que recebi meu pai, diz, mas não recebi. Meu pai é a coisa mais difícil é ele descer em terra, ele veio agora na minha festa para resolver esse problema com meu irmão Pedro Légua sobre a festa dele. Assim, porque ele estava muito chateado com a gente (pessoas e encantados da Tenda) - meu pai não anda sozinho, ele vai assim com a gente segurando, ele anda devagar. Ele, às vezes dá uma volta no salão e até mesmo para cantar nem todo mundo entende o que ele fala. Seu Elias (abatazeiro guia) ainda entende, pouco mais entende. Até aqui na Tenda Nossa Senhora dos Navegantes meu pai vai vim aqui só no dia 21 de setembro de 2019 na festa do meu irmão Pedro em cima de dona Severina (anotações do caderno de campo do dia 02/01/2019).

Dona Tereza nos relatou isso no dia do fechamento de sua festa. A festa de dona Tereza Légua começou nesse ano no dia 28/12/2018 e foi até o dia 30/12/2018. No dia 28/12/2018 a festa abriu com uma obrigação para as mães d'águas.

O tambor começou cedo por volta das $19 \mathrm{~h} 00$, muitas pessoas estavam presentes na Tenda tanto para dançar como para assistir, incluindo crianças, jovens, adultose idosos. Dona Severina cantou e rezou para abrir sua festa na presença de suas/seus filhas/filhos, abatazeiros, serventes e de seus guias.

Com o maracá ${ }^{146}$ na mão, ela iniciou cantando,

Abereigarapé

Aberei mar

Abereigarapé

Aberei mar

Com essa doutrina para mães d'águas ela segue cantando e sai de frente do altar balançando o maracá e vai benzer os abatazeiros, os tambores, a pedra

146 Instrumento de percussão usado nas obrigações do Tambor de Mina como canal de comunicacão entre as pessoas e os encantados. Um maracá quando feito para muitos não passa de um instrumento musical, mas quando as pessoas são orientadas por seus guias (encantados) a unir sementes, forca (comusas), e mrotec̃ano (cas pessoas são orientadas por seus guias (encantados) a unir sementes, força (codo próprio guia de luz em dias/noites de obrigação. 
de centro ${ }^{147}$ da Tenda. Logo em seguida os mineiros (as/os filhas/os) da Tenda vão dançando em fileira atrás de dona Severina até formar uma roda e continuam dançando e cantando em volta da pedra que fica no centro dentro do salão da Tenda. Severina segue cantando e chamando a linha de mães d'águas. A primeira nessa noite veio em Severina e cantou,

\section{Eu corro, corro, corro \\ Ô mamãe eu vou correr (bis) \\ Ô mamãe eu vou banhar \\ Lá no posso de beber (bis)}

A segunda noite (dia 29 de dezembro de 2019) foi para os caboclos, a Tenda estava cheia.Muitas mineiras e mineiros de outras Tendas se fizeram presentes na festa de dona Tereza Légua, foi uma noite muito bonita. A casa estava cheia de visitantes e as filhas/os da casa quase todas/os estavam presentes. A festa se iniciou com dona Severina doutrinando,

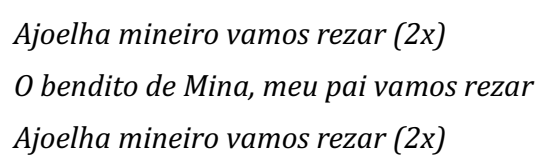

A terceira noite de tambor se encerrou com os parabéns e corte do bolo por volta das $22 \mathrm{~h}$, e não teve um segundo toque de tambor, logo em seguida, como de costume. Assim, o tambor ficou aberto até o dia 02/01/2019. Era por volta das $21 \mathrm{~h}$ quando dona Tereza desceu para fechar o tambor, somente com o toque do maracá. Com as velas acessas sobre o altar e na pedra de centro, na presença de alguns abatazeiros e um filho e uma filha de santo sentadas/os assistindo junto com as demais pessoas a obrigação foi cumprida.

A guia da casa, dona Francisca (irmã de sangue de Severina) cuidou de defumar o salão. Dona Tereza doutrinou para fechar o Tambor. Logo em seguida, todos que estavam no salão, nessa noite de obrigação, tomaram água servida em uma grande cuité (bacia) e seguiram para o quartinho da Tenda, tomar 12 cervejas

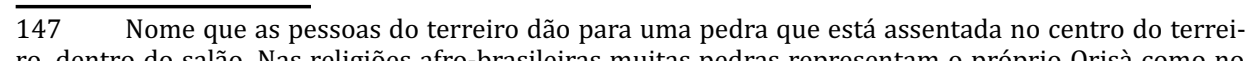
ro, dentro do salão. Nas religiões afro-brasileiras muitas pedras representam o próprio Orisà como no Batuque, no Tambor de Mina esse significado mantém e se amplia para um ponto de força do terreiro e da Tenda) estão sempre cuidando para que sempre se tenha luz sobre ela, velas acesas. com Dona Tereza. Enquanto nós tomávamos as cervejas eu, Lucca, Renata, Elias, dona Francisca, Otaciro (conhecido como Tatá) e Thamara, nossos ouvidos e atenção estavam concentrados em Dona Tereza, que ia nos contando coisas sobre sua vida e a forma como cuida da sua casa/Tenda e de seus filhos/filhas, as/os mineiras/os.

Das/os filhas/os de santo que dançam com frequência na Tenda de mãe Severina, a maioria nasceram no quilombo, exceto, Paulo Ricardo que é de Rosário; Osmar que é de Santa Rita;Edinael que é da sede de Itapecuru-Mirim; Nélio que é de uma comunidade chamada Cachoeira, localizada no município de Itapecuru-Mirim; Lucca que é de Chapadinha e Renata que é de um povoado do município de Santa Rita, chamado Areias.

Os abatazeiros que tocam na Tenda de mãe Severina são todos nascidos e criados em Santa Rosa. São mais de 20 homens e meninos que são tocadores de tambor na/da Tenda. No quilombo são os homens que tocam nas noites de festas dentro da Tenda, mas nos dois últimos anos presenciamos a entrada das meninas no tambor, Fabíola que já tocou o chapanãe cabaças ${ }^{148}$ e Rhianaque já tocou cabaças. Elas sentiram vontade de ir tocar e foram e as pessoas do quilombo ficaram surpresas, mais muito felizes. Elas são netas de dona Marizinha, filha da Tenda Nossa Senhora dos Navegantes, e em dias de festa, Fabíola e Rhiana estão sempre na companhia da vó.

As/os serventes (a maioria são mulheres, mas tem alguns homens) também são fundamentais para que as festas aconteçam, são elas/es que cuidam de todas as coisas do terreiro, deste a limpeza/decoração do salão até preparar e servir as comidas em dias defestas na Tenda de mãe Severina. 0 serviço das/os serventes começa dias antes da festa, principalmente na limpeza da carne que será servida no almoço e no jantar. Tem outras pessoas que também ajudam nas festas, seja doandocomida/alimentos, velas, foguetes ou, até mesmo, dinheiro. Para uma festa acontecer dentro do território se gasta mais de quatro mil reais, só com comida. Por isso, ajuda de amigos, parentes e convidados são importantes. Antes do fatiamento do território para a passagem do desenvolvimento econômico o alimento provinha em grande quantidade das roças, matas e igarapés. Os mais velhos contam relatos de que as mulheres "só se abaixavam, esticavam as barras das saias e pegavam $148 \quad$ Chapanã e as cabaças são instrumentos musicais e de obrigação da Tenda. Chapanã é o nome dado a um dos três tambores de dentro da Tenda. Assim como o maracá são canais de comunicação entre as pessoas e os encantados. "Os instrumentos usados durante as festas são: três tambores (guia, chapanã (SANTOS, 2019, p. 72). 
muitos peixes no velho Igarapé Simauma", hoje é drasticamente danificado pelos empreendimentos, há escassez de alimentos no quilombo.

A Tenda é dividida em 10 espaços:o corredor, dois quartos; quatro espaços (onde as entidades ficam para beber, conversar/orientar e fumar); um quarto (o quarto de segredos) que só dona Severina, Dalva e dona Francisca entram; outro, onde se guardam as comidas e bebidas das festas; e o salão, onde são realizadas as festas. Ou seja, depois do salão, tem uma área de fundo onde ficam alguns tambores no canto e onde os encantados se reúnem, logo em seguida temos um corredor com uma porta de saída de fundo, ainda no corredor do lado direito temos uma área com outra entrada para a Tenda. No terreiro temos três entradas, que são também as mesmas de saída. Em um dos quartos onde as filhas e filhos de santo se arrumam temos uma cama de casal.Seguindo no corredor, temos do lado direito outro quarto (também com cama e usado pelas filhas/filhos de santo) e do lado esquerdo um espaço onde fica algumas roupas de Mina penduradas nas paredes, uma bacia de água na frente (isso em 2015). Hoje,essa área tem um enorme tecido rosa florido em uma de suas paredes (o tecido muda conforme a cor de cada festa) e várias fotografias das festas expostas nas demais paredes que eu tive o cuidado em colocar na Tenda com a permissão da mãe de santo. Deixei também com ela cópia da dissertação, álbuns com as fotos do terreiro e pendrive com os vídeos e fotos da Tenda. Essas foram uma das formas que encontrei para devolver e partilhar o trabalho que eu venho fazendo na Tenda.

Seguindo, no fundo desse cômodo temos um espaço onde dona Severina e seus guias recebem as pessoas para conversar, nesse ambiente encontramos um espelho grande perto da porta, uma mesa decorada com tecidos vermelhos e amarelos. Do outro lado, tem a cadeira de "mãe Severina" decorada com um tecido laranja rendado, outro vermelho e um travesseiro branco para apoiar as costas (em 2015), do lado esquerdo um freezer, no fundo outro altar com algumas imagens de santos, entidades, flores, um quadro de Severina com finado Sebastião. No ano de 2018-2019 esse espaço como foi reformado e ampliado, se abriu um quarto dentro da Tenda para seu João Guará receber suas visitas e fazer seus serviços.

No fundo da tenda tem uma área externa, a área da cozinha, que antes era de taipa (barro molhado, palha e madeira) e hoje é de alvenaria (de tijolos) a reforma se deu com a contribuição das filhas/filhos da Tenda e de amigas/os, parceiros do terreiro. Dentro dessa área tem um espaço reservado para venda de bebidas e danças, de cunho não religioso, durante as festas,no qual seu Budega, (marido de Núbia que é filha de Valéria, que é irmã de sangue de mãe Severina) é responsável pela comercialização das cervejas. As cervejas são consumidas tantos pelos encantados como pelas pessoas que estão na Tenda, mas fora do salão.

A Tenda é um espaçode disciplina, troca e aprendizado. Na entrada da Tenda logo se vêum cercado feito de madeira que circula toda a área do terreno e que tem somente uma entrada, também feita com madeiras. Do lado direito da Tenda tem a casa da mãe de santo (Severina).Já do lado esquerdo tem uma árvore centenária, um Pé de Pequizeiro ${ }^{149}$ que, segundo dona Severina, já saciou a fome de muitas famílias da comunidade.

Hoje, tanto a Tenda como a cozinha da Tenda e a casa da mãe de santo estão pintadas com a cor rosa, que foi a cor da festa do ano de 2018 para seu Cearense. Dentro da Tenda, assim que entramos, podemos visualizar ao fundo do salão o altar. Nele estão dispostas imagens de santos católicos, de entidades do Tambor de Mina, velas, um maracá. Mãe Severina geralmente abre as festas da Tenda na cura ${ }^{150}$, para isso faz uso do maracá que fica disposto no altar, de doutrinas específicas para esse momento em que chama as Mães d'águas, o povo das águas, e depois “vira”, e começa a cantar para o povo da mata, para os caboclos.Na parede,de dentro do Salão, tem um banner de umafotografia de Severina com uma caixeira ${ }^{151}$ da comunidade. Quando as entidades se fazem presente no salão é o altar que elas primeiro "reverenciam", depois a mãe Severina e em seguidas as/os demais filhas/filhos que estão presentes, ou entidades, e quando vão doutrinar, saldam os tambores na figura dos abatazeiros.

O altar da Tenda é composto por várias imagens de santos que foram em boa parte "presentes", inclusive eu leveiuma em nome da professora

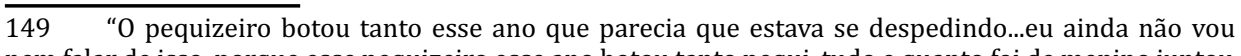
nem falar de isso, porque esse pequizeiro esse ano botou tanto pequi, tudo e quanto foi de menino juntou pequi aqui pra comer, merendar, fazer o lanche, tudinho com farinha, porque, pra quem gosta ele enche barriga. Porque pé de pequi dentro desse quilombo aqui, eu dou essa aqui (ela mostra as mãos) à palmatória se tem, um pequi gostoso como esse aqui. Aí, os caras vêm de lá querendo derribar esse pequizeiro, sem mais nem menos.A não é assim não...quando meu avô se entendeu ele já era pequizeiro, ele vem do tempo do escrave (enruba co pequizeiro, se refere ao processo de duplição da BR-135, que ameaça ao dizer que querem derrubar o pequizeiro, se refere ao processo de duplicação da BR-135, que ameaça

150 A linha de cura é mais praticada em rituais da Umbanda nos quais e manifestam entidades caboclas e Pretos velhos.

151 "Em São Luís e em diversas outras cidades maranhenses, a festa do Divino é estreitamente identificada com as mulheres, e em especial com as mulheres negras ligadas às religiões afro-brasileiras. Esse fato distingue a festa no Maranhão das festas do Divino realizadas em outras regiões do país e lhe dá uma feição bem particular. Informaçôes disponiveis em: <https://www.geled
pirito-santo-no-maranhao-e-suas-caixeiras/> Acesso em: 03/11/2020. 
CíndiaBrustolin ${ }^{152}$,imagem de São Cosme e Damião ${ }^{153}$ —Gaga, abatazeiro, disse que quando nascem gêmeos no quilombo geralmente eles recebem os nomes de Cosme e Damião, ele mesmo recebeu o nome de Damião. 0 salão é quase sempre decorado por mulheres e meninas da comunidade; com balões, tecidos e TNTs ${ }^{154}$, o teto quase não se vê por conta dos movimentos dos tecidos coloridos. Aindadentro da Tenda podemos encontrar os tambores, a pedra de centro e um banco feito de cimento ao redor de todo o salão.0 teto da tenda é todo coberto com tecidos coloridos, que são colocados e tirados pelas serventes.

\section{SEVERINA: a mãe de santo}

Mãe Severina nos contou que cada abatazeiro da Tenda Nossa Senhora dos Navegantes tem uma força da casa, por isso, quando eles vão tocar em outras Tendas, eles estão antes de qualquer coisa representando a Tenda de onde são filhos e mesmo que ela não esteja presente, mas se suas filhas/filhos estiverem, é mesmo como se ela estivesse, sendo ela mãe de santo da casa de onde elas/es são filhas/os.

A viabilidade da pesquisa se deu por conta também do laço de amizade e confiança que fui construindo com as pessoas do quilombo, há mais de cinco anos, principalmente com a mãe de santo Severina e sua filha de santo Dalva. Assim, desde abril de 2015 venho acompanhando as festas de Tambor de Mina naTenda Nossa Senhora dos Navegantes no território quilombola Santa Rosa dos Pretos, a convite da mãe de santo.

Dona Severina é casada com seu Ilário, eles moram em uma casa do lado da Tenda. Seu Ilário, certa noite, nos contou que não é fácil ser casado com uma mãe de santo "a pessoa para se firmar com uma pessoa que é médium tem que ser quieto" (conversa informal realizada em janeiro de 2019). Ser quieto é ter compromisso com sua parceira e acima de tudo, respeito, principalmente para com os acordos firmados com os guias ${ }^{155}$ dela.

152 Foi sob a orientação dela que muita da pesquisa foi possível bem como o deslocamento para o quilombo. Em nome dela agradeço a uma rede extensa de pesquisadores/amigos do GEDMMA e fora dele 153 Entreguei os 153 Entreguei os santos a dona Severina dizendo que era um presente meu, da professora Cíndia e da 154 É um tipo de material classificado como um não tecido. É produzido a partir de

$154 \quad E$ um tipo de material classificado como um não tecido. É produzido a partir de fibras desorientadas que são aglomeradas e fixadas e geralmente custa um real o metro.

Os guias são os encantados como já infonnos, porém aqui nos referimos aos encantados que são donos da cabeça de mãe Severina
Dona Severina se orgulha muito da ajuda de seu Ilário, pois, segundo ela, nas horas em que ela mais precisou, ele estava ali, do lado dela. A relação entre eles é de carinho e respeito para com os guias dela (Severina), que orientam o que podem ou não fazer. Dona Severina nos contou que é mais fácil ser filha de santo do que mãe de santo, no sentido que, para a mãe de santo, o serviço e as obrigações para com as coisas da Mina são dobrados. Por exemplo, em noite de festa/obrigação, mesmo se não tiver nenhum filho na Tenda, ela tem que cumprir com a obrigação. Tem que doutrinar, rezar e acender as velas, nem que seja só ela, seus guias e a força do maracá.

Severina Silva é filha de Maria Domingas Silva (falecida) e Paulo Leonel. 0 pai de dona Severina, seu Paulo Leonel é filho de Benedito Grande (falecido). De família de lavradores, Severina tem duas irmãs, Francisca e Valéria.Ela nasceu e se criou dentro do quilombo, quebrou muito coco babaçu ${ }^{156}$ para ajudar no sustento de casa, fez muito carvão para poder sobreviver,pescou muito no Igarapé Simauma ${ }^{157}$ (igarapé grande), apanhava arroz de meia $^{158} \mathrm{com}$ as pessoas do quilombo Barreira Funda ${ }^{159}$, em quase tudo trabalhou.

Atualmente,é trabalhadora rural aposentada.Seu estudo foi pouco e com 16 anos ela teve um primeiro casamento, aos 17 anos teve uma filha, Maria de Fátima. Seuparto foi feito em casa, por uma parteira chamada dona Francisca (conhecia por Chiquinha) e acompanhado por sua madrinha dona Severina Belfort, que hoje tem 105 anos. Maria de Fátima, hoje com 50 anos, trouxe o seu nome no parto por conta de uma promessa que dona Severina fez à Santa. Quando perguntamos sobre a promessa, ela nos respondeu que é segredo dela com a santa (risos).

Quando sua filha completou três anos, Severina começou a dançar Mina na casa de Georgina ${ }^{160}$ e de seu Pai João Guará (encantado). No inicio seu pai biológico foi contra, mas segundo afirma, nem ele e nem ninguém poderiam tirar sua missão, pois foi algo que trouxe de nascença.

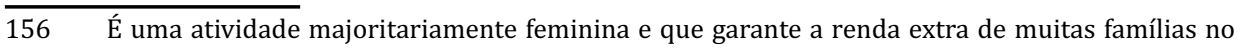
meio rural. Mais informações ver em: https://www.miqcb.org/quem-somos

Esse é um dos principais igarapés do território quilombola. "Nas palavras de Anacleta "água é vida, porque é dele (do igarapé Simauma) que vem grande parte da água que alimenta as roças, os córregos, outros igarapés, abastece as casas e fecunda o terreiro "Assim, a água permitedentre outras coisas, a p.138). Desde os anos de 1980 vem sendo assoreado pela Estrada de Ferro Carajás da empresa Vale S A. p. 138). Desde os anos de 1980 vem sendo assoreado pela Estrada de Ferro Carajás da empresa Vale S.A. 158 Expressão local. "Apanhar arroz de meia - cortar e dividir entre os donos da lavoura o arroz - se 159 uma roça tem dois ou mais donos se corta o arroz no meio para poder dividir" (SANTC situado dentro do território quilombola Santa Rosa dos Pretos.

159 Quilombo situado dentro do território quilombola Santa Rosa dos Pretos. território quilombola. Ele junto com seu Benedito Belfort lutam pelo território desde os anos 50. 
Quando sua filha tinha oito anos de idade (Maria de Fátima), Dona Severina teve outro marido, seu Ilário Pires, que já tinha uma filha, Claudia Regina, essa filha mãeSeverina criou como se fosse sua. Prática que ela repetiu por uma segunda vez, com uma criança que recebeu o nome de Núbia(com 20 dias de nascida). Dona Severina tem como netos: José do Espírito Santo, conhecido por Walison, Lândia de Jesus, Daiane de Jesus, Yasmim de Jesus e Iago de Jesus. Seu Ilário vive com ela até hoje e a família só cresce.

Teve uma época em que dona Severina chegou a morar em Santa Inês ${ }^{161}$,e, estando longe do quilombo, pensou que ia se afastar da Mina. Não precisaria assim mais dançar ou tão pouco incorporar os encantados (pensava ela). Porque, porsua vontade mesmo, ela não dançava, segundo ela: "para quem ver de fora o Tambor de Mina é muita festa, mas para quem está dentro é obrigação, por isso, também eu me mudei do quilombo".

Eu achei que indo pra lá eu não ia dançar Mina, só que eu me enganei. Cheguei até a apanhar do meu patrão (Caboclo Cearense), eu sofri muito e depois a gente se mudou para Itapecuru-Mirim. Aí foi que eu apanhei muito, até enlouquecer, fiquei em uma situação que só vendo para acreditar. Mas lá tinha uma senhora que morava na frente da minha casa, uma pessoa muito querida, ela era mineira só que eu não sabia. Um dia meu pai Cearense me bateu muito, furou meu nariz com um prego, porque, segundo ele, boi bravo se amansava era furando a venta. Ai, ela vendo meu sofrimento falou para meu marido que ela fazia meu trabalho, mas ela nunca tinha feito um trabalho antes, ela disse pra Ilário que ela ia fazer, os guias dela iam ensinar ela a fazer, e ela fez o meu trabalho de croa ${ }^{162}$, graças a Deus! (mãe Severina, entrevista concedida em 20 de abril de 2018)

Foi por conta de dona Damiana (mineira), que fez o trabalho de croa de dona Severina, que ela hoje é mãe de Santo e pode fazer o trabalho de outras filhas/filhos de santo. Ter o trabalho feito significa ter força para conseguir firmar a Tenda e as

161 Município do interior do estado do Maranhão.

162 Uma mãe ou pai de santo com ajuda dos guias vão preparar a filha ou filho de santo para se firmar com seus guias. No trabalho de croa se usar de rezas, velas e cantos, alguns filhos podem ficar até 9 dias deitas em um quaro pelos guias. Mas tem filha/filho que não precisa deitar e pode ir para sua casa mas durante o tempo do trabalho precisa respeitar a a quas regras que são ditas a ela/ele pela mãe/pai de santo ou pelos guias. Um encantado pode ser ao mesmo tempo irmã/o e mãe/pai de santo de outro encantado. Um exemplo, temos a relac̃̃o entre Seu Pedro Légua que é irmão de Dona Tereza Légua mas como mãe Severina com temos a rlaça con irmã como mãe de seu Pedro. Para se fazer um trabalho de croa a pessoa ter conta, ou seja força. obrigações. Uma mãe de santo precisa da força de uma conta ${ }^{163}$ para poder apoiar seus filhos a se firmarem na Mina. Uma conta é uma força.

Depois de fazer o trabalho de Severina, Dona Damiana, por motivos que nem dona Severina nos revelou, sumiu. Segundo Severina, ela disse que depois de fazer o trabalho, elas não poderiam mais estar se encontrando. Assim aconteceu e hoje Severina lembra com saudade e gratidão de dona Damiana. Mãe Severina (entrevista concedida em 20 de abril de 2018), nos falou que: "A gente é mãe de santo é, mas, é assim, morrendo e aprendendo porque nunca a gente sabe das coisas todas".

Dona Severina afirma que já nasceu diferente das outras crianças, já nasceu médium. Desde pequena anda acompanhada por seus guias. Um dia, quando estávamos conversando na porta de sua casa sobre sua infância, nos relatou que,

Quando eu era pequena, andava sempre dentro da mata, e eu gostava. Quando meu avô (Benedito Grande)ia pescar, eu ia com ele. Uma vez, nessas idas, eu vi uma sapa muito grande, e meu avô disse:“menina volta pra cá”. Daíeu cai em febre depois. Na verdade, eu vi uma encantada que era dona do igarapé que meu avô estava disgotando, e eu só melhorei quando meu avô fez remédio pra mim (mãe Severina, entrevista concedida em 20 de abril de 2018).

Dentre as doutrinas para mãe d'águas cantadas na Tenda, temos,

Sou uma Mãe d'água lá do poço de beber (2x)

Lá eu vejo gente

E gente não me vê.

Outra doutrina diz que,

Foi Mãe d'água grande foi quem me ensinou rezar $(2 x)$

Beirei beireigarapé

Beirei beirei beira-mar

Os encantados estão na natureza, são natureza e estão o tempo todo sobre vigilância dentro das matas, águas, folhas e árvores. "Nenhuma pessoa sabe de fato deonde os encantados vêm, mas que eles existem, existem! Eu mesma vi mãe d'água quando era criança em um poço" (Dalva setembro de 2018).

163 Muito resumidamente é ter seu trabalho de/no santo feito - trabalho de croa, ou seja, se iniciar no Tambor de Mina, e só quem têm trabalho feito pode vim a ser pai ou mãe de santo. 
Nem todas as pessoas possuem o dom para ver os encantados. Nesse contexto, várias foram as narrativas que ouvimos de que, em Santa Rosa, existem lugares que nem quem nasceu e se criou no quilombo vai sem a permissão da mãe de santo e dos encantados, como a Matinha, lugar sagrado e morada dos encantados.

\section{Considerações finais}

Nas narrativas cotidianas das pessoas com as quais dialogamos durante esses anos de pesquisa e nos trânsitos/visitas entre Tendas de Tambor de Mina e território quilombola, acompanhando as filhas/filhos e mãe de santo, Dona Severina, que tecemos entendimentos sobre a encantaria como modo de vida, que dá forma a mulher negra, de terreiro, em uma relação de respeito e de cuidado com a natureza, que é entendida como parte da fortaleza do povo quilombola.

A escuta e as conversas fundamentaram uma compreensão mais ampla sobre um existir a partir das ontologias e relações presentes nas narrativas cotidianas de pessoas e encantados. Assim, quando dona Severina e dona Dalva nos colocam que desde pequenas olham, sentem e são orientadas pelos seus guias, elas nos permitem afirmar que,a encantaria é um dom, uma força cotidiana de dimensões múltiplas de consciência. Desta forma, existe uma orientação e um saber presente nas ciências dos encantados, nessa relação que é religiosa, política e familiar se semeia um estudo que se passa/se ensina por meio das doutrinas/pontos, sonhos, intuição,visitas ou em dias de obrigação dentro da Tenda e fora dela.

Falar da Tenda Nossa Senhora dos Navegantes por meio da vida de mãe Severina é falar da luta de todo o quilombo por autonomia, sustentabilidade eterritório livre. Os relatos chamam atenção para prejuízos sociais, físicos e cosmopolíticos: o assoreamento dos igarapés, a derrubada das palmeiras e das mangueiras, a possível derrubada do pé de pequizeiro centenário, os atropelamentos e mortes na rodovia BR/135 (atualmente em vias de duplicação) e na ferrovia, a diminuição das roças para instalação dos linhões de energia e fazendas e a imposição de viver sob um tempo de incertezas e espera.

O tempo de incerteza sobre a titulação das terras negras no Maranhão é acompanhado pelo racismo, que promove dentre tantas coisas, a flexibilização das leis ambientais.
0 Estado brasileiro consegue dar o primeiro passo de uma forma relativamente consistente que é o passo do reconhecimento... mas não consegue dar o segundo passo que é o da titulação das comunidades quilombolas. Então, esse segundo passo é justamente o ponto do maior conflito fundiário do Brasil, nesse momento justamente é onde os interesses raciais se chocam em toda a sua contradição colonial encoberta até aqui (ANJOS, entrevista concedida em 26 de junho de 2018)

Para o antropólogo José Carlos Gomes dos Anjos (2017) “a possibilidade de existir das comunidades negras anda atrelada ao desejo de desfazer o jogo colonial" (conversas de orientação). Nesse sentido, nos interrogamos como construir outras perspectivas sobre as minorias que emanam das religiosidades afro-brasileiras (DOS ANJOS, 2008), cosmovisões que estão presentes, por exemplo, na obrigação para mães d'águas, que conectam múltiplas dimensões de identidades e de natureza.

\section{Referências}

AHLERT, Martina. "A família de Légua tá toda na eira": tramas de parentesco nas relações entre pessoas e encantados. 30 a Reunião Brasileira de Antropologia, realizada entre os dias 03 e 06 de agosto de 2016, João Pessoa/PB. Disponível em: http://evento.abant.org.br/rba/30rba/files/1466467272 ARQUIVO_RBA2016_Completo_AfamiliadeLeguatatodanaeira.pdf. Acesso em: 25/06/2020.

ANJOS, José Carlos Gomes dos. 0 corpo nos rituais de iniciação do Batuque. In: Corpo e significado, ensaios de antropologia social. Porto Alegre: EDUFRGS, 2001

ANJOS, José Carlos Gomes dos. Entrevista concedida em 26 de junho de 2018.

ANJOS, José Carlos Gomes dos. A filosofia política da religiosidade afro-brasileira como patrimônio cultural africano. Debates do NER, Porto Alegre, ano 9, n. 13, p. 77- 96, jan. /jun. 2008.

CARNEIRO, Sueli. Mulheres em movimento. Estudos Avançados 17 (49), p. 117 - 132, 2003.

FERRETTI, Mundicarmo Maria Rocha. Maranhão encantado: Encantaria maranhense e outras histórias. São Luís: UEMA Editora, 2000.

GOLDMAN, MARCIO. Os Tambores dos mortos e os tambores dos vivos. Etnografia, antropologia e política em Ilhéus, Bahia. Revista de Antropologia. São Paulo, USP, 2003. V. 46 no 2. (p. 445-476).

SANTOS, Dayanne da Silva. Não se pode entrar em terra de encantado sem permissão: um estudo sobre a relação entre pessoas e encantados na luta pelo território quilombola Santa Rosa dos Pretos (Itapecuru-Mirim/MA). São Luís/MA, UFMA, 2019 Dissertação do Programa de Pós-Graduação de Ciências Sociais da UFMA.

SILVA, Anacleta Pires da. Resistência e trajetória de luta pela regularização fundiária do território quilombola santa rosa dos pretos. São Luís/MA, UFMA, 2017. Monografia de Graduação do curso de licenciatura em pedagogia da terra pelo organizado pelo PRONERA. 


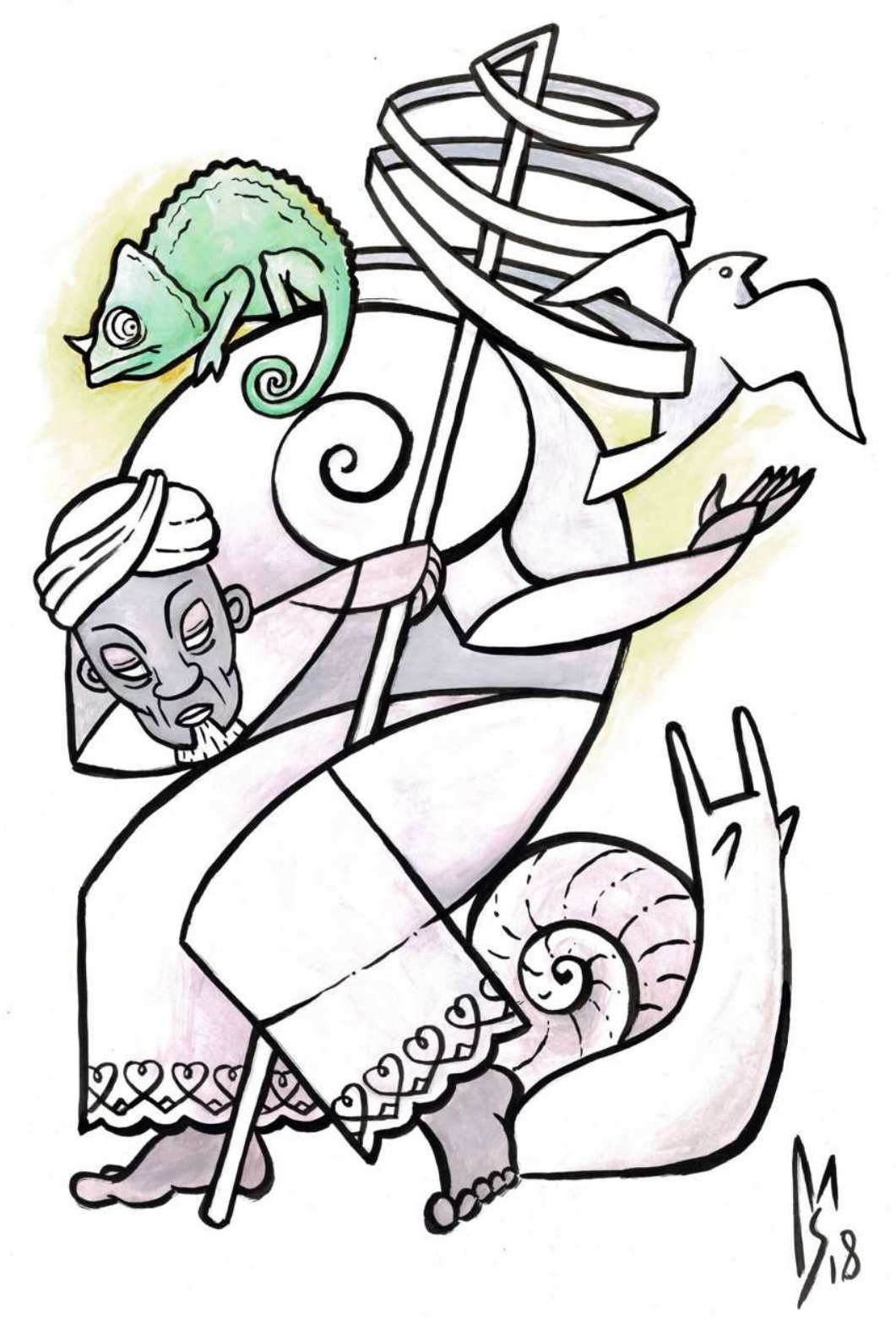

\author{
Òsàllá ${ }^{1}$ \\ 0 mais velho! \\ Começo dos começos, \\ Representa a massa de ar, \\ a massa de águas frias e imóveis \\ do começo do mundo. \\ Águas de Òsàlá! \\ Origem de novas formas de existência \\ nos mundos visível e invisível. \\ Com Òpásóró \\ criou os dois níveis de existência \\ diferenciou o Àiyé do Ờrun. \\ Os dois planos da existência são por ele controlados \\ - dos vivos e dos mortos. \\ òsàlá - Obàtálà, Odùduwà$$
\text { Orìsà Funfun. }
$$ \\ Senhor do pano branco - do àlò \\ Aquele que possui importante relação com as árvores.
}

Oríkì (louvação) para Òșàlá, construído a partir das obras “Os Nàgô e a Morte: Pàde, Àsèsè e o culto Égun na Bahia", de Juana Elbein dos Santos (2012); e "Dicionário yorubá-português", de José Beniste 
Trilhos. Coordena o Coletivo Encontros Marginais, integra o Coletivo Pretambor de Porto Alegre (RS), o Grupo de escritas criativas Suporte (UFRGS) e o LUTA (UFRGS). Tem experiência na área de Ciências Sociais e Sociologia com ênfase em Sociologia Ambiental, atuando principalmente nos seguintes temas: questões ético-raciais, conflitos ambientais, território de povos e comunidades tradicionais, Estado, quilombos, religião de matriz africana. Projetos de desenvolvimento econômico. Deslocamentos compulsório no Maranhão.

E-mail: lavignedayanne@gmail.com Institucional pela Universidade Federal do Rio Grande do Sul na linha de pesquisa: Clínica, Subjetividade e Política. Pesquisador no Núcleo de Estudos e Pesquisas ELÉÉKO pela Universidade Federal de Pelotas e Universidade Federal do Rio Grande do Sul. Experiências como psicólogo jurídico, psicólogo na saúde mental e atenção psicossocial e psicólogo clínico onde realizo atendimentos individuais, supervisão de práticas e táticas profissionais, aquilombamentos desde grupos de estudos articulados às temáticas das relações raciais e psicoterapias de grupo.

E-mail: psi.ademieljunior@gmail.com

\section{Ana Paula Melo da Silva}

Licenciada e Mestra em Geografia pela Universidade Federal de Pelotas (UFPel). Pesquisadora do Núcleo de Estudos e Pesquisa É́LÉÉKO e do Laboratório de Decolonialidade em Ações e Investigações Artísticas LADAIA. E-mail: anapaulamelogeo@gmail.com

\section{Dayanne da Silva Santos}

Mulher Negra, ativista (defende o feminismo), periférica e de terreiro. Possui graduação em Ciências Sociais (2017) pela Universidade Federal do Maranhão é mestre em Ciências Sociais (2019), pela Universidade Federal do Maranhão, foi bolsista de iniciação científica da Fundação de Amparo à Pesquisa ao Desenvolvimento Científico e Tecnológico / PIBIC-FAPEMA; atualmente é doutoranda do Programa de Pós-Graduação em Sociologia pela Universidade Federal do Rio Grande do Sul (UFRGS). É integrante do Grupo de Estudos: Desenvolvimento, Modernidade e Meio Ambiente/GEDMMA, registrado do Diretório dos Grupos de Pesquisa do CNPq. Colabora com a Rede Justiça nos

\section{Denise Maria Botelho} Federal Rural de Pernambuco (UFRPE). Doutora em Educação e PósDoutoramento em Educação no Departamento de Educação da Universidade Federal da Paraíba (UFPB). Líder do Grupo de Estudos e Pesquisas em Educação, Raça, Gênero e Sexualidades Audre Lorde (Geperges Audre Lorde). E-mail: denise.botelho@ufrpe.br

\section{Gustavo Jaime Filizola}

Graduado em Letras pela Faculdade de Filosofia do Recife. Mestre em Educação, Culturas e Identidades (UFRPE/FUNDAJ). Doutorando em Educação (UFPE). de Estudos da Transdisciplinaridade, da Infância e da Juventude - GETIJ e do Grupo de Pesquisa Infância e Educação na Contemporaneidade - GPIEDUC. E-mail: filizola3@gmail.com

\section{Hendrix Silveira}

Bàbálórìsà da Comunidade Tradicional de Terreiro Ilé Àṣẹ Òrìsà Wúre. Doutor e Mestre em Teologia pelas Faculdades EST e Especialista em Ciências da Religião pela UCAM. Graduado em História pela FAPA. É Assessor Técnico do Conselho do Povo de Terreiro do Estado do Rio Grande do Sul e organizador e docente do curso de extensão universitária em Teologia das Tradições de Matriz Africana pela ESTEF. Pesquisador do Grupo de Pesquisa Identidade Étnica e Interculturalidade (EST). E-mail: hendrixsilveira@yahoo.com.br
Professora Associada do Departamento de Educação (DED) da Universidade Pesquisador do Núcleo de Estudo em Educação e Espiritualidade, do Grupo 


\section{Kaká Portilho}

Iyaraye de Sango do Île ni Oyo Oba Aganju, Neurocientista e Historiadora da Arte, professora de História Geral da África. Doutoranda em Antropologia Social, coordenadora do Centro de Altos Estudos e Pesquisas Afropindoramicas da UKAY e Instituto Hoju.

E-mail: ericaportilho@gmail.com

\section{Luciano Góes}

Iyawô, Doutorando em Direito pela Universidade de Brasília (UnB). Professor dos cursos de Pós-Graduação, especialização em Criminologia, do Instituto Brasileiro de Ciências Criminais (IBCCRIM) e Ciências Criminais (lato sensu) da Faculdade CESUSC. Integrante do Instituto Brasileiro de Criminologia Cultural. Advogado Abolicionista Afrocentrado.

E-mail: lucianogoesadvs@gmail.com

\section{Míriam Cristiane Alves}

Doutora em Psicologia pela Pontifícia Universidade Católica do Rio Grande do Sul (PUCRS), Professora Adjunta do Curso de Psicologia da Universidade Federal de Pelotas (UFPel), Professora Colaboradora do Programa de Pós Graduação em Psicologia Social e Institucional da Universidade Federal do Rio Grande do Sul (UFRGS). Coordenadora do Núcleo de Estudos e Pesquisa É'LÉÉKO.

E-mail: olorioba.miriamalves@gmail.com

\section{Monique Navarro}

Psicóloga pela Universidade Federal de Pelotas (UFPel). Mestranda em Psicologia Social e Institucional pela Universidade Federal do Rio Grande do Sul (UFRGS). Colaboradora do Núcleo de Estudos e Pesquisas É'LÉÉKO e do Núcleo de Ecologias e Políticas Cognitivas.

E-mail: moniquenavarro0410@gmail.com

\section{Nathan Vinicius Nascimento Lopes}

Pós-graduando em Direito Público no Instituto Damásio de Direito da Faculdade Ibmec SP. Bacharel em Direito pelo Centro Universitário Ruy Barbosa (UniRuy). Membro do grupo de pesquisa NUMPERR (Núcleo Multidisciplinar de Pesquisa e Extensão em Relações Raciais).

E-mail: ntnlopes.adv@gmail.com

\section{Olorode Ògìyàn Kálàfó Jayro Pereira de Jesus}

Afroativista do Instituto AfroAncestrálico Elésin Òsàgiyán/Ògiyán e coordenador geral da Escola Aldeia Ubuntu Vale do Akòko.

E-mail: escolaubuntuba@gmail.com

\section{Régia Mabel da Silva Freitas}

Doutora em Difusão do Conhecimento (Universidade Federal da Bahia-UFBA). Formadora Pedagógica decolonial. Pesquisadora, Palestrante e Organizadora de eventos, livros e periódicos acerca de epistemes negrorreferenciadas (Relações Raciais, com ênfase em Educação Antirracista, atuando em temas como Artes Negras, Culturas Africana e Afro-brasileira, Decolonialidade, Direito Antidiscriminatório e Feminismo Negro) numa perspectiva interseccional enucleando à raça as avenidas identitárias classe, crença, gênero, geração e orientação sexual. Coordenadora do Núcleo Multidisciplinar de Pesquisa e Extensão em Relações Raciais (NUMPERR). Membra do Núcleo de Pesquisas Afro-brasileiras em Artes, Tradições e Ensinagens na diáspora ALDEIA - da Universidade Federal do Sul da Bahia (UFSB).

E-mail: mabel_freitas@hotmail.com

\section{Valéria Fernandes de Carvalho}

Mestre em Educação pela Universidade Federal Fluminense (UFF). Professorapesquisadora da Escola Politécnica de Saúde Joaquim Venâncio (EPSJV)/ Fiocruz. Coordenadora do projeto SANKOFA: ensinamentos africanos, afrobrasileiros e indígenas na escola desenvolvido na EPSJV/Fiocruz.

E-mail: valfiocruz@gmail.com 


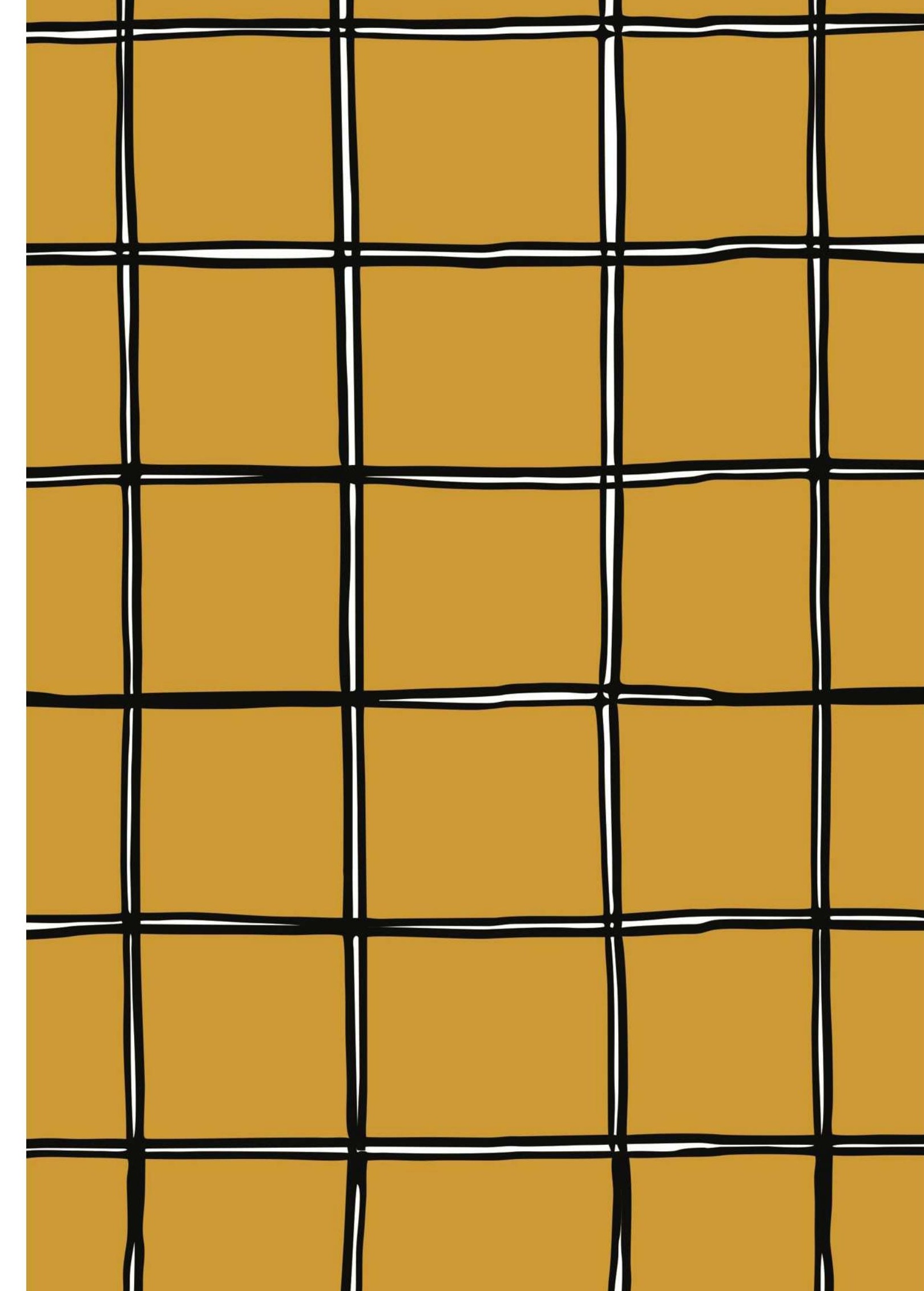


 \\ Publicações da Editora Rede UNIDA}

\section{Séries:}

Atenção Básica e Educação na Saúde

Micropolítica do Trabalho e o Cuidado em Saúde

Cadernos da Saúde Coletiva

Vivências em Educação na Saúde

Interlocuções Práticas, Experiências e Pesquisas em Saúde

Saúde Coletiva e Cooperação Internacional

Clássicos da Saúde Coletiva

Saúde \& Amazônia

Arte Popular, Cultura e Poesia

Branco Vivo

Saúde em imagens

Economia da Saúde e Desenvolvimento Econômico

Saúde, Ambiente e Interdisciplinaridade

Pensamento Negro Descolonial

\section{Outros}

\section{Periódicos:}

Revista Saúde em Redes

Revista Cadernos de Educação, Saúde e Fisioterapia

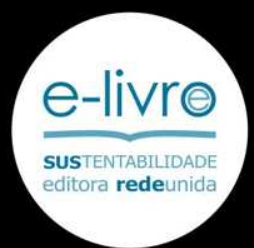

FAÇA SUA DOAÇÃO E COLABORE

www.redeunida.org.br
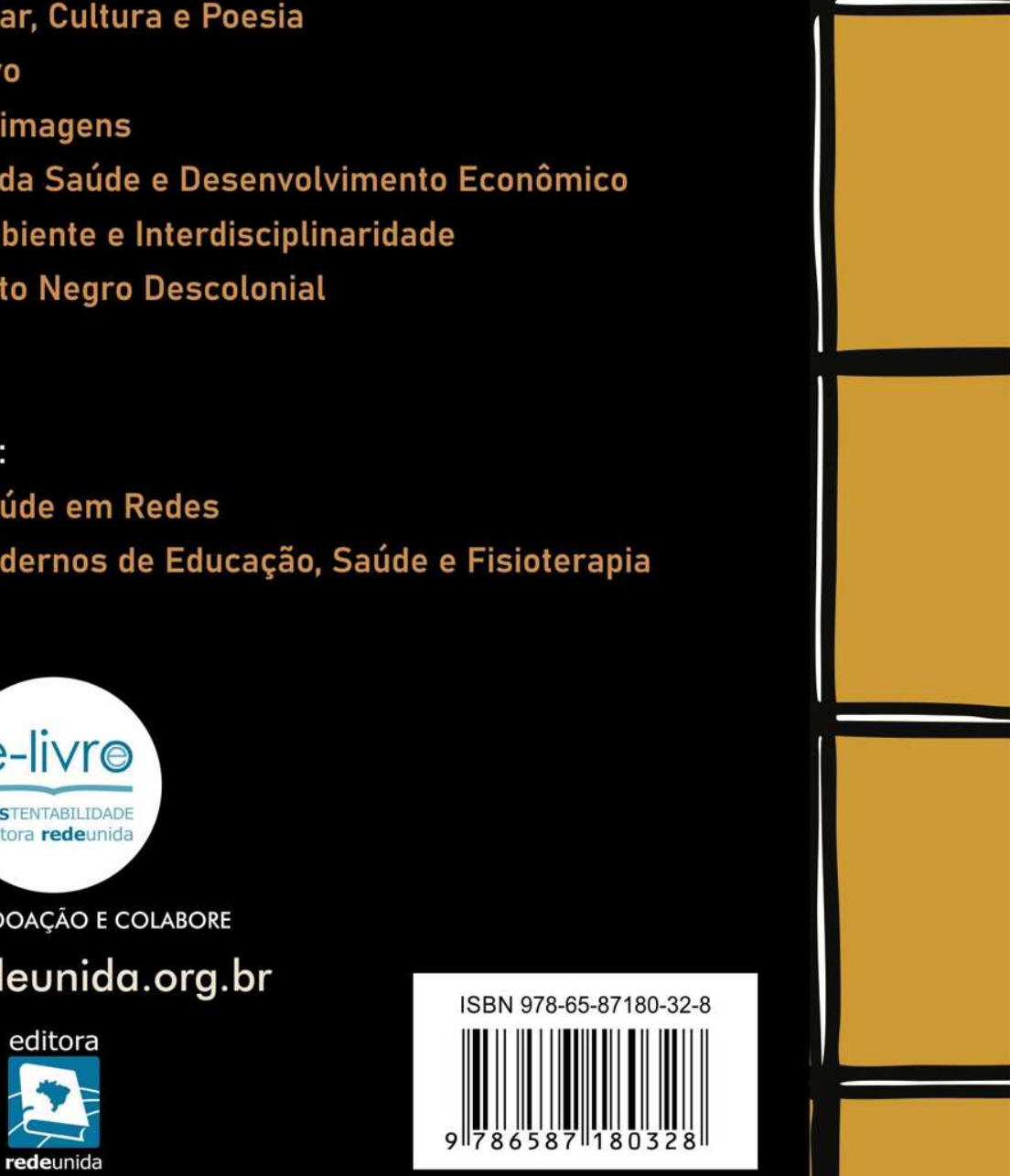